RAQUEL PAES DA ROCHA

\title{
A RESPOSTA SOS DE Caulobacter crescentus E RELAÇÕES DOS MECANISMOS DE REPARO COM A PROGRESSÃO DO CICLO CELULAR
}

Tese apresentada ao Programa de Pós-Graduação em Microbiologia do Instituto de Ciências Biomédicas da Universidade de São Paulo, para obtenção do título de Doutor em Ciências.

São Paulo

2011 
Raquel Paes da Rocha

A resposta SOS de Caulobacter crescentus e relações dos mecanismos de reparo com a progressão do ciclo celular

Tese apresentada ao Programa de Pós Graduação em Microbiologia do Instituto de Ciências Biomédicas da Universidade de São Paulo, para a obtenção de Título de Doutor em Ciências.

Área de concentração: Microbiologia

Orientação:

Prof. Dr. Carlos Frederico Martins Menck 
DADOS DE CATALOGAÇÃO NA PUBLICAÇÃO (CIP)

Serviço de Biblioteca e Informação Biomédica do

Instituto de Ciências Biomédicas da Universidade de São Paulo

(C) reprodução total

Rocha, Raquel Paes da.

A resposta SOS de Caulobacter crescentus e relação dos mecanismos de reparo de DNA com a progressão do ciclo celular I Raquel Paes da Rocha. -- São Paulo, 2011.

Orientador: Carlos Frederico Martins Menck.

Tese (Doutorado) - Universidade de São Paulo. Instituto de Ciências Biomédicas. Departamento de Microbiologia. Área de concentração: Microbiologia. Linha de pesquisa: Reparo de DNA em Caulobacter crescentus.

Versão do título para o inglês: The SOS response of Caulobacter crescentus and the relationship between DNA repair mechanisms and the cell cycle progression

Descritores: 1. Reparo de DNA 2. Ciclo celular 3. Caulobacter crescentus 4. Lesões do DNA 5. Genômica 6. Microbiologia I. Menck, Carlos Frederico Martins II. Universidade de São Paulo. Instituto de Ciências Biomédicas. Programa de Pós-Graduação em Microbiologia III. Título. 
Candidato(a):

Título da Tese:

Orientador(a):
Raquel Paes da Rocha.

A resposta SOS de Caulobacter crescentus e relação dos mecanismos de reparo de DNA com a progressão do ciclo celular.

A Comissão Julgadora dos trabalhos de Defesa da Tese de Doutorado, em sessão pública realizada a .................., considerou

\section{( ) Aprovado(a) \\ ( ) Reprovado(a)}

\begin{tabular}{|c|c|}
\hline Examinador(a): & $\begin{array}{l}\text { Assinatura: } \\
\text { Nome: ....... } \\
\text { Instituição: }\end{array}$ \\
\hline Examinador(a): & $\begin{array}{l}\text { Assinatura: } \\
\text { Nome: ........ } \\
\text { Instituição: }\end{array}$ \\
\hline Examinador(a): & $\begin{array}{l}\text { Assinatura: } \\
\text { Nome: ........ } \\
\text { Instituição: . }\end{array}$ \\
\hline Examinador(a): & $\begin{array}{l}\text { Assinatura: } \\
\text { Nome: ........ } \\
\text { Instituição: . }\end{array}$ \\
\hline Presidente: & $\begin{array}{l}\text { Assinatura: } \\
\text { Nome: ........ } \\
\text { Instituição: }\end{array}$ \\
\hline
\end{tabular}




\section{CERTIFICADO DE ISENÇÃO}

Certificamos que o Protocolo CEP-ICB $\mathrm{N}^{\circ} \mathbf{1 4 4}$, referente ao projeto intitulado "Caracterização funcional de genes relacionados a resposta sos e relação do reparo de DNA com a progressão celular em caulobacter crescentus ${ }^{6}$ sob a responsabilidade de Raquel Paes da Rocha, foi analisado na presente data pela CEEA - COMISSÃO DE ÉTICA EM EXPERIMENTAÇÃO ANIMAL e pela CEPSH - COMISSÃO DE ÉTICA EM PESQUISA COM SERES HUMANOS, tendo sido deliberado que o referido projeto não envolve manipulação animal ou humana que justifique uma aprovação quanto aos princípios éticos exigidos por ambas as Comissões.

São Paulo, 23 de março de 2006.

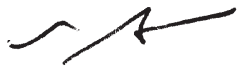

Prof. Dr. Marília C.L.SEELAENDER Coordenadora da CEEA - ICB/USP

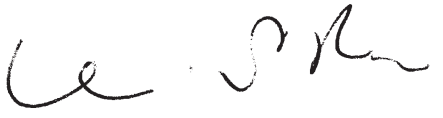

Prof. Dr. LUIZ VICENTE RIZZO Coordenador da CEPSH - ICB/USP 


\section{AGRADECIMENTOS}

Os agradecimentos são sempre difíceis de começar, mas vamos lá...

Antes de tudo, eu tenho que agradecer aos meus pais, por me proporcionarem a chance de chegar tão longe... Sem vocês, com certeza, nada disso aqui existiria! Obrigada pela força, pelo apoio, pela paciência, e principalmente pelo amor e pelo companheirismo!

Queria agradecer também a minha avó Ruth, que sempre esteve por perto! Me ajudando e cuidando de mim desde que eu me conheço por gente!

E por último (last but not least, claro), queria agradecer ao meu amor, Ponê! Obrigada pela paciência, pela confiança e por estar sempre lá por mim!

Ao Prof. Carlos Menck, pela possibilidade de fazer parte desse grupo tão maravilhoso! Por toda a ajuda, todo o conhecimento e todo apoio ao longo desses mais de cinco anos de aprendizado. Obrigada por me ensinar a sempre ver o melhor lado de tudo, e pela confiança em mim e no meu trabalho!

Ao Dr. Rodrigo Galhardo, pela paciência em me ensinar praticamente tudo que eu sei hoje! Sem você, realmente, essa tese não ia existir!

A Prof. Dra. Marilis Marques, pela ajuda, pelos conselhos e pela disponibilidade de sempre me ajudar com qualquer coisa!

Aos amigos de laboratório, aqueles com os quais eu não tenho mais contato diário e àqueles que ainda estão por aqui! Vocês com certeza tornaram o dia-a-dia muito melhor! E eu fico muito feliz de saber que eu tenho em vocês pessoas para chorar no ombro ou morrer de tanto dar risada! Alice, Apuã, Andrézão, Carol Berra, Carol Quayle, Dani, Helots, Kero, Leo, Lu A, Luis, Maria Helena, Marinas, Mel, Renatinha, Ric, Ste, Tati, Val... Se eu me esqueci de alguém, vocês estão autorizados a puxar a minha orelha! 


\section{RESUMO}

Rocha RP. A resposta SOS de Caulobacter crescentus e relação dos mecanismos de reparo de DNA com a progressão do ciclo celular. [Tese (Doutorado em Microbiologia)]. São Paulo: Instituto de Ciências Biomédicas da Universidade de São Paulo; 2011.

Caulobacter crescentus pertence ao grupo das proteobactérias alfa e apresenta uma característica distinta de diferenciação celular a cada ciclo de divisão, rara entre as bactérias. Estratégias que visem ao acoplamento entre o monitoramento da integridade do material genético, como mecanismos de reparo de DNA, e a progressão do ciclo celular devem, portanto, existir neste organismo. Estudos sobre mecanismos de reparo em bactérias sempre indicam como uma via importante àquela representada pela resposta SOS, uma complexa e ampla resposta celular frente a estresses genotóxicos. Dentro deste contexto, este trabalho visou aprofundar o conhecimento atual sobre os mecanismos de reparo em C. crescentus, bem como suas possíveis implicações para a progressão do ciclo celular. Caracterizamos a resposta SOS deste organismo através da construção de um mutante para o repressor desta, LexA. Neste trabalho identificamos 44 genes que são parte deste regulon. Vários destes coincidem com outras bactérias que já foram estudadas, mas muitos ainda não foram descritos como parte do regulon. Curiosamente, identificamos alguns genes (dnaB e a JAL CC_2433) que são regulados positivamente por LexA. Dedicamos também parte de nossos esforços para caracterizar funcionalmente alguns dos genes do regulon, como CC_2272 (que codifica uma proteína da família das endonucleases III) e CC_2433, descrito acima. A cepa deficiente em LexA apresentou morfologia filamentosa, e por esse motivo, buscamos também desvendar quais seriam os fatores genéticos responsáveis por esta morfologia; até o momento, no entanto, temos apenas uma hipótese de como a filamentação deva ocorrer na ausência de LexA. Neste trabalho também investigamos os processos de controle do ciclo celular após a introdução de danos na molécula de DNA pela luz UVC, em mutantes deficientes para diferentes vias de reparo. Estes experimentos nos mostraram que as células procariontes também possuem mecanismos para acoplar a progressão do ciclo celular a integridade do material genético, seja através de 
mecanismos canônicos de pontos de checagem (checkpoint) ou não. Este trabalho abre, portanto, novas e excitantes possibilidades no campo da biologia bacteriana.

Palavras-chave: Reparo de DNA. Ciclo celular. Caulobacter crescentus. Lesões ao DNA. Genômica. Microbiologia. 


\begin{abstract}
Rocha RP. The SOS response of Caulobacter crescentus and the relationship between DNA repair mechanisms and the cell cycle progression. [Ph. D. Thesis (Microbiology)]. São Paulo: Instituto de Ciências Biomédicas da Universidade de São Paulo; 2011.
\end{abstract}

Caulobacter crescentus, belonging to the group alphaproteobacteria, displays the distinctive feature of cell differentiation after each cell division, rare among bacteria. Several mechanisms of transcriptional and post-translation control are involved in ensuring the correct control and coordination of the process. Thus, strategies involved in monitoring the coupling of genetic material integrity, such as DNA repair mechanisms and cell-cycle-progression, must exist. Studies of these repair mechanisms in bacteria always indicate SOS response as being one of the most important, due to its complex and broad cellular response to genotoxic stress. In this context, the aim was to expand current knowledge on DNA repair mechanisms in C. crescentus, as well as the possible implications this could have on cell-cycle-progression. Thus, SOS response in this organism was characterized through the establishment of a mutant strain of its repressor, LexA. 44 genes that are part of the regulon were identified. Several are regulated in other bacteria, although some have not, as yet, been described as part of the regulon itself. Interestingly, certain genes ( $d n a B$ and the ORF CC_2433) that are up-regulated by LexA, were also identified. Part of our efforts were dedicated to functionally characterizing certain genes of this regulon, such as CC_2272, which encodes an endonuclease III family protein, and CC_2433, described above. An attempt was made to discover which of the genetic factors induced filamentous morphology in the LexA deficient strain. As yet, there is only a hypothesis of how this could possibly occur in the absence of LexA. Cell-cycle-control processes, following UVC induced DNA damage in mutant strains deficient in DNA repair pathways, were investigated. It was shown that prokaryotic cells also possess mechanisms for coupling cell-cycle-progression towards genetic material integrity, by way of canonical checkpoints or not. Thus, this work opens up new and exciting possibilities in the field of bacterial biology. 
Keywords: DNA Repair. Cell cycle. Caulobacter crescentus. DNA lesions. Genomics. Microbiology. 


\section{LISTA DE FIGURAS}

Figura 1 - Representação esquemática do ciclo celular de $C$. crescentus

Figura 2 - Diagrama esquemático da ativação da resposta SOS

Figura 3 - Esquema representativo da construção de mutantes pelo método de deleção em fase

Figura 4 - Esquema representativo das etapas de recombinação e seleções dos mutantes construídos com a utilização do vetor pNPTS138

Figura 5 - Esquema representativo da deleção e interrupção do operon CC_3038-CC_3037CC_3036 pelo cassete de resistência a espectinomicina 44

Figura 6 - Esquema representativo da interrupção do gene CC_3731 pelo cassete de resistência a espectinomicina 45

Figura 7 - Curvas de crescimento das cepas NA1000 e lexA 59

Figura 8 - A cepa lexA de C. crescentus possui fenótipo filamentoso 60

Figura 9 - Conteúdo de DNA das cepas NA1000 e lexA de C. crescentus 61

Figura 10 - Mutagênese sítio dirigida do promotor de imuA e análise da atividade dos promotores por ensaios de $\beta$-galactosidase 69

Figura 11 - Determinação do início de transcrição dos genes imuA e CC_2272 …...................... 70

Figura 12 - PCR diagnóstico confirmando a deleção do operon CC_3038-CC_3037-CC_3036 .... 72

Figura 13 - Análise microscópica das cepas NA1000, lexA, RM20 e RM30 de C. crescentus ....... 73

Figura 14 - Curvas de crescimento das cepas NA1000, lexA, RM20 e RM30 73 
Figura 15 - Sobrevivência das cepas NA1000, lexA, RM20 e RM30 frente à irradiação com luz UVC

Figura 16 - PCR diagnóstico confirmando a deleção do gene CC_0627 75

Figura 17 - Análise microscópica das cepas NA1000, lexA, CC_0627 e RM90 de C. crescentus .. 75 Figura 18 - Sobrevivência das cepas NA1000, lexA e CC_0627 frente à irradiação com luz UVC. 76 Figura 19 - Curvas de crescimento das cepas NA1000, lexA e CC_3225 77

Figura 20 - Sobrevivência das cepas NA1000, lexA e CC_3225 frente à irradiação com luz UVC 77

Figura 21 - Análise microscópica das cepas NA1000, lexA, CC_3225 e RM40 de C. crescentus .. 78 Figura 22 - Exemplo representativo do ensaio de natação realizado com C. crescentus para buscar um revertente do fenótipo não nadador 79

Figura 23 - Árvore filogenética de endonucleases III dos organismos selecionados 81

Figura 24 - PCR diagnóstico confirmando a deleção do gene CC_2272 82

Figura 25 - PCR diagnóstico confirmando a inativação do gene CC_3731 pela inserção do cassete de resistência a espectinomicina 83

Figura 26 - Análise microscópica das cepas NA1000, CC_2272, CC_3731 e RM70 de C. crescentus

Figura 27 - Curvas de crescimento das cepas NA1000, CC_2272 e CC_3731 84

Figura 28 - Sobrevivência das cepas NA1000, CC_2272, CC3731 e RM70 frente à irradiação com luz UVC 84

Figura 29 - Sobrevivência das cepas NA1000, CC_2272, CC3731 e RM70 frente ao tratamento com diferentes doses de $\mathrm{H}_{2} \mathrm{O}_{2}$ por 30 minutos 86 
Figura 30 - Sobrevivência da cepa NA1000 em tempos crescentes após a sincronização 90

Figura 31 - Sobrevivência das cepas NA1000, uvrA, uvrB e uvrC frente à irradiação com luz UVC

Figura 32 - Exemplos demonstrativos do perfil de progressão do ciclo celular da cepa NA1000 sincronizada e irradiada ou não com luz UVC

Figura 33 - Exemplos demonstrativos do perfil de progressão do ciclo celular da cepa uvrA sincronizada e irradiada ou não com luz UVC 94

Figura 34 - Exemplos demonstrativos do perfil de progressão do ciclo celular da cepa uvrB sincronizada e irradiada ou não com luz UVC 95

Figura 35 - Exemplos demonstrativos do perfil de progressão do ciclo celular da cepa uvrC sincronizada e irradiada ou não com luz UVC 96

Figura 36 - Exemplos demonstrativos do perfil de progressão do ciclo celular da cepa imuA sincronizada e irradiada ou não com luz UVC

Figura 37 - Exemplos demonstrativos do perfil de progressão do ciclo celular da cepa dnaE2 sincronizada e irradiada ou não com luz UVC 98

Figura 38 - Determinação do número de lesões CPD no DNAdo plasmídeo pCMUT após a irradiação com luz UVC 99

Figura 39 - Determinação imunológica das lesões CPDs presentes no DNA genômico de NA1000 sincronizada e irradiada com luz UVC 101

Figura 40 - Determinação imunológica das lesões CPDs presentes no plasmídeo pCMUT e no DNA genômico de uvrA sincronizada e irradiada com luz UVC 102

Figura 41 - Determinação imunológica das lesões CPDs presentes no plasmídeo pCMUT e no DNA genômico de uvrB sincronizada e irradiada com luz UVC 102 
Figura 42 - Determinação imunológica das lesões CPDs presentes no plasmídeo pCMUT e no DNA genômico de uvrC sincronizada e irradiada com luz UVC 103

Figura 43 - Determinação imunológica das lesões CPDs presentes no plasmídeo pCMUT e no DNA genômico de imuA sincronizada e irradiada com luz UVC 104

Figura 44 - Determinação imunológica das lesões CPDs presentes no plasmídeo pCMUT e no DNA genômico de dnaE2 sincronizada e irradiada com luz UVC 104

Figura 45 - Expressão do gene ctrA medida por RT-PCR quantitativo na cepa NA1000 em tempos crescentes após a sincronização e tratada ou não com luz UVC 106

Figura 46 - Expressão do gene ctrA medida por RT-PCR quantitativo na cepa uvrA em tempos crescentes após a sincronização e tratada ou não com luz UVC 107

Figura 47 - Sobrevivência das cepas NA1000 e uvrA frente à irradiação com $150 \mathrm{~J} / \mathrm{m}^{2}$ de luz UVC e seqüente fotorreativação (FR) com UVA (A) ou luz branca (B) 108

Figura 48 - Quantificação das lesões CPDs no DNA genômico de NA1000 e uvrA irradiadas com $150 \mathrm{~J} / \mathrm{m}^{2}$ de luz UVC e fotorreativadas com luz UVA ou luz branca 109

Figura 49 - Exemplos demonstrativos do perfil de progressão do ciclo celular da cepa NA1000 sincronizada, irradiada ou não com luz UVC e fotorreativada ou não 110

Figura 50 - Exemplos demonstrativos do perfil de progressão do ciclo celular da cepa uvrA sincronizada, irradiada ou não com luz UVC e fotorreativada ou não

Figura 51 - Expressão do gene ctrA medida por RT-PCR quantitativo na cepa NA1000 em tempos crescentes após a sincronização, tratamento ou não com luz UVC e fotorreativação ou não com luz UVA 


\section{LISTA DE TABELAS}

Tabela 1 - DNA glicosilases anotadas no genoma de E. coli

Tabela 2 - DNA glicosilases anotadas no genoma de $C$. crescentus 24

Tabela 3 - Genes pertencentes ao regulon SOS de $E$. coli e com função conhecida 29

Tabela 4 - Unidades de $\beta$-galactosidase obtidas a partir do promotor do gene rho nas cepas NA1000 e lexA 62

Tabela 5 - Genes identificados pela análise in silico como sendo parte do regulon SOS em $C$. crescentus e comparação da expressão in vivo destes genes na cepa NA1000 e lexA - primeira avaliação 63

Tabela 6 - Genes adicionais identificados pela análise in silico como sendo parte do regulon SOS em C. crescentus e comparação da expressão in vivo destes genes nas cepas NA1000 e lexA ... 67

Tabela 7 - Freqüência de mutação espontânea das cepas NA1000, CC_2272 e CC_3731 85

Tabela 8 - Expressão relativa dos genes CC_2433 e dnaB (CC_1665) nas cepas CC_3225, RM20 e lexA em comparação com a cepa selvagem NA1000

Tabela 9 - Unidades de $\beta$-galactosidase obtidas a partir do promotor do gene rho nas cepas NA1000, RM20 e CC_3225 87

Tabela 10 - Análise comparativa dos genes pertencentes ao regulon SOS 115 


\section{LISTA DE ABREVIATURAS E SIGLAS}

6-4 PP: 6-4 pirimidina-pirimidona fotoprodutos

8-oxodG: 7,8-dihidro-8-oxiguanina

aa: Aminoácidos

Anti-CPD: anticorpo primário específico para lesões de DNA CPD

AP: Sítio apurínico ou apirimidínico, do inglês Apurinic or apyrimidinic site

BER: Reparo por excisão de bases, do inglês Base excision repair

BSA: Albumina bovina sérica, do inglês Bovine serum albumin

cDNA: DNA complementar

CPD: Dímeros de pirimidina ciclobutanos, do inglês Cyclobutane pyrimidine dimers

D.O.: Densidade ótica

DEPC: Dietilpirocarbonato

DMSO: dimetilsulfóxido

DTT: Ditiotreitol

EDTA: Ácido etilenodiamino tetra-acético

FADH-: forma reduzida da flavina adenina dinucleotídeo

FCM: Citometria de fluxo, do inglês Flow Cytometry

FMN: 8-hidroxi-5-desaflavina 
HRP: Peroxidase

JAL: Janela aberta de leitura

LB: Meio de Luria-Bertani

M2G: Meio mínimo para C. crescentus M2 acrescido de 0,2 \% de glicose

MTHF: metenil tetrahidrofolato

NER: Reparo por excisão de nucleotídeo, do inglês Nucleotide excision repair

ONPG: O-nitrofenil $\beta$-D-galactopiramisídeo

PBS: Tampão fosfato salino, do inglês Phosphate Buffer Solution

PCR: Reação de polimerização em cadeia, do inglês Polimerization chain reaction

PYE: Meio de peptona e extrato de levedura para $C$. crescentus, do inglês Peptone yeast extract

RT-PCR: Reação de polimerização em cadeia reversa, do inglês Reverse transcription polimerization chain reaction

SDS: Dodecil sulfato de sódio, do inglês Sodium dodecyl sulfate

SOB: Meio de cultura para E. coli rico em fontes de carbono, do inglês Super Optimal Broth

SOC: Meio de cultura para E. coli SOB acrescido de $20 \mathrm{mM}$ de glicose, do inglês Super Optimal Broth with Catabolite repressor

TBE: Tampão Tris-Borato 89 mM e 2 mM EDTA

TE: Tampão Tris EDTA

TLS: Síntese translesão, do inglês Translesion synthesis

UV: radiação ultravioleta 


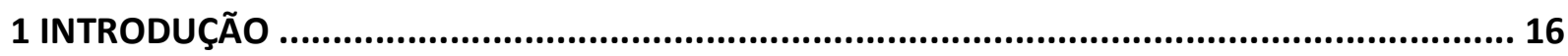

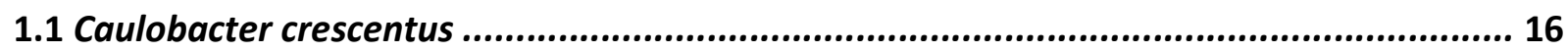

1.2 Integridade do material genético .......................................................................... 19

1.3 Reparo Direto - As fotoliases ........................................................................................ 20

1.4 Reparo por Excisão ..................................................................................................... 21

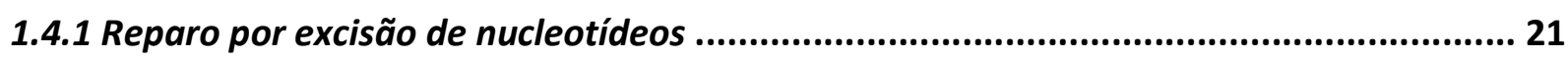

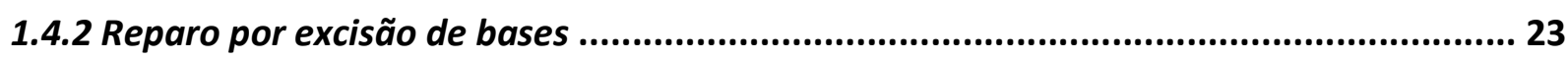

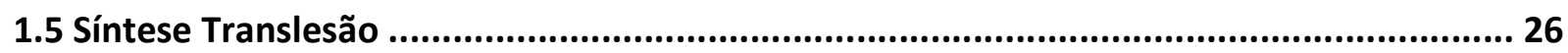

1.6 Resposta SOS: coordenando os esforços .................................................................. 27

1.7 Checkpoints em células procariontes: verdade ou mito? ................................................... 31

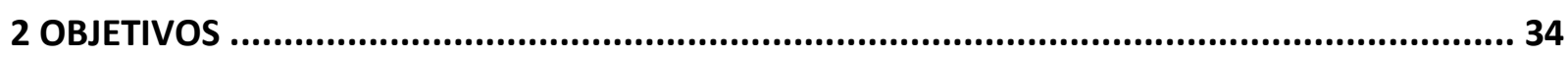

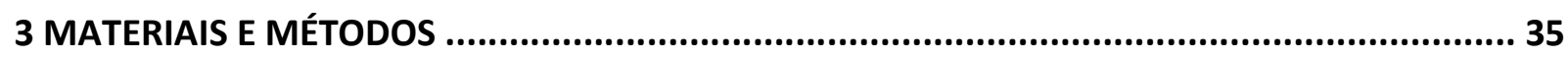

3.1 Manutenção e cultivo de cepas de C. crescentus .............................................................. 35

3.2 Manutenção e cultivo de cepas de E. coli ...................................................................... 35

3.3 Obtenção de bactérias competentes ............................................................................. 36

3.4 Transformação bacteriana …………………………….................................................. 36

3.5 Preparação de DNA plasmidial ....................................................................................... 37

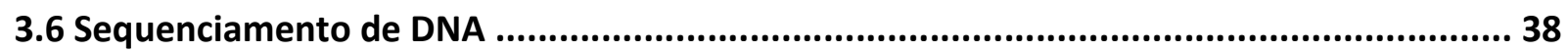

3.7 Irradiações com luz UVC ...................................................................................... 39

3.8 Microscopia .................................................................................................................. 39

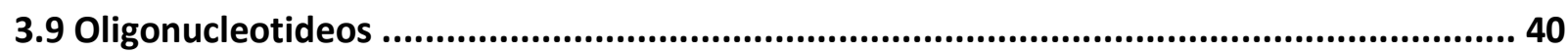

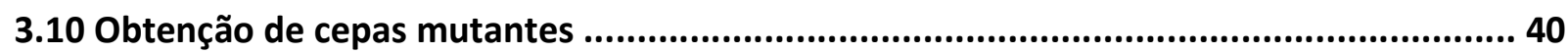

3.10.1 Obtenção de cepas mutantes pelo método de deleção em fase .................................... 40

3.10.2 Obtenção de cepas mutantes pelo método da deleção em fase e inserção de cassete de resistência a espectinomicina ................................................................................................. 43

3.10.3 Obtenção de cepas mutantes pela interrupção da região codificante pelo cassete de resistência a espectinomicina .................................................................................................. 44

3.11 Complementação do mutante lexA ................................................................................. 46 
3.12 Ensaios de crescimento 46

3.13 Extração de DNA genômico de $C$. crescentus ............................................................... 46

3.14 Conjugação de cepas de $C$. crescentus com E. coli S17-1 contendo o promotor do gene rho

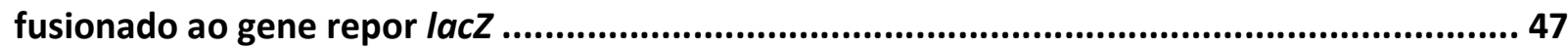

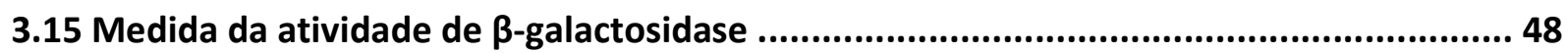

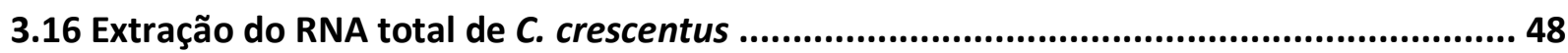

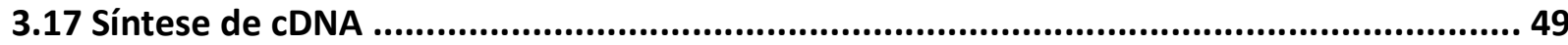

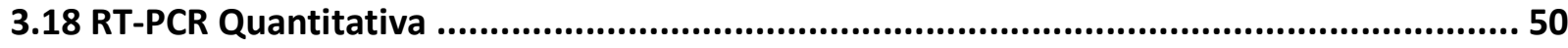

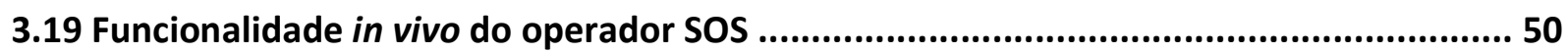

3.19.1 Mutagênese sítio dirigida do promotor de imuA .................................................... 50

3.19.2 Medida da atividade de 6-galactosidase .................................................................... 51

3.19.3 Determinação do início de transcrição dos genes imuA e CC_2272 ........................... 51

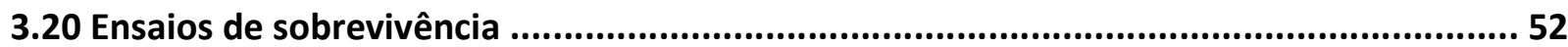

3.21 Mutagênese aleatória da cepa lexA .......................................................................... 52

3.21.1 Mutagênese aleatória da cepa lexA utilizando o transposon Mariner ......................... 52

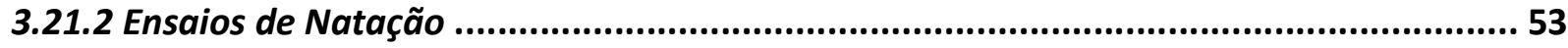

3.22 Determinação da freqüência de mutação espontânea ................................................ 53

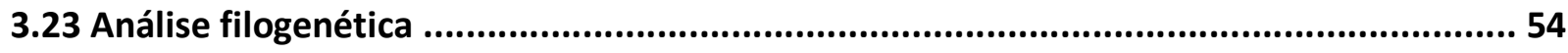

3.24 Sincronização de culturas de $C$. crescentus .................................................................... 54

3.25 Avaliação do ciclo celular através de citometria de fluxo .............................................. 55

3.26 Determinação e quantificação de lesões CPD em DNAs genômicos de C. crescentus ...... 56

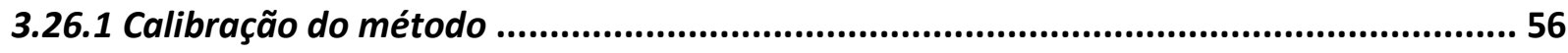

3.26.2 Quantificação de lesões CPD através de ensaios de relaxamento de plasmídeos ........ 56

3.26.3 Deteç̧ão de lesões CPD por ensaios de imuno slot-blot ............................................. 57

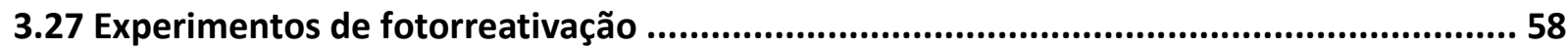

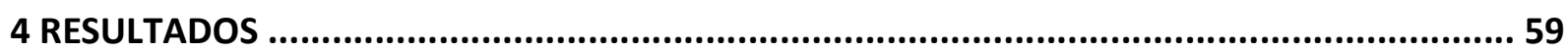

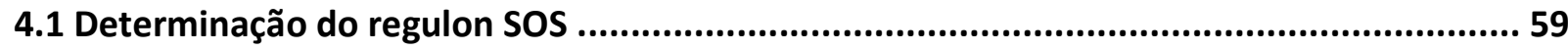

4.1.1 Identificação dos genes regulados por LexA ............................................................. 59

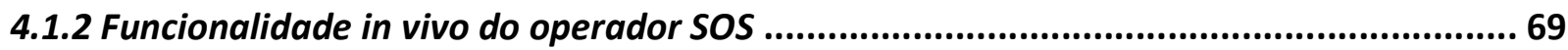


4.2 Procura pelo gene responsável pelo bloqueio da divisão celular no mutante lexA

4.3 Análise funcional de genes pertencentes ao regulon SOS

4.3.1 CC_2272, membro da família das endonucleases III 80

4.3.2 CC_2433 e dnaB, genes possivelmente positivamente regulados por LexA 86

4.4 Relações entre danos e reparo de DNA e ciclo celular em $C$. crescentus 89

5 DISCUSSÃO 113

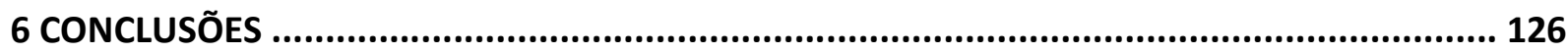

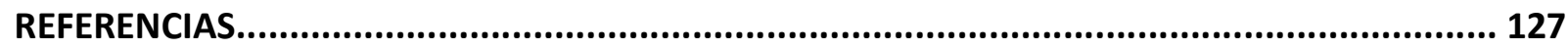

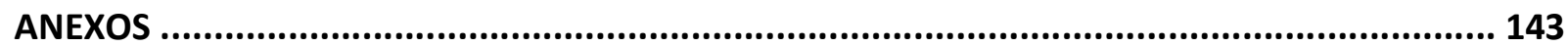

ANEXO A - Oligonucletídeos utilizados neste trabalho .................................................. 144

ANEXO B - Artigo Científico publicado na revista Journal of Bacteriology, fev. 2008 ........... 156 


\section{INTRODUÇÃO}

\subsection{Caulobacter crescentus}

C. crescentus é uma proteobactéria da subdivisão alfa (portanto, uma gram-negativa) de vida livre. Bactérias do gênero Caulobacter se encontram distribuídas nos mais variados ambientes, como aqueles altamente ricos em nutrientes (MacRae e Smit, 1991), tóxicos como minas de ouro (Inagaki et al., 2003) e água e solos contaminados (Mannisto et al., 1999; North et al., 2004); elas são, no entanto, mais conhecidas por habitarem ambientes aquáticos pobres em nutrientes. Os primeiros isolados de C. crescentus datam de 1964 (Poindexter, 1964), e desde então, muitos esforços foram realizados para entender as adaptações e mecanismos de regulação deste organismo frente ao ambiente que o cerca. Talvez uma das características mais interessante e estudada em $C$. crescentus é a presença nesta de um ciclo celular dimórfico. A cada ciclo celular, $C$. crescentus produz duas progênies diferentes não apenas morfologicamente, mas também fisiologicamente: uma célula móvel, a forma dispersiva, e uma célula talo, séssil.

A célula talo é totalmente competente para a replicação do material genético, iniciando este processo tão logo é produzida. Já a célula móvel se encontra em fase présintética G1, sendo incapaz de replicar seu DNA logo após a divisão celular; para que isso ocorra, a célula móvel deve passar por uma série de alterações, tornando-se uma célula talo. Inicialmente ela perde seu único flagelo polar, e em seu lugar se desenvolve uma extensão do envelope celular denominada talo; na ponta desta estrutura existe uma organela adesiva, que é responsável pela aderência da célula talo a superfícies. Esta alteração morfológica também desencadeia mudanças fisiológicas extensas, que serão descritas a seguir. Ao se tornar uma célula talo, ela é então capaz de replicar o DNA (fase S) e prosseguir em seu plano de desenvolvimento. Conforme a célula talo duplica seu DNA, ela também se alonga dando origem ao tipo celular denominado pré-divisional. Uma célula pré-divisional em estágio avançado (fase G2) já apresenta uma constrição em sua região central, sendo que 
um novo flagelo começa a ser sintetizado no pólo oposto ao do talo. Uma divisão celular dá origem então novamente a uma célula móvel e outra séssil (Figura 1).

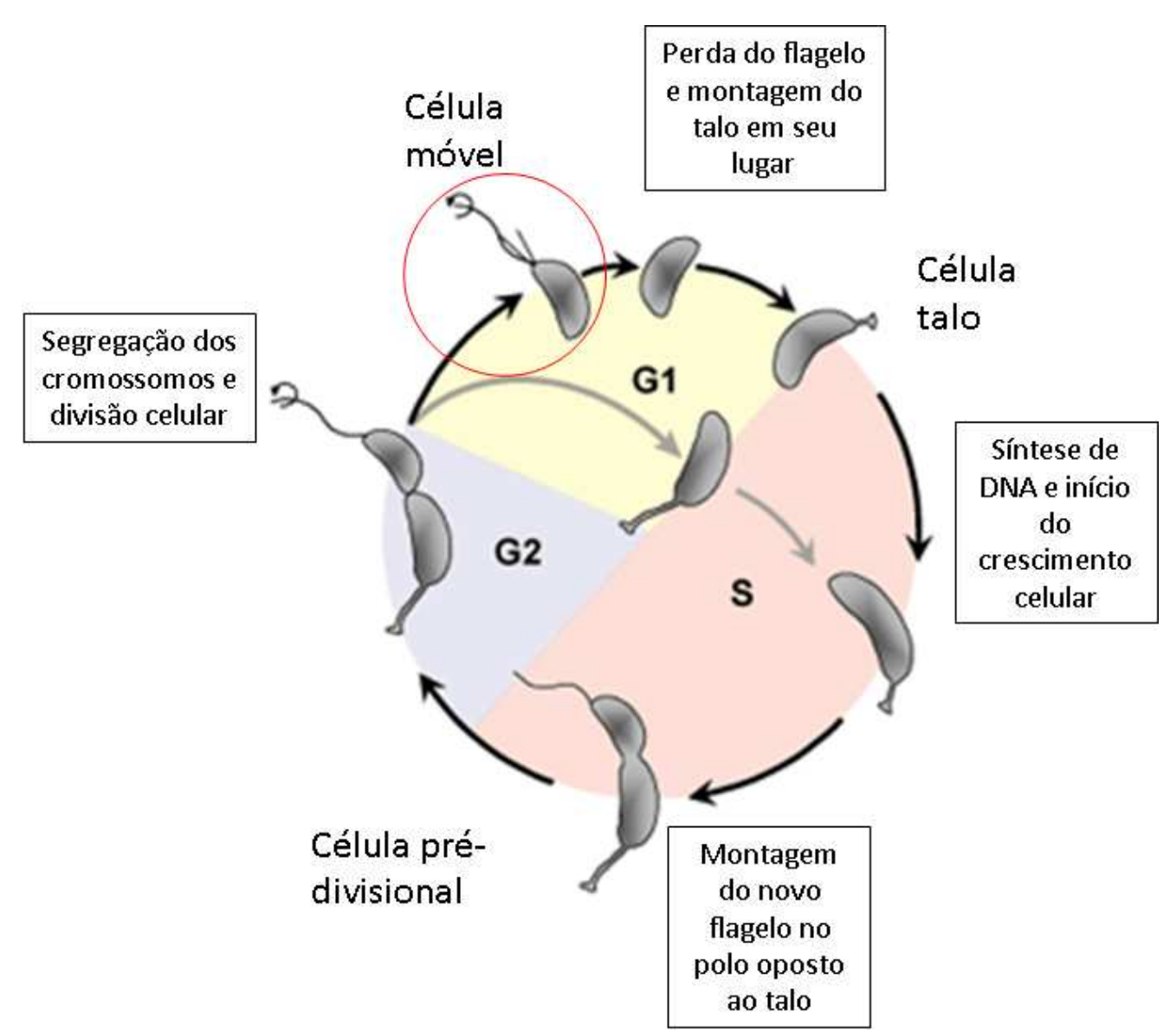

Figura 1 - Representação esquemática do ciclo celular de $C$. crescentus. Os diferentes tipos celulares estão indicados, bem como os eventos morfológicos mais importantes $e$ característicos de cada transição (indicados nos quadrados pretos). O círculo vermelho indica o tipo celular coletado no processo de sincronização celular. Demais detalhes se encontram no texto.

Fonte: University of Yale, Jacobs-Wagner Lab (2007).www.yale.edu/jacobswagner/images/cell_cycle.gif.

As alterações morfológicas, pelas quais passa C. crescentus, são acompanhadas por grandes mudanças na transcrição de genes, síntese e localização de proteínas. Uma família de proteínas importantes para estes processos é a dos sistemas de dois componentes de transdução de sinal. Eles são importantes para a regulação da expressão gênica dos procariontes frente a estímulos externos ou internos. Tipicamente, a transdução do sinal se inicia com uma histidina quinase, que se auto-fosforila em um resíduo conservado de histidina em resposta a um determinado estímulo. Esta fosfo-histidina é então capaz de 
fosforilar um resíduo de aspartato em seu regulador de resposta cognato, sendo este o responsável por promover a resposta celular adequada (Pirrung, 1999). Muitos reguladores de resposta são capazes de se associar ao DNA, ativando ou reprimindo a expressão de genes alvo. Alternativamente, podem existir histidinas quinase híbridas, que contém domínios sensores e efetores; estas estão em geral envolvidas em complexas e extensas vias de transmissão de fosfato, produzindo respostas amplas no organismo em questão.

No caso de $C$. crescentus, uma das proteínas centrais na regulação e coordenação da progressão do ciclo celular é o regulador de resposta essencial CtrA (Quon et al., 1996). Esta proteína possui um domínio de ligação a DNA, cuja afinidade por promotores alvos é aumentada na forma fosforilada; esta, então, é capaz de atuar como ativador ou repressor da expressão de um grande número de genes durante o ciclo celular. Cerca de $20 \%$ dos genes de $C$. crescentus possui alguma forma de regulação transcricional dependente do ciclo celular, sendo que $26 \%$ destes têm sua expressão dependente indireta ou diretamente de CtrA (Laub et al., 2000). Experimentos de imunoprecipitação de cromossomo indicaram que cinqüenta e cinco genes são parte do regulon de CtrA, sendo diretamente regulados por ele e participando de processos tão diversos quanto biossíntese do flagelo, biossíntese de pili e aparato quimiotático e divisão celular (Laub et al., 2002). É de se esperar, portanto, que uma proteína tão importante ao desenvolvimento seja objeto de diversos níveis de controle; no que se refere à CtrA existem pelo menos três níveis, o transcricional, a proteólise e a fosforilação (Curtis e Brun, 2010).

Como mencionado, a forma fosforilada de CtrA é a forma ativa. Na célula móvel, CtrA P se liga a cinco regiões na origem de replicação cromossomal, sendo responsável pela inibição da replicação do DNA. A primeira grande modificação que deve acontecer na transição entre as fases móvel e séssil é, portanto, a eliminação de CtrA. Isso ocorre através da degradação mediada pela protease dependente de ATP ClpXP (Jenal e Fuchs, 1998). Quase coincidentemente com a sua degradação, CtrA começa a ser transcrito (Domian, 1999) e é novamente fosforilado. Após a formação do septo de divisão na célula prédivisional, ocorre a degradação de CtrA em seu compartimento séssil (Judd, 2003), ficando garantida, dessa forma, a inibição da replicação na célula móvel nascente e o contrário na célula talo. 
Existem hoje poucos trabalhos focando mecanismos de reparo de DNA em $C$. crescentus. O primeiro relato em literatura foi realizado por Bender (1984). Neste trabalho ele descreve a existência provável de resposta SOS neste organismo através da reativação de bacteriófagos em bactérias irradiadas com 5 e $10 \mathrm{~J} / \mathrm{m}^{2}$ de luz ultravioleta (UV). Outro trabalho descreve um mutante para o gene alkB de C. crescentus (Colombi e Gomes, 1997), que é altamente sensível ao tratamento com metil metanosulfonado (MMS); este gene foi posteriormente demonstrado como pertencente a uma nova via de reparo, a demetilação oxidativa (Falnes et al., 2002). Além destes, os trabalhos realizados em nosso laboratório renderam três artigos que contribuíram significativamente para a compreensão dos mecanismos de reparo em C. crescentus (Galhardo et al., 2005; Martins-Pinheiro et al., 2007; Rocha et al., 2008).

Apesar da complexa regulação do desenvolvimento e progressão do ciclo celular nesta bactéria, as relações entre ciclo celular, danos ao DNA e reparo destes ainda são pouco conhecidas em Caulobacter e mesmo nas bactérias em geral. Esperamos com este trabalho, portanto, auxiliar na expansão do conhecimento neste campo.

\subsection{Integridade do material genético}

A manutenção da integridade do material genético é essencial para a sobrevivência dos organismos e a correta transmissão de informações para as gerações seguintes. O DNA é sujeito em todos os momentos a diversos tipos de agentes endógenos e exógenos capazes de induzir danos em sua molécula. A persistência de danos no DNA pode levar ao estabelecimento de mutações que, apesar de serem neutras em sua maioria, podem ter efeitos deletérios para a célula e o organismo. Além disso, danos não corrigidos ainda podem induzir parada do ciclo e morte celular, além de processos mais importantes para organismos multicelulares, como o surgimento de câncer (Van Steeg e Kramer, 1996). A existência, portanto, de mecanismos dedicados exclusivamente a sua verificação e reparo é de vital importância. Diferentes lesões são em geral reparadas por diferentes vias, podendo ainda ocorrer sobreposição de função entre as proteínas (Friedberg et al., 2006). As 
próximas linhas se dedicarão a descrever as vias de reparo de DNA que serão mencionadas neste trabalho. É importante destacar que elas são apenas uma faceta dos mecanismos de defesa das células para lidar com danos a seu material genético.

\subsection{Reparo Direto - As fotoliases}

A luz solar é uma fonte de danos ao DNA muito importante para todos os seres vivos, principalmente por causa dos comprimentos de onda correspondentes a luz UV. Nossa atmosfera é responsável por bloquear totalmente o componente UVC (100 a $280 \mathrm{~nm}$ ), deixando chegar ao solo UVB (280 a $315 \mathrm{~nm}$ ) e UVA (315 a $400 \mathrm{~nm}$ ) (Kuluncsics, 1999). Os principais tipos de lesão gerados pela irradiação de células com luz UV de baixo comprimento (UVC e UVB) são os dímeros de pirimidina ciclobutanos (CPDs, do inglês cyclobutane pyrimidine dimers) e os fotoprodutos 6-4 pirimidinas-pirimidonas (6-4 PP) (Friedberg et al., 2006), formados pela ligação covalente entre duas pirimidinas adjacentes. Ambos fotoprodutos são capazes de prejudicar a replicação e transcrição do DNA, com efeitos potencialmente letais para as células (revisto por Moriwaki e Takahashi, 2008). Por esse motivo, existem alguns mecanismos dedicados a remover estas lesões; um dos mais importantes é o reparo direto por fotorreativação enzimática, mediado por uma enzima denominada fotoliase (Friedberg et al., 2006). Esta enzima é capaz de desfazer a ligação entre as duas pirimidinas adjacentes da lesão em uma reação dependente de luz. Na natureza existem dois tipos de fotoliase, que são específicas para cada um dos tipos de dímero de pirimidina: CPDs fotoliases e 6-4 PP fotoliases. As primeiras estão presentes em quase todos os organismos, com exceção dos mamíferos placentários; já a segunda tem uma distribuição muito mais restrita, tendo sido identificada até agora apenas em Drosophila, alguns vertebrados e plantas (Todo, 1999). Por este motivo, neste trabalho discutiremos apenas as CPDs fotoliases.

As fotoliases, via de regra, possuem dois cromóforos; o primeiro, o cofator catalítico e comum a todas, é o FADH-. O segundo, chamado do foto-antena, pode ser metenil tetrahidrofolato (MTHF), presente na maioria delas, ou 8-hidroxi-5-desaflavina (FMN). 0 
segundo cromóforo é responsável pela absorção do fóton de luz, sendo este transferido para o primeiro cromóforo; ele doa um elétron ao CPD, que é então monomerizado (Sancar e Sancar, 1987).

C. crescentus possui pelo menos dois genes pertencentes à família das fotoliases, CC_1428 (phr, fotoliase típica) e CC_0646 (Martins-Pinheiro et al., 2007). Além disso, identificamos outros genes com domínio do fotoliase, CC_1330 e CC_2332, como parte do regulon SOS deste organismo (Rocha et al., 2008). A proteína codificada por CC_1428 foi purificada e demonstrou-se que ela realmente é uma fotoliase que contém MTHF como segundo cromóforo, capaz de remover dímeros CPD, mas não 6-4 PP (Öztürk et al., 2008).

\subsection{Reparo por Excisão}

\subsubsection{Reparo por excisão de nucleotídeos}

Existe outro sistema responsável pela remoção dos adutos de pirimidina da molécula de DNA. O tipo de reparo conhecido como reparo por excisão de nucleotídeos (NER, do inglês nucleotide excision repair) é capaz de remover estas e outras lesões distorcivas a dupla hélice.

O NER em bactérias tem essencialmente cinco etapas: o reconhecimento e verificação do dano, a incisão da fita do DNA afetado em ambos os lados a partir da lesão e excisão do oligonucleotídeo contendo o dano, a ressíntese do fragmento, e sua ligação a fita de DNA original (Friedberg et al., 2006). A descoberta de mutantes para os genes que participam deste processo em E. coli datam da década de 60 (Howard-Flanders e Boyce, 1966).

O reconhecimento da lesão é realizado pelas proteínas UvrA e UvrB associadas como

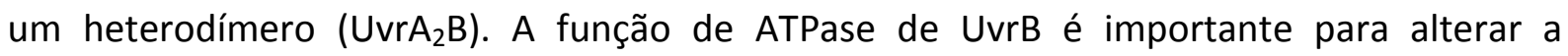
conformação do DNA na região da lesão facilitando o reconhecimento desta pela endonuclease UvrC. UvrA é removida do sítio da lesão e UvrC realiza uma incisão quatro 
ligações fosfodiéster a 3' da lesão e outra incisão oito ligações a 5' desta. A helicase UvrD retira então retira o fragmento de DNA de doze nucleotídeos que contem a lesão; a enzima DNA polimerase I retira UvrB e ressintetiza o fragmento de DNA, que é religado ao DNA original pela DNA ligase I (revisto por Van Houten et al., 2005).

Os genes de NER em $E$. coli estão presentes tipicamente em baixos níveis na célula (UvrA: 20 a 25 moléculas por célula e UvrB: 250 moléculas por célula), sendo a expressão de alguns deles induzida mais de dez vezes após o surgimento de danos na molécula de DNA (revisto por Van Houten et al., 2005). Em E. coli, uvrA e uvrB fazem parte do regulon SOS (Courcelle, 2001); nosso trabalho descrevendo o regulon SOS de $C$. crescentus demonstrou que neste organismo, apenas uvrA está sob controle de LexA, como será discutido adiante (Rocha et al., 2008).

A gama de lesões reconhecidas pelo sistema UvrABC é muito grande, e inclui desde modificações de uma única base (como as mediadas por aflatoxina B1 (Alekseyev et al., 2004) e psoralenos (Ramaswamy e Yeung, 1994), ligações cruzadas (os crosslinks) inter e intra cadeias (mediados, por exemplo, por cisplatina (Chaney et al., 2004) e mitomicina C (Howard-Flanders e Boyce, 1966), além de luz UV)) e intercalantes de DNA, como a doxorrubicina (Anderson et al., 1993). A regra geral parece ser que, quanto maior o aduto ou mais distorciva a lesão, melhor é sua eficiência de remoção pelo NER de E. coli (revisto por Van Houten et al., 2005).

Mutantes para todos os genes pertencentes a esta via de reparo de $E$. coli já foram identificados, e a característica comum entre eles é a extrema sensibilidade a irradiação com luz UV (Bagg et al., 1981; Howard-Flanders e Boyce, 1966). Um estudo prévio em nosso laboratório identificou mutantes para alguns genes de NER de C. crescentus através da seleção de clones de uma biblioteca construída com a inserção aleatória do transposon Tn5, que se mostraram sensíveis à irradiação com luz UVB (Marques, 2008). Estes mutantes foram então utilizados neste trabalho para a análise das relações entre danos a molécula de DNA e a progressão do ciclo celular em $C$. crescentus. 


\subsubsection{Reparo por excisão de bases}

A via de reparo provavelmente mais utilizada na natureza é a de reparo por excisão de bases (BER, do inglês, base excision repair). Esta também é a via com a maior variedade de proteínas envolvidas, além da existência de muitos níveis de sobreposição entre suas funções. A principal diferença entre este tipo de reparo por excisão em relação ao NER é que aqui apenas a base afetada é removida, através da catálise da ligação glicosídica entre esta e o esqueleto de desoxirribose-fosfato do DNA (Friedberg et al., 2006).

Enzimas da classe da família das DNA glicosilases, específicas no reconhecimento de determinados tipos de bases modificadas ou inapropriadas, são responsáveis por iniciar este tipo de reparo. Este evento gera um sítio abásico na molécula de DNA (sítios AP, de sítios apurínicos ou apirimidínicos), que é removido por uma segunda classe de enzimas, as AP endonucleases. Estas enzimas também são responsáveis pela remoção de sítios AP resultantes de eventos espontâneos; elas clivam a ligação fosfodiéster imediatamente a 5' do sitio abásico. O resíduo 5' terminal desoxirribose-fosfato gerado após a ação da enzima é removido pelas DNA-desoxiribofosfatodiesterase (dRpases), sendo o novo nucleotídeo sintetizado e ligado ao DNA original pela ação da DNA polimerase I e DNA ligase I, respectivamente (Friedberg et al., 2006).

A maior variedade de proteínas que realiza este tipo de reparo se concentra na classe das DNAs glicosilases. Cada uma destas enzimas é capaz de reconhecer apenas um pequeno grupo de lesões, bases modificadas ou incorretamente emparelhadas / incorporadas. Além da classificação no que se refere ao tipo de lesão reconhecida, ainda podemos classificar as DNA glicosilases pela presença ou não de atividade de AP endonuclease conjugada (Friedberg et al., 2006).

E. coli possui, ao todo, oito DNA glicosilases descritas. Uma breve descrição de suas especificidades se encontra na tabela 1. 
Tabela 1 - DNA glicosilases anotadas no genoma de E. coli.

\begin{tabular}{lll}
\hline Gene & Nome & Alvos \\
\hline ung & Uracila-DNA glicosilase & Uracilas do DNA \\
$f p g$ & Formamidopirimidina DNA & Purinas oxidadas e com anel purínico \\
& glicosilase & aberto \\
mutY & Adenina glicosilase & Adeninas opostas a 8-oxodG \\
$n t h$ & Endonuclease III & Pirimidinas oxidadas \\
tagA & 3-Metiladenina DNA glicosilase I & 3-metiladeninas e 3-etiladeninas \\
alkA & 3-Metiladenina DNA glicosilase II & Metil e etilpurinas \\
$n e i$ & Endonuclease VIII & Pirimidinas oxidadas e fragmentadas \\
$x t h A$ & Exodeoxirribonuclease III & Sítios Abásicos (apresenta também \\
& & atividade de AP-endonuclease) \\
\hline
\end{tabular}

Fonte: Friedberg et al., 2006.

A análise do genoma de $C$. crescentus revelou a presença de quase todas as glicosilases descritas em E. coli, algumas com mais de um ortólogo; a mais notável ausência é a da endonuclease VIII, codificada em E. coli pelo gene nei (tabela 2).

Tabela 2 - DNA glicosilases anotadas no genoma de C. crescentus. JALs em negrito e sublinhadas: reguladas por LexA em C. crescentus.

(Continua)

\begin{tabular}{lll}
\hline Gene & JAL (s) & Nome \\
\hline ung & CC_2084 & Uracila-DNA glicosilase \\
& CC_1333 & \\
& CC 2333 & \\
& CC_1549 & \\
fpg & CC_3707 & Formamidopirimidina DNA glicosilase \\
mutY & CC_0377 & Adenina glicosilase \\
nth & $\underline{\text { CC 2272 }}$ & Endonuclease III \\
& CC_3731 & \\
tagA & CC $\mathbf{0 3 8 2}$ & 3-Metiladenina DNA glicosilase I
\end{tabular}


Tabela 2 - DNA glicosilases anotadas no genoma de C. crescentus. JALs em negrito e sublinhadas: reguladas por LexA em C.crescentus.

(Conclusão)

\begin{tabular}{lll}
\hline Gene & JAL (s) & Nome \\
\hline alkA & CC_2201 & 3-Metiladenina DNA glicosilase II \\
nei & Ausente & Endonuclease VIII \\
$x$ thA & CC_3706 & Exodeoxirribonuclease III \\
& CC_2011 & \\
\hline
\end{tabular}

Fonte: Martins-Pinheiro et al., 2007; Rocha et al., 2008.

Uma DNA glicosilase com importância significativa para este trabalho, e que, portanto será explorada agora em mais detalhes, é a endonuclease III. Ela é codificada pelo gene $n$th em $E$. coli e foi descrita inicialmente por sua capacidade de introduzir simples quebras em DNAs irradiados com altas doses de luz UV (Radman, 1976). Endonuclease III é específica para a remoção de resíduos de pirimidina oxidados, como timinas-glicol, uracilasglicol, 5,6-dihidrotiminas, 5-hidroxicitosinas e uréia (revisto por McCullough et al., 1999), que podem surgir após o tratamento com radiações ionizantes, baixos comprimentos de onda de luz UV ou peróxido de hidrogênio $\left(\mathrm{H}_{2} \mathrm{O}_{2}\right)$.

O mutante deste gene em $E$. coli foi descrito (Cunningham e Weiss, 1985), e ele não se mostrou mais sensível do que a cepa selvagem após a irradiação com raios gama ou tratamento com peróxido de hidrogênio $\left(\mathrm{H}_{2} \mathrm{O}_{2}\right)$. Sua freqüência de mutação espontânea, no entanto, era levemente aumentada. Este fenótipo aparentemente contraditório com a função da Endonuclease III foi explicado alguns anos depois, com a análise de mutantes para o gene nei e do duplo mutante para nth e nei (Saito et al., 1997). Existe sobreposição de funções entre $n t h$ e nei, sendo que o duplo mutante é extremamente sensível ao tratamento com $\mathrm{H}_{2} \mathrm{O}_{2}$, apesar de ter taxa de mutação espontânea semelhante ao mutante $n$ th.

Apesar de serem proteínas responsáveis pela remoção de lesões induzidas por $\mathrm{H}_{2} \mathrm{O}_{2}$, nth e nei não parecem ser induzidos após a administração deste e de outros agentes oxidantes, e nem são induzidos como partes dos regulons SOS ou OxyR (que responde a presença de $\mathrm{H}_{2} \mathrm{O}_{2}$ na célula) (Melamede et al., 1994). Na realidade, existem poucos dados na literatura a respeito da regulação de $n$th e nei. 
Como já foi mencionado, C. crescentus não possui ortólogos de nei; apesar disto, ela possui duas endonucleases III (CC_2272 e CC_3731). Curiosamente, CC_2272 demonstrou ser regulado por LexA, o que é um dado único no que se refere à regulação de genes de BER (Rocha et al., 2008). Para analisar mais profundamente o papel de cada um destes genes nas respostas de $C$. crescentus a agentes oxidativos, construímos neste trabalho mutantes para cada um deles individualmente e o mutante duplo.

\subsection{Síntese translesão: quando a lesão permanece}

Apesar do grande número de vias presentes nos procariontes para lidar com os danos na molécula de DNA, nem sempre é possível removê-los eficientemente. Nestes casos, a célula deve ter meios de tolerá-los e assim, conseqüentemente, sobreviver. Um mecanismo importante para a tolerância a lesões não reparadas é a síntese translesão, processo pelo qual uma polimerase específica insere nucleotídeos frente a lesões não reparadas, permitindo assim que a replicação do DNA prossiga.

As polimerases responsáveis pela síntese translesão pertencem tipicamente à família Y de DNA polimerases e diferem da polimerase replicativa da célula, que não é capaz de replicar frente à maioria das lesões, nos seguintes aspectos: elas não possuem a atividade editora 3'- 5' das polimerases replicativas, são bem distributivas na ausência de fatores de processividade (no caso, o 6-Clamp de E. coli) e replicam o DNA com fidelidade bem menor do que as polimerases de outras famílias (Friedberg et al., 2006). A taxa de incorporações erradas realizadas por estas polimerases pode ser entre $10^{-1}$ a $10^{-3}$ ( 1 base errada a cada 10 100 bases), uma taxa muito alta se comparada a das DNA polimerases replicativas, entre $10^{-6}$ e $10^{-8}$ ( 1 base errada a cada 1 milhão - 100 milhões de bases) (revisto por Kunkel, 2004).

E. coli possui duas polimerases da família $Y$ que são responsáveis pela síntese translesão, sendo aquela codificada pelo operon $u m u D C$ a mais importante para a replicação frente a lesões induzidas por luz UV. Os primeiros experimentos que estabeleceram os conceitos de reativação e mutagênese de Weigle demonstraram que a mutagênese após luz UV era dependente da resposta SOS (Defais et al., 1971). Logo foram identificados os genes 
responsáveis por este fenômeno em E. coli, umuC e umuD. UmuC é a polimerase da família $Y$, enquanto UmuD é um modulador de sua atividade. UmuD sofre clivagem in vivo em um mecanismo dependente de RecA e similar a clivagem de LexA; a forma clivada se associa então em dímeros e é capaz de ativar UmuC. A clivagem de UmuD também possui implicações interessantes para a regulação da mutagênese pós-UV: conforme os danos são reparados, RecA não mais estimula a clivagem de UmuD, e a forma não clivada não é capaz de modular positivamente a ação de UmuC (Battista et al., 1990). RecA exerce, portanto, uma regulação dupla sobre o operon $u m u D C$ : remove a inibição transcricional imposta por LexA e ativa UmuD, tornando o complexo competente para a síntese translesão.

C. crescentus não possui homólogos de umuDC em seu genoma. Neste organismo, uma segunda cópia da polimerase replicativa, dnaE2, presente em um operon com imuA e imuB, é responsável pela mutagênese pós-luz UV (Galhardo et al., 2005). Este operon, à semelhança de umuDC, também é regulado pela resposta SOS (Galhardo et al., 2005; Rocha et al., 2008). A caracterização dos mutantes para os genes deste operon (imuA e dnaE2) indica fenótipo semelhante ao observado para os mutantes em umuDC de E. coli (Kato, 1977; Steinborn, 1978; Bagg et al., 1961; Battista et al., 1990): sensibilidade muito moderada e ausência de mutagênese após a irradiação com UV.

\subsection{Resposta SOS: coordenando os esforços}

Muito foi falado nas seções anteriores sobre a resposta SOS. Uma vez que ela é um esforço amplo da célula bacteriana de lidar com diferentes tipos de danos e promover as respostas adequadas, iremos detalhá-la agora após a descrição das vias canônicas de reparo. Suas bases começaram a ser delineadas em 1953, com os experimentos de Jean Weigle (Weigle, 1953): a observação de que a irradiação com UV de E. coli antes da inoculação de fagos $\lambda$ também irradiados aumentava a sobrevivência dos fagos recebeu o nome de reativação Weigle. A fotorreativação de $E$. coli elimina este efeito, o que indica que danos ao DNA, como os CPDs, são necessários para que ocorra. Logo foram identificados genes que, 
quando mutados, eliminavam a reativação Weigle: recA (Brooks e Clark, 1967) e lexA (Defais et al., 1971), os reguladores do regulon SOS.

LexA é o repressor do sistema, se associando a seqüências conservadas nas regiões promotoras dos genes pertencentes ao regulon em condições não induzidas. Para que os genes deixem de ser reprimidos, é necessária a atuação de RecA. Basicamente, a criação de regiões de DNA simples fita por lesões que bloqueiam a DNA polimerase é o sinal indutor para a resposta SOS. RecA se associa a estas regiões e se ativa, sendo capaz de induzir uma função de autoprotease em LexA. LexA é então clivado entre a ligação Ala ${ }^{84}-\mathrm{Gly}^{85}$, o que retira a repressão dos genes do regulon (revisto por Crowley e Courcelle, 2002). Uma vez que os danos tenham sido reparados, o sinal indutor cessa e a repressão por LexA deve ser retomada (Figura 2).

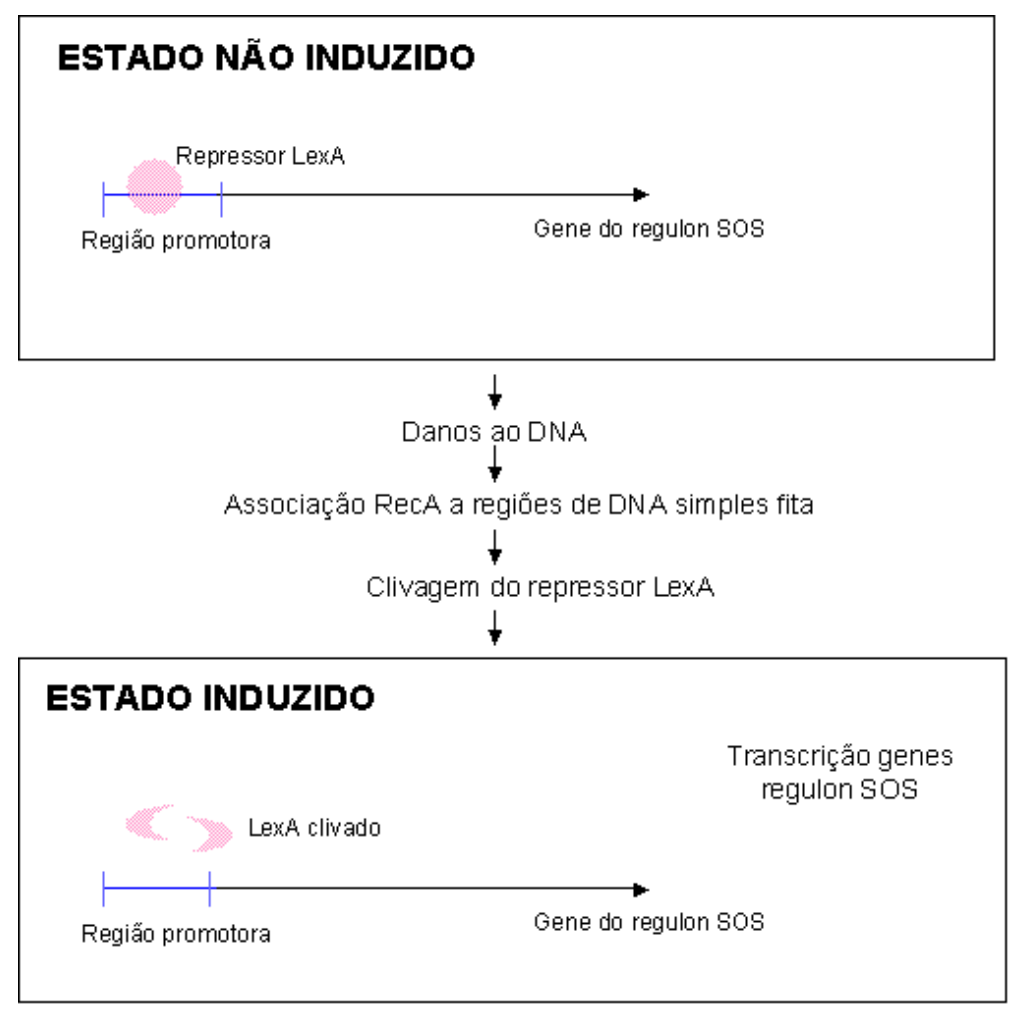

Figura 2 - Diagrama esquemático da ativação da resposta SOS. Em um estado não induzido, o regulador negativo LexA permanece associado à região promotora dos genes do regulon. Quando danos ocorrem e regiões de DNA simples fita surgem, RecA se associa a elas; sua forma ativada atua como co-protease na clivagem de LexA. Sem a repressão, os genes do regulon são então expressos Fonte: Modificada de Michel (2005). 
A proteína codificada por dinl, um gene regulado por LexA, é responsável por neutralizar o excesso de proteínas RecA, auxiliando a célula a retomar seu estado não induzido (Yasuda et al., 1998). Dinl é capaz se associar diretamente a RecA por mimetizar a estrutura do DNA simples fita (Voloshin et al., 2001).

RecA e LexA estão dentre os genes regulados por LexA, mas são expressos em níveis significativos mesmo em uma célula não induzida (existem, por exemplo, cerca de 7.200 moléculas de RecA por célula nesta situação em E. coli) (Sassanfar e Roberts, 1990). Isso é consistente com seu papel no início da resposta SOS, e no caso de RecA, com as outras funções que desempenha na célula (sendo a mais importante delas, possivelmente, a recombinação).

A resposta SOS é bem distribuída entre os procariontes, com poucas exceções descritas, como é o caso de Neisseria gonorrhoeae (Black et al., 1998). Duas características importantes desta resposta são, no entanto, muito variáveis: a seqüência reconhecida por LexA e o conjunto de genes sujeitos a regulação (Au et al., 2005; Cirz et al., 2007; Erill et al., 2003). Este regulon foi extensivamente estudado em E. coli; a identificação in silico de genes pertencentes ao regulon com base na identificação da seqüência operadora em suas regiões promotoras (Fernandez de Henestrosa et al., 2000; Lomba et al., 1997), bem como as análises de microarranjos de DNA comparando a expressão gênica em situações induzidas e não induzidas (irradiação por UV, tratamento com mitomicina C e cepas deficientes em lexA) (Courcelle et al., 2001; Khill e Camerini-Otero, 2002; Quillardet et al., 2003) levaram a identificação dos genes pertencentes ao regulon neste organismo. Uma lista com os mais importantes genes de E. coli se encontra abaixo (Tabela 3).

Tabela 3 - Genes pertencentes ao regulon SOS de $E$. coli e com função conhecida.

(Continua)

\begin{tabular}{ll}
\hline Gene (s) & Descrição / Função \\
\hline umuDC & DNA polimerase V - síntese translesão e mutagênese induzida por luz UV \\
$\operatorname{recA}$ & Recombinação e indução da resposta SOS \\
$\operatorname{sulA}$ & Inibição da divisão celular \\
$\operatorname{recN}$ & Reparo recombinacional de duplas quebras
\end{tabular}


Tabela 3 - Genes pertencentes ao regulon SOS de $E$. coli e com função conhecida.

(Conclusão)

\begin{tabular}{|c|c|}
\hline Gene (s) & Descrição / Função \\
\hline$u v r B$ & Reparo por excisão de nucleotídeos - reconhecimento da lesão \\
\hline lexA & Repressor do regulon SOS \\
\hline uvrA & Reparo por excisão de nucleotídeos - reconhecimento da lesão \\
\hline$s s b$ & Proteína que se liga a DNA fita simples \\
\hline$y / b G$ & Provável regulador transcricional com sítio de ligação a DNA \\
\hline ftsk & DNA translocase - segregação de cromossomos antes da divisão celular \\
\hline$u v r D$ & DNA helicase II - Reparo por excisão de nucleotídeos \\
\hline $\operatorname{ruv} A B$ & Helicase de Junções de Holliday, subunidades A e B \\
\hline polB & DNA polimerase II - síntese translesão \\
\hline $\operatorname{din} B$ & DNA polimerase IV - síntese translesão \\
\hline \multirow[t]{2}{*}{$y d j Q$} & Homólogo de UvrC, porção N-terminal - Reparo alternativo de excisão de \\
\hline & Nucleotídeos (Cho) \\
\hline dea & RNA helicase dependente de ATP \\
\hline $\operatorname{din} l$ & Inibidor da resposta SOS pelo impedimento da ativação de RecA \\
\hline pcrA & DNA helicase dependente de ATP \\
\hline
\end{tabular}

Fonte: Kenyon e Walker, 1980; Fernandez de Henestrosa et al., 2000; Quillardet et al., 2003; Courcelle et al., 2001.

A caracterização dos regulons SOS de outros organismos demonstrou que os genes identificados para $E$. coli não podem ser tomados como universais. O grupo de genes composto por lexA, recA, ssb, uvrA e ruvCAB foi considerado como sendo regulado por LexA em todas as proteobactérias (Erill et al., 2004). No entanto, na proteobactéria delta Bdellovibrio bacteriovorus, recA, uvrA, ruvCAB e ssb não são regulados por LexA (Campoy et al., 2005). Isso é mais uma demonstração de que devemos ter cautela na hora de extrapolar os dados de um organismo para outro. Neste trabalho descrevemos a caracterização do regulon SOS de $C$. crescentus através da construção de um mutante nulo para o repressor lexA. 


\subsection{Checkpoints em células procariontes: verdade ou mito?}

Checkpoint significa ponto de checagem. O conceito de checkpoint foi e ainda é extensivamente estudado em células eucariontes. A definição inicial nestas células postulava que os checkpoints eram mecanismos de controle que resultam em paradas específicas no ciclo celular em resposta a perturbações em um processo natural deste, como a replicação do cromossomo, a mitose ou a divisão celular (Hartwell e Weinert, 1989). Necessariamente, esta definição supõe que o controle seja externo ao processo em si (replicação, mitose ou divisão). A existência destes pontos de controle no ciclo celular bacteriano é motivo de discussão no meio científico há muitos anos.

Trabalhos iniciais neste campo indicaram que as células bacterianas poderiam possuir alguns mecanismos de checkpoint. Em um trabalho de Maaloe e Hanawalt (1961) foi descrito o bloqueio no início de novos ciclos de replicação do DNA em E. coli privada de aminoácidos. Em Helmstetter e Pierucci (1968) foi demonstrado que a divisão celular era inibida em células de $E$. coli irradiadas com luz UV, sendo que células em estágios avançados do ciclo celular eram capazes de se dividir, mas as demais não. Muitos pesquisadores não concordam com a categorização destes eventos como checkpoints reais, uma vez que não existe um mecanismo ativo de checagem externo ao sistema; o bloqueio do processo (no caso, replicação do DNA ou divisão celular) ocorre por controles internos, que tentam garantir que um processo anterior termine para que o processo seguinte possa começar (Cooper, 2006).

Ainda assim, é bem aceito que o bloqueio da divisão celular mediado pela resposta SOS seja um exemplo de checkpoint bacteriano (Autret et al., 1997). Este fenômeno é mediado em E. coli por SulA, um membro do regulon de LexA. Quando ocorre a indução da resposta, a transcrição de sulA é altamente induzida, podendo atingir até dez vezes após 5 minutos da irradiação com $25 \mathrm{~J} / \mathrm{m}^{2}$ de UV (Courcelle et al., 2001). SulA então interage diretamente com FtsZ inibindo a polimerização de seu anel no septo divisional (Mukherjee et al., 1998). A montagem do anel $Z$ é um dos primeiros passos do estabelecimento do divisossomo, sendo responsável por recrutar as demais proteínas de divisão para o septo. A inibição por SulA gera crescimento celular sem que ocorra a divisão, resultando em células 
com aspecto filamentoso (Huisman et al., 1984). E é por esse mesmo motivo que o estabelecimento de mutantes nulos para o gene lexA em $E$. coli não é possível: na ausência de regulação, a filamentação mediada por sulA é letal. Para que a célula seja viável é necessário, portanto, conjugar mutações em lexA e sulA (Mount, 1977).

A filamentação mediada pela resposta SOS é um fenômeno bem difundido entre as bactérias. A maioria destas não possui em seus genomas homólogos de sulA; demonstrouse, na verdade, que este gene está restrito a organismos filogeneticamente próximos a $E$. coli (Erill et al., 2003). Em Bacillus subtilis, a filamentação do mutante dinR (homólogo de lexA) é mediada pelo produto do gene yneA, o primeiro gene de um operon pertencente ao regulon SOS e transcrito divergentemente em relação à lexA. O mecanismo sugerido é de que YneA atue também bloqueando a formação do anel de $Z$ (Kawai et al., 2003). Já o inibidor de divisão celular identificado em outra bactéria Gram positiva, Corynebacterium glutamicum (Ogino et al., 2007), aparentemente bloqueia a divisão celular sem interagir diretamente com FtsZ. Neste organismo, o gene responsável pela filamentação após a ativação da resposta SOS é divS, que não é homólogo a sulA ou yneA. Em Mycobacterium tuberculosis é a JAL rv2719c que codifica o inibidor da divisão celular, e este não é homólogo a nenhum dos genes descritos acima (Chauhan et al., 2006). As estruturas preditas destas proteínas também não revelam quaisquer semelhanças entre elas.

Neste trabalho demonstramos a construção de um mutante nulo para o gene lexA de C. crescentus (Rocha et al., 2008). A cepa em questão é viável, mas apresenta fenótipo filamentoso. $C$. crescentus também não possui homólogos a sulA ou a qualquer dos outros genes mencionados acima, e por isso, parte deste trabalho foi dedicada a investigar qual seria o gene responsável pelo fenótipo observado.

Nossa busca por checkpoints bacterianos não se resumiu, no entanto, a análise da filamentação mediada por LexA. Conforme descrito anteriormente, $C$. crescentus possui um ciclo celular complexo e sujeito a vários níveis de controle. Por esse motivo, a especulação de que esta bactéria possa ter mecanismos adicionais que acoplem a integridade do material genético à progressão do ciclo celular é tentadora. Neste caso, buscamos checkpoints mais próximos àqueles observados em células eucariontes. Já foi descrita a existência em $C$. crescentus de um checkpoint que impede a divisão celular na ocorrência de bloqueios na replicação do DNA por hidroxiuréia (Wortinger et al., 2000). Nas células pré-divisionais 
bloqueadas para a replicação do DNA, CtrA não é acumulado e nem sintetizado, o que acaba por não ativar a síntese dos genes fts $Q$ e $f t s A$, que em condições normais são recrutados por FtsZ para o divisossomo. Este efeito não possui qualquer relação com a resposta SOS, pois ele continua ocorrendo em uma célula $r e c A^{-}$.

Neste sentindo e com o auxílio dos mutantes deficientes no reparo por excisão de nucleotídeos e em síntese translesão, além da utilização da técnica de citometria de fluxo, analisamos as respostas relacionadas à progressão do ciclo celular em $C$. crescentus frente a danos induzidos no DNA pela luz UVC, que são principalmente os dímeros de pirimidina ciclobutanos (CPDs). Desta forma, buscamos expandir o conhecimento atual sobre a existência ou não de mecanismos de checkpoints em células procariontes. 


\section{OBJETIVOS}

Os objetivos deste trabalho podem ser divididos em duas partes. Na primeira delas, buscamos expandir os conhecimentos a cerca dos mecanismos de reparo em $C$. crescentus, a fim de melhor entender como este organismo lida com o ambiente a seu redor e as agressões que sofre a todo o momento.

Os objetivos específicos desta seção são:

- Caracterizar a resposta SOS de C. crescentus através da construção de uma cepa deficiente para o gene lexA, repressor do sistema em questão, e comparação da expressão de genes preditos em uma análise in silico nesta cepa e na selvagem NA1000

- Validação in vivo da sequencia do operador SOS encontrada como parte da análise in silico

- Analisar o fenótipo de cepas deficientes no gene CC_2272, uma endonuclease III regulada por LexA, e em CC_3731, uma endonuclease III não regulada por LexA

- Analisar o perfil de expressão de CC_2433 e dnaB, que parecem ser regulados positivamente por LexA, em cepas deficientes em CC_3225 (histidina quinase híbrida) e RM20 (deficiente nos genes CC_3036-CC-3037-CC3038)

- Construir uma cepa mutante para CC_2433 e analisar seu papel na resposta SOS

Em uma segunda parte, buscamos desvendar os mecanismos pelos quais $C$. crescentus acopla a progressão de seu ciclo celular a danos sofrido na molécula de DNA.

Aqui, os objetivos específicos são:

- Buscar o gene responsável pelo bloqueio da divisão celular e conseqüente fenótipo filamentoso de cepa lexA

- Analisar as relações entre danos ao DNA mediados por luz UV e o seu reparo com a progressão do ciclo celular em cepas deficientes em reparo por excisão de nucleotídeos e síntese translesão, bem como na cepa selvagem 


\section{MATERIAIS E MÉTODOS}

\subsection{Manutenção e Cultivo de cepas de $C$. crescentus}

As cepas de $C$. crescentus foram cultivadas em meio PYE (Ely, 1991) (2 g/L peptona, 1 $\mathrm{g} / \mathrm{L}$ extrato de levedura, 0,2 $\mathrm{g} / \mathrm{L} \mathrm{MgSO}_{4}, 0,5 \mathrm{mM} \mathrm{CaCl} 2$ acrescido de 7,5 g/L de agar para a confecção de meio PYE sólido), sempre a $30{ }^{\circ} \mathrm{C}$. Quando necessário, os antibióticos a seguir foram utilizados nas seguintes concentrações: $20 \mu \mathrm{g} / \mathrm{ml}$ ampicilina, $20 \mu \mathrm{g} / \mathrm{ml}$ ácido nalidíxico, $5 \mu \mathrm{g} / \mathrm{ml}$ canamicina, $2 \mu \mathrm{g} / \mathrm{ml}$ tetraciclina e $50 \mu \mathrm{g} / \mathrm{ml}$ espectinomicina. Os estoques destas cepas foram mantidos com DMSO $10 \%$ a $-80{ }^{\circ} \mathrm{C}$. A cepa NA1000 foi utilizada com parental para as disrupções gênicas e demais experimentos, exceto quando indicado.

\subsection{Manutenção e Cultivo de cepas de $E$. coli}

As cepas de E. coli DH10B (F- mcrA $\Delta$ (mrr-hsdRMS-mcrBC) $\varphi 80$ lacZDM15 $\Delta$ lacX74 recA1 endA1 araD139 $\Delta$ (ara, leu) 7697 galU galK $\lambda$-rpsL nupG /pMON14272 / pMON7124) (Invitrogen, EUA) e S17-1 (recA pro hsdR RP4-2-Tc::Mu-Km::Tn7) (Simon et al., 1983) foram cultivadas em meio LB (10 g/L peptona, $5 \mathrm{~g} / \mathrm{L}$ extrato de levedura, $10 \mathrm{~g} / \mathrm{L} \mathrm{NaCl}$, acrescido de 7,5 g/L de agar para a confecção de meio LB sólido), sempre a $37^{\circ} \mathrm{C}$. Quando necessário, os antibióticos a seguir foram utilizados nas seguintes concentrações: $100 \mu \mathrm{g} / \mathrm{ml}$ ampicilina, 50 $\mu \mathrm{g} / \mathrm{ml}$ canamicina, $15 \mu \mathrm{g} / \mathrm{ml}$ tetraciclina e $50 \mu \mathrm{g} / \mathrm{ml}$ espectinomicina. Os estoques destas cepas foram mantidos com glicerol $20 \%$ a $-80{ }^{\circ} \mathrm{C}$. 


\subsection{Obtenção de bactérias competentes}

Para a obtenção de bactérias quimiocompetentes foram utilizadas as cepas $\mathrm{DH} 10 \mathrm{~B}$ e S17-1 e a técnica descrita por Hanahan (1983). Uma colônia de uma placa recente de LB agar era inoculada em $2 \mathrm{ml}$ de meio SOB (20 g/L peptona, $5 \mathrm{~g} / \mathrm{L}$ extrato de levedura, 0,5 g/L NaCl, 2,5 $\mathrm{mM} \mathrm{KCl}, 10 \mathrm{mM} \mathrm{MgCl}$, com pH final de 7,0; o $\mathrm{MgCl}_{2}$ deve ser acrescentado apenas após a autoclavagem) e mantida sob agitação constante a $37{ }^{\circ} \mathrm{C}$ por aproximadamente 16 horas. Este pré-inóculo era então transferido para $50 \mathrm{ml}$ de meio SOB e mantido sob agitação a 37 ${ }^{\circ} \mathrm{C}$ por mais 2 - 3 horas para que atingisse D.0.540nm entre 0,5 e 0,6. O frasco de cultivo era então transferido para um recipiente com gelo e era adicionado 0,5 $\mathrm{ml}$ de $\mathrm{MgCl}_{2} 1 \mathrm{M}$. A cultura era transferida para tubos de polipropileno de $50 \mathrm{ml}$ previamente imersos em gelo e deixada em repouso por 15 minutos. As células eram precipitadas a $3.000 \mathrm{rpm}$ por 12 minutos a $4{ }^{\circ} \mathrm{C}$, e seu sobrenadante era descartado a seguir. As bactérias eram ressuspendidas gentilmente em $10 \mathrm{ml}$ da solução $\mathrm{RF}$ I $\left(100 \mathrm{mM} \mathrm{KCl}, 50 \mathrm{mM} \mathrm{MnCl}\right.$. $4 \mathrm{H}_{2} \mathrm{O}, 30$ $\mathrm{mM}$ de acetato de potássio, $10 \mathrm{mM} \mathrm{CaCl} 2.2 \mathrm{H}_{2} \mathrm{O}, 15 \%$ glicerol; o $\mathrm{pH}$ final deve estar acima de 5,8 ) e deixadas em repouso em gelo por 15 minutos. A seguir, eram centrifugados a 3.000 rpm por 12 minutos a $4{ }^{\circ} \mathrm{C}$, descartado o sobrenadante e ressuspendidas as bactérias em 2 ml de solução RF II (10 mM Na-MOPS, $10 \mathrm{mM} \mathrm{KCl,} 75$ mM CaCl $2.2 \mathrm{H}_{2} \mathrm{O}, 15 \%$ glicerol; o pH final deve ser de 6,8). A suspensão bacteriana era então dividida em alíquotas (cerca de 200 $\mu$ l por alíquota) e estocada a $-80^{\circ} \mathrm{C}$ até o momento do uso.

\subsection{Transformação bacteriana}

As alíquotas de $E$. coli competentes mantidas a $-80^{\circ} \mathrm{C}$ eram descongeladas em gelo e utilizados $50 \mu \mathrm{l}$ destas por ligação / plasmídeo. O DNA de interesse era transferido para um tubo mantido no gelo, respeitando o volume máximo de $5 \mu$ l por reação, sendo a suspensão bacteriana adicionada sobre este e então ambos gentilmente homogeneizados. Esta mistura era mantida por 30 minutos no gelo, e então submetida a choque térmico por 90 segundos a 
$42{ }^{\circ} \mathrm{C}$ e devolvida para o gelo por mais 10 minutos. Transcorrido este tempo, eram adicionados $500 \mu \mathrm{l}$ de meio SOC (meio SOB acrescido de $20 \mathrm{mM}$ de glicose na hora do uso) e transferidos os tubos para $37^{\circ} \mathrm{C}$ por 1 hora. Após o tempo de recuperação, $100 \mu \mathrm{l}$ das bactérias eram plaqueados em placas de LB agar acrescidas do antibiótico de interesse e incubadas por 16 horas a $37^{\circ} \mathrm{C}$.

\subsection{Preparação de DNA plasmidial}

A extração de plasmídeos de interesse em pequena escala foi realizada a partir do método de lise alcalina, adaptado do protocolo original de Birnboim e Doly (1979). Colônias bacterianas portando o plasmídeo de interesse eram inoculadas em $2 \mathrm{ml}$ de meio LB acrescido do antibiótico necessário e mantidas sob agitação constante a $37^{\circ} \mathrm{C}$ por 16 horas. Esta cultura era centrifugada a $12.000 \mathrm{~g}$ por 30 segundos a $4{ }^{\circ} \mathrm{C}$, o sobrenadante descartado e o precipitado ressuspendido em $100 \mu$ de solução 1 (50 mM glicose, 25 mM Tris.Cl pH 8, $10 \mathrm{mM}$ EDTA pH 8). Eram adicionados $200 \mu \mathrm{l}$ de solução 2 feita no momento do uso $(0,2 \mathrm{~N}$ de $\mathrm{NaOH}, 1 \%$ SDS) para a lise celular, invertidos os tubos aproximadamente 5 vezes e incubados em gelo por 5 minutos. Adicionamos $150 \mu \mathrm{l}$ da solução 3 (5 M acetato de potássio, $115 \mathrm{ml} / \mathrm{L}$ de ácido acético glacial), os tubos eram invertidos novamente e mantidos no gelo por 5 minutos. Este material foi então centrifugado a 12.000 g por 5 minutos a $4{ }^{\circ} \mathrm{C}$. O sobrenadante foi transferido para outro tubo e a este foram adicionados 2 volumes de etanol 100\%; centrifugamos novamente a $12.000 \mathrm{~g}$ por 5 minutos a $4{ }^{\circ} \mathrm{C}$ e removemos o sobrenadante, deixando o interior do tubo seco. O precipitado inicial de DNA era então lavado com $1 \mathrm{ml}$ de etanol 70\% gelado e centrifugado mais uma vez a $12.000 \mathrm{~g}$ por 5 minutos a $4{ }^{\circ} \mathrm{C}$. O sobrenadante era retirado, e o DNA precipitado foi seco a temperatura ambiente e então ressuspendido em $50 \mu \mathrm{l}$ de TE (10 mM Tris.Cl, 1 mM EDTA pH 8) contendo $20 \mu \mathrm{g} / \mathrm{ml}$ de RNase A (Invitrogen, EUA). Esta solução era então mantida a $65{ }^{\circ} \mathrm{C}$ por 15 minutos e estocada a $-20^{\circ} \mathrm{C}$ até o momento do uso.

Quando DNAs plasmidiais de maior grau de pureza eram necessários, as preparações plasmidiais em pequena escala eram realizadas com os kits S.N.A.P. ${ }^{\text {'M }}$ Mini Prep Purification 
Kit (Invitrogen, EUA) ou Illustra Plasmid Prep Mini Spin Kit (GE Healthcare, EUA), seguindo os protocolos indicados pelos fabricantes. Na eventual necessidade de maiores concentrações de DNA, utilizávamos o kit para preparações em média escala QIAGEN Plasmid Midi Kit (Qiagen, EUA).

Os DNAs obtidos neste protocolo e em outros descritos a seguir eram verificados através de géis de agarose 0,8\% em tampão TBE 0,5 X (53 g/L Tris base, 27,5 g/L ácido bórico, $10 \mathrm{mM}$ EDTA pH 8 para solução estoque $5 \mathrm{X}$ ) contendo brometo de etídeo com o auxílio do Image Quant 300 (GE Healthcare, EUA). A quantificação dos DNAs foi realizada através do espectrofotômetro NanoDrop 1000 (Thermo Scientific, EUA).

\subsection{Seqüenciamento de DNA}

As reações de seqüenciamento foram realizadas utilizando protocolo estabelecido em nosso laboratório. Cerca de 100 a 200 ng de DNAs de alta qualidade (extraídos com auxílio dos kits acima descritos) eram utilizados para cada reação. Para uma reação final de $20 \mu \mathrm{l}$ acrescentávamos ao DNA $6 \mu \mathrm{l}$ do tampão Save Money $(200 \mathrm{mM}$ de Tris- $\mathrm{HCl}, 5$ mM de $\mathrm{MgCl}_{2}$, com $\mathrm{pH}$ 9,0), 3,2 pmoles dos oligonucleotídeos necessários, $2 \mu$ do BigDye Terminator Cycle Sequencing Ready Reaction - versão 3.1 (Applied Biosystems, EUA) e água MilliQ até atingir o volume total. As reações eram submetidas a 40 ciclos compostos dos seguintes passos: $96{ }^{\circ} \mathrm{C}$ por 10 segundos, $52{ }^{\circ} \mathrm{C}$ por 20 segundos, $60{ }^{\circ} \mathrm{C}$ por 4 minutos. Os termocicladores utilizados nestes experimentos e nos demais aonde se fizeram necessários foram PTC-100 (MJ Research Inc., EUA) ou Master Cycler Gradient (Eppendorf, Alemanha).

Os produtos das reações de seqüenciamento foram então precipitados através da adição de $100 \mu \mathrm{l}$ de isopropanol 70\% e incubados por 10 minutos a temperatura ambiente. As reações foram centrifugadas a $4.000 \mathrm{rpm}$ por 50 minutos a $20^{\circ} \mathrm{C}$, o isopropanol descartado e elas foram lavadas com $150 \mu \mathrm{l}$ de etanol 70\%. Centrifugamos novamente a $4.000 \mathrm{rpm}$ por 10 minutos a $20^{\circ} \mathrm{C}$ e descartamos o etanol. As amostras foram mantidas a 37 ${ }^{\circ} \mathrm{C}$ por 30 minutos para a completa evaporação do etanol e guardadas então a $-20{ }^{\circ} \mathrm{C}$ até o momento do seqüenciamento. 
Para o seqüenciamento propriamente dito, foram adicionados $20 \mu \mathrm{l}$ de formamida $\mathrm{Hi}$ Di às amostras; estas foram então desnaturadas por 4 minutos a $96{ }^{\circ} \mathrm{C}$, colocadas no gelo por 1 minuto e então submetidas ao seqüenciamento em um seqüenciador capilar ABI-Prism 3100 (Applied Biosystems, EUA).

Com os dados do seqüenciamento, prosseguimos para a análise in silico, com o auxílio do programa Consed Phred Phrap (Linux), onde foram gerados os contigs e a qualidade da seqüência foi checada, e do site do National Center for Biotechnology Information (NCBI), onde, através do recurso Blast 2 sequences, a seqüência gerada foi comparada com uma seqüência do DNA genômico de $C$. crescentus CB15 correspondente ao gene de interesse depositada no banco de dados. Adicionalmente, os cromatogramas também foram analisados com o auxílio do software Bio Edit.

\subsection{Irradiações com luz UVC}

As irradiações descritas neste trabalho foram realizadas em condições controladas no laboratório pelo uso da lâmpada de UVC Phillips UVC lamp TUV 15 W/G15 T8. As taxas de dose dessa e de outras lâmpadas que emitem no comprimento de onda correspondente a UV foram medidas pelo Radiômetro de UV VLX 3W (Vilber Lourmat, França) e correspondem a $3,26 \mathrm{~J} / \mathrm{m}^{2} / \mathrm{s}$ para a lâmpada de UVC e $87 \mathrm{~J} / \mathrm{m}^{2} / \mathrm{s}$ para a lâmpada de UVA.

\subsection{Microscopia}

Uma alíquota de aproximadamente $10 \mu \mathrm{l}$ de uma cultura das cepas de $C$. crescentus crescidas por aproximadamente 16 horas era colocada em uma lâmina de vidro e coberta a seguir com uma lamínula. As observações microscópicas foram realizadas em um aparelho Axiovert 200 (Zeiss, Alemanha), utilizando contraste de fase. 


\subsection{Oligonucleotídeos}

Todos os oligonucleotídeos utilizados neste trabalho foram desenhados com o auxílio do software Primer Express (Applied Biosystems, EUA) e sintetizados pela Invitrogen, Prodimol ou Sigma. Eles se encontram listados em tabela anexa no final desta tese.

\subsection{Obtenção de cepas mutantes}

\subsubsection{Obtenção de cepas mutantes pelo método de deleção em fase}

A construção das cepas mutante de C. crescentus para os genes lexA (CC_1902), CC_2272, CC_2433 e CC_0627 foi realizada através de deleção em fase das JALs em questão por dois eventos subseqüentes de recombinação homóloga. A construção foi desenhada para que a deleção resultante mantivesse a fase de leitura dos genes, e assim não comprometesse a estabilidade dos transcritos e conseqüentemente a expressão de genes a $3^{\prime}$ a partir dos mesmos.

Para a deleção em fase, dois fragmentos foram amplificados a partir do DNA genômico da cepa parental NA1000 por PCR. O primeiro fragmento contém o início da JAL de interesse somado a algumas centenas de bases a 5' desta; o segundo fragmento, contém a porção final da JAL, somado a algumas bases a 3' desta. Todos os fragmentos obtidos por PCR foram primeiramente clonados no vetor pGEM-T easy (Promega) e seqüenciados para garantir que mutações adicionais não tivessem sido inseridas (Figura 3). 


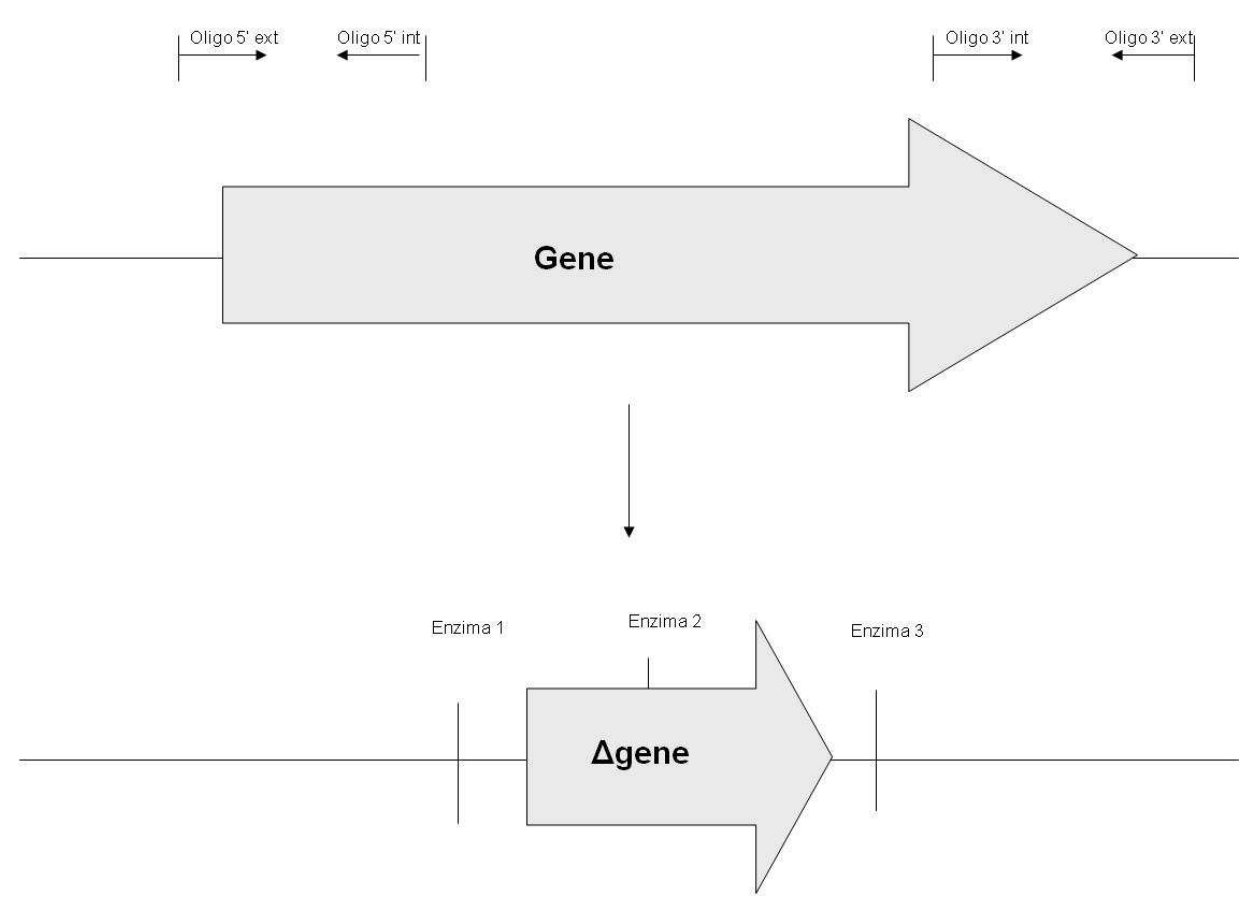

Figura 3 - Esquema representativo da construção de mutantes pelo método de deleção em fase. Os iniciadores e sítios de restrição utilizados se encontram indicados na figura.

A construção era subclonada no vetor suicida pNPTS138 (Tsai et al., 2000) e passada para as cepas de $C$. crescentus através de conjugação com a cepa S17-1 de $E$. coli. Este vetor possui o gene $n p t l$, que confere resistência a canamicina e o gene $s a c B$, que confere sensibilidade a sacarose por transformá-la em um metabólito tóxico. Os conjugantes iniciais de $C$. crescentus foram selecionados pela resistência a canamicina para determinar quais deles haviam recebido o plasmídeo; adicionamos também ácido nalidíxico, que impede o crescimento de $E$. coli, mas não interfere no crescimento de $C$. crescentus. A perda do plasmídeo após o segundo evento de recombinação era selecionada em meio PYE contendo $3 \%$ de sacarose (Figura 4). Os clones recombinantes candidatos a possuírem as disrupções gênicas desejadas eram confirmados por PCR diagnóstico. 


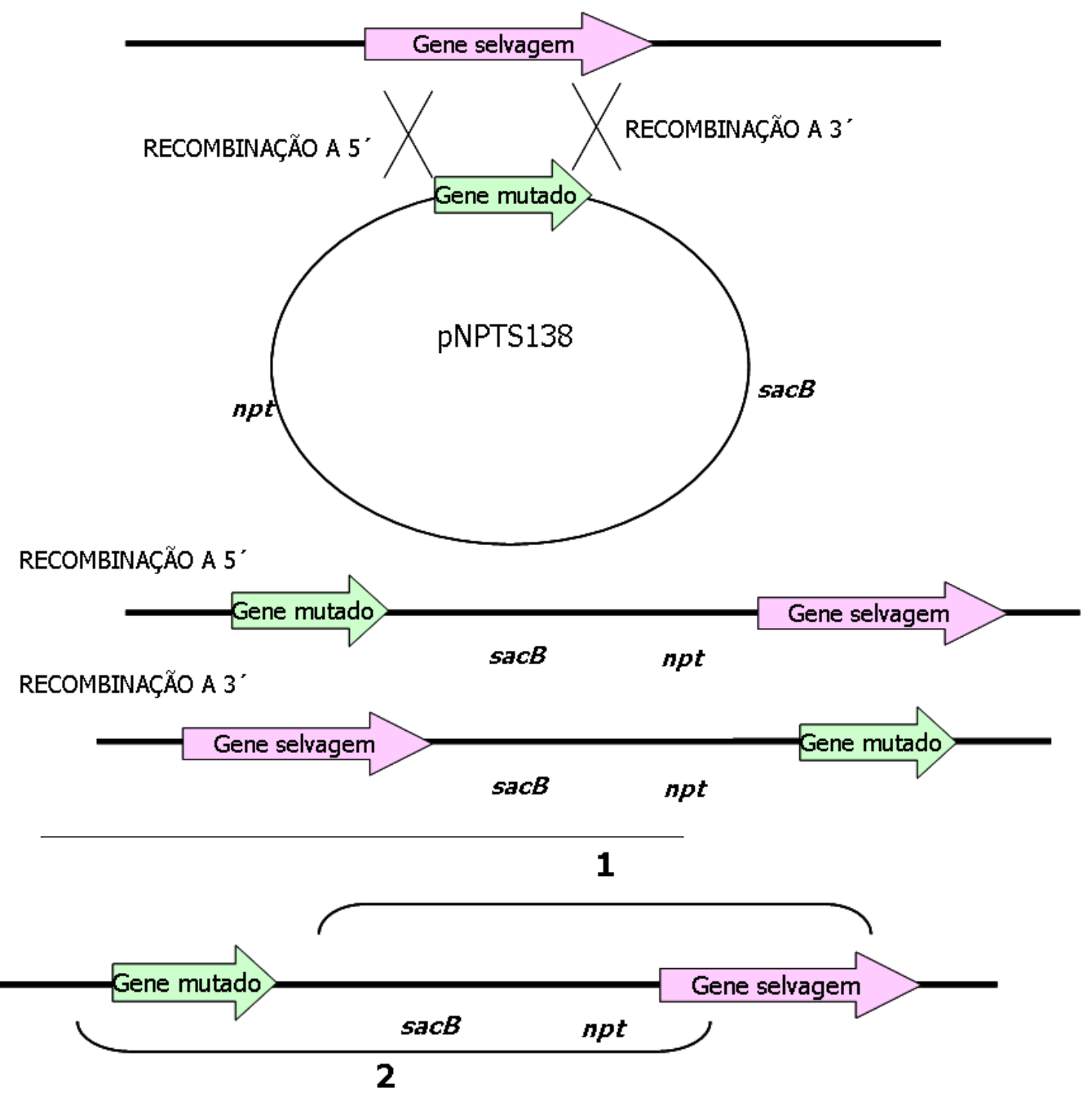

1
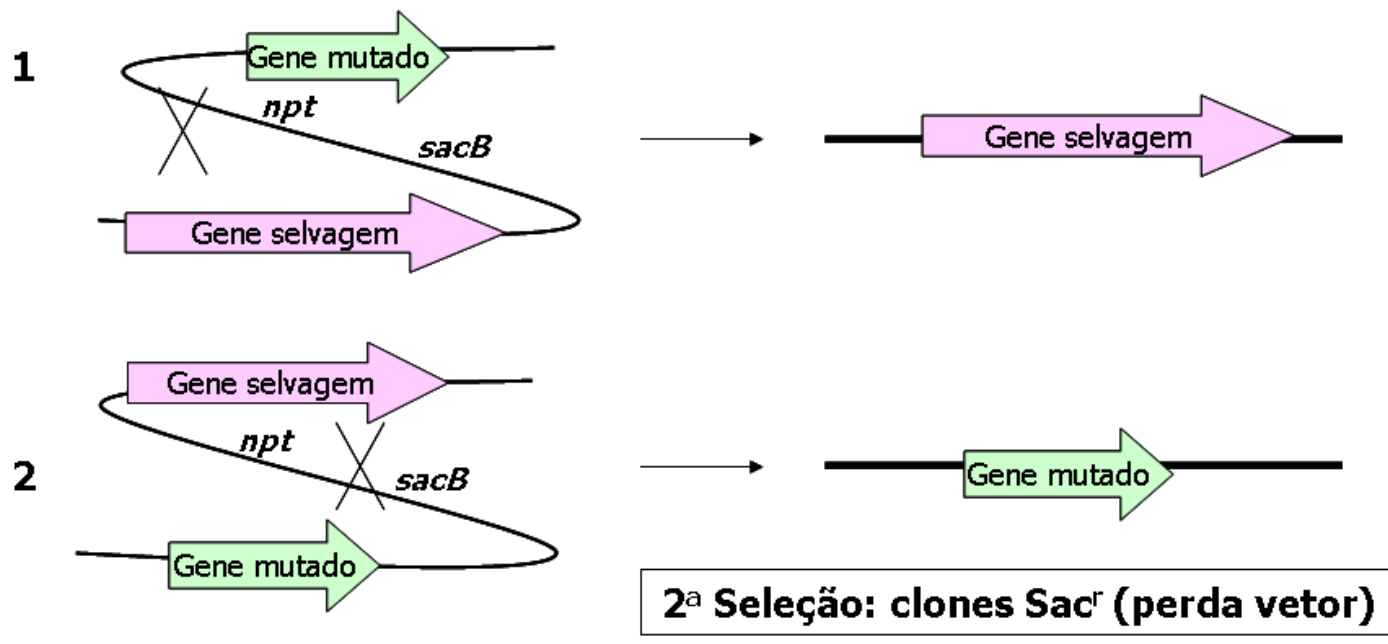

Confirmação: clones Can ${ }^{\mathrm{s}}$

Figura 4 - Esquema representativo das etapas de recombinação e seleção dos mutantes construídos com a utilização do vetor pNPTS138. 


\subsubsection{Obtenção de cepas mutantes pelo método de deleção em fase e inserção de cassete de resistência a espectinomicina}

A construção da cepa mutante de C. crescentus para o possível operon CC_3038CC_3037-CC_3036 foi realizada através de deleção em fase das JALs e subseqüente adição de um cassete de resistência à espectinomicina.

Para a deleção em fase, dois fragmentos foram amplificados a partir do DNA genômico da cepa parental NA1000 por PCR. O primeiro fragmento, obtido a partir dos iniciadores 3038delext e 3038delint, contém uma região de 455 pb a 5' do início da JAL CC_3038 e 88 bases da região codificante; o segundo fragmento, obtido a partir dos iniciadores 3036delint e 3036delext, contém as 27 últimas bases da JAL CC_3036, mais 627 bases a $3^{\prime}$ desta. Todos os fragmentos obtidos por PCR foram primeiramente clonados no vetor pGEM-T easy e seqüenciados para garantir que mutações adicionais não tivessem sido inseridas. Os fragmentos 1 e 2 foram então ligados com auxílio da enzima T4-ligase (Promega, EUA) e clonados no vetor pNPTS138.

Obtivemos o cassete de resistência a espectinomicina a partir do vetor pHP45 $\Omega$ (Prentki e Krisch, 1984) e o inserimos no interior da cópia deletada do possível operon a partir do sítio de restrição da enzima Smal criado em seu interior após a reação de ligação (Figura 5). 

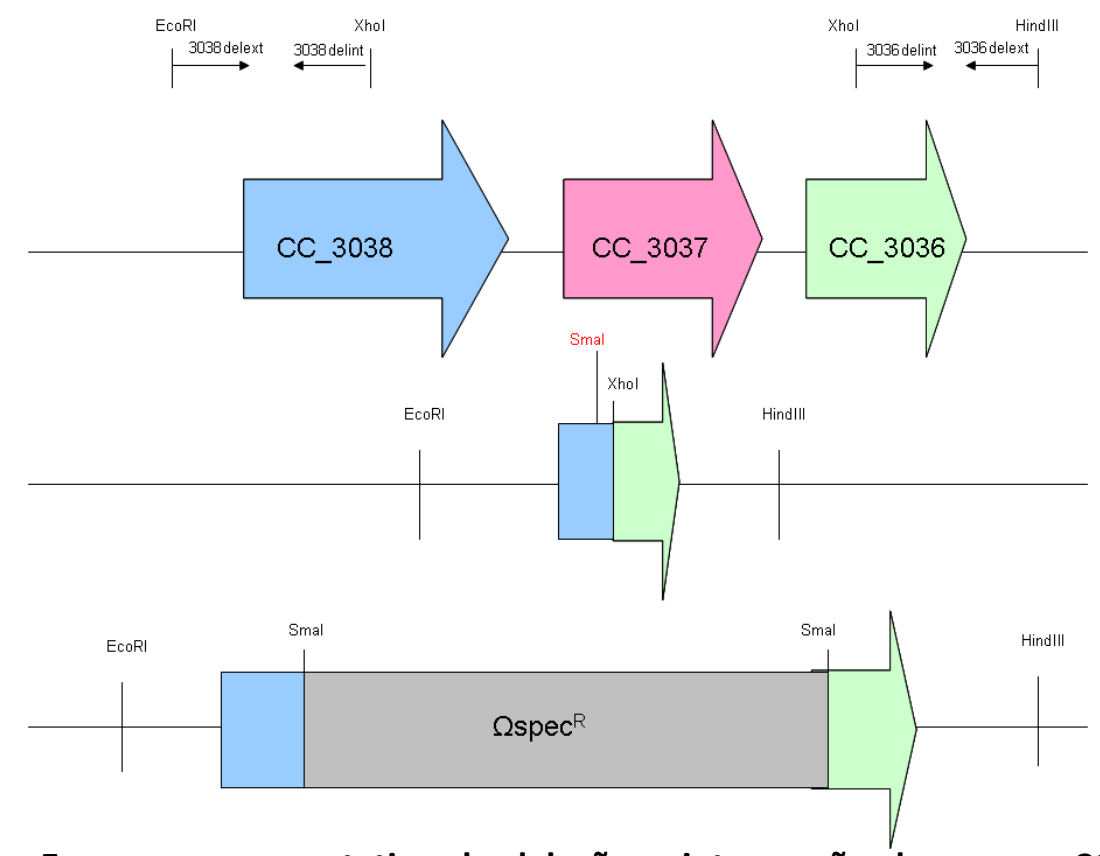

Figura 5 - Esquema representativo da deleção e interrupção do operon CC_3038-CC_3037CC_3036 pelo cassete de resistência a espectinomicina. Os iniciadores e sítios de restrição utilizados se encontram indicados na figura.

Esta nova construção foi então utilizada para transformar a cepa S17-1 de E. coli, e então transferida para $C$. crescentus através de conjugação. As seleções dos conjugantes foram realizadas conforme descrito no item 3.10.1 (com a adição também de espectinomicina, a marca de resistência encontrada no cassete), bem como sua confirmação.

\subsubsection{Obtenção de cepas mutantes pela interrupção da região codificante pelo cassete de} resistência a espectinomicina

A construção da cepa mutante de $C$. crescentus para o gene CC_3731 foi realizada através da inserção de um cassete de resistência à espectinomicina no interior da região codificante, resultando provavelmente em uma proteína truncada e não funcional.

A cópia selvagem do gene CC_3731 mais regiões flanqueadoras (381 pb a 5' e 180 pb a 3') foi amplificada a partir do DNA genômico da cepa parental NA1000 por PCR como 
auxílio dos iniciadores 3731fow e 3731rev. O fragmento obtido possuía 1.287 pb e foi primeiramente clonado no vetor pGEM-T easy e seqüenciado. Este plasmídeo foi então digerido com a enzima EcoRV, cujo sítio estava presente no interior do gene, para a posterior inserção do cassete de resistência a espectinomicina obtido a partir do vetor pHP45 $\Omega$ (Figura $6)$.
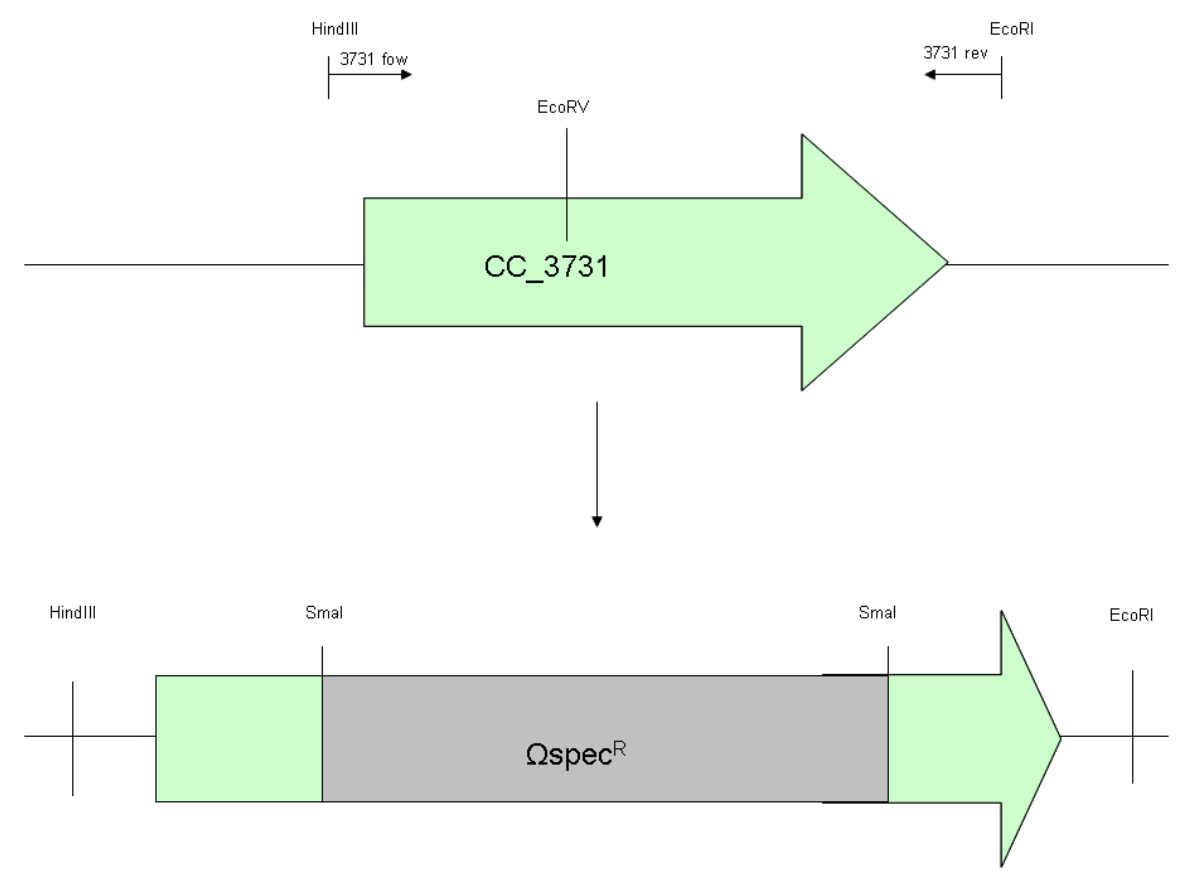

Figura 6 - Esquema representativo da interrupção do gene CC_3731 pelo cassete de resistência a espectinomicina. Os iniciadores e sítios de restrição utilizados se encontram indicados na figura.

Esta nova construção foi subclonada no vetor pNPTS138 (Tsai et al., 2000), transferida para a cepa S17-1 de E. coli por transformação, e então transferida para $C$. crescentus através de conjugação. As seleções dos conjugantes foram realizadas conforme descrito no item 3.10.1 (com a adição também de espectinomicina, a marca de resistência encontrada no cassete), bem como sua confirmação. 


\subsection{Complementação do mutante lexA}

Uma cópia selvagem do gene lexA foi amplificada a partir dos oligonucleotídeos lexA5ext2 e lexAre. O fragmento resultante, que tinha $1.481 \mathrm{pb}$ (incluindo o gene lexA mais 597 pb a 5' do início de transcrição e 146 pb após o término), foi clonado inicialmente no vetor pGEM-T Easy e seqüenciado para a verificação de sua integridade. O fragmento foi então digerido com auxílios da enzima cujo sítio estava contido nos iniciadores (EcoRI), subclonado no vetor de baixo número de cópias pMR20 (Roberts et al., 1996) e utilizado para transformar a cepa S17-1 de E. coli. A transferência para $C$. crescentus foi feita através de conjugação. A seleção foi realizada pela marca de resistência do plasmídeo (tetraciclina) e por ácido nalidíxico.

\subsection{Ensaios de crescimento}

Culturas das cepas de $C$. crescentus crescidas por aproximadamente 16 horas a $30{ }^{\circ} \mathrm{C}$ a partir de uma única colônia eram diluídas para D.O.600nm 0,1 em meio PYE e mantidas sob constante agitação a mesma temperatura. A cada intervalo de tempo (1 hora e 30 minutos), duas alíquotas desta cultura eram retiradas; a primeira era utilizada para a aferição da densidade ótica e a segunda era diluída seriadamente e plaqueada em meio PYE para a aferição das unidades formadora de colônia. As placas eram mantidas por 2 dias a $30{ }^{\circ} \mathrm{C}$, e então o número de colônias era contado.

\subsection{Extração de DNA genômico de $C$. crescentus}

Culturas de $C$. crescentus crescidas a partir uma colônia por aproximadamente 16 horas a 30 ${ }^{\circ} \mathrm{C}$ eram precipitadas a $12.000 \mathrm{rpm}$ por 5 minutos. É importante ressaltar que em extrações 
de DNA genômico as pontas das ponteiras utilizadas são sempre cortadas a fim de minimizar a introdução de quebras mecânicas no DNA. O sobrenadante era descartado, o precipitado bacteriano ressuspendido em $200 \mu \mathrm{l}$ de solução de lise $(40 \mathrm{mM}$ Tris acetato pH 7,8, $20 \mathrm{mM}$ acetato de sódio, $1 \mathrm{mM}$ EDTA, 1\% SDS) e então eram adicionados $66 \mu \mathrm{l}$ de $\mathrm{NaCl} 5 \mathrm{M}$. A mistura era centrifugada a $14.000 \mathrm{rpm}$ por 15 minutos e o sobrenadante recuperado em outro tubo. A este era acrescentado igual volume de clorofórmio, e o tubo era invertido gentilmente até a mistura ficasse translúcida. Centrifugamos a $12.000 \mathrm{rpm}$ por 3 minutos e recuperamos o sobrenadante em um tubo mantido em gelo; eram adicionados 2 volumes de etanol $100 \%$ gelado para iniciar a precipitação do DNA. Centrifugamos novamente a 12.000 rpm por 10 minutos e então lavamos o precipitado com $1 \mathrm{ml}$ de etanol 70\%. Era realizada uma última centrifugação a $12.000 \mathrm{rpm}$ por 5 minutos e o DNA precipitado era deixado à temperatura ambiente por alguns minutos para secar, sendo então ressuspendido em $50 \mu l$ de TE contendo $20 \mu \mathrm{g} / \mathrm{ml}$ de RNase A (Invitrogen, EUA). Esta solução era então mantida a 50 ${ }^{\circ} \mathrm{C}$ por 30 minutos e estocada a $4{ }^{\circ} \mathrm{C}$ até o momento do uso.

\subsection{Conjugação de cepas de $C$. crescentus com $E$. coli S17-1 contendo o promotor do gene rho fusionado ao gene repórter lacZ}

A bactéria E. coli S17-1 contendo o promotor do gene rho fusionado ao gene repórter lacZ no vetor pRKLacZ290 (Gober e Shapiro, 1992) foi cedida pelo laboratório da Prof. Dra. Marilis do Valle Marques (Italiani e Marques, 2005). Esta bactéria foi então conjugada com as cepas NA1000, lexA, CC_3225 e RM20 e a seleção foi realizada pela marca de resistência do plasmídeo (tetraciclina) e ácido nalidíxico. 


\subsection{Medida da atividade de $\beta$-galactosidase}

As cepas NA1000 e lexA contendo o plasmídeo descrito acima foram crescidas por 16 horas a $30^{\circ} \mathrm{C}$ na presença de tetraciclina. As culturas foram então diluídas para D.0.600nm 0,1 e incubadas sob agitação a $30{ }^{\circ} \mathrm{C}$ até que atingissem D.0.600nm 0,5. Neste momento elas foram submetidas ao ensaio, que foi modificado a partir de Miller (1992) e adaptado para $C$. crescentus. A densidade celular foi medida pela D.0.600nm antes do ensaio, e em seguida, 50 $\mu \mathrm{l}$ de cada cultura foram colocados em um microtubo contendo $800 \mu \mathrm{l}$ de Z-buffer $(60 \mathrm{mM}$ $\left.\mathrm{Na}_{2} \mathrm{HPO}_{4} .7 \mathrm{H}_{2} \mathrm{O}, 40 \mathrm{mM} \mathrm{NaH} \mathrm{PO}_{4} \cdot \mathrm{H}_{2} \mathrm{O}, 10 \mathrm{mM} \mathrm{KCl}, 1 \mathrm{mM} \mathrm{MgSO}{ }_{4} .7 \mathrm{H}_{2} \mathrm{O}\right), 2,88 \mu \mathrm{l}$ de $\beta-$ mercaptoetanol e $50 \mu \mathrm{l}$ de clorofórmio. Após agitação, os tubos eram incubados a $30^{\circ} \mathrm{C}$ por 5 minutos e então eram adicionados $200 \mu \mathrm{l}$ do indutor ONPG $(4 \mathrm{mg} / \mathrm{ml}$ em tampão fosfato: $60 \mathrm{mM} \mathrm{Na} 2 \mathrm{PO}_{4} .7 \mathrm{H}_{2} \mathrm{O}$ e $40 \mathrm{mM} \mathrm{NaH} \mathrm{PO}_{4} \cdot \mathrm{H}_{2} \mathrm{O}$ ); os microtubos eram novamente incubados a $30{ }^{\circ} \mathrm{C}$ por 5 minutos. A reação era então interrompida pela adição de $400 \mu \mathrm{l}$ de $\mathrm{NaCO}_{3} 1 \mathrm{M}$. A dosagem do sobrenadante era feita pela medida da D.0.420nm após centrifugação a $12.000 \mathrm{~g}$ por 5 minutos.

O cálculo da atividade de $\beta$-galactosidase era realizado seguindo a fórmula:

$$
U=\text { D.0.420nm X } 1000 / \text { D.0.600nm Xv Xt }
$$

Nesta equação, $U$ corresponde às unidades de $\beta$-galactosidade, $v$ ao volume de cultura utilizado em microlitros (no caso, 50) e t ao tempo de incubação a $30^{\circ} \mathrm{C}$ em minutos (no caso, 5).

\subsection{Extração de RNA total de $C$. crescentus}

A extração do RNA total de $C$. crecentus foi realizada utilizando o reagente Trizol (Invitrogen, EUA) e o protocolo cedido pelo fabricante com algumas alterações. 
Culturas em fase logarítmica de crescimento foram centrifugadas a $6.000 \mathrm{rpm}$ por 10 minutos, o sobrenadante descartado e o precipitado bacteriano restante foi ressuspendido em $1 \mathrm{ml}$ de Trizol ( $1 \mathrm{ml}$ de Trizol para 5 a $10 \mathrm{ml}$ de cultura em D.0.600nm 0,5). A mistura foi incubada a $65{ }^{\circ} \mathrm{C}$ por 10 minutos, e então foram acrescentados $200 \mu \mathrm{l}$ de clorofórmio; os tubos foram invertidos até que a mistura se tornasse translúcida e então mantidos a temperatura ambiente por 5 minutos. Centrifugamos a $14.000 \mathrm{rpm}$ por 15 minutos a $4{ }^{\circ} \mathrm{C}$, recuperamos a fase superior incolor (que contém o RNA) e a transferimos para um novo tubo; a este adicionamos $500 \mu \mathrm{l}$ de isopropanol e deixamos as amostras a $-20^{\circ} \mathrm{C}$ por mais de 16 horas para que a precipitação do RNA fosse mais eficiente. Centrifugamos a 14.000 rpm por 30 minutos a $4{ }^{\circ} \mathrm{C}$, descartamos o sobrenadante e lavamos o precipitado de RNA com etanol 75\%. Após uma última centrifugação a $14.000 \mathrm{rpm}$ por 5 minutos a $4{ }^{\circ} \mathrm{C}$, deixamos o RNA precipitado secar a temperatura ambiente por alguns minutos, ressuspendemos em 50 $\mu l$ de água MilliQ tratada com $0,1 \%$ de DEPC e incubamos por 10 minutos a $55{ }^{\circ} \mathrm{C}$ para facilitar a solubilização do RNA.

Os RNAs foram verificados através de géis de agarose $0,8 \%$ em tampão TBE $0,5 \mathrm{X}$ contendo brometo de etídeo com o auxílio do Image Quant 300 (GE Healthcare, EUA). A quantificação dos RNAs foi realizada através do espectrofotômetro NanoDrop 1000 (Thermo Scientific, EUA). Os RNAs foram estocados a $-80^{\circ} \mathrm{C}$ até o momento do uso.

\subsection{Síntese de cDNAs}

O RNAs obtidos com o protocolo descrito acima foram tratados com a RQ1 RNasefree DNase (Promega, EUA) seguindo os passos do protocolo do fornecedor. A quantidade de RNA tratada variou entre 500 e 1000 ng. O RNA foi utilizado para a reação de síntese de cDNA com o auxílio do kit High-Capacity cDNA Reverse Transcription (Applied Biosystems, EUA). Os cDNAs obtidos foram quantificados através do espectrofotômetro NanoDrop 1000 (Thermo Scientific, EUA) e estocados $\mathrm{a}-20^{\circ} \mathrm{C}$. 


\subsection{RT-PCR Quantitativa}

Os níveis de expressão relativa dos genes pertencentes ao regulon SOS foram determinados por ensaios de RT-PCR quantitativo comparando os níveis de expressão na cepa selvagem NA1000 com o da cepa lexA. As reações foram realizadas com o reagente SYBR Green PCR Master Mix (Applied Biosystems, EUA) e 200 ng de cDNA de NA1000 e lexA, e então analisadas no sistema ABI-7500 Real-Time (Applied Biosystems, EUA). Os níveis de expressão relativa foram calculados segundo o protocolo sugerido por Pfaffl (2001), utilizando os genes rho ou CC_3130 como controles endógenos.

\subsection{Funcionalidade in vivo do operador SOS}

\subsubsection{Mutagênese sítio dirigida do promotor de imuA}

A mutagênese sítio dirigida do promotor de imuA foi realizada através de reações de PCR com iniciadores contendo as mutações desejadas. Reações de PCR utilizando a enzima Pfx (Invitrogen, EUA) com um iniciador mutagênico e um iniciador externo (p3213re e pimuAmutfow; p3213fo e pimuAmutrev; o primeiro oligonucleotídeo de cada conjunto é o externo e o segundo é o mutagênico) foram realizadas para amplificar os fragmentos do promotor de imuA contendo as mutações desejadas (duas substituições de bases). Os dois fragmentos foram então utilizados em uma nova reação de PCR apenas com os oligonucleotídeos externos para amplificar um único fragmento contendo a mutação desejada. Este produto foi então clonado no pGEM-T Easy (Promega, EUA) e seqüenciado para garantir que apenas as mutações desejadas estavam presentes. O promotor mutado foi então subclonado no vetor pRKLacZ290 (Gober e Shapiro, 1992) criando uma fusão transcricional com o gene repórter lacZ. Esta construção foi então transferida para as cepas 
NA1000 e lexA através de conjugação mediada pela $E$. coli S17-1 e submetidas às seleções adequadas.

\subsubsection{Medida da atividade de 6-galactosidase}

As cepas NA1000 e lexA contendo o plasmídeo com o promotor mutado de imuA em fusão transcricional com lacZ ou o plasmídeo com o promotor selvagem de imuA (Galhardo et al., 2005) foram crescidas por 16 horas a $30{ }^{\circ} \mathrm{C}$. As culturas foram então diluídas para D.0.600nm 0,1 e incubadas sob agitação a $30{ }^{\circ} \mathrm{C}$ até que atingissem D.0.600nm 0,5. Parte destas culturas foi irradiada com $45 \mathrm{~J} / \mathrm{m}^{2}$ de luz UVC; as células tratadas e não tratadas foram então incubadas por 60 minutos a $30^{\circ} \mathrm{C}$ sob agitação constante, sendo em seguida submetidas ao ensaio como descrito no item 3.15.

\subsubsection{Determinação do início de transcrição dos genes imuA e CC_2272}

RNAs de culturas exponenciais de lexA foram extraídos com auxílio de Trizol conforme descrito no item 3.16. Os experimentos de 5' Race (5' Rapid amplification of cDNA ends) foram realizados com o auxílio do kit 5' Race System (Invitrogen, EUA) da seguinte forma: três oligonucleotídeos (GSP1 a GSP3) foram desenhados para cada gene. GSP1 foi utilizado para a síntese do cDNA específico do gene em questão; uma cauda de poli-T era adicionada ao término $5^{\prime}$ do cDNA com o auxílio de desoxinucleotidil transferase terminal (Tdt). Esta reação foi utilizada como molde para um PCR com os oligonucleotídeos GSP2 e 3'RACE. Um PCR nested foi então realizado com os oligonucleotídeos GSP3 e AUAP para aumentar a especificidade, sendo os produtos de amplificação clonados no vetor pGEM-T Easy para posterior seqüenciamento. Nove clones foram seqüenciados para as reações de 5' Race de CC_2272 e 10 clones para as reações de 5’ Race de imuA. O início de transcrição foi então identificado como a base adjacente a cauda de poli-T mais representada dentre os 
clones seqüenciados, o que significou $70 \%$ para os clones de imuA e 66,7\% para os clones de CC_2272.

\subsection{Ensaios de sobrevivência}

Culturas das cepas NA1000 e dos mutantes em questão de $C$. crescentus crescidas por aproximadamente 16 horas a $30^{\circ} \mathrm{C}$ a partir de uma única colônia eram diluídas para D.0.600nm 0,1 em meio PYE e mantidas sob constante agitação a mesma temperatura até que atingissem D.O.600nm 0,5. Uma alíquota das culturas era então separada para ser o controle não tratado e o restante era submetido ao tratamento com luz UVC ou $\mathrm{H}_{2} \mathrm{O}_{2}$ nas doses e concentrações adequadas. Todas as alíquotas eram então diluídas seriadamente e plaqueadas em meio PYE para a aferição das unidades formadora de colônia. As placas eram mantidas por 2 dias a $30^{\circ} \mathrm{C}$, e então o número de colônias era contado. O percentual de sobrevivência era calculado em relação ao número de colônias obtidas com o plaqueamento da cultura não tratada.

\subsection{Mutagênese aleatória da cepa lexA}

\subsubsection{Mutagênese aleatória de lexA utilizando o tranposon Mariner}

A bactéria E. coli S17-1 contendo o plasmídeo pHPV414, que possui o transposon Mariner (Viollier et al., 2004), foi cedida pelo laboratório da Dra. Kathleen Ryan. Esta bactéria foi então conjugada com a cepa lexA, e a seleção foi realizada pela marca de resistência do transposon (canamicina) e ácido nalidíxico. As colônias que surgiam após esta seleção eram então submetidas ao ensaio de natação. 


\subsubsection{Ensaio de natação}

A avaliação da capacidade natatória de $C$. crescentus foi realizada em placas contendo meio PYE denominado soft agar, que contem apenas 0,3\% de agar. Colônias crescidas em placas de PYE contendo $1,5 \%$ de agar foram transferidas com o auxílio de palitos de dente para a placa de PYE soft agar e sua capacidade natatória foi analisada após dois dias de crescimento a $30^{\circ} \mathrm{C}$. A placa foi fotografada com o auxílio do Image Quant 300 .

\subsection{Determinação da freqüência de mutação espontânea}

Uma colônia de cada clone desejado era inoculada em meio PYE e cultivada a $30{ }^{\circ} \mathrm{C}$ por 48 horas sob agitação constante. Essas culturas eram diluídas seriadamente e plaqueadas em meio PYE sólido para a aferição do número de unidades formadoras de colônias; e em meio PYE sólido contendo $50 \mu \mathrm{g} / \mathrm{ml}$ do antibiótico rifampicina. As placas eram mantidas por 2 dias a $30^{\circ} \mathrm{C}$.

A resistência a rifampicina é geralmente pouco difundida dentro de uma população bacteriana. Este antibiótico se liga a RNA polimerase bacteriana, impondo um sério bloqueio à transcrição; mutações no gene $r p o B$, que codifica a subunidade $\beta$ da RNA polimerase, são capazes de tornar as células resistentes à rifampicina (Garibyan et al., 2003). Desta forma, mutações no gene $r p o B$ são utilizadas neste experimento como um meio de aferir a freqüência de mutação espontânea de uma dada cepa. A freqüência é calculada pela relação entre o número de colônias resistentes ao antibiótico e o número total de colônias plaqueadas. Esse valor é então comparado com aquele da cepa selvagem, NA1000. 


\subsection{Análise filogenética}

As seqüências dos genes foram obtidas a partir do National Center for Biotechnology Information GenBank. As seqüências protéicas foram alinhadas utilizando o programa de alinhamento de seqüências múltiplas ClustalX (Thompson et al., 1997) com ajustes manuais no programa Genedoc v. 2.6.001. Somente posições alinhadas sem ambigüidade (excluindo aqui regiões pouco conservadas e contendo gaps) foram utilizadas. Árvores filogenéticas não enraizadas foram geradas para cada grupo de proteínas homólogas dos alinhamentos de seqüência usando o programa PHYLIP versão 3.5. As análises de distância foram realizadas utilizando o método de neighbor-joining no PHYLIP, com o modelo de matriz de distância PAM. O suporte de bootstrap (reamostrado 500 vezes) foi calculado e a árvore de consenso estrito foi construída. A árvore de consenso obtida foi observada através do programa TreeView (Page, 1996).

\subsection{Sincronização de culturas de $C$. crescentus}

O procedimento de sincronização consiste no isolamento da fração de células móveis de uma cultura de $C$. crescentus através de um gradiente de densidade utilizando a sílica coloidal Percoll (GE Healthcare, EUA).

Para tanto, iniciamos uma cultura a partir de uma colônia da cepa desejada de $C$. crescentus em $2 \mathrm{ml}$ de meio PYE, mantendo sob agitação a $30{ }^{\circ} \mathrm{C}$ por 16 horas. Cerca de $20 \mu \mathrm{l}$ deste primeiro pré-inóculo eram então transferidos para $2 \mathrm{ml}$ de meio mínimo $\mathrm{M} 2$ acrescido de glicose (chamado a partir daqui de M2G: $20 \mathrm{mM} \mathrm{Na}_{2} \mathrm{HPO}_{4}, 20 \mathrm{mM} \mathrm{KH}_{2} \mathrm{PO}_{4}, 9,3 \mathrm{mM} \mathrm{NH}_{4} \mathrm{Cl}$, 0,5 mM MgSO $4,0,5 \mathrm{mM} \mathrm{CaCl}_{2}, 1$ um $\mathrm{FeSO}_{4}, 0,2 \%$ glicose) e incubado sob agitação por mais 16 horas a $30^{\circ} \mathrm{C}$. Este segundo pré-inóculo foi então transferido para $50 \mathrm{ml}$ de meio $\mathrm{M} 2 \mathrm{G}$ e mantido sob agitação constante a $30^{\circ} \mathrm{C}$. Este último inóculo deve ser feito de tal forma que, no momento do experimento, a cultura esteja em fase logarítmica de crescimento, pois é neste período que a proporção de células móveis é maior (Iba et al., 1975). 
A cultura foi então centrifugada a $6.000 \mathrm{rpm}$ por 10 minutos a $4{ }^{\circ} \mathrm{C}$, o sobrenadante descartado e o precipitado bacteriano foi ressuspendido em $1 \mathrm{ml}$ de $\mathrm{M} 2$ sais $1 \mathrm{X}(20 \mathrm{mM}$ $\mathrm{Na}_{2} \mathrm{HPO}_{4}, 20 \mathrm{mM} \mathrm{KH}_{2} \mathrm{PO}_{4}, 9,3 \mathrm{mM} \mathrm{NH}_{4} \mathrm{Cl}$ ) gelado e transferido para um microtubo. A mistura foi centrifugada a $13.000 \mathrm{rpm}$ por 2 minutos, novamente o sobrenadante foi descartado e 0 precipitado foi mantido em gelo e ressuspendido em $700 \mu \mathrm{l}$ de $\mathrm{M} 2$ sais $1 \mathrm{X}$. Adicionamos 700 $\mu \mathrm{l}$ de Percoll, invertemos para garantir a homogeneização e centrifugamos a 10.000 rpm por 18 minutos a $4{ }^{\circ} \mathrm{C}$. Após esta centrifugação, observamos a seguinte configuração no microtubo: uma banda superior de células talo, um gradiente de células em diferentes etapas da fase pré-divisional, uma banda de células móveis e uma porção final de Percoll livre. Cuidadosamente aspiramos e descartamos a banda de células talo e a fase de prédivisionais, recuperamos a banda de células móveis e a transferimos para um novo microtubo. Realizamos então duas lavagens com $1 \mathrm{ml}$ de $\mathrm{M} 2$ sais $1 \mathrm{X}$ para remover o excesso de Percoll, centrifugando a $8.000 \mathrm{rpm}$ por 3 minutos a $4{ }^{\circ} \mathrm{C}$ após cada lavagem. $\mathrm{O}$ precipitado final foi então ressuspendido em volume adequado meio M2G para os experimentos determinados. Colocando estas células em cultura podemos, portanto, observar a progressão de um ciclo celular.

\subsection{Avaliação do ciclo celular através de citometria de fluxo}

Após a sincronização, $300 \mu \mathrm{l}$ de culturas de cepas de $C$. crescentus submetidas ou não a irradiação com luz UVC foram coletadas em tempos crescentes e adicionadas a $700 \mu \mathrm{l}$ de etanol $100 \%$ para a fixação das células. Estas células fixadas foram armazenadas a $4^{\circ} \mathrm{C}$ até $\mathrm{o}$ momento do processamento, que nunca excedeu o período de 3 a 4 semanas.

As células fixadas foram então centrifugadas a $6.000 \mathrm{rpm}$ por 2 minutos, 0 sobrenadante foi descartado e o precipitado foi ressuspendido em solução fresca de FCM (20 mM Tris.Cl pH 7,5, 150 mM NaCl, $8 \mu \mathrm{M}$ Sytox Green (Molecular Probes, EUA), $2 \mu \mathrm{g} / \mathrm{ml}$ RNase A). As amostras foram armazenadas por 16 horas a $4{ }^{\circ} \mathrm{C}$ envoltas em papel alumínio para inibir a perda de fluorescência do corante. A análise foi feita por citometria de fluxo, utilizando-se o citômetro Guava PCA-96 System (Millipore, EUA). 


\subsection{Detecção e quantificação de lesões CPD em DNAs genômicos de C. crescentus}

\subsubsection{Calibração do método}

O método descrito aqui foi modificado a partir de Schuch et al. (2009). Basicamente o que fizemos foi utilizar uma enzima de reparo que reconhece especificamente dímeros de pirimidina ciclobutano (CPDs), clivando a ligação fosfodiéster no sitio da lesão e resultando no relaxamento de moléculas de DNA plasmidial superenoveladas (T4-endonuclease V, produzida no laboratório segundo Schuch, 2009), para quantificar o número destas lesões em um DNA de tamanho conhecido, a fim de poder extrapolar este valor para os dados obtidos com este mesmo DNA através de outro método de detecção de CPDs, o imuno slotblot utilizando anticorpos específicos.

\subsubsection{Quantificação de lesões CPD através de ensaio de relaxamento de plasmídeo}

Para estes experimentos utilizamos o plasmídeo pCMUT (Schuch et al., 2009) em tampão $T E$, que foi separado em três alíquotas de $30 \mu \mathrm{l}(100 \mathrm{ng} / \mu \mathrm{l})$ e submetidas a diferentes irradiações em placa de petri de $30 \mathrm{~mm}$ : uma alíquota controle não irradiada, uma irradiada com $15 \mathrm{~J} / \mathrm{m}^{2}$ de UVC e outra irradiada com $150 \mathrm{~J} / \mathrm{m}^{2}$ de UVC. Brevemente, 200 ng de cada uma destas amostras foram incubados por 30 minutos a $37{ }^{\circ} \mathrm{C}$ em tampão de reação (50 $\mathrm{mM} \mathrm{KH}_{2} \mathrm{PO}_{4}, 100 \mathrm{mM} \mathrm{NaCl}, 1 \mathrm{mM}$ EDTA, $1 \mathrm{mM} \mathrm{DTT}, 0,1 \mathrm{mg} / \mathrm{ml} \mathrm{BSA}$ ) com ou sem 70 ng de T4-endonuclease V. Estas amostras foram então aplicadas em um gel de agarose $0,6 \%$ em TBE 1 X contendo brometo de etídeo, sendo quantificadas as bandas resultantes da corrida com o Image Quant 300.

O número de sítios sensíveis a enzima por kbp corresponde a uma distribuição de Poisson (Ribeiro et al., 1992), e pode ser calculado através da seguinte fórmula:

$$
X=-\ln (1,4 \times \mathrm{FI} / 1,4 \times \mathrm{FI}+\mathrm{FII}) / 1,8
$$


O cálculo obedece à determinação de freqüência de moléculas sem lesão alguma (DNA plasmidial superenovelado). Nesta equação, $X$ é o número de quebras na molécula de DNA plasmidial por kbp, FI representa a intensidade de fluorescência medida na banda de DNA superenovelada (forma I), FII representa a intensidade de fluorescência medida na banda de DNA circular relaxado (forma II), 1,4 é o fator aplicado para corrigir o excesso de fluorescência devido à maior capacidade de ligação de brometo de etídeo ao DNA na forma circular relaxada e 1,8 é o tamanho aproximado do vetor pCMUT em kbp.

Foi possível então o estabelecimento do número de CPDs por kbp obtidos com cada uma das doses de UVC testadas.

\subsubsection{Detecção de lesões CPD por ensaios de imuno slot-blot}

As alíquotas de pCMUT tratadas no item acima também foram utilizadas para a detecção das lesões CPDs através da utilização de anticorpo específico. Obtivemos também DNAs genômicos das cepas de $C$. crescentus em questão após a sincronização das mesmas e irradiação com 15 ou $150 \mathrm{~J} / \mathrm{m}^{2}$ de UVC (realizada no tempo 0).

Para que os resultados obtidos aqui fossem comparáveis aos obtidos no item anterior, novamente $200 \mathrm{ng}$ de PCMUT ou do DNA de interesse submetido aos diferentes tratamentos foram misturados a 800 ng de DNA de esperma de salmão (totalizando $1 \mu \mathrm{g}$ de DNA), desnaturados a $100{ }^{\circ} \mathrm{C}$ por 10 minutos e transferidos imediatamente para o gelo. Esses DNAs foram transferidos para uma membrana de nitrocelulose de $11 \mathrm{~cm} \times 13 \mathrm{~cm}$, que foi então incubada por 15 minutos em SSC 5 X (750 mM NaCl, $75 \mathrm{mM}$ citrato de sódio) a temperatura ambiente. A membrana foi deixada a temperatura ambiente para secar por alguns minutos e incubada a $80^{\circ} \mathrm{C}$ por 2 horas; ela foi então bloqueada em PBS 1 X (137 mM $\mathrm{NaCl}, 2,7 \mathrm{mM} \mathrm{KCl}, 4,3 \mathrm{mM} \mathrm{Na}_{2} \mathrm{HPO}_{4} .7 \mathrm{H}_{2} \mathrm{O}, 1,4 \mathrm{mM} \mathrm{KH}_{2} \mathrm{PO}_{4}$ ) contendo $5 \%$ de leite em pó desnatado por aproximadamente 16 horas a $4{ }^{\circ} \mathrm{C}$ sob agitação leve. A membrana foi em seguida incubada com o anticorpo primário anti-CPD (Medical and Biological Laboratories Ltda., Japão) diluído 1 : 2000 em solução de bloqueio por 3 horas a temperatura ambiente sob agitação constante. Após este período, o anticorpo primário foi removido e armazenado 
a $-20{ }^{\circ} \mathrm{C}$ (os anticorpos nestes experimentos podem ser reutilizados por até 3 vezes) e a membrana foi lavada 6 vezes por 5 minutos em PBS 1 X contendo 0,1\% de Tween 20, sendo então incubada com o anticorpo secundário (anti-camundongo conjugado com HRP, do inglês Horseradish peroxidase, GE Healthcare, EUA) também diluído a $1: 2000$ por 2 horas a temperatura ambiente. Após a incubação, o anticorpo secundário foi também armazenado a $-20^{\circ} \mathrm{C}$ e a membrana lavada com descrito anteriormente.

A membrana foi tratada como reagente de quimioluminescência Amersham ECL Western Blotting Detection (GE Healthcare, EUA): o sinal luminoso é gerado pela oxidação do luminol presente em uma das soluções do kit pela enzima HRP, conjugada ao anticorpo secundário. A quantificação foi realizada com o auxílio do Image Quant 300.

A partir destes dois experimentos pudemos então determinar a relação entre a intensidade das bandas obtidas com o experimento com o anticorpo anti-CPD com o número de quebras (e, portanto, de CPDs) por pares de bases obtidos com o experimento de relaxamento de plasmídeo.

\subsection{Experimentos de fotorreativação}

Para os testes iniciais de fotorreativação em C. crescentus, as cepas NA1000 e uvrA foram cultivadas em meio PYE por 16 horas a $30{ }^{\circ} \mathrm{C}$ sob agitação constante. Estes préinoculos foram então diluídos para D.0.600 $\mathrm{nm}$ 0,1 e cultivados ate que atingissem D.0.600 nm 0,5 . Neste momento foram separadas em três alíquotas: a primeira foi irradiada com 150 $\mathrm{J} / \mathrm{m}^{2}$ de UVC e mantida no escuro; a segunda foi submetida à irradiação com $150 \mathrm{~J} / \mathrm{m}^{2}$ de UVC e então fotorreativada com luz branca por duas lâmpadas Philips 15 W (emissão entre 365 e $700 \mathrm{~nm}$ ) por 15, 30 ou 45 minutos ou com luz UVA (Osram Ultramed FDA KY10s 1000 W filtrada com o filtro Schott BG39 $3 \mathrm{~mm}$ de espessura (Schott Glass, Alemanha)) por 15, 30 ou 45 minutos; e a terceira, que era a amostra controle, foi apenas mantida no escuro. As três amostras foram, então, diluídas, plaqueadas e mantidas a $30{ }^{\circ} \mathrm{C}$ por 2 dias para a aferição das unidades formadoras de colônia, e também submetidas à extração de DNA genômico para a realização de ensaios de slot-blot para a detecção de lesões CPDs. 


\section{RESULTADOS}

\subsection{Determinação do regulon SOS}

\subsubsection{Identificação dos genes regulados por LexA}

Nosso primeiro objetivo foi a construção de uma cepa deficiente para o gene lexA, o repressor do regulon SOS. A JAL CC_1902, que codifica a proteína LexA, possui 705 nucleotídeos, sendo que a cepa lexA, obtida por recombinação homóloga (ver item 3.10.1 dos Materiais e Métodos) possui apenas os 96 nucleotídeos iniciais somados aos 42 finais, mais regiões flanqueadoras. Após a confirmação molecular da mutação através de PCR (resultados não mostrados), estudamos algumas características dessa cepa mutante.

Esta cepa se mostrou viável, mas com severa deficiência de crescimento (Figura 7).
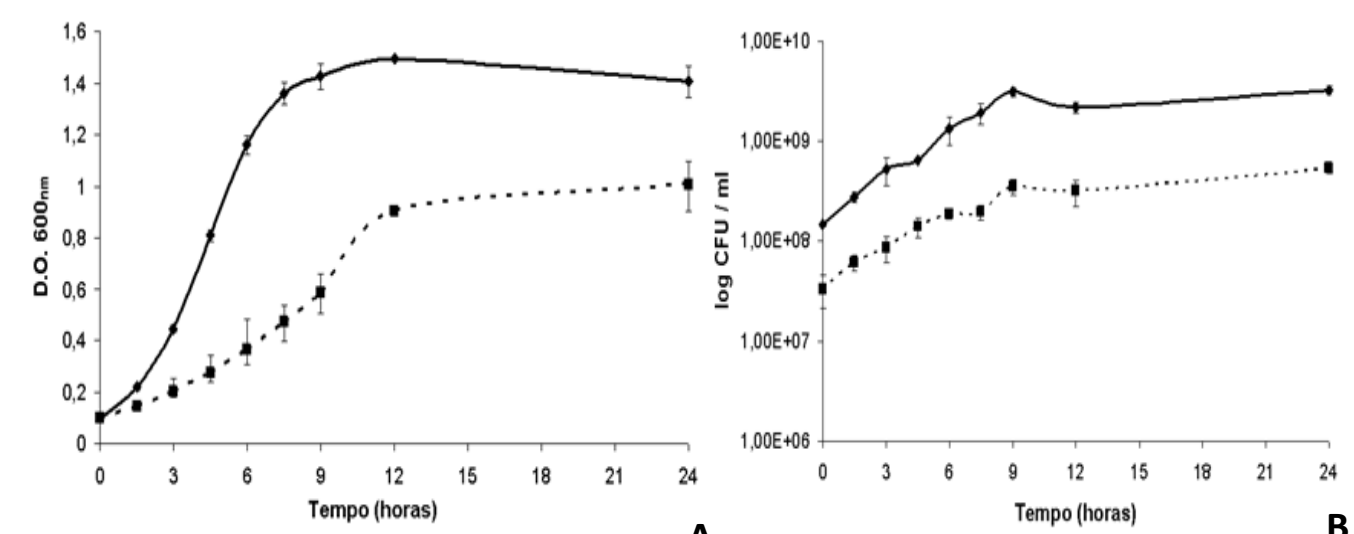

Figura 7 - Curvas de crescimento das cepas NA1000 e lexA. Curvas determinadas através da densidade ótica da cultura bacteriana $(A)$ e contagem do número de unidades formadoras de colônias (B). Linha cheia: cepa selvagem NA1000; linha pontilhada: lexA. As figuras representam médias e desvios padrão de três experimentos independentes.

Esse crescimento reduzido da cepa lexA provavelmente se deve a um defeito na divisão celular, o que pode ser inferido a partir do fenótipo filamentado das células quando observadas (Figura 8). A complementação desta cepa com o gene lexA selvagem recupera a 
morfologia original, indicando, portanto, que o fenótipo filamentoso realmente se deve a deleção do gene em questão.
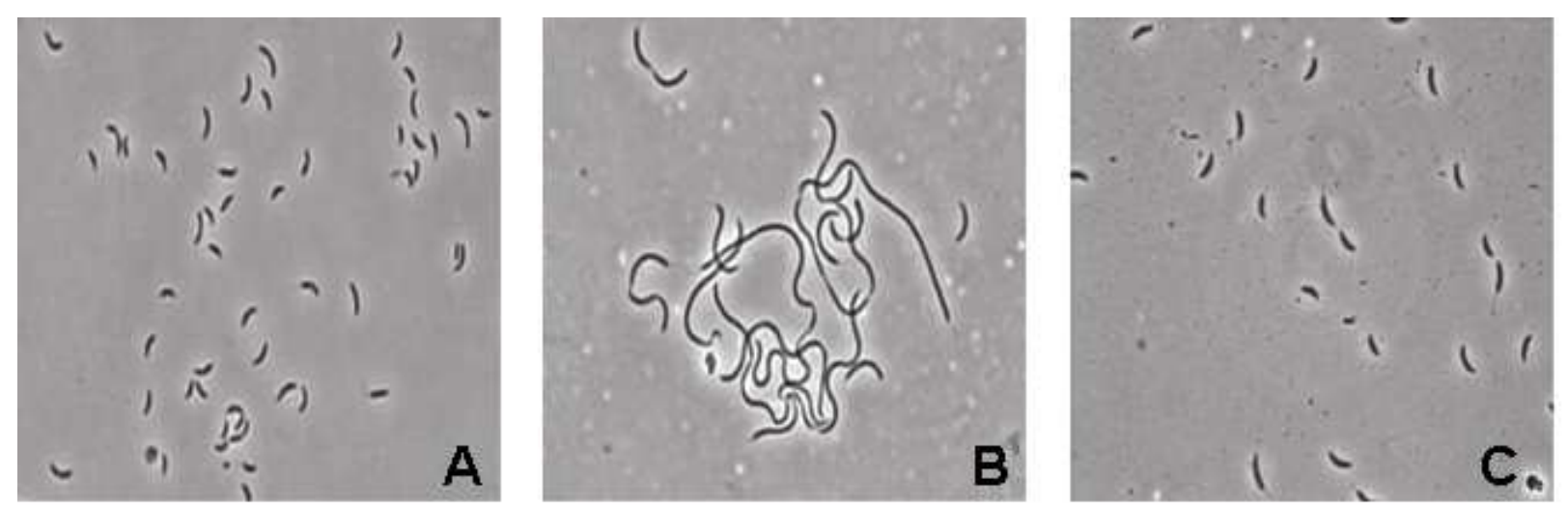

Figura 8 - A cepa lexA de C. crescentus possui fenótipo filamentoso. Microscopia ótica de cepas NA1000 (A), lexA (B) e lexA complementada com um vetor de baixas cópias contendo o gene lexA selvagem (C) utilizando uma objetiva de $100 x$ de aumento.

A análise da quantidade de genomas da cepa lexA foi realizada através de citometria de fluxo, com a utilização de intercalante de DNA capaz de ser excitado pelo laser do citômetro. Dessa forma, podemos determinar o conteúdo de DNA em cada célula de uma dada amostra. Os resultados indicados na figura 9 revelam que lexA possui vários genomas por célula (se comparado a uma cultura de NA1000, que apresenta, no máximo, dois genomas por célula). A deficiencia na divisão celular de lexA se deve, portanto, a outro mecanismo que não o simples bloqueio da replicação do material genético, como será discutido adiante. 

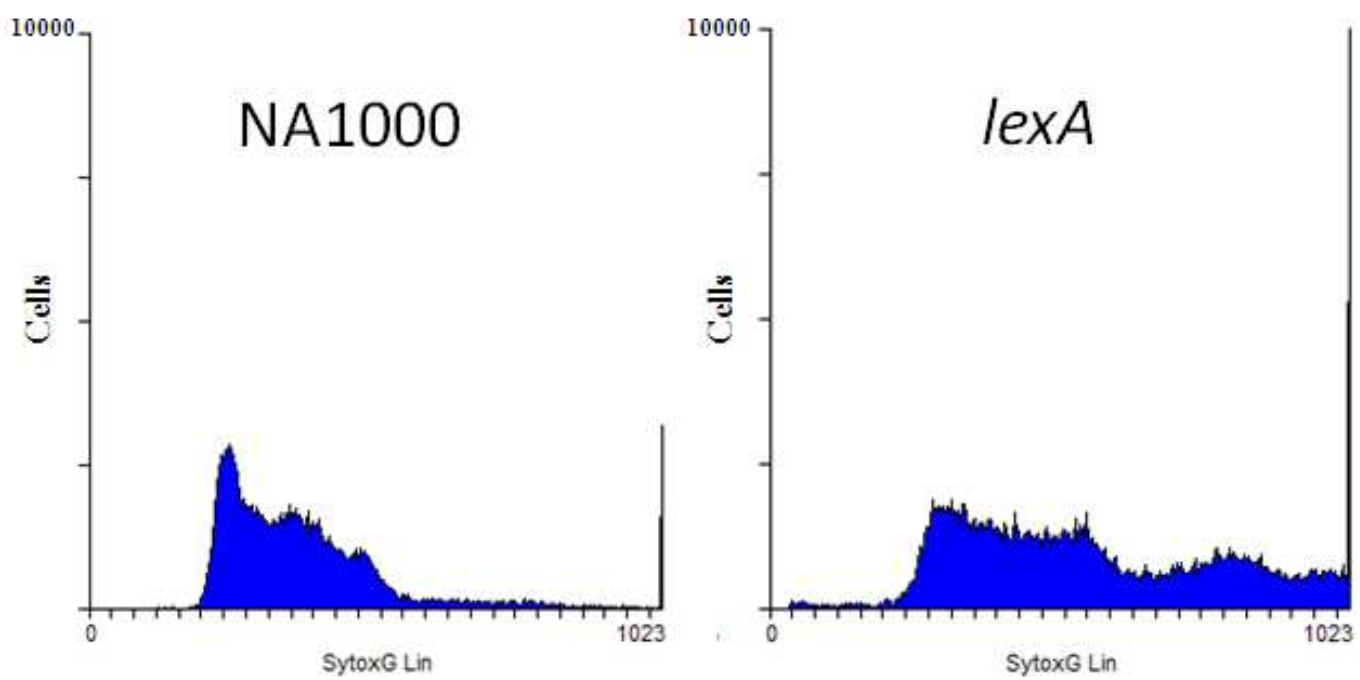

Figura 9 - $\quad$ Conteúdo de DNA das cepas NA1000 e lexA de C. crescentus. Eixo das ordenadas: contagem de células; eixos das abcissas: fluorescência verde (escala linear), que indica a quantidade de DNA por célula.

Esta cepa foi então empregada como uma importante ferramenta para a determinação do regulon SOS neste organismo uma vez que, na ausência de LexA, os genes pertencentes ao regulon não se encontram mais reprimidos.

A determinação inicial dos genes que potencialmente pertenceriam ao regulon SOS em C. crescentus foi realizada in silico pelo Dr. Apuã Cesar de Miranda Paquola. Brevemente, foi realizada uma busca pelo motivo de ligação da proteína LexA no genoma completo de $C$. crescentus, a denominada caixa SOS. A busca inicial utilizou como parâmetro genes sabidamente regulados por LexA em outros organismos e que possuíam ortólogos no genoma de $C$. crescentus (lexA, recA e recN), além de imuA e uvrA, que comprovadamente fazem parte deste regulon neste organismo (Galhardo et al., 2005). As JALs localizadas após regiões com alta pontuação na análise acima foram então confirmadas por ensaios de RTPCR quantitativo, sendo que os genes com expressão relativa superior a duas vezes na cepa lexA foram incluídos em uma nova iteração de busca pelo motivo de ligação do repressor.

Desta forma, pudemos primeiramente confirmar que o motivo de ligação de LexA em C. crescentus está de acordo com o encontrado anteriormente em outras alfaproteobactérias, descrito como $\mathrm{GTTCN}_{7} \mathrm{GTTC}$ (Erill et al., 2004). Além disso, encontramos inicialmente 28 caixas SOS no genoma com elevada pontuação (score, obtido pela análise de bioinformática) e localizadas nas proximidades de JALs de forma consistente com uma 
repressão transcricional. Nesta primeira etapa 44 JALs foram validadas com ensaios de RTPCR quantitativo comparando o nível de expressão na cepa lexA com o da selvagem NA1000. Dentre estas estavam 5 possíveis operons, sendo que todos os genes possivelmente cotranscritos foram testados (CC_1926-CC_1927, CC_2332-CC_2333, CC_2879-CC_2880CC_2881, CC_3036-CC_3037-CC_3038 e CC_3238-CC_3237-CC_3236, o operon ruvCAB). É também importante ressaltar que sempre que uma caixa SOS se localizava na região nãocodificante entre duas JALs, ambas eram testadas para determinar se um mesmo sítio de ligação a LexA era capaz de reprimir ambos os genes; este foi o caso para as JALs CC_1086 e CC_1087, CC_1531 e CC_1532, CC_1927 e CC_1928, CC_2589 e CC_2590, CC_2878.1 e CC_2879, CC_3038 e CC_3039, e CC_0382 e CC_0383.

Para normalizar os dados de expressão relativa utilizando o método descrito em Pfaffl, 2001, utilizamos como controle endógeno o gene rho (CC_3760). Ensaios de $\beta$ galactosidase utilizando o promotor de rho fusionado ao gene repórter lacZ indicaram que este gene não é induzido na cepa lexA em relação à cepa selvagem, como podemos observar na tabela 4 abaixo.

Tabela 4 - Unidades de $\beta$-galactosidase obtidas a partir do promotor do gene rho nas cepas NA1000 e lexA.

\begin{tabular}{lc}
\hline Cepa & Unidades de 6-galactosidase \\
\hline NA1000 & $923,34( \pm 411,8)$ \\
lexA & $932,9( \pm 193,5)$ \\
\hline
\end{tabular}

Os dados de expressão relativa, bem como a pontuação e posição da caixa SOS em relação ao códon de início anotado no genoma de $C$. crescentus estão na tabela 5 abaixo, classificados de acordo com os níveis de expressão. 
Tabela 5 - Genes identificados pela análise in silico como sendo parte do regulon sos em $C$. crescentus e comparação da expressão in vivo destes genes na cepa NA1000 e lexA - primeira avaliação.

(Continua)

\begin{tabular}{|c|c|c|c|c|c|}
\hline ORF & $\begin{array}{l}\text { Nome do gene / } \\
\text { anotação em C. } \\
\text { crecentus CB15 }\end{array}$ & Caixa SOS ou descrição & $\begin{array}{c}\text { Pontuação } \\
\text { da caixa } \\
\text { SOS }\end{array}$ & $\begin{array}{c}\text { Posição } \\
\text { da caixa } \\
\text { SOS }^{a}\end{array}$ & $\begin{array}{c}\text { Expressão } \\
\text { relativa } \\
\text { (lexA / } \\
\text { NA1000) }^{b}\end{array}$ \\
\hline CC_1902 & lexA & AATGTTCTCCTGGTGTTCC & 14.3 & -51 & $43.2 \pm 9.3$ \\
\hline CC_0627 & Proteína hipotética & AAAGTTCGCGTTATGTTCT & 18.8 & -9 & $40.3 \pm 11.8$ \\
\hline CC_3467 & $\begin{array}{l}\text { Proteína hipotética } \\
\text { conservada }\end{array}$ & & 13.6 & -20 & $37.5 \pm 10.5$ \\
\hline CC_3518 & $\begin{array}{l}\text { Proteína hipotética } \\
\text { conservada }\end{array}$ & GATGTTCATGTATTGTTCT & 18.8 & -3 & $27.4 \pm 4.8$ \\
\hline CC_2332 & $\begin{array}{l}\text { Proteína hipotética } \\
\text { conservada }\end{array}$ & ATCGTTCTTGATTTGTTTCT & 18.7 & -13 & $18.8 \pm 6.8$ \\
\hline CC_2333 & $\begin{array}{l}\text { Proteína relacionada à } \\
\text { uracila DNA glicosilase }\end{array}$ & $\begin{array}{l}\text { Provável operon com } \\
\text { CC_2332 }\end{array}$ & & & $8.3 \pm 1.2$ \\
\hline CC_1926 & $\begin{array}{l}\text { dnaE / DNA polimerase } \\
\text { III, subunidade alfa }\end{array}$ & $\begin{array}{l}\text { Provável operon com } \\
\text { CC_1926 }\end{array}$ & & & $1.6 \pm 0.6$ \\
\hline CC_1927 & Proteína hipotética & $\begin{array}{l}\text { CATATTCCGGTTTTGTTCT } \\
\text { AGATTTCTTGTTTTGTTCC } \\
\text { TCTGTTCACAAGATGTTCC }\end{array}$ & $\begin{array}{l}16.4 \\
11.4 \\
11.1\end{array}$ & $\begin{array}{l}-165 \\
-181 \\
-147\end{array}$ & $17.7 \pm 6.2$ \\
\hline CC_3213 & $\begin{array}{l}\text { imuA (inducible } \\
\text { mutagenesis protein A), } \\
\text { em operon com ImuB } \\
\text { (DNA polimerase família } \\
\text { Y) e DnaE2 (DNA } \\
\text { polimerase família C) }\end{array}$ & CATGTTCCACTTTTGTTCT & 17.9 & -73 & $16.2 \pm 4.7$ \\
\hline CC_2272 & $\begin{array}{l}\text { Proteína da família da } \\
\text { Endonuclease III }\end{array}$ & AATGTTCTTGTTATGTTCT & 23.2 & -26 & $14.7 \pm 3.1$ \\
\hline CC_3424 & $\begin{array}{l}\text { Proteína hipotética } \\
\text { conservada }\end{array}$ & AATGTTCCTGAATTGTTCT & 20.7 & -26 & $13.62 \pm 5.5$ \\
\hline CC_1330 & $\begin{array}{l}\text { Proteína com domínio } \\
\text { radical SAM }\end{array}$ & TATGTTCTTGTTATGTTCG & 20.6 & -33 & $11.7 \pm 3$ \\
\hline CC_1054 & Proteína hipotética & TTTGTTCTCGGCTTGTTCT & 16.3 & -3 & $11.3 \pm 5.5$ \\
\hline CC_2040 & $\begin{array}{l}\text { RNA helicase } \\
\text { dependente de ATP, } \\
\text { família DEAD/DEAH }\end{array}$ & CATGTTCGCAAGATGTTCC & 14.0 & -24 & $9.1 \pm 3.4$ \\
\hline CC_1087 & $\begin{array}{l}\text { recA / recombinação de } \\
\text { DNA }\end{array}$ & & 15.5 & -114 & $9.0 \pm 1.5$ \\
\hline
\end{tabular}


Tabela 5 - Genes identificados pela análise in silico como sendo parte do regulon SOS em $C$. crescentus e comparação da expressão in vivo destes genes na cepa NA1000 e lexA - primeira avaliação.

(Continuação)

\begin{tabular}{|c|c|c|c|c|c|}
\hline ORF & $\begin{array}{l}\text { Nome do gene / } \\
\text { anotação em C. } \\
\text { crecentus CB15 }\end{array}$ & Caixa SOS ou descrição & $\begin{array}{c}\text { Pontuação } \\
\text { da caixa } \\
\text { SOS }\end{array}$ & $\begin{array}{c}\text { Posição } \\
\text { da caixa } \\
\text { sos }^{a}\end{array}$ & $\begin{array}{c}\text { Expressão } \\
\text { relativa } \\
\text { (lexA / }^{\text {NA1000) }}{ }^{b}\end{array}$ \\
\hline CC_2879 & Proteína hipotética & CATGTTCTGACTATGTTCC & 14.3 & +56 & $8.0 \pm 1.6$ \\
\hline CC_2880 & Proteína hipotética & $\begin{array}{l}\text { Provável operon com } \\
\text { CC_2879 }\end{array}$ & & & $9.74 \pm 3.7$ \\
\hline CC_2881 & $\begin{array}{l}\text { uvrC / exonuclease } A B C \text {, } \\
\text { subunidade } C\end{array}$ & $\begin{array}{l}\text { Provável operon com } \\
\text { CC_2879 }\end{array}$ & & & $1.7 \pm 0.3$ \\
\hline CC_3038 & $\begin{array}{l}\text { Proteína hipotética } \\
\text { conservada }\end{array}$ & AATGTTCCTATAATGTTCT & 21.5 & -160 & $5.3 \pm 0.8$ \\
\hline CC_3037 & $\begin{array}{l}\text { Proteína hipotética } \\
\text { conservada }\end{array}$ & $\begin{array}{lll}\text { Provável operon com } \\
\text { CC_3038 }\end{array}$ & & & $7.7 \pm 1.9$ \\
\hline CC_3036 & Proteína hipotética & $\begin{array}{l}\text { Provável operon com } \\
\text { CC_3038 }\end{array}$ & & & $7.3 \pm 1.2$ \\
\hline CC_3039 & Proteína hipotética & AATGTTCCTATAATGTTCT & 21.5 & -159 & $4.4 \pm 0.2$ \\
\hline CC_3356 & Proteína hipotética & CATGTTCTCGTATTGTTCG & 18.1 & -52 & $6.3 \pm 2.5$ \\
\hline CC_1531 & Proteína hipotética & $\begin{array}{l}\text { ATTGTTCTTGATATGTTCC } \\
\text { TATGTTCCAACTTCGTTTG }\end{array}$ & $\begin{array}{l}20.2 \\
11.3\end{array}$ & $\begin{array}{l}-31 \\
-20\end{array}$ & $5.9 \pm 1.1$ \\
\hline CC_1983 & recN & GATGATCCCGTTTCGTTCC & 11.9 & -56 & $5.6 \pm 1.6$ \\
\hline CC_0140 & $\begin{array}{l}\text { comM / proteína de } \\
\text { competência ComM }\end{array}$ & AACGTTCGTTTTTCGTTCT & 15.7 & -72 & $4.7 \pm 0.1$ \\
\hline CC_0383 & Proteína hipotética & TATGTTCCTGAAAAGTTCT & 18.5 & -14 & $5.0 \pm 2.7$ \\
\hline CC_3238 & ruvC & CGCGTTCATCATGTGTTCT & 10.4 & +2 & $5.1 \pm 1.9$ \\
\hline CC_3237 & ruvA & $\begin{array}{l}\text { Provável operon com } \\
\text { CC_3238 }\end{array}$ & & & $5.0 \pm 0.8$ \\
\hline CC_3236 & $\operatorname{ruv} B$ & $\begin{array}{l}\text { Provável operon com } \\
\text { CC_3238 }\end{array}$ & & & $3.4 \pm 0.4$ \\
\hline CC_3225 & $\begin{array}{l}\text { Caixa sensora Histidina } \\
\text { quinase / regulador de } \\
\text { resposta }\end{array}$ & TTTGTTCGCCAGATTTTTT & 12.9 & +8 & $4.8 \pm 1.9$ \\
\hline CC_0382 & $\begin{array}{l}\operatorname{tag} \text { / DNA-metiladenina } \\
\text { glicosilase I }\end{array}$ & TATGTTCCTGAAAAGTTCT & 18.5 & -44 & $3.4 \pm 1.2$ \\
\hline CC_2590 & $\begin{array}{l}\text { uvrA / exonuclease } A B C \text {, } \\
\text { subunidade } A\end{array}$ & $\begin{array}{l}\text { TTTGTTCGCATCTTGTTCT } \\
\text { CTTGTTCTCGCGACGTTCG }\end{array}$ & 17.7 & -87 & $3.5 \pm 1.0$ \\
\hline
\end{tabular}


Tabela 5 - Genes identificados pela análise in silico como sendo parte do regulon SOS em $C$. crescentus e comparação da expressão in vivo destes genes na cepa NA1000 e lexA primeira avaliação.

(Conclusão)

\begin{tabular}{|c|c|c|c|c|c|}
\hline ORF & $\begin{array}{l}\text { Nome do gene / } \\
\text { anotação em C. } \\
\text { crecentus CB15 }\end{array}$ & Caixa SOS ou descrição & $\begin{array}{l}\text { Pontuação } \\
\text { da caixa } \\
\text { SOS }\end{array}$ & $\begin{array}{l}\text { Posição } \\
\text { da caixa } \\
\text { sos }^{a}\end{array}$ & $\begin{array}{c}\text { Expressão } \\
\text { relativa } \\
\text { (lexA / } \\
\text { NA1000) }^{b}\end{array}$ \\
\hline CC_1532 & $\begin{array}{ll}\text { Proteína } & \text { hipotética } \\
\text { conservada }\end{array}$ & $\begin{array}{ll}a & \text { ATTGTTCTTGATATGTTCC } \\
& \text { TATGTTCCAACTTCGTTTG }\end{array}$ & $\begin{array}{l}20.2 \\
11.3\end{array}$ & $\begin{array}{l}+32 \\
+21\end{array}$ & $3.1 \pm 0.7$ \\
\hline CC_3515 & $\begin{array}{l}\text { Proteína hipotética } \\
\text { conservada }\end{array}$ & a AGAGTTCGCATTATGTTCT & 15.7 & -79 & $3.1 \pm 0.6$ \\
\hline CC_1468 & $\begin{array}{l}\text { ssb / Proteína ligadora } \\
\text { a DNA fita simples }\end{array}$ & a TTTGTTCTCATAACGTTCT & 18.6 & -93 & $2.1 \pm 1.0$ \\
\hline CC_3130 & $\begin{array}{l}\text { Proteína da família } \\
\text { da glutamina } \\
\text { sintetase }\end{array}$ & $\begin{array}{l}\text { TTTGTTCTCGAAAGGTTTC } \\
\text { GTTTTTCCGGATTTGTTCT }\end{array}$ & $\begin{array}{l}14.4 \\
11.7\end{array}$ & $\begin{array}{l}-52 \\
-41\end{array}$ & $2.1 \pm 0.9$ \\
\hline CC_2878.1 & $\begin{array}{l}\text { Proteína hipotética } \\
\text { conservada }\end{array}$ & CATGTTCTGACTATGTTCC & 14.3 & -55 & $1.4 \pm 0.7$ \\
\hline CC_2589 & Proteína hipotética & $\begin{array}{l}\text { TTTGTTCGCATCTTGTTCT } \\
\text { CTTGTTCTCGCGACGTTCG }\end{array}$ & $\begin{array}{l}17.7 \\
10.6\end{array}$ & $\begin{array}{l}-154 \\
+27\end{array}$ & $0.9 \pm 0.3$ \\
\hline CC_1928 & $\begin{array}{l}\text { Hidrolase de } \\
\text { nucleosídeos que } \\
\text { prefere inosinas e } \\
\text { uridinas }\end{array}$ & $\begin{array}{l}\text { CATATTCCGGTTTTGTTCT } \\
\text { AGATTTCTTGTTTTGTTCC } \\
\text { TCTGTTCACAAGATGTTCC }\end{array}$ & $\begin{array}{l}\text { C6.4 } \\
11.4 \\
11.1\end{array}$ & $\begin{array}{l}-126 \\
-110 \\
-126\end{array}$ & $0.8 \pm 0.2$ \\
\hline CC_1086 & $\begin{array}{l}\text { Proteína caixa } \\
\text { sensora }\end{array}$ & CATGTTCGCAAGATGTTCC & 15.5 & -114 & $0.8 \pm 0.2$ \\
\hline CC_2314 & $\begin{array}{l}\text { Carbamoil-fosfato } \\
\text { sintase } \\
\text { Transferase de } \\
\text { carboxilas }\end{array}$ & CATGTTCCACTTTTGTTCT & 17.9 & -103 & $0.6 \pm 0.5$ \\
\hline CC_1665 & $\begin{array}{l}\text { dnaB / helicase de } \\
\text { DNA replicativa }\end{array}$ & GATGTTCTGTGTATGTTTT & 14.5 & -73 & $0.3 \pm 0.1$ \\
\hline CC_2433 & $\begin{array}{l}\text { Proteína hipotética } \\
\text { conservada }\end{array}$ & АTTATTTTCATTATGTTTT & 16.5 & -105 & $0.1 \pm 0.0$ \\
\hline
\end{tabular}

a: Posição relativa ao primeiro códon ATG da JAL

b: Determinada por RT-PCR quantitativo, em relação ao gene rho 
Dos 44 genes testados inicialmente, 35 foram considerados como pertencentes ao regulon SOS de $C$. crescentus por apresentarem expressão relativa superior a 2 . Alguns destes sabidamente são regulados por LexA em outras bactérias (Erill et al., 2004), como recA (CC_1087), lexA (CC_1902), uvrA (CC_2590), ssb (CC_1468), recN (CC_1983) e o operon ruvCAB (cujos genes são expressos em níveis semelhantes, e devem provavelmente constituir realmente um operon). Encontramos também alguns genes relacionados a metabolismo de DNA, como foi o caso de CC_2272 (endonuclease III), CC_0382 (tag, DNA metiladenina glicosilase), CC_2333 (uracila DNA glicosilase), CC_3518 (que possui um domínio semelhante ao N-terminal de UvrC) e CC_1330 e CC_2332 (que apresentam domínio de fotoliase) (Martins-Pinheiro et al., 2007).

Em relação aos prováveis operons, a análise dos níveis de expressão corrobora todos com a exceção daquele que deveria ser composto pelos genes dnaE (CC_1926) e CC_1927.

No restante, os demais genes induzidos codificam proteínas hipotéticas e hipotéticas conservadas, e representam campo ainda aberto para estudos.

Um fato que nos chamou a atenção foi o da aparente repressão de dois genes na ausência de LexA: dnaB (CC_1665) e CC_2433. Apesar de apresentarem caixas SOS de alta pontuação, eles mostraram expressão reduzida na cepa lexA; isso pode indicar uma regulação positiva indireta ou direta de LexA, o que não é algo comumente observado nos regulons SOS de outras bactérias, como será discutido adiante.

Estas análises foram publicadas recentemente (Rocha et al., 2008), e o artigo é apresentado no final desta tese como documento anexo. Após sua publicação, ainda nos restava uma grande lista de JALS possivelmente reguladas por LeXA, mas com caixas SOS de menor pontuação. A fim de caracterizar de uma forma mais completa o regulon sOS de $C$. crescentus, selecionamos 34 caixas com pontuações entre 12.27 e 8.72 e posicionadas de forma a permitir repressão transcricional por LexA para a validação por ensaios de RT-PCR quantitativo. Os resultados se encontram na tabela 6 abaixo. 
Tabela 6 - Genes adicionais identificados pela análise in silico como sendo parte do regulon SOS em $C$. crescentus e comparação da expressão in vivo destes genes nas cepas NA1000 e lexA.

(Continua)

\begin{tabular}{|c|c|c|c|c|c|}
\hline ORF & $\begin{array}{l}\text { Nome do gene / } \\
\text { anotação em C. } \\
\text { crecentus CB15 }\end{array}$ & Caixa SOS ou descrição & $\begin{array}{l}\text { Pontuação da } \\
\text { caixa SOS }\end{array}$ & $\begin{array}{l}\text { Posição } \\
\text { da } \\
\text { caixa } \\
\text { sos }^{a}\end{array}$ & $\begin{array}{c}\text { Expressão } \\
\text { relativa } \\
\text { (lexA / }^{\text {NA1000) }}{ }^{b}\end{array}$ \\
\hline CC_3109 & $\begin{array}{ll}\text { Proteína } & \text { hipotética } \\
\text { conservada } & \end{array}$ & CGTGTTCCCCTCTTGTTCG & 11.48 & -15 & $11.4 \pm 3.9$ \\
\hline CC_2469 & Proteína hipotética & TTTGTTCTTGTTTCGTCCA & 11.04 & -20 & $6.1 \pm 2.1$ \\
\hline CC_3514 & Proteína hipotética & TTTGTTCCCGGTCCGTTCG & 10.07 & -96 & $5.2 \pm 1.7$ \\
\hline CC_0271 & $\begin{array}{l}\text { Proteína com domínio } \\
\text { RmuC }\end{array}$ & & & & $4.3 \pm 1.7$ \\
\hline CC_0781 & Proteína hipotética & TTTGTTCCCCTAGAGTCCT & 10.28 & -91 & $4.2 \pm 2.9$ \\
\hline CC_0782 & 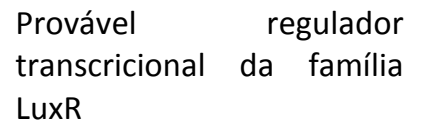 & AGCGTTCGCATAAGGTTCT & 11.27 & +34 & $4.0 \pm 1.6$ \\
\hline CC_2025 & Proteína hipotética & AATATTGACTTTATATTTTT & 10.23 & -42 & $3.8 \pm 1.3$ \\
\hline CC_1528 & uvrD / DNA helicase II & TTTGTGCTACATATGTTCC & 11.87 & -10 & $3.0 \pm 0.3$ \\
\hline CC_1836 & $\begin{array}{l}\text { Proteína } \\
\text { conservada }\end{array}$ & AATATTTGAGTCATGTTCC & 12.27 & -51 & $2.7 \pm 0.8$ \\
\hline CC_2111 & $\begin{array}{l}\text { Proteína hipotética } \\
\text { conservada }\end{array}$ & AACGTTCTCTGGTTCTTCT & 8.96 & +27 & $2.7 \pm 0.5$ \\
\hline CC_2498 & Proteína hipotética & AATTTTCGTGATTTTTTCG & 11.66 & -31 & $2.5 \pm 1.0$ \\
\hline CC_0550 & Proteína hipotética & ATTATTCCAGACACATTCT & 9.01 & -76 & $1.6 \pm 0.6$ \\
\hline CC_0539 & $\begin{array}{l}\text { Receptor dependente de } \\
\text { TonB }\end{array}$ & & & & $1.5 \pm 0.4$ \\
\hline CC_0510 & $p h b A$, acetiltransferase & ATAGCTCCCGTGACGTTCT & 8.72 & -13 & $1.5 \pm 0.2$ \\
\hline CC_3380 & $\begin{array}{l}\text { kduD } \quad / \quad \text { 2-desoxi-D- } \\
\text { gliconato 3-desidrogenase }\end{array}$ & ATTGTTCTTGAAACGCTTG & 10.91 & -25 & $1.4 \pm 0.4$ \\
\hline CC_3164 & $\begin{array}{l}\text { Regulador transcricional, } \\
\text { família } \mathrm{Cro} / \mathrm{Cl}\end{array}$ & AACGGTCGTGTCATTTTCC & 8.91 & +2 & $1.3 \pm 0.5$ \\
\hline CC_0085 & pgm, Fosfoglicomutase & ATAGTTCGTGAAATTGTCT & 9.84 & -68 & $1.3 \pm 0.3$ \\
\hline
\end{tabular}


Tabela 6 - Genes adicionais identificados pela análise in silico como sendo parte do regulon SOS em $C$. crescentus e comparação da expressão in vivo destes genes nas cepas NA1000 e lexA.

(Conclusão)

\begin{tabular}{|c|c|c|c|c|c|}
\hline ORF & $\begin{array}{l}\text { Nome do gene / } \\
\text { anotação em C. } \\
\text { crecentus CB15 }\end{array}$ & Caixa SOS ou descrição & $\begin{array}{l}\text { Pontuação da } \\
\text { caixa SOS }\end{array}$ & $\begin{array}{l}\text { Posição } \\
\text { da } \\
\text { caixa } \\
\operatorname{sos}^{a}\end{array}$ & $\begin{array}{c}\text { Expressão } \\
\text { relativa } \\
\text { (lexA / }^{\text {NA1000) }}{ }^{b}\end{array}$ \\
\hline CC_0420 & Proteína hipotética & AATAGTCCAGAAATTTTCG & 9.19 & +44 & $1.2 \pm 0.4$ \\
\hline CC_2017 & Proteína hipotética & TTTCGTGCTTTTTATGTTCT & 10.6 & +39 & $1.2 \pm 0.3$ \\
\hline CC_0041 & Proteína hipotética & AATGATCCCGTTTACTTCC & 9.2 & +29 & $1.1 \pm 0.2$ \\
\hline CC_3370 & $\begin{array}{ll}\text { Proteína } & \text { hipotética } \\
\text { conservada } & \end{array}$ & CATGTTCCTGTTCCTTTTC & 10.56 & -7 & $1.1 \pm 0.2$ \\
\hline CC_0686 & groES, Chaperonina & CTTGGTCTTGGTTTCTTCT & 9.82 & +56 & $1.0 \pm 0.5$ \\
\hline CC_0392 & $\begin{array}{l}\text { Provável proteína de } \\
\text { membrana }\end{array}$ & GATGTTCCCCCCTTTTTTTT & 9.12 & -13 & $1.0 \pm 0.2$ \\
\hline CC_1543 & $\begin{array}{l}\text { mreB / proteína } \\
\text { determinante da forma de } \\
\text { rod }\end{array}$ & АATGTTCTCTTCCCTTTTTC & 9.16 & +8 & $0.9 \pm 0.2$ \\
\hline CC_0575 & Provável beta-lactamase & AATCTTCCAGCCATGTTTC & 9.89 & -13 & $0.9 \pm 0.1$ \\
\hline CC_3284 & $\begin{array}{l}\text { Fosforibosilaminoimidazole } \\
\text { carboxilase, subunidade } \\
\text { catalítica }\end{array}$ & AACGCTCTTGTGTCGTTTT & 9.43 & -85 & $0.8 \pm 0.3$ \\
\hline CC_3620 & tktA / transcetolase I & TTCCGTCTTTATATGTTTT & 10.56 & -16 & $0.8 \pm 0.2$ \\
\hline CC_1272 & $\begin{array}{l}\text { rpoA / RNA polimerase } \\
\text { dependente de DNA, } \\
\text { subunidade alfa }\end{array}$ & AACGGTCGTGTCATTTTCC & 9.88 & -35 & $0.7 \pm 0.1$ \\
\hline CC_1729 & $\begin{array}{l}\text { Complexo piruvato } \\
\text { desidrogenase, } \\
\text { componente } \\
\text { E2,dihidrolipoamida } \\
\text { acetiltransferase }\end{array}$ & TTTGTTCCCCTAGAGTCCT & 9.46 & +20 & $0.7 \pm 0.1$ \\
\hline CC_0975 & Proteína hipotética & AATGTGCCAGTTGCGTTCT & 10.61 & +88 & $0.6 \pm 0.2$ \\
\hline CC_2630 & $\begin{array}{l}\text { hfaD / autentica alteração } \\
\text { do código de leitura }\end{array}$ & TTCGTTCCCAGATTGTTGT & 9.56 & -72 & $0.5 \pm 0.2$ \\
\hline CC_0692 & Proteína hipotética & TTTGTTGAGAAATTGTTGT & 9.26 & -31 & $0.5 \pm 0.1$ \\
\hline
\end{tabular}

a: Posição relativa ao primeiro códon ATG da JAL

b: Determinada por RT-PCR quantitativo, em relação ao gene rho 
Dos 34 novos genes testados, 11 apresentaram indução relativa superior a 2 e também foram considerados, portanto, parte do regulon SOS em C. crescentus. A grande maioria destes genes codifica para proteínas hipotéticas ou hipotéticas conservadas, com a exceção de uvrD (CC_1528), que codifica proteína envolvida em reparo de DNA, e de um possível regulador transcricional (CC_0782).

\subsubsection{Funcionalidade in vivo do operador SOS}

Para validar nosso modelo de consenso de ligação de LexA, determinamos a funcionalidade do mesmo in vivo através da mutagênese sítio dirigida na região promotora do gene imuA, que apresenta um operador com elevada pontuação e níveis altos de indução na cepa lexA.

Duas substituições de bases foram inseridas no sítio potencial de ligação a LexA, criando um mutante operador-constitutivo (Oc) para o promotor de imuA. As atividades dos promotores selvagem e constitutivo foram avaliadas através da fusão destes com o gene repórter lacZ (Figura 10).

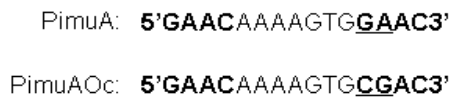

A

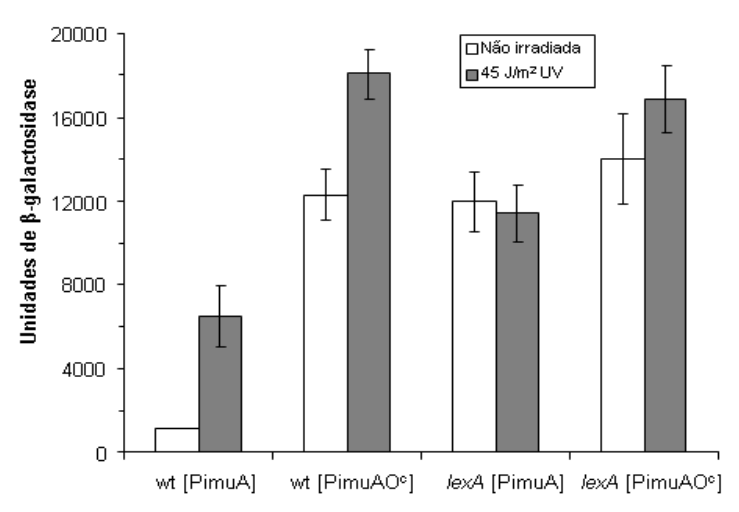

Figura 10 - Mutagënese sitio dirigida do promotor de imuA e análise da atividade dos promotores por ensaios de $\beta$-galactosidase. A: $O$ operador SOS no promotor de imuA está indicado em negrito. As bases sublinhadas foram alteradas em PimuAOc para eliminar a repetição direta. B: Média de três medições das unidades de bgalactosidase produzidas pelos plasmídeos PimuA ou PimuAOc nas cepas NA100O e lexA. A indução do SOS foi obtida pela irradiação das culturas com $45 \mathrm{~J} / \mathrm{m}^{2}$ de luz UVC. 
Como podemos observar, os níveis de expressão do promotor $\operatorname{PimuAO}^{c}$ são mais elevados do que os observados para o promotor selvagem, mostrando que o operador em questão realmente contribui para a repressão de imuA em condições fisiológicas. Também observamos que os níveis de expressão de $\beta$-galactosidase obtidos com o promotor PimuAO ${ }^{c}$ na ausência de irradiação são mais elevados do que os observados no promotor selvagem após $45 \mathrm{~J} / \mathrm{m}^{2}$ de luz UVC. Ainda assim, é possível também notar alguma indução no promotor mutado após a irradiação. Na cepa lexA, os dois promotores apresentam níveis semelhantes de indução, que não é alterada pela irradiação. Os dados de indução por UV da expressão de lacZ indicam que algum nível residual de ligação de LexA a PimuAOc ainda deve existir.

Determinamos também a posição do operador SOS em relação aos sítios de ligação da RNA polimerase nos promotores dos genes imuA e CC_2272. Para tanto, determinamos o início de transcrição destes genes através da técnica de 5’RACE (Figura 11).

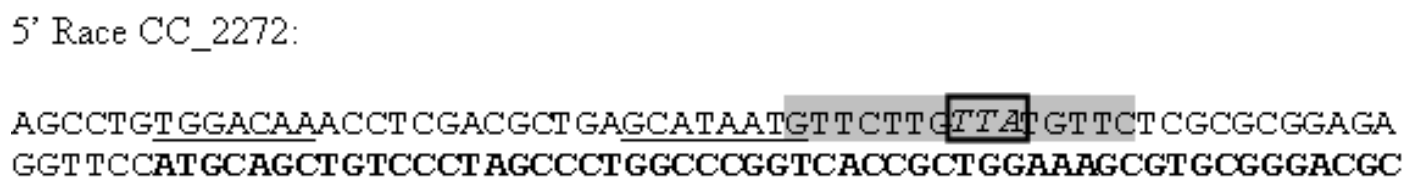

5' Race imuA:

CAAGCCT TGACT CT CCAGT CCGGGAAGATCAGAACAAAAGT GAACATGGAGT TGGGA.A TGGCCGGATCGCGCGAGGCGCGTCTTGCGGCCCTGAGAGGCCGGATCGCCGCGATGGAA GCGGGGACTOGGACTOCGACTOCGGTGCTGTCGTTCGGAGAGCCGTCGATCGACGGGTG

Consenso sigma 70: TTGaCgS $\mathrm{N}_{(10-14)}$ GCtANAJC $\mathrm{N}_{(5-7)}+1$

Figura 11 - Determinação do início de transcrição dos genes imuA e CC_2272. As seqüências codificadoras estão em negrito. $O$ início de transcrição é mostrado dentro dos quadrados pretos e em itálico. O operador SOS aparece em cinza e as seqüências -10 e -35 estão sublinhadas. $O$ consenso do promotor para o fator sigma vegetativa (Malakooti et al., 1995) é mostrado abaixo. 
O início de transcrição de imuA está a 71 nucleotídeos a 5' do códon de início anotado, enquanto para CC_2272 isso ocorre entre os nucleotídeos 23 e 25 a 5' do ATG (não foi possível a determinação exata do início pois o oligonucleotídeo utilizado para o experimento de 5'RACE contém uma seqüência de Ts, e o produto do 5'RACE começa com $\mathrm{T}_{(13-20)}$ ATGTTCTCG).

Dessa forma conseguimos demarcar as regiões consenso -10 e -35 para o fator sigma vegetativo de $C$. crescentus (Malakooti et al., 1995). Esses dados confirmam que, de fato, o operador SOS se sobrepõe o início de transcrição e a região -10 em ambos os promotores, o que deve atuar como um forte bloqueio ao acesso da RNA polimerase quando da presença de LexA.

\subsection{Procura pelo gene responsável pelo bloqueio de divisão celular no mutante lexA}

Em E. coli não é possível obter mutantes nulos para o gene lexA, devido à ação letal de sulA. O gene sulA, que é parte do regulon SOS neste organismo, é um inibidor da divisão celular, sendo capaz de se associar a FtsZ e inibir sua polimerização; isso leva a filamentação e morte das células. SulA, no entanto, está restrita a organismos filogeneticamente próximos a E. coli (Erill et al., 2003) e não existem ortólogos no genoma de $C$. crescentus. Este fato nos levou a questionar qual seria o gene responsável pela indução da filamentação na ausência de lexA.

Direcionamos nossa busca para os genes identificados até então como parte do regulon SOS. Em um momento inicial, poucos genes haviam sido identificados e testados; nossa primeira aposta foi o conjunto de genes de função até então desconhecida composto pelo possível operon CC_3038, CC_3037 e CC_3036. Estes genes nos chamaram atenção por terem níveis altos de indução na cepa lexA e por serem vizinhos a ctrA (CC_3035), um dos reguladores mestres do desenvolvimento em C. crescentus (revisto por Curtis e Brun, 2010). Para descobrir se eles possuíam alguma relação com o fenótipo em questão, construímos primeiramente uma cepa deficiente para estes três genes, denominada RM20; a PCR diagnóstico confirmando a obtenção do mutante se encontra na figura 12. 
Conjugamos então a cepa RM20 com uma E. coli S17-1 contendo o plasmídeo plexAdel. Após as seleções adequadas, obtivemos a cepa RM30, que possuía deleções nos genes lexA e no provável operon CC_3038-CC_3037-CC_3036 (confirmação por PCR não mostrada).

A análise de RM20 sob microscopia não revelou nenhuma alteração morfológica (Figura 13); as curvas de crescimento, viabilidade e sobrevivência a irradiação com luz UVC também não mostraram alterações em relação à cepa selvagem, como podemos observar nas figuras 14 e 15 .

A cepa RM30, por sua vez, possui o mesmo fenótipo do mutante lexA, nos levando a conclusão que o operon CC_3038-CC_3037-CC_3036 não está envolvido na filamentação observada na ausência de LexA (Figura 13). Seu crescimento e sobrevivência frente à luz UVC também se mostraram semelhantes ao de lexA, como podemos observar nas figuras 14 e 15 .

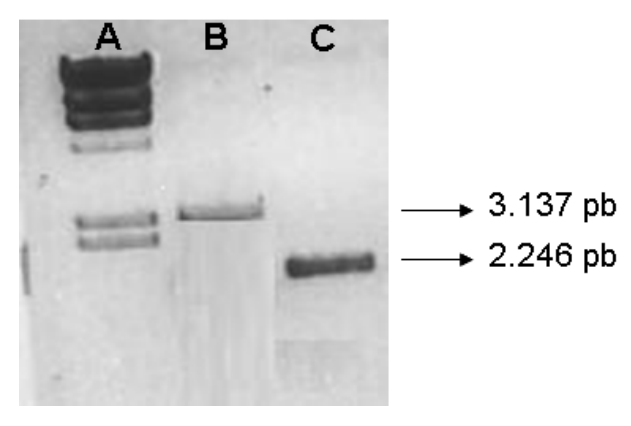

Figura 12 - PCR diagnóstico confirmando a deleção do operon CC_3038-CC_3037-CC_3036. Coluna A: marcador $\lambda$ HindIII, coluna B: PCR da cepa contendo deleção no operon $e$ inserção do cassete de resistência a espectinomicina, coluna C: PCR a partir da cepa NA1000. Os tamanhos dos fragmentos se encontram indicados ao lado. 

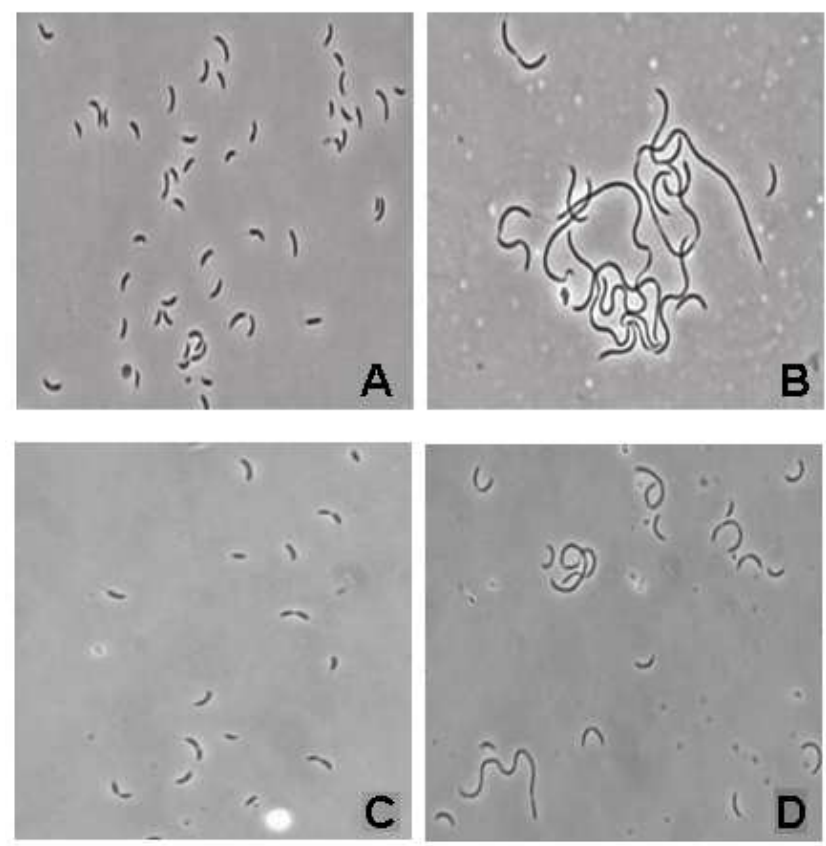

Figura 13 - Análise microscópica das cepas NA1000, lexA, RM20 e RM30 de C. crescentus. A: NA1000, B: lexA, C: RM20 (deficiente em CC_3038-CC_3037-CC_3036) e D: RM30 (deficiente em CC_3038-CC_3037-CC_3036 e em lexA). Foi utilizada objetiva de $100 \mathrm{x}$ de aumento.
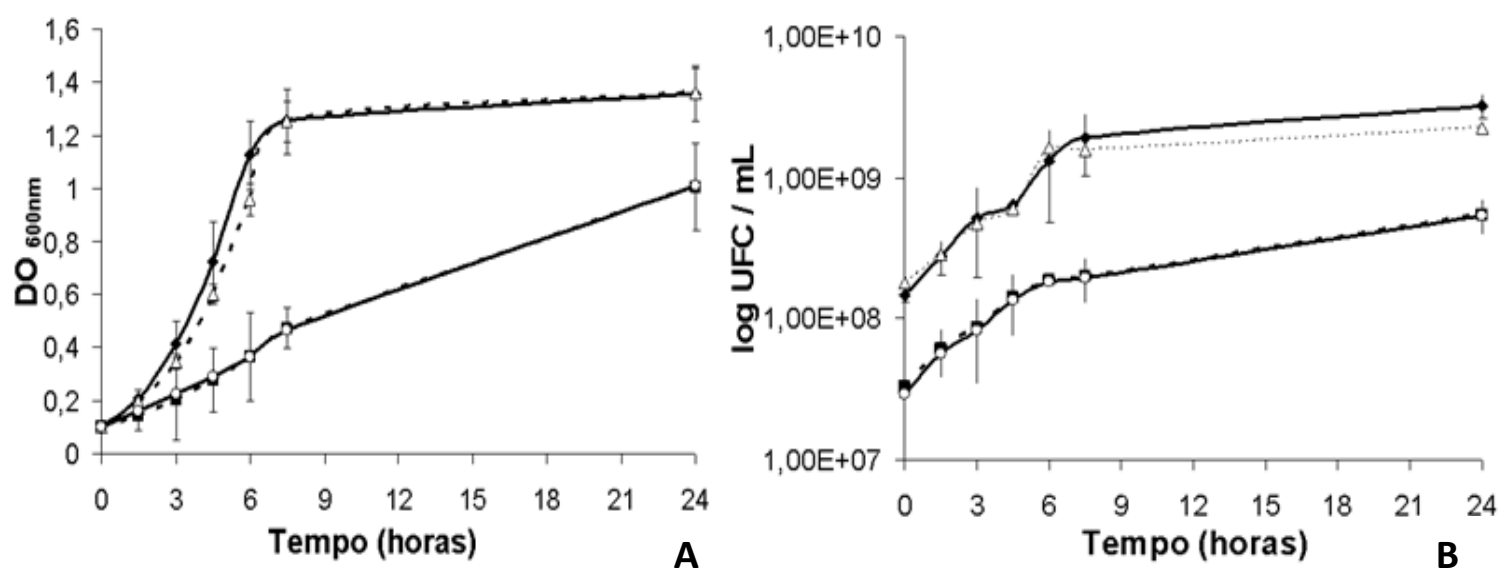

Figura 14 - Curvas de crescimento das cepas NA1000, lexA, RM20 e RM30. Curvas determinadas através da densidade ótica da cultura bacteriana (A) e contagem do número de unidades formadoras de colônias (B). Linha cheia com losango cheio: cepa selvagem NA1000; linha tracejada com quadrado cheio: lexA; linha tracejada com triângulo vazio: RM20; linha cheia com círculo vazio: RM30. As figuras representam médias e desvios padrões de três experimentos independentes. 


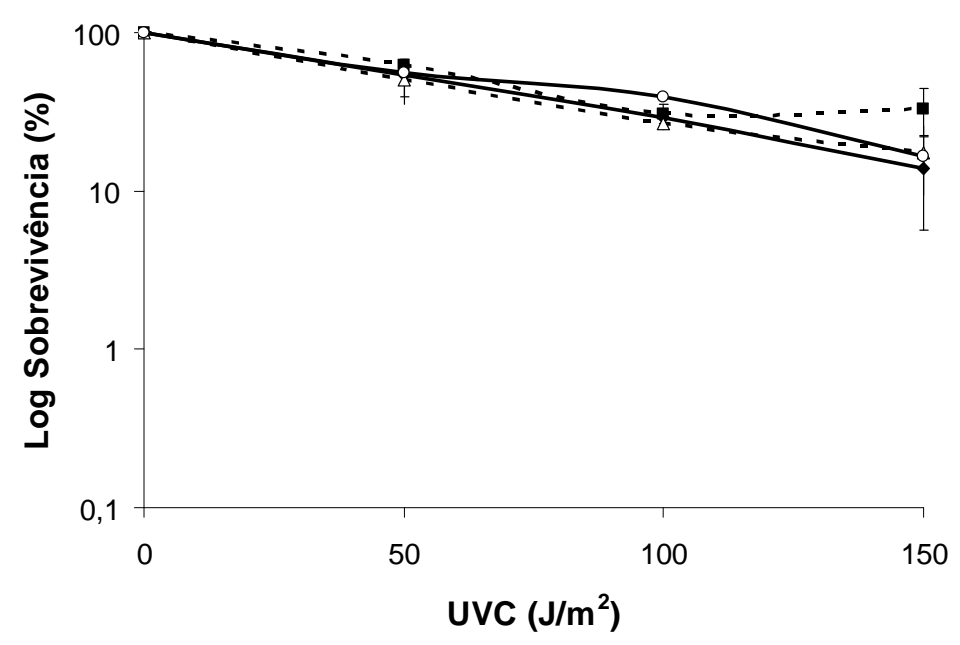

Figura 15 - Sobrevivência das cepas NA1000, lexA, RM20 e RM30 frente à irradiação com luz UVC. A figura representa médias e desvios padrões de pelo menos três experimentos diferentes. As doses de UVC se encontram indicadas na figura. Linha cheia com losango cheio: cepa selvagem NA1000; linha tracejada com quadrado cheio: lexA; linha tracejada com triângulo vazio: RM20; linha cheia com círculo vazio: RM30.

Em Pandey e Gerdes (2005), foi observado que CC_3038 e CC_3037 faziam parte do sistema toxina-antitoxina higBA, enquanto CC_3036 é um provável regulador transcricional, confirmando, portanto que, de fato, não possuem relação com o bloqueio da divisão celular. No genoma de NA1000 recentemente publicado (Marks et al., 2010), estes genes já se encontram anotados de forma correta.

Com a progressão da caracterização do regulon SOS, obtivemos novos genes candidatos a serem os mediadores da filamentação em lexA. A próxima JAL testada foi CC_0627, que era uma das mais induzidas na ausência de LexA, assim como sulA em E. coli (Courcelle et al., 2001). Foi construída, então, uma cepa deficiente para a JAL CC_0627, que codifica uma proteína hipotética de 111 aminoácidos (Figura 16). 


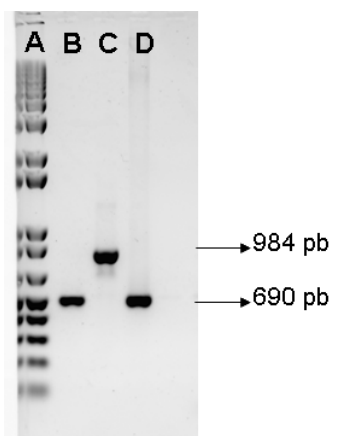

Figura 16 - PCR diagnóstico confirmando a deleção do gene CC_0627. Coluna A: marcador $1 \mathrm{~Kb}$ Plus (Invitrogen, EUA), coluna B: PCR da cepa contendo deleção no gene, coluna C: PCR a partir da cepa NA1000, coluna D: PCR feito a partir do plasmídeo pNPTS138 contendo a cópia deletada de CC_0627. Os tamanhos dos fragmentos se encontram indicados ao lado.

Esta se apresentou similar a selvagem na análise microscópica (Figura 17), mas com maior sensibilidade à luz UVC do que NA1000 (Figura 18), revelando um possível papel importante na resposta a danos ao DNA. Até o momento não avaliamos seu perfil de crescimento e viabilidade celular.

Utilizando a mesma estratégia empregada para construir o duplo mutante descrito acima, construímos também o duplo mutante lexA e CC_0627, chamado de RM90. Analisamos quinze clones, e todos eles apresentaram morfologia semelhante a da cepa lexA (Figura 17). Provavelmente CC_0627 também não está envolvido no bloqueio da divisão celular que ocorre em lexA.
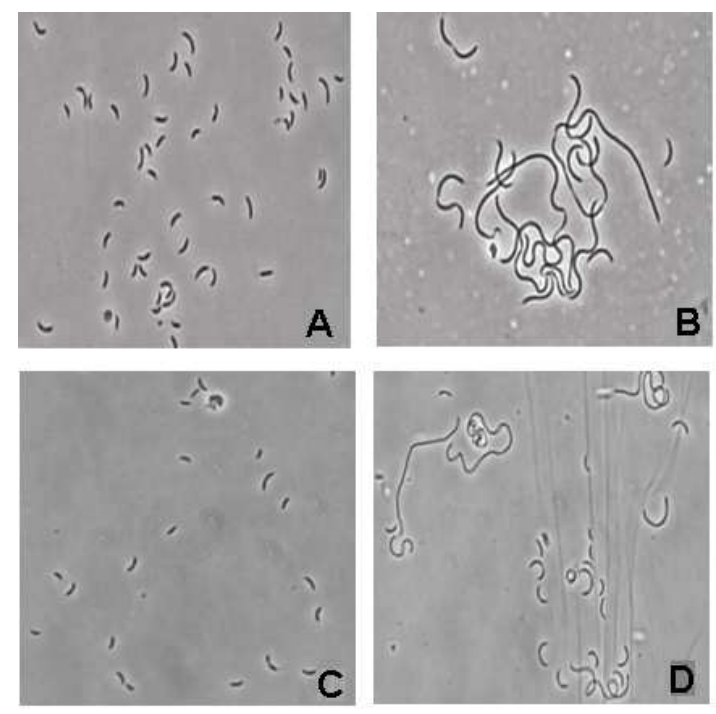

Figura 17 - Análise microscópica das cepas NA1000, lexA, CC_0627 e RM90 de C. crescentus. A: NA1000, B: lexA, C: CC_0627 e D: RM90 (deficiente em CC_0627 e lexA). Foi utilizada objetiva de $100 \times$ de aumento. 


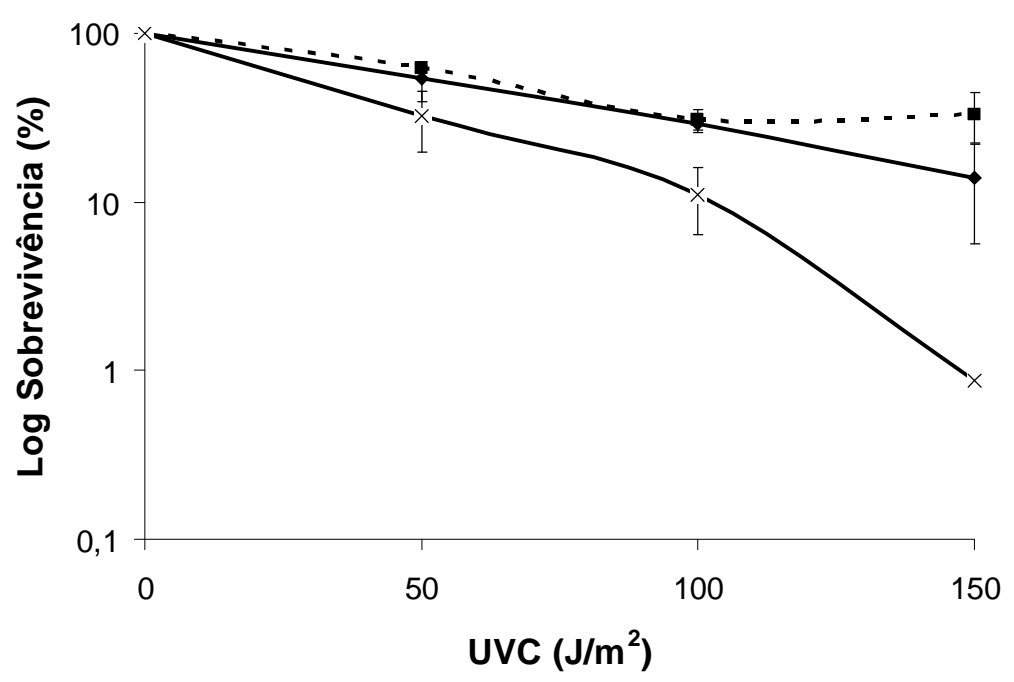

Figura 18 - Sobrevivência das cepas NA1000, lexA e CC_0627 frente à irradiação com luz UVC. A figura representa médias e desvios padrões de pelo menos três experimentos diferentes. As doses de UVC se encontram indicadas na figura. Linha cheia com losango cheio: NA1000, linha tracejada com quadrado cheio: lexA, linha cheia com x: CC_0627.

O último gene identificado como parte do regulon SOS e que foi cogitado como tendo alguma relação com a filamentação de lexA foi CC_3225. Este gene codifica uma proteína híbrida, contendo domínios de histidina quinase e regulador de resposta. Histidinas quinases são importantes proteínas envolvidas em sinalização em procariontes; elas estão relacionadas à transdução de sinais endógenos ou exógenos até a promoção da resposta adequada a eles pela célula. A proposição de que a filamentação poderia ser indiretamente mediada por lexA, através da transdução de algum sinal endógeno via uma cadeia de transferência de fosfatos nos levou a testar a influência de CC_3225. A cepa deficiente em CC_3225 havia sido descrita em Skerker et al. (2005), e foi gentilmente cedida pelo Dr. Michael T. Laub.

A cepa deficiente em CC_3225 se comporta de forma semelhante à cepa selvagem NA1000 no que se refere ao crescimento, viabilidade e sobrevivência frente à luz UVC (Figuras 19 e 20); sua observação sob microscopia ótica (Figura 21) também revelou que ela não possui alterações morfológicas perceptíveis.

Seguindo o mesmo raciocínio utilizado anteriorment, construímos também uma cepa contendo deleções em CC_3225 e lexA através da conjugação do plasmídeo plexAdel em uma E. coli S-17 com a cepa deficiente para CC_3225; este novo mutante foi denominado 
RM40. Sua análise microscópica revelou fenótipo semelhante àquele observado para lexA (Figura 21), e por isso, CC_3225 também parece não ter relação com o processo de filamentação mediado por LexA.
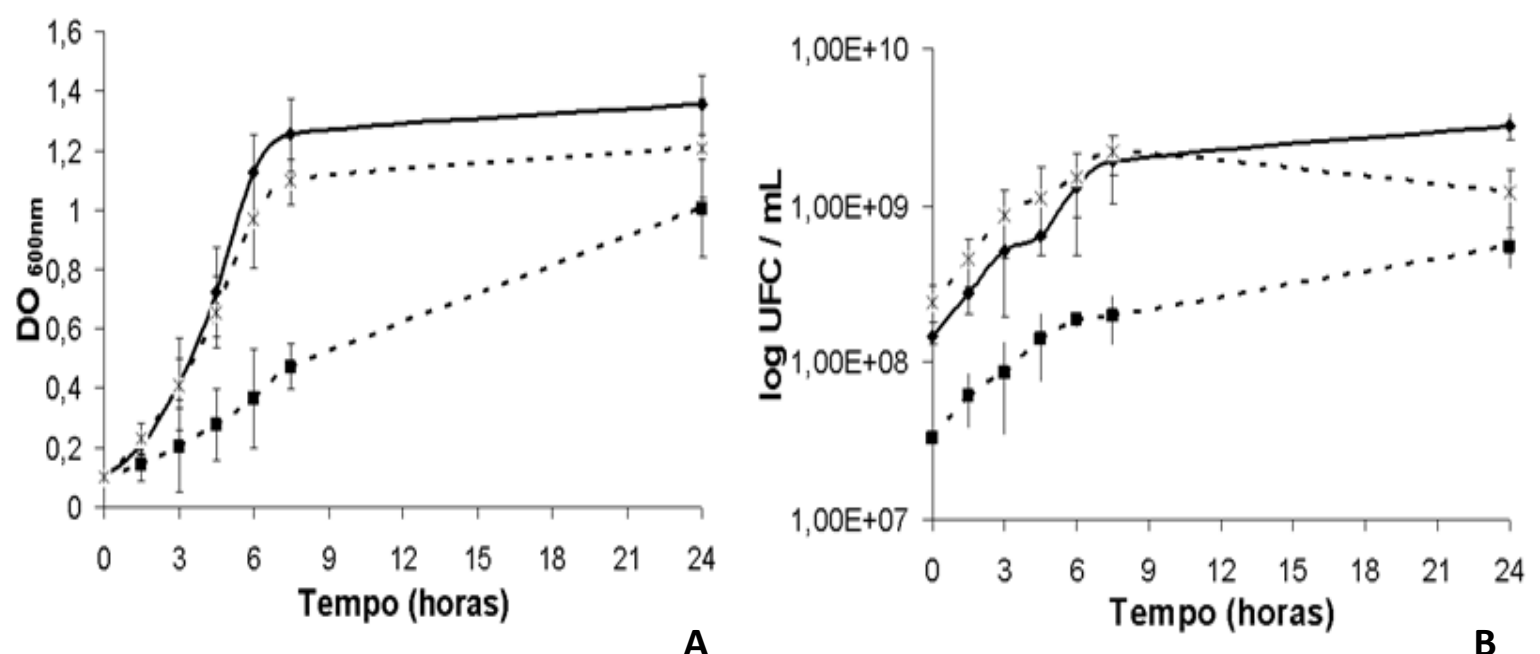

Figura 19 - Curvas de crescimento das cepas NA1000, lexA e CC_3225. Curvas determinadas através da densidade ótica da cultura bacteriana (A) e contagem do número de unidades formadoras de colônias (B.) Linha cheia com losango cheio: cepa selvagem NA1000; linha tracejada com quadrado cheio: lexA; linha tracejada com x: CC_3225. As figuras representam médias e desvios padrão de três experimentos independentes.

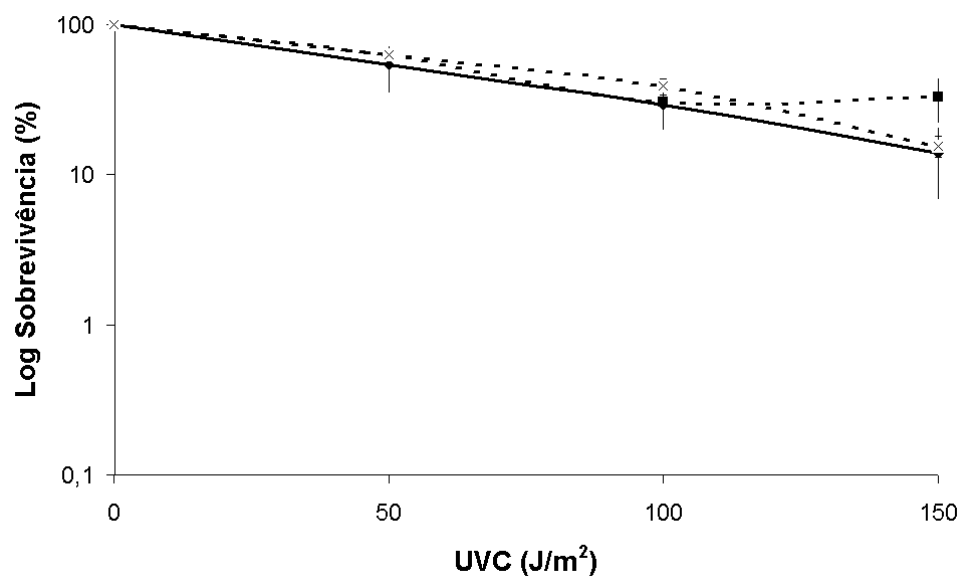

Figura 20 - Sobrevivência das cepas NA1000, lexA e CC_3225 frente à irradiação com luz UVC. A figura representa médias e desvios padrões de pelo menos três experimentos diferentes. As doses de UVC se encontram indicadas na figura. Linha cheia com losango cheio: cepa selvagem NA1000; linha tracejada com quadrado cheio: lexA; linha tracejada com $x$ : CC_3225. 

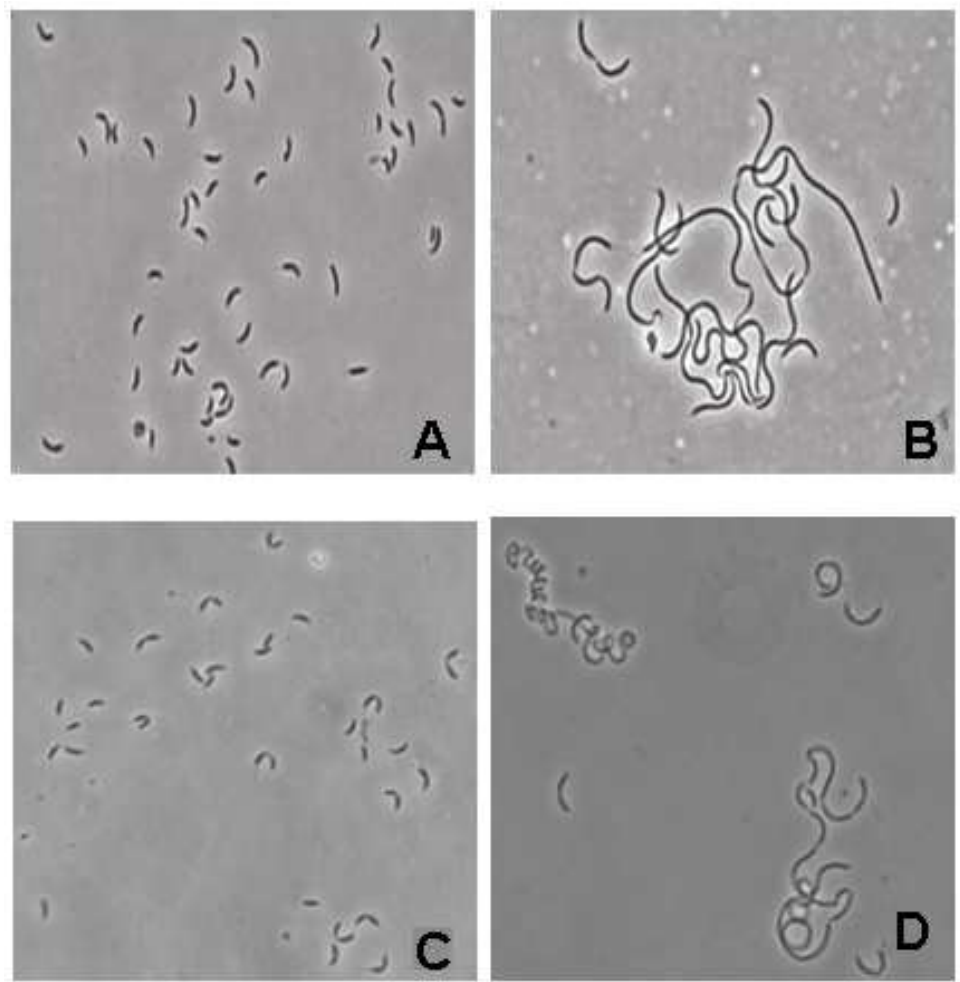

Figura 21 - Análise microscópica das cepas NA1000, lexA, CC_3225 e RM40 de C. crescentus. A: NA1000, B: lexA, C: CC_3225 e D: RM40 (deficiente em CC_3225 e lexA). Foi utilizada objetiva de $100 \times$ de aumento.

Uma vez que os genes identificados como parte do regulon sos e mais provavelmente relacionados com a filamentação de lexA já haviam sido testados, decidimos empregar uma nova estratégia para a busca do gene responsável pelo fenótipo em questão. Utilizando o transposon Mariner (Viollier et al., 2004), realizamos a mutagênese aleatória da cepa lexA na esperança de que, uma vez interrompido pelo transposon o gene responsável pela filamentação, obteríamos um clone com morfologia semelhante a da NA1000; o gene poderia ser então identificado através de seqüenciamento utilizando iniciadores contidos no transposon. A seleção dos clones foi realizada com base em ensaio de natação: dado o caráter filamentoso de lexA, é de se esperar que esta bactéria possua dificuldade de locomoção em meio semi-sólido, o que pôde ser confirmado pela figura 22 abaixo. O halo de natação obtido com a cepa selvagem NA1000 é muito superior àquele observado para lexA; e como podemos observar no exemplo da figura, nenhum dos clones testados nesta placa apresentou capacidade natatória superior a $\operatorname{de} \operatorname{lex} A$, indicando que neste caso, nenhum deles reverteu o fenótipo filamentoso. 


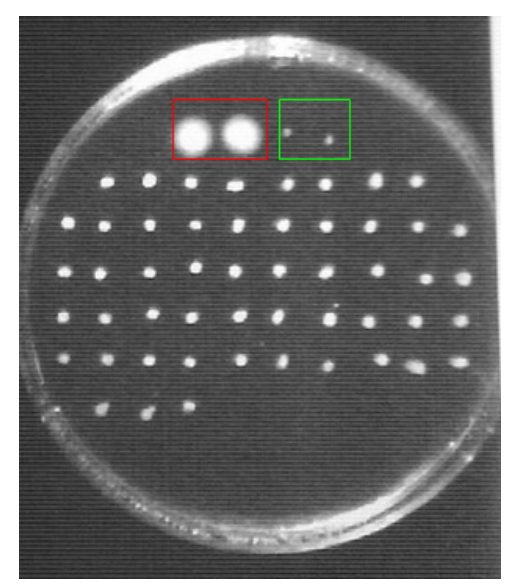

Figura 22 - Exemplo representativo do ensaio de natação realizado com $C$. crescentus para buscar um revertente do fenótipo não nadador. Quadrado vermelho: cepa selvagem NA1000, quadrado verde: lexA, demais colônias: clones de lexA que sofreram mutagênese aleatória com o transposon Mariner e mantiveram fenótipo não nadador, semelhante ao de lexA.

No total foram testados 7.266 clones, e nenhum deles apresentou melhoria significativa no potencial natatório em relação à lexA. É possível que o gene que promova o fenótipo filamentoso para lexA seja essencial (na presença da mutação lexA), e caso isso seja verdade, nós não seremos capazes de identificá-lo por esta análise. É possível também que a filamentação seja mediada por outro mecanismo, que envolva mais genes e sinalizações mais complexas. Portanto, até o momento não fomos capazes de identificar o responsável pelo bloqueio da divisão celular observado em lexA.

\subsection{Análise funcional de genes pertencentes ao regulon SOS}

Uma vez que o regulon SOS de $C$. crescentus já estava determinado, decidimos nos voltar à análise da função de alguns dos genes pertencente a ele. 


\subsubsection{CC_2272, membro da família das endonucleases III}

Nosso primeiro alvo foi a JAL CC_2272, que codifica uma proteína da família das endonucleases III. Estas enzimas, da via de reparo BER, são tipicamente DNA glicosilases/AP liases, que atuam em pirimidinas com anéis saturados, contraídos ou fragmentados, e não nos fotoprodutos CPD e 6-4 PP (Friedberg et al., 2006). Desconhecemos outro trabalho que tenha descrito um gene de BER como parte do regulon SOS e, assim, decidimos que seria interessante estudar a função deste gene através da construção de uma cepa deficiente para ele.

Em E. coli, existe um segundo mecanismo responsável pela remoção dos mesmos tipos de lesões normalmente reparados pela endonuclease III, mediado pela endonuclease VIII (Nei). Com isso, apenas o duplo mutante nestes dois genes é sensível ao tratamento com $\mathrm{H}_{2} \mathrm{O}_{2}$ e radiação ionizante (Cunningham e Weiss, 1985). C. crescentus não possui homólogos de nei em seu genoma, possuindo, no entanto, outra proteína da família das endonucleases III (CC_3731) (Martins-Pinheiro et al., 2007).

A fim de compreender com maior detalhamento a relação entre esses dois genes, construímos uma árvore filogenética contendo a seqüência destes genes e de outros similares em outros organismos (Figura 23). O que podemos observar a partir desta árvore é que CC_2272 e CC_3731 não parecem ser próximos, sendo provavelmente o fruto de uma duplicação antiga, uma vez que o primeiro aparece agrupado com a classe de DeinococcusThermus, enquanto o segundo agrupa com as proteobactérias alfa, o grupo de Caulobacter. Esta filogenia indica que CC_2272 é o provável resultado de evento de transferência gênica horizontal; alternativamente podem ter ocorrido vários eventos de perda dos homólogos a esse gene em diferentes linhagens bacterianas. 


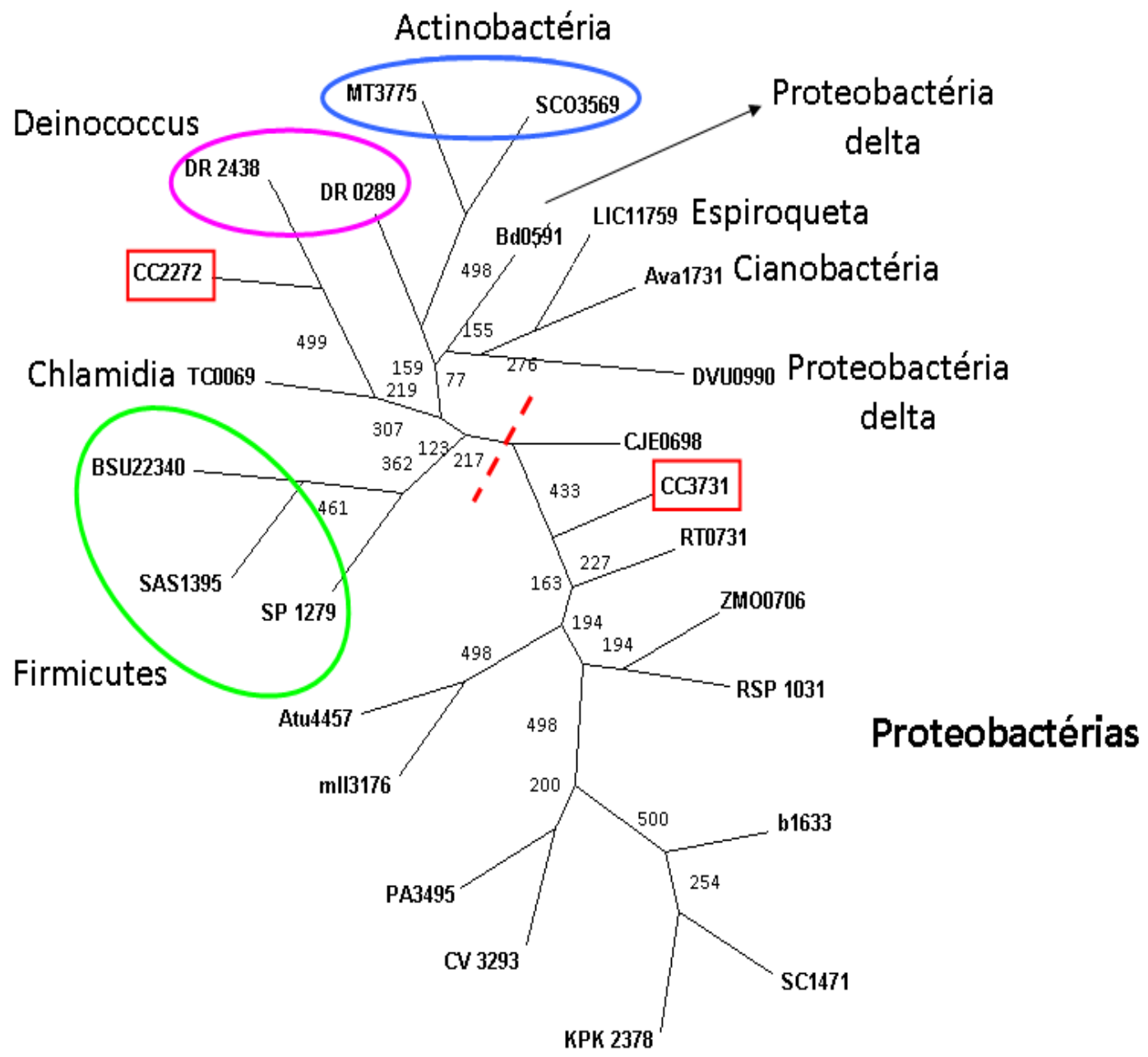

Figura 23 - Árvore filogenética de endonucleases III dos organismos selecionados. Somente genomas completamente seqüenciados foram incluídos na análise e os nomes das JALs e abreviações das espécies mostradas são as mesmas utilizadas na anotação dos genomas de cada organismo. Todas as espécies abaixo da linha tracejada vermelha pertencem ao grupo das proteobactérias. Os valores de bootstrap se encontram representados na figura. As abreviações dos nomes dos organismos são: Atu, Agrobacterim tumefaciens str. C58; Ava, Anabaena variabilis ATCC 29413; b. E. coli K12; Bd, Bdellovibrio bacteriovorus HD100; BSU, Bacillus subtilis; CC, Caulobacter crescentus CB15; CJE, Campylobacter jejuni RM1221; CV, Chromobacterium violaceum ATCC 12472; DR, Deinococcus radiodurans R1; DVU, Desulfovibrio vulgaris subsp. Vulgaris str. Hildenborough; KPK, Klebisiella pneumoniae 342; LIC, Leptospita interrogans serovar Copenhagen str. Fiocruz L1-130; mll, Mesorhizobium loti MAFF303099; MT, Mycobacterium tuberculosis CDC1551; PA, Pseudomonas aeruginosa PAO1; RSP, Rhodobacter sphaeroides 2.4.1; RT, Rickettsia typhi str. Wilmington; SAS, Staphylococcus aureus subsp. Aureus MSSA476; SC, Salmonella enterica subsp. Enterica serovar Choleresuis str. SC-B67; SCO, Streptomyces coelicolor A3 (2); SP, Streptococcus pneumoniae TIGR4; TC, Chlamydia muridarum Nigg; ZM, Zymomonas mobilis subsp. Mobilis ZM4. 
Os genes da via BER apresentam constantemente grande sobreposição de funções e vias alternativas que realizam as mesmas funções; sendo assim, era esperado que a linhagem mutante para o gene CC_2272 fosse viável. O estabelecimento desta, no entanto, não foi fácil e só foi obtida após dois experimentos. No entanto, obtivemos três clones contendo a deleção esperada em CC_2272, como podemos observar no PCR diagnóstico para a deleção de CC_2272 abaixo (Figura 24).

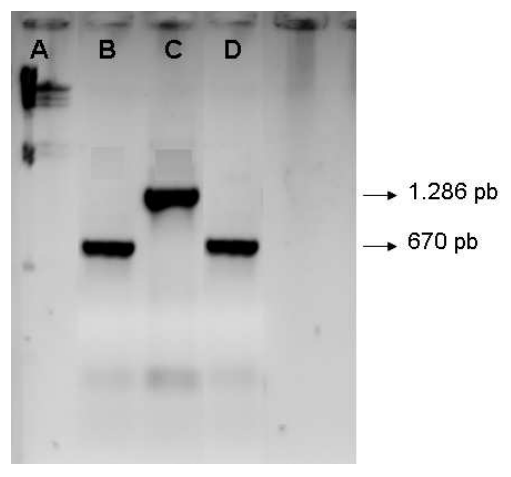

Figura 24 - PCR diagnóstico confirmando a deleção do gene CC_2272. Coluna A: marcador $1 \mathrm{~Kb}$ Plus (Invitrogen, EUA), coluna B: PCR da cepa contendo deleção no gene, coluna $\mathbf{C}$ : PCR a partir da cepa NA1000, coluna D: PCR feito a partir do plasmídeo pNPTS138 contendo a cópia deletada de CC_2272. Os tamanhos dos fragmentos se encontram indicados ao lado.

Construímos também uma cepa mutante para CC_3731 e outra contendo deleções nas duas JALs (CC_2272 e CC_3731), denominado então RM70. Para facilitar as etapas de seleção do duplo mutante, utilizamos para a construção da cepa deficiente em CC_3731 a inserção de um cassete de resistência a espectinomicina no interior da região codificante, interrompendo assim o gene em questão e resultando, provavelmente, em uma proteína não funcional. A obtenção de uma cepa deficiente em CC_3731 se mostrou também viável (Figura 25). 


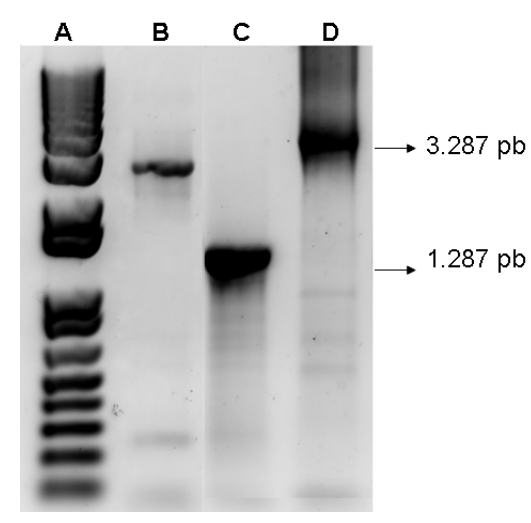

Figura 25 - PCR diagnóstico confirmando a inativação do gene CC_3731 pela inserção do cassete de resistência a espectinomicina. Coluna A: marcador $1 \mathrm{~Kb}$ Plus (Invitrogen, EUA), coluna B: PCR da cepa contendo interrupção no gene, coluna C: PCR a partir de NA1000, coluna D: PCR feito a partir do plasmídeo pNPTS138 contendo a cópia de CC_3137 com inserção do cassete de resistência. Os tamanhos dos fragmentos se encontram indicados ao lado.

As cepas deficientes em CC_2272 e CC_3731 e o duplo mutante não se mostraram diferentes da selvagem no que se refere ao aspecto microscópico após crescimento em meio rico, como podemos observar na figura 26.
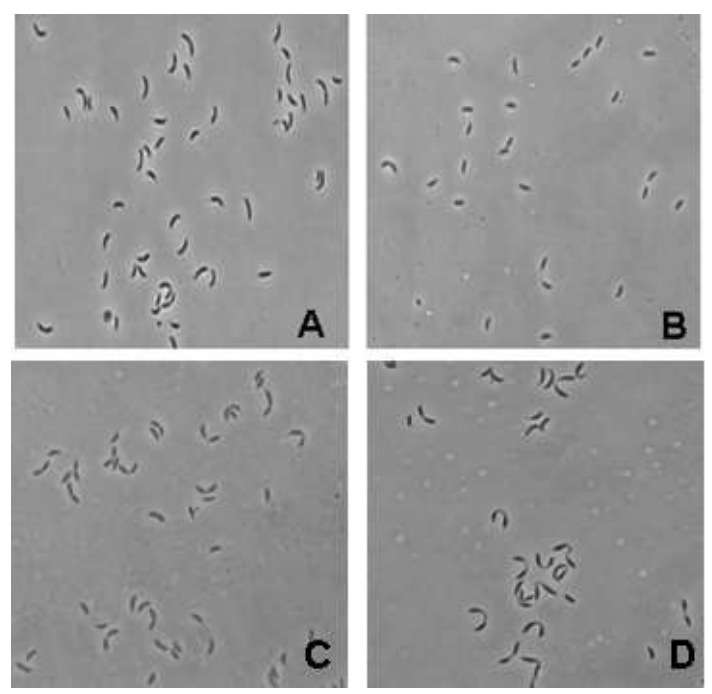

Figura 26 - Análise microscópica das cepas NA1000, CC_2272, CC_3731 e RM70 de C. crescentus. A: NA1000, B: CC_2272, C: CC_3731 e D: RM70. Foi utilizada objetiva de $100 \times$ de aumento.

Analisamos o crescimento destas cepas em meio complexo, e não foram observadas diferenças significativas em relação a selvagem NA1000 (Figura 27). Nenhuma delas 
apresentou qualquer alteração de sobrevivência frente à irradiação com luz UVC, apesar das proteínas da família da endonuclease III estarem envolvidas na remoção de lesões geradas por altas doses de UV (Figura 28).
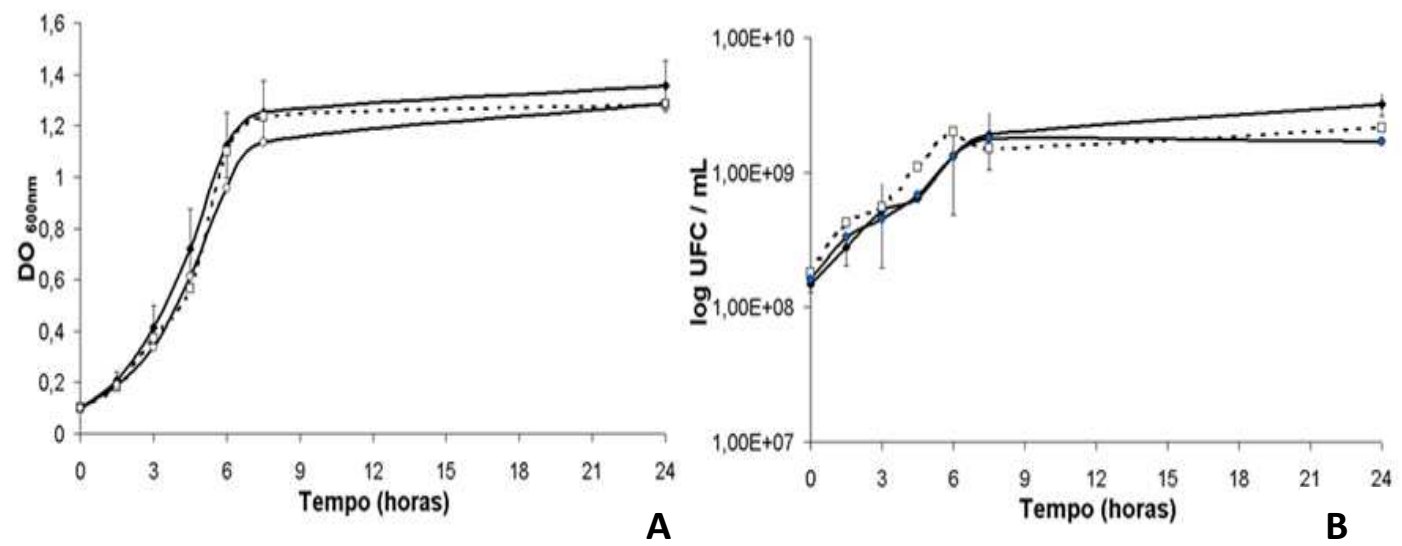

Figura 27 - Curvas de crescimento das cepas NA1000, CC_2272 e CC_3731. Curvas determinadas através da densidade ótica da cultura bacteriana (A) e contagem do número de unidades formadoras de colônias (B). Linha cheia com losango cheio: cepa selvagem NA1000; linha tracejada com quadrado vazio: CC_2272; linha cheia com círculo vazio: CC_3731. As figuras representam médias e desvios padrão de três experimentos independentes.

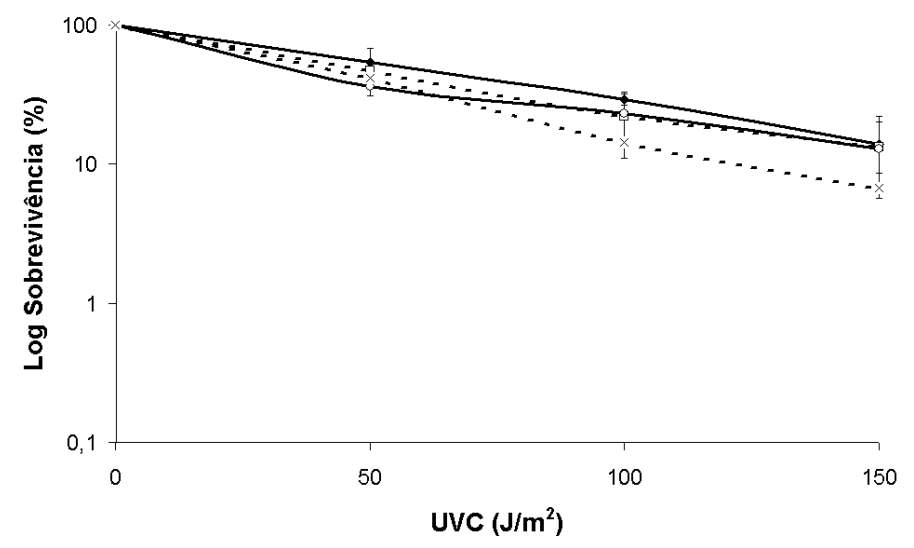

Figura 28 - Sobrevivência das cepas NA1000, CC_2272, CC3731 e RM70 frente à irradiação com luz UVC. A figura representa médias e desvios padrões de pelo menos três experimentos diferentes. As doses de UVC se encontram indicadas na figura). Linha cheia com losango cheio: cepa selvagem NA1000; linha tracejada com quadrado vazio: CC_2272; linha cheia com círculo vazio: CC_3731; linha tracejada com x: RM70.

A freqüência de mutação espontânea do mutante CC_2272 parece ser ligeiramente superior à observada para a cepa selvagem NA1000 (Tabela 7), de acordo com observações de Cunnigham e Weiss (1985). A taxa de mutação espontânea da cepa NA1000, no entanto, 
pode variar entre $1 \times 10^{-8}$ e $1 \times 10^{-9}$ (Martins-Pinheiro, 2007), um pouco superior ao observado aqui sendo, portanto, difícil considerar essas pequenas diferenças como significativas. Não parece existir alteração na freqüência para CC_3731 (Tabela 7).

Tabela 7 - Freqüência de mutação espontânea das cepas NA1000, CC_2272 e CC_3731.

\begin{tabular}{ll}
\hline Cepa & Freqüência de mutação espontânea \\
\hline NA1000 & $8,3 \times 10^{-10}\left( \pm 1,04 \times 10^{-9}\right)$ \\
CC_2272 & $7,3 \times 10^{-9}\left( \pm 1,10 \times 10^{-8}\right)$ \\
CC_3731 & $9,8 \times 10^{-10}\left( \pm 1,38 \times 10^{-9}\right)$ \\
\hline
\end{tabular}

O próximo agente genotóxico testado foi o peróxido de oxigênio $\left(\mathrm{H}_{2} \mathrm{O}_{2}\right)$, que dentro das células pode reagir com íons de $\mathrm{Fe}^{3+}$ através da reação de Fenton, gerando o radical hidroxil $\left(\mathrm{OH}^{\natural}\right)$, considerado um dos mais reativos radicais de oxigênio (Halliwell e Gutteridge, 2000). Esta espécie reativa de oxigênio pode, por sua vez, danificar bases do DNA, dando origem a uma variada gama de alterações como sítios de perda de base e quebras de fita simples (Epe et al., 1993). Um exemplo do tipo de lesão causada por $\mathrm{H}_{2} \mathrm{O}_{2} \mathrm{e}$ removida por endonuclease III, em E. coli, é timina glicol, resultado da abstração de um átomo de hidrogênio do anel pirimidínico (Halliwell e Gutteridge, 2000). Entretanto, em E. coli, cepas mutantes para o gene $n t h$, que codifica a proteína endonuclease III, não são sensíveis ao tratamento com $\mathrm{H}_{2} \mathrm{O}_{2}$, fato esse que também se mostrou verdadeiro para as cepas CC_2272, CC_3731 e RM70 de C. crescentus após tratamento por 30 minutos com 1, 5 ou $10 \mathrm{mM}$ de $\mathrm{H}_{2} \mathrm{O}_{2}$ (Figura 29). 


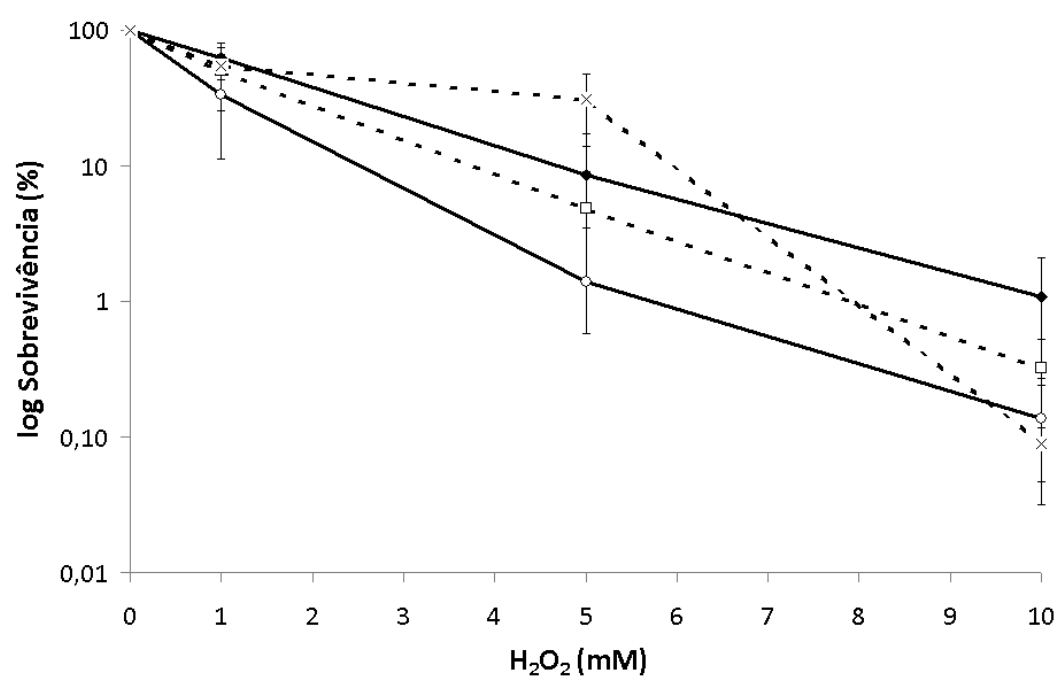

Figura 29 - Sobrevivência das cepas NA1000, CC_2272, CC3731 e RM70 frente ao tratamento com diferentes doses de $\mathrm{H}_{2} \mathrm{O}_{2}$ por $\mathbf{3 0}$ minutos. A figura representa médias e desvios padrões de pelo menos três experimentos diferentes. As doses de $\mathrm{H}_{2} \mathrm{O}_{2}$ se encontram indicadas na figura. Linha cheia com losango cheio: cepa selvagem NA1000; linha tracejada com quadrado vazio: CC_2272; linha cheia com círculo vazio: CC_3731; linha tracejada com $x:$ RM70.

Até o momento não realizamos experimentos de crescimento e viabilidade com RM70, e tão pouco testamos outros agentes oxidantes nos três mutantes.

Com os resultados obtidos até aqui, podemos concluir que provavelmente deve existir em C. crescentus algum outro gene capaz de suplantar as deficiências em CC_2272 e CC_3731 na defesa a lesões no material genético.

\subsubsection{CC_2433 e dnaB, genes possivelmente positivamente regulado por LexA}

Os genes CC_2433 (que codifica uma proteína hipotética conservada) e dnaB (CC_1665) foram determinados como membros do regulon SOS em C. crescentus, mas com uma particularidade: eles aparentemente são induzidos por LexA e não reprimidos como os outros genes do regulon. Existe poucos dados na literatura que indicam que LexA pode 
ativar transcricionalmente outro gene, como é o caso da regulação de recA em Rhodobacter sphaeroides (Tapias et al., 2002).

Aproveitando os mutantes obtidos até aqui, decidimos investigar a expressão destes genes em RM20 (deficiente em um sistema toxina-antitoxina, composto por CC_3037 e CC_3038, e em um regulador transcricional, CC_3036) e CC_3225 (que codifica uma histidina quinase híbrida), através de ensaios de RT-PCR quantitativo (Tabela 8). Utilizamos aqui novamente o gene rho (CC_3760) como controle endógeno, uma vez que sua expressão é aproximadamente a mesma em NA1000, RM20 e CC_3225 (Tabela 9).

Tabela 8 - Expressão relativa dos genes CC_2433 e dnaB (CC_1665) nas cepas CC_3225, RM20 e lexA em comparação com a cepa selvagem NA1000.

\begin{tabular}{cccc}
\hline & $\begin{array}{c}\text { Expressão relativa } \\
\text { (lexA/NA1000) }\end{array}$ & $\begin{array}{c}\text { Expressão relativa } \\
\text { (RM20/NA1000) }\end{array}$ & $\begin{array}{c}\text { Expressão relativa } \\
\text { (CC_3225/NA1000) }\end{array}$ \\
\hline CC_2433 & $0.1( \pm 0.0)$ & $2.1( \pm 1.1)$ & $0,114( \pm 0,02)$ \\
dnaB & $0.3( \pm 0.1)$ & $0.58( \pm 0.13)$ & $0,000032( \pm 0,000046)$ \\
(CC_1665) & & & \\
\hline
\end{tabular}

Tabela 9 - Unidades de $\beta$-galactosidase obtidas a partir do promotor do gene rho nas cepas NA1000, RM20 e CC_3225.

\begin{tabular}{ll}
\hline Cepa & Unidades de b-galactosidase \\
\hline NA1000 & $923,34( \pm 411,8)$ \\
RM20 & $805,2( \pm 236,1)$ \\
CC_3225 & $942,89( \pm 240,3)$ \\
\hline
\end{tabular}

Observamos que a cepa mutante RM20 apresenta expressão relativamente reduzida de dnaB, mas não de CC_2433; o porquê deste fato ainda não é muito claro, mesmo se considerarmos a provável função de CC_3037 e CC_3038 como membros de um sistema toxina-antitoxina. 
Já na cepa deficiente em CC_3225 observamos expressão reduzida de ambos os genes se compararmos com a expressão da cepa selvagem NA1000, notadamente do gene $d n a B$. A expressão incrivelmente reduzida de $d n a B$ demonstraria a ocorrência de um knockdown deste gene na cepa CC_3225, o que poderia indicar que o mutante de dnaB em $C$. crescentus seja viável. A redução da expressão de dnaB em CC_3225 é mais significativa do que àquela observado para a cepa deficiente em lexA, o que pode significar que os dois genes atuem em uma mesma via ativando sua expressão. Estes dados são muito recentes e mais experimentos são necessários para entender a regulação da transcrição destes genes. Este assunto é muito interessante e ainda está em aberto.

A fim de melhor compreender a função da repressão de CC_2433 como parte da resposta SOS, iniciamos a construção de um mutante para este gene. Até o momento não fomos capazes de obter uma cepa deficiente para CC_2433. Testamos por PCR diagnóstico setenta e cinco clones sensíveis a canamicina e resistentes a sacarose após as seleções adequadas, e nenhum deles possuía deleção em CC_2433. Esta JAL pode, portanto, codificar uma proteína essencial para C. crescentus. 


\subsection{Relações entre danos e reparo de DNA e ciclo celular em $C$. crescentus}

Umas das características interessantes de $C$. crescentus é seu ciclo celular dimórfico. Isso permite a obtenção de culturas sincronizadas, o que a torna um excelente modelo procarionte para estudos das relações entre danos ao DNA, seu reparo e ciclo celular. O isolamento de células móveis a partir de uma cultura nos permite acompanhar $C$. crescentus pelo ciclo celular e é uma técnica bem estabelecida em laboratórios em todo o mundo. Este trabalho descreve pela primeira vez sua realização em nosso laboratório e abre perspectivas em um campo ainda muito pouco explorado em bactérias, que é o estudo das respostas do ciclo celular a danos no genoma em bactérias.

Para determinar como $C$. crescentus se porta frente a danos em seu DNA induzidos nas diferentes fases do ciclo, primeiramente determinamos o efeito de sensibilidade à irradiação. Neste experimento empregamos como agente indutor de danos a luz UVC, na dose de $150 \mathrm{~J} / \mathrm{m}^{2}$, que resulta em aproximadamente $10 \%$ de sobrevivência em células não sincronizadas. Como podemos observar na figura 30, ocorre um ligeiro aumento na sobrevivência quando as células são irradiadas a partir de 90 minutos após seu isolamento. Dados da literatura apontam que em 30 minutos uma célula móvel já perdeu seu flagelo e em 60 minutos já se inicia a síntese de DNA (Domian et al., 1999). Provavelmente, células em fase $S$ ou em final de $S$ possuem maior disponibilidade de DNA para que o reparo recombinacional ocorra, usando uma fita não danificada como molde. Além disso, o bloqueio de replicação de DNA por lesões no DNA pode levar ao surgimento de regiões de DNA simples fita e conseqüente ativação da resposta SOS. A participação do reparo recombinacional e indução de resposta SOS podem, portanto, explicar a maior resistência de células irradiadas quando a maior parte das células está em processo de replicação de seu genoma. 


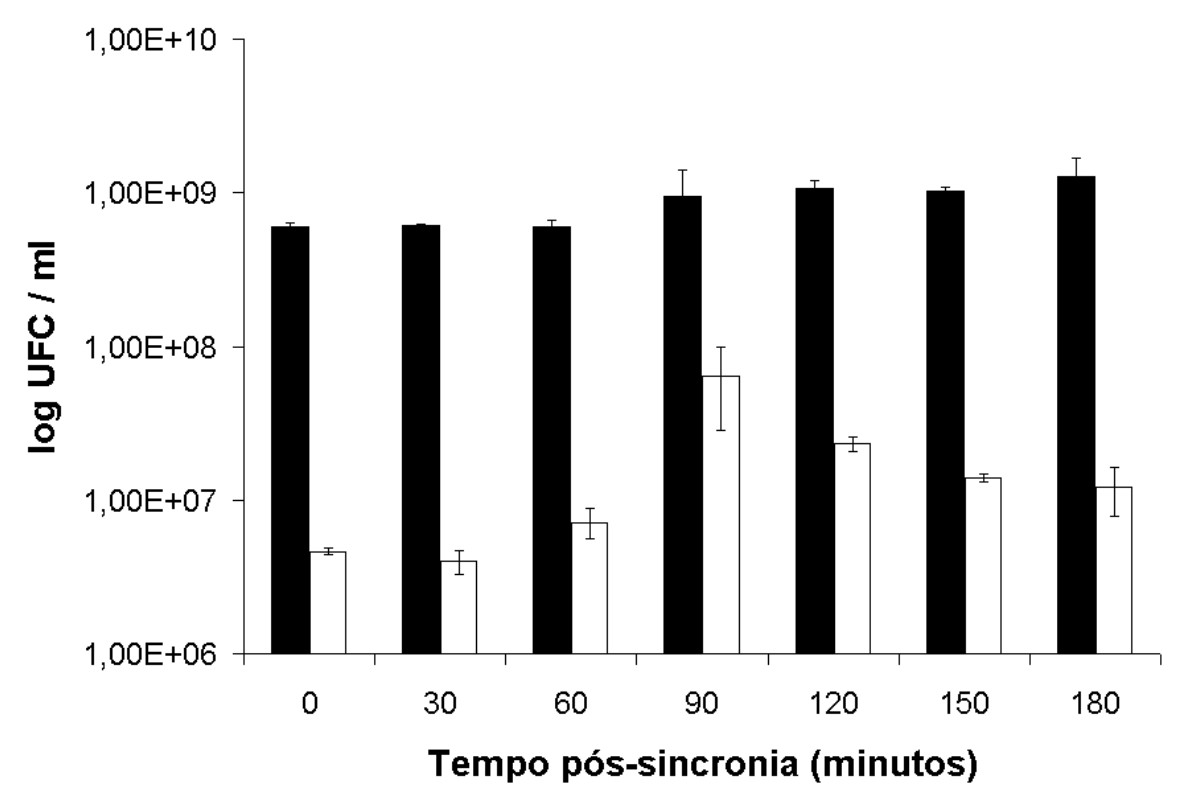

Figura 30 - Sobrevivência da cepa NA1000 irradiada em tempos crescentes após a sincronização. Barras pretas: controle não irradiado, barras brancas: células irradiadas com $150 \mathrm{~J} / \mathrm{m}^{2}$ de luz UVC nos tempos indicados pós-sincronia. A figura representa médias e desvios padrões de pelo menos três experimentos diferentes.

Possuímos em nosso laboratório várias cepas mutantes de $C$. crescentus deficientes em genes de reparo, como os deficientes nos genes uvrA, uvrB e uvrC (Marques, 2008) da via de reparo NER e imUA e dnaE2 deficientes em síntese translesão (Galhardo et al., 2005). Para melhor entender como $C$. crescentus se comporta frente a danos no DNA em relação à progressão do ciclo celular, decidimos empregá-las.

$\mathrm{Na}$ figura 31, apresentamos resultados de sobrevivência de células com deficiências em NER frente à irradiação com luz UVC. Como podemos observar, as cepas deficientes em NER são altamente sensíveis a irradiação com UVC. Baseado nestes resultados e outros do próprio laboratório, os demais experimentos foram realizados com doses relativamente equitóxicas de luz UVC: $15 \mathrm{~J} / \mathrm{m}^{2}$ para as cepas deficientes em NER, $90 \mathrm{~J} / \mathrm{m}^{2}$ para as deficientes em TLS e $150 \mathrm{~J} / \mathrm{m}^{2}$ para NA1000. 


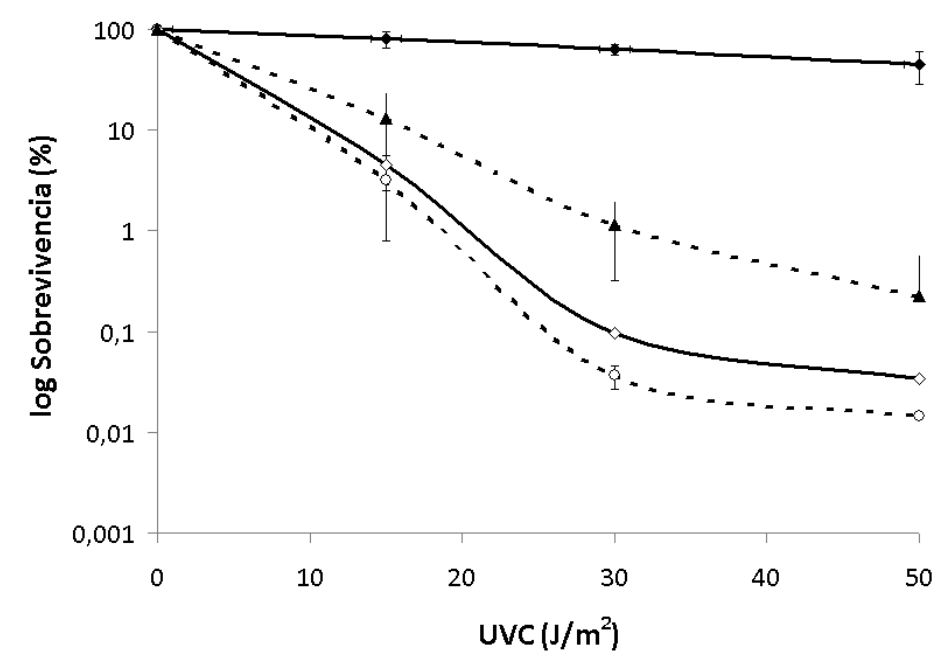

Figura 31 - Sobrevivência das cepas NA1000, uvrA, uvrB e uvrC frente à irradiação com luz UVC. A figura representa médias e desvios padrões de pelo menos três experimentos diferentes. As doses de UVC se encontram indicadas na figura. Linha cheia com losango cheio: NA1000, linha tracejada com círculo vazio: uvrA, linha cheia com losango vazio: uvrB, linha tracejada com triângulo cheio: uvrC.

Até o início de 2009 não possuíamos uma metodologia adequada para analisar o conteúdo de DNA em $C$. crescentus, e conseqüentemente o ciclo desta bactéria. Testes iniciais realizados com a incorporação de nucleotídeos marcados radioativamente não foram bem sucedidos, possivelmente devido à dificuldade de transporte dos precursores por $C$. crescentus (G. Marczynski, comunicação pessoal). Decidimos então investir na técnica de análise de conteúdo de DNA por citometria de fluxo, que é realizada rotineiramente em laboratórios de $C$. crescentus em todo o mundo. Basicamente, incubamos as células fixadas de $C$. crescentus com um intercalante de DNA capaz de ser excitado pelo laser do citômetro de fluxo, e assim determinar o conteúdo de DNA em cada célula de uma dada amostra; desse modo podemos inferir o ciclo celular da população bacteriana. O resultado final é dado como um gráfico contendo a distribuição do conteúdo de DNA em todas as células da amostra. Apesar de aparentemente simples, esta técnica possui diferenças básicas de detecção entre células bacterianas e eucariontes; a mais importante delas está na determinação da população de células a ser considerada pela análise. Para células eucariontes, a população é separada facilmente de debris pela análise do tamanho individual de cada célula; isso não pode ser realizado em bactérias, pois o tamanho de uma célula bacteriana está abaixo do limite de detecção do aparelho e é, portanto, facilmente confundida com debris. A separação da população de células a ser considerada é feita aqui 
pela intensidade de fluorescência após a incubação com o intercalante de DNA: debris possuem algum nível de auto-fluorescência, mas é bem inferior àquele obtido com células contendo DNA marcado. Apesar das dificuldades iniciais no estabelecimento desta técnica, um estágio no laboratório da Dra. Kathleen Ryan, na University of Califórnia, Berkeley, permitiu que dominássemos os principais pontos da metodologia.

Na figura 32 apresentamos os principais resultados obtidos com as células NA1000, proficientes em reparo e sincronizadas. Como pode ser observado, células não irradiadas apresentam um perfil, imediatamente após o isolamento das células móveis ( $\mathrm{t}=0$ minutos), no qual a maior parte encontra-se em fase G1 do ciclo. Com a progressão deste, as células passam pelas fases S (maioria em 60 minutos) e G2 (claramente observada em 90 e 120 minutos). Em tempos maiores já observamos parte das células tendo completado sua divisão, com o reaparecimento de células em fase G1 a partir de 120 minutos.

As células irradiadas com $15 \mathrm{~J} / \mathrm{m}^{2}$ apresentam atraso na progressão do ciclo, aparentemente com células em fase $S$ de 60 a 120 minutos, e células que completaram a divisão (em fase G1 novamente) aparecem após 150 minutos. Em doses maiores (90 e 150 $\mathrm{J} / \mathrm{m}^{2}$ ) há um aparente bloqueio das células em fase G1 durante o período total analisado (3 horas). Nesse caso, os dados indicam que a maior parte das células provavelmente não completa o ciclo de divisão celular.

Nas figuras 33, 34 e 35 apresentamos experimentos similares com cepas deficientes em NER (uvrA, uvrB e uvrC). Os dados de progressão do ciclo em células não irradiadas são semelhantes aos obtidos com a cepa controle, apesar de observarmos a ocorrência de um ciclo mais lento (mais facilmente observado em uvrA). Entretanto, claramente observamos o bloqueio em fase $\mathrm{G} 1$ já em doses de irradiação de $15 \mathrm{~J} / \mathrm{m}^{2}$, nas três cepas analisadas.

Para células deficientes em genes envolvidos em TLS, imuA e dnaE2, os dados são apresentados nas figuras 36 e 37. Basicamente, observamos o mesmo padrão de progressão do ciclo celular em células não irradiadas do que as outras cepas. Por outro lado, quando as células são irradiadas o padrão é similar ao encontrado em células selvagens: em doses baixas $\left(15 \mathrm{~J} / \mathrm{m}^{2}\right)$ : as células são capazes de progredir no ciclo, apesar de certo atraso; em doses maiores $\left(90 \mathrm{~J} / \mathrm{m}^{2}\right)$, as células ficam bloqueadas em fase $\mathrm{G} 1$ do ciclo. 

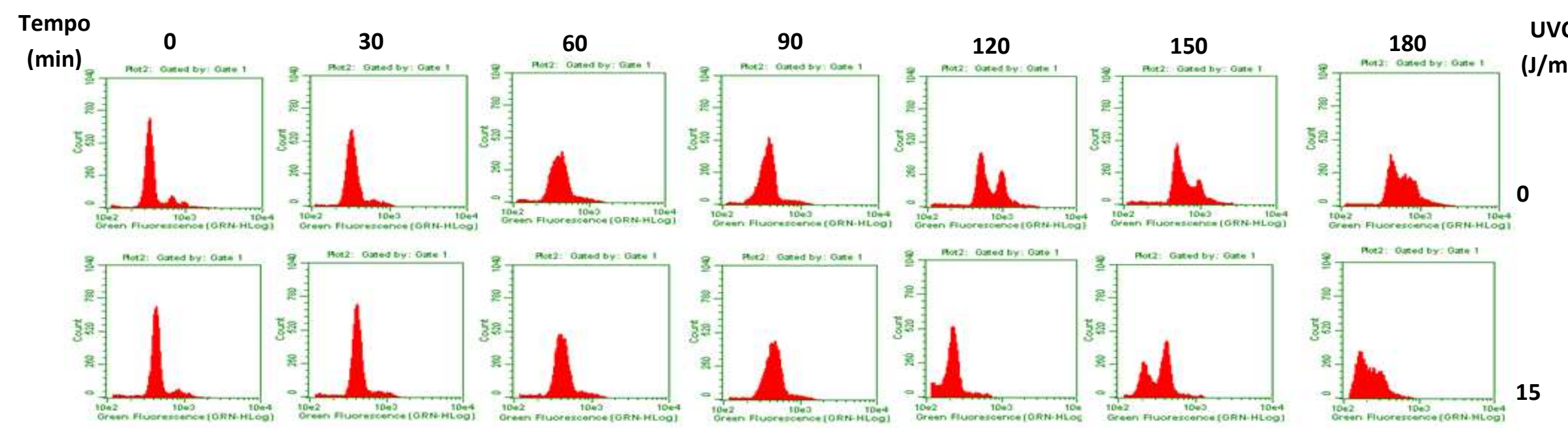

UVC
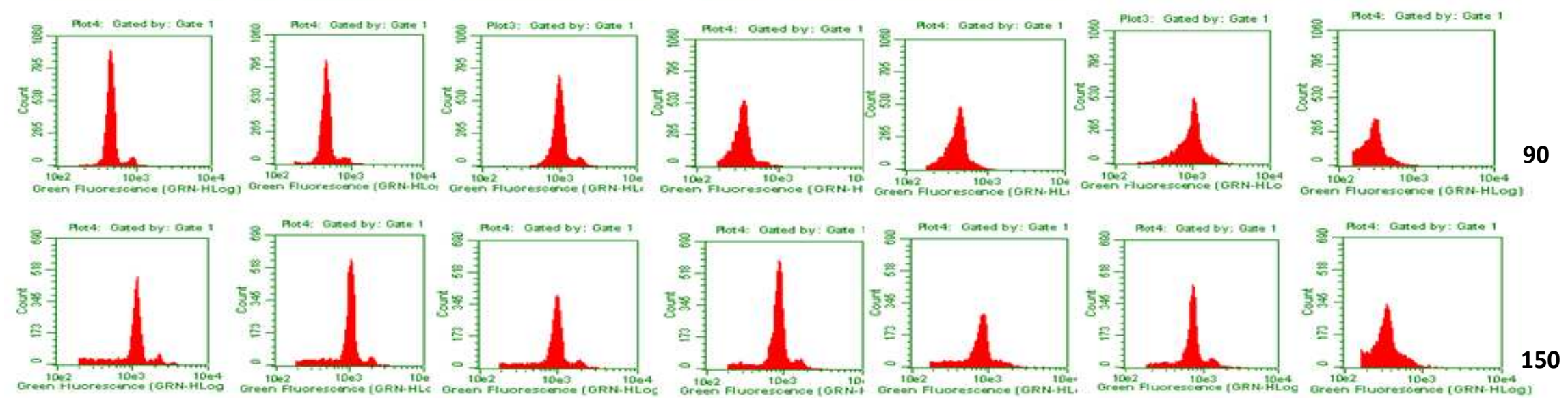

Figura 32 - Exemplos demonstrativos do perfil de progressão do ciclo celular da cepa NA1000 sincronizada e irradiada ou não com luz UVC. A irradiação foi realizada no tempo zero após a sincronização e amostras foram coletadas em tempos crescentes após a sincronização celular; os tempos após a sincronização estão indicados na figura. As células foram irradiadas com $0 \mathrm{~J} / \mathrm{m}^{2}, 15 \mathrm{~J} / \mathrm{m}^{2}, 90 \mathrm{~J} / \mathrm{m}^{2}$ e $150 \mathrm{~J} / \mathrm{m}^{2}$. Eixo das ordenadas: contagem de células, eixo das abscissas: fluorescência verde (escala logarítmica), que indica a quantidade de DNA por célula. 
120

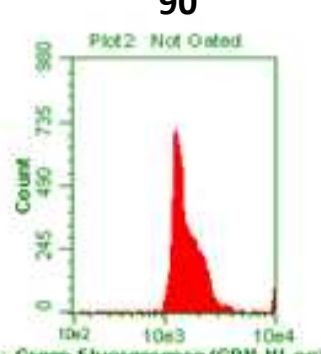

0 -

$\circ \frac{1}{20}$
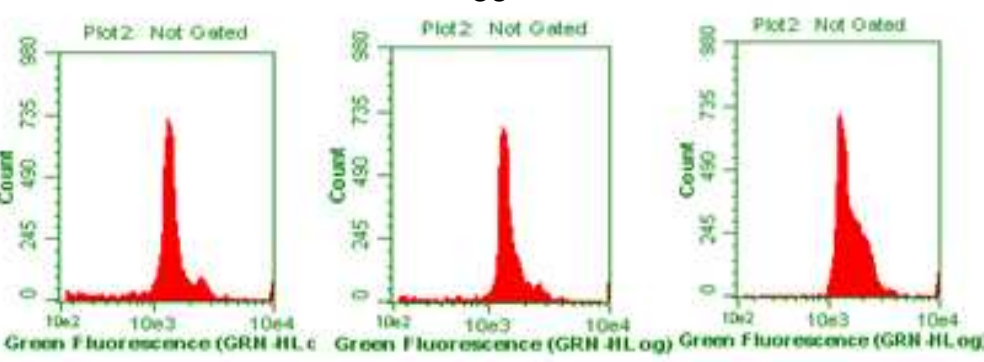
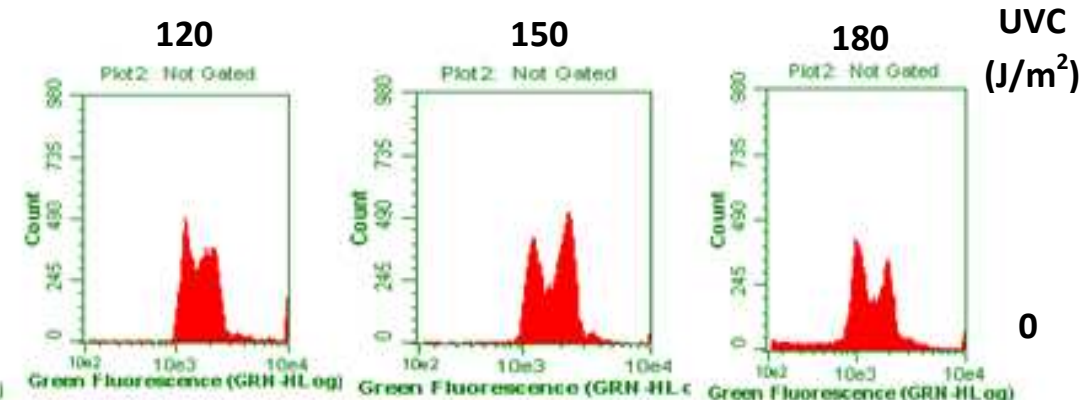

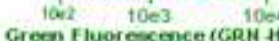
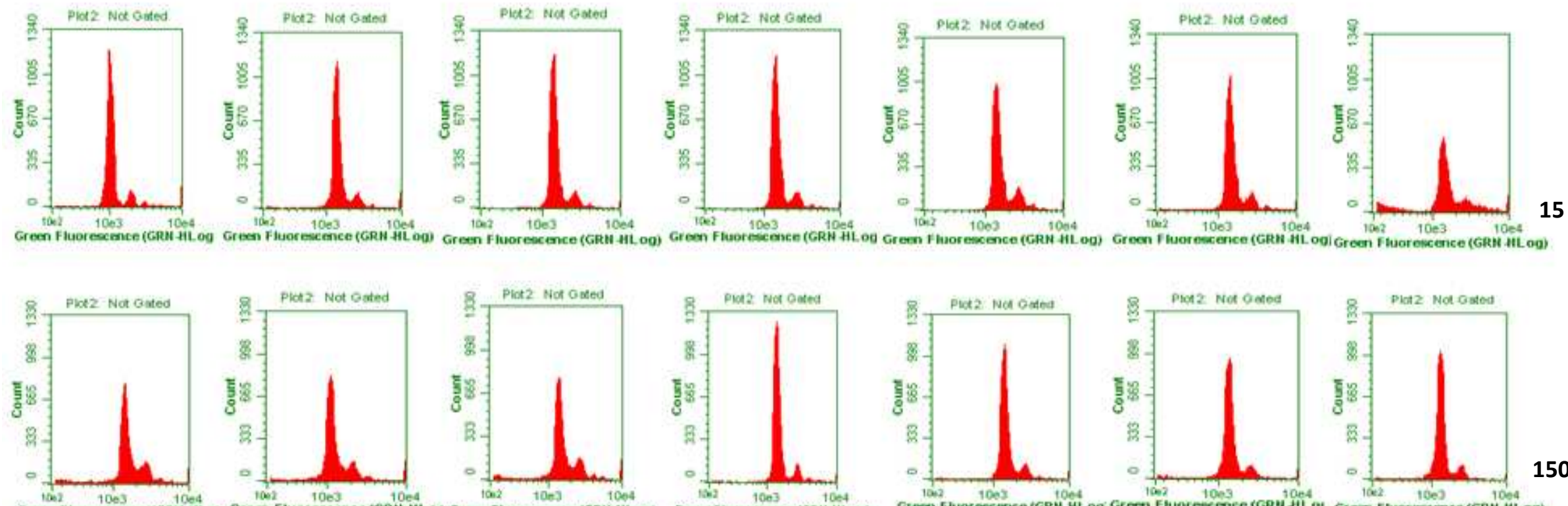

Figura 33 - $\quad$ Exemplos demonstrativos do perfil de progressão do ciclo celular da cepa uvrA sincronizada e irradiada ou não com luz UVC. $A$ irradiação foi realizada no tempo zero após a sincronização e amostras foram coletadas em tempos crescentes após a sincronização celular; os tempos após a sincronização estão indicados na figura. As células foram irradiadas com $0 \mathrm{~J} / \mathrm{m}^{2}, 15 \mathrm{~J} / \mathrm{m}^{2}$ e $150 \mathrm{~J} / \mathrm{m}^{2}$. Eixo das ordenadas: contagem de células, eixo das abscissas: fluorescência verde (escala logarítmica), que indica a quantidade de DNA por célula. 


\section{Tempo}

(min)
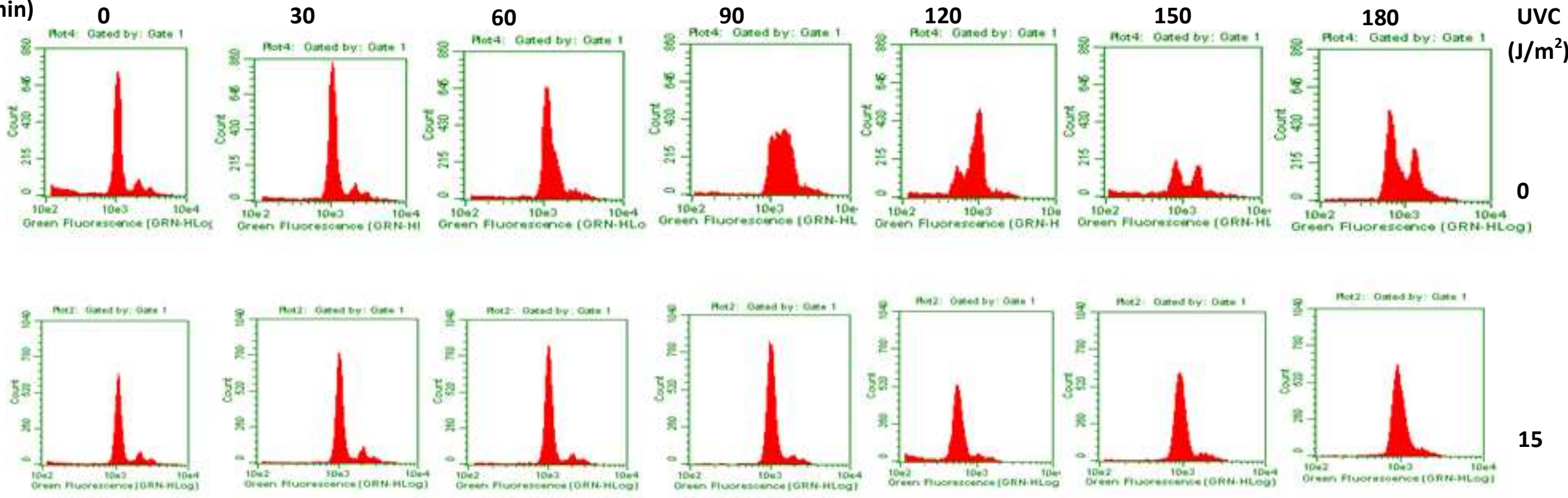

15
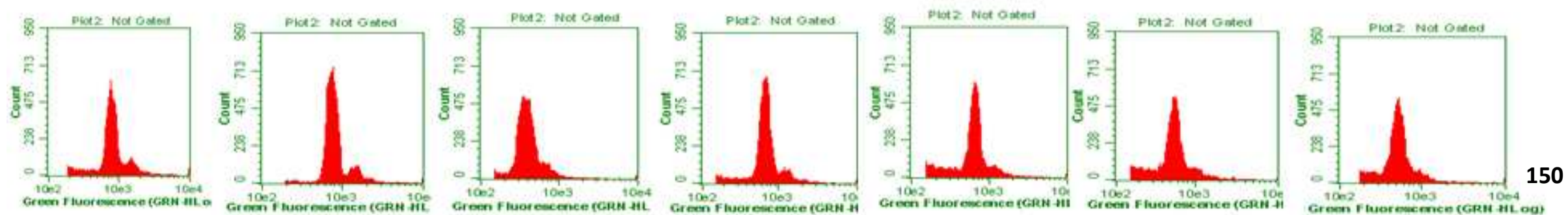

Figura 34 - Exemplos demonstrativos do perfil de progressão do ciclo celular da cepa uvrB sincronizada e irradiada ou não com luz UVC. A irradiação foi realizada no tempo zero após a sincronização e amostras foram coletadas em tempos crescentes após a sincronização celular; os tempos após a sincronização estão indicados na figura. As células foram irradiadas com $0 \mathrm{~J} / \mathrm{m}^{2}, 15 \mathrm{~J} / \mathrm{m}^{2}$ e $150 \mathrm{~J} / \mathrm{m}^{2}$. Eixo das ordenadas: contagem de células, eixo das abscissas: fluorescência verde (escala logarítmica), que indica a quantidade de DNA por célula. 


\section{Tempo}

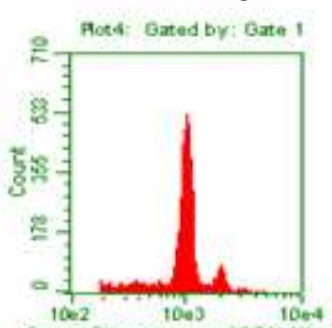

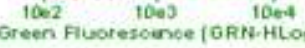

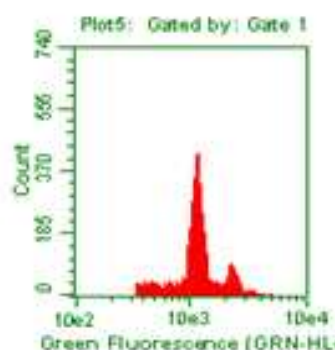

Green Fluoresognce (GRN-HLOS

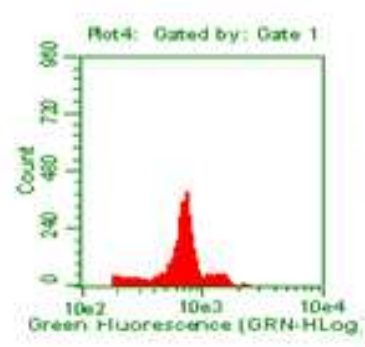

30
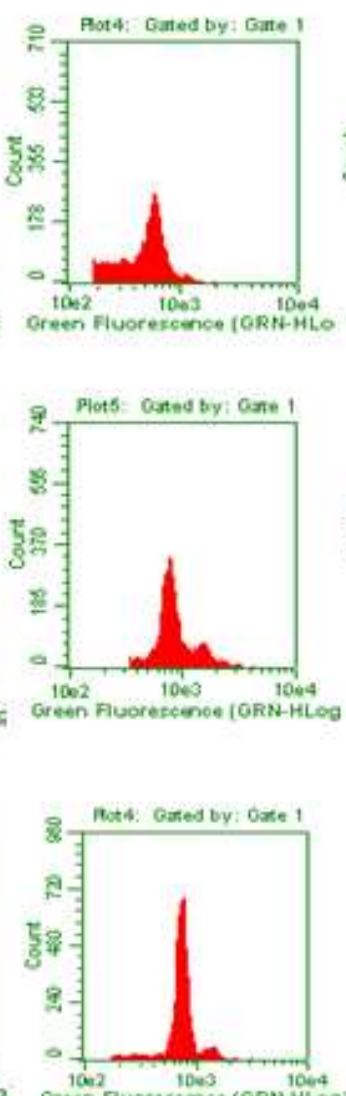

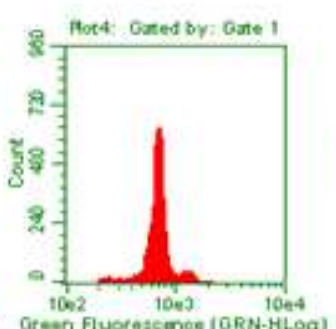

60
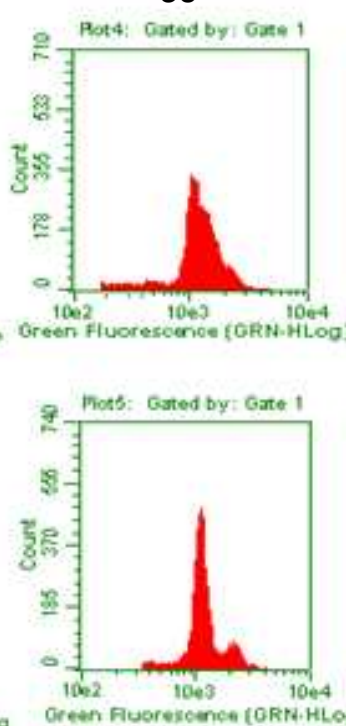

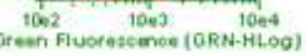

90

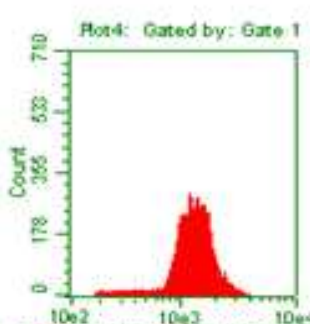

Geen Fluoresomser (GRN. HLo

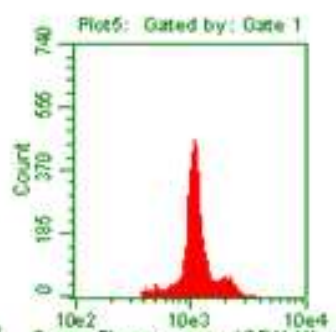

1002 10e3 10.4

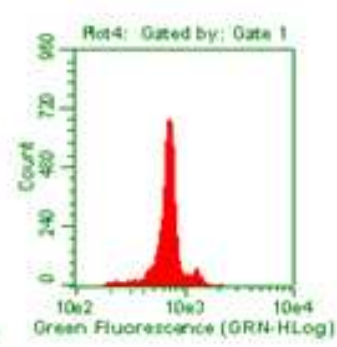

120
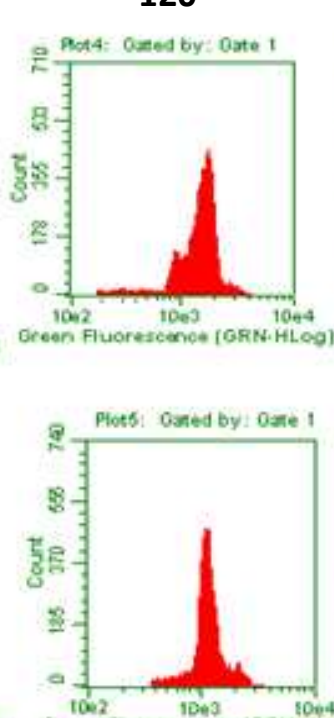

Geos 1003
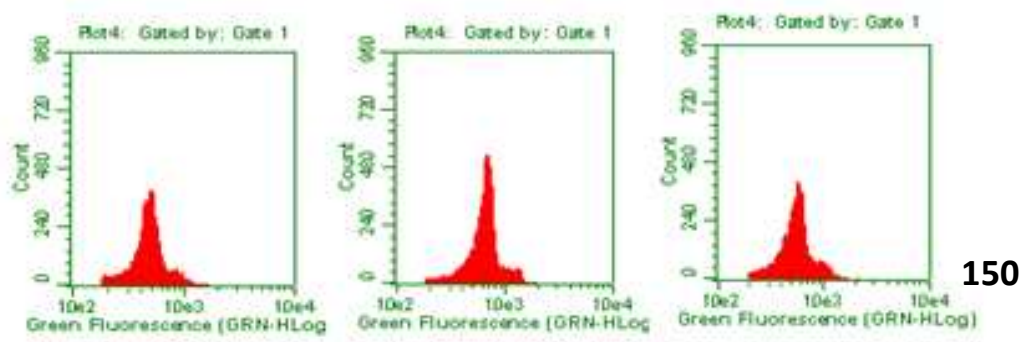

Figura 35 - Exemplos demonstrativos do perfil de progressão do ciclo celular da cepa uvrC sincronizada e irradiada ou não com luz UVC. $A$ irradiação foi realizada no tempo zero após a sincronização e amostras foram coletadas em tempos crescentes após a sincronização celular; os tempos após a sincronização estão indicados na figura. As células foram irradiadas com $0 \mathrm{~J} / \mathrm{m}^{2}, 15 \mathrm{~J} / \mathrm{m}^{2}$ e $150 \mathrm{~J} / \mathrm{m}^{2}$. Eixo das ordenadas: contagem de células, eixo das abscissas: fluorescência verde (escala logarítmica), que indica a quantidade de DNA por célula. 
Tempo

(min)
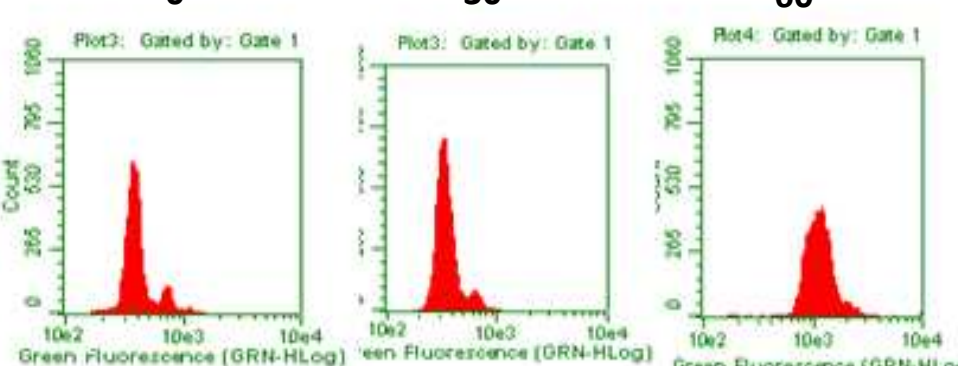

60

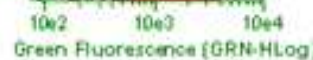

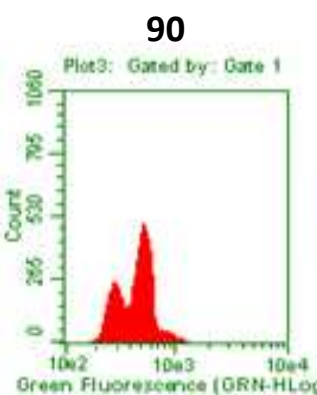

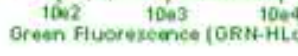
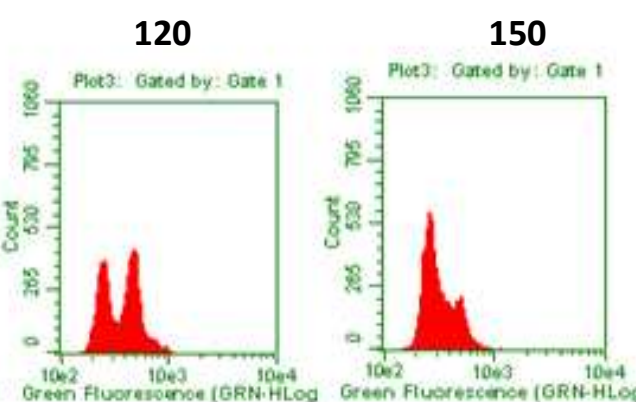

50
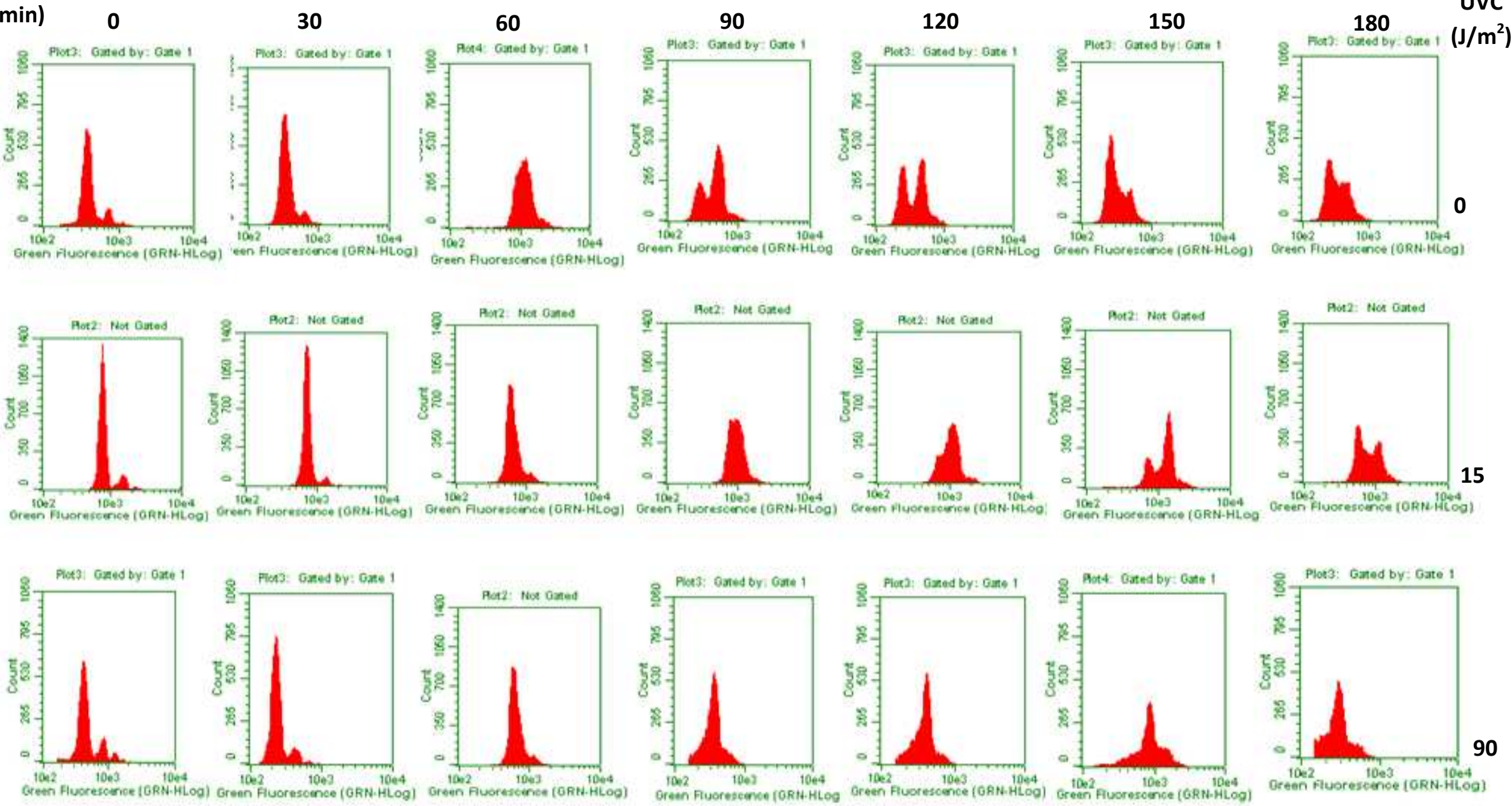
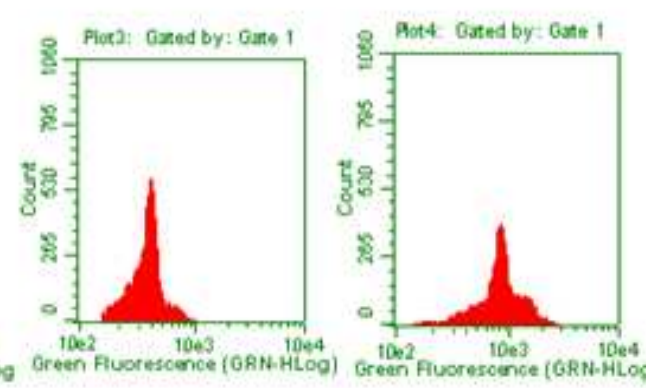

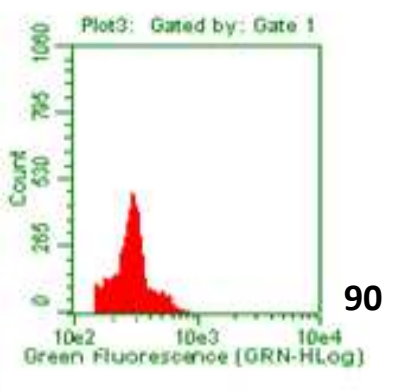

Figura 36 -

Exemplos demonstrativos do perfil de progressão do ciclo celular da cepa imuA sincronizada e irradiada ou não com luz UVC. $A$ irradiação foi realizada no tempo zero após a sincronização e amostras foram coletadas em tempos crescentes após a sincronização celular; os tempos após a sincronização estão indicados na figura. As células foram irradiadas com $0 \mathrm{~J} / \mathrm{m}^{2}, 15 \mathrm{~J} /{ }^{2}$ e $90 \mathrm{~J} / \mathrm{m}^{2}$. Eixo das ordenadas: contagem de células, eixo das abscissas: fluorescência verde (escala logarítmica), que indica a quantidade de DNA por célula. 


\section{Tempo}

(min)
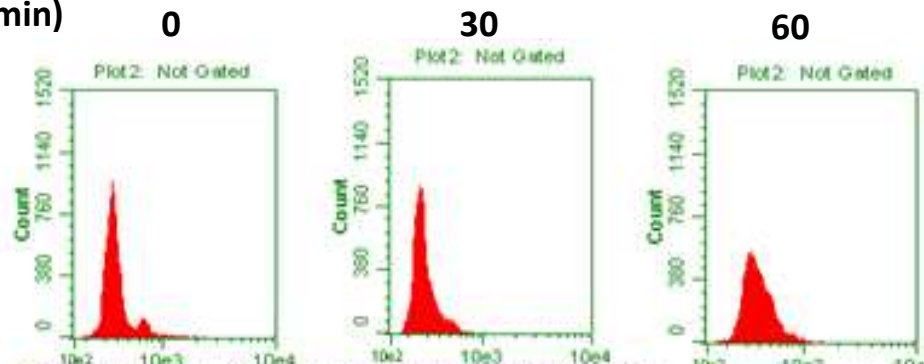

Groent ruoresecence (GRAit
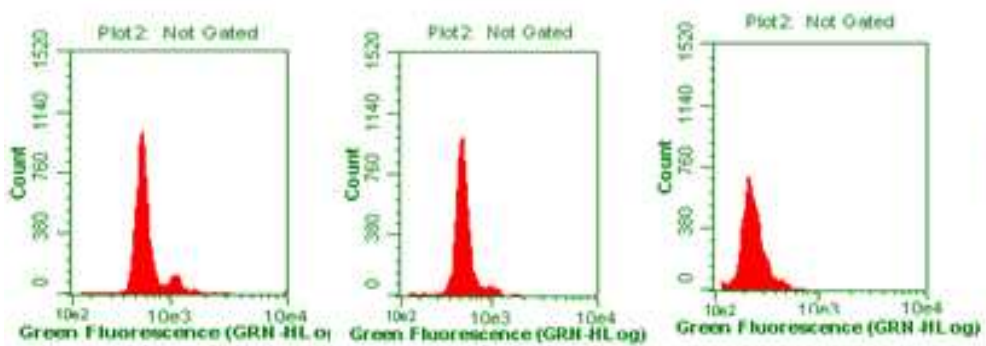

Greon Fiturerescence (GRHitit
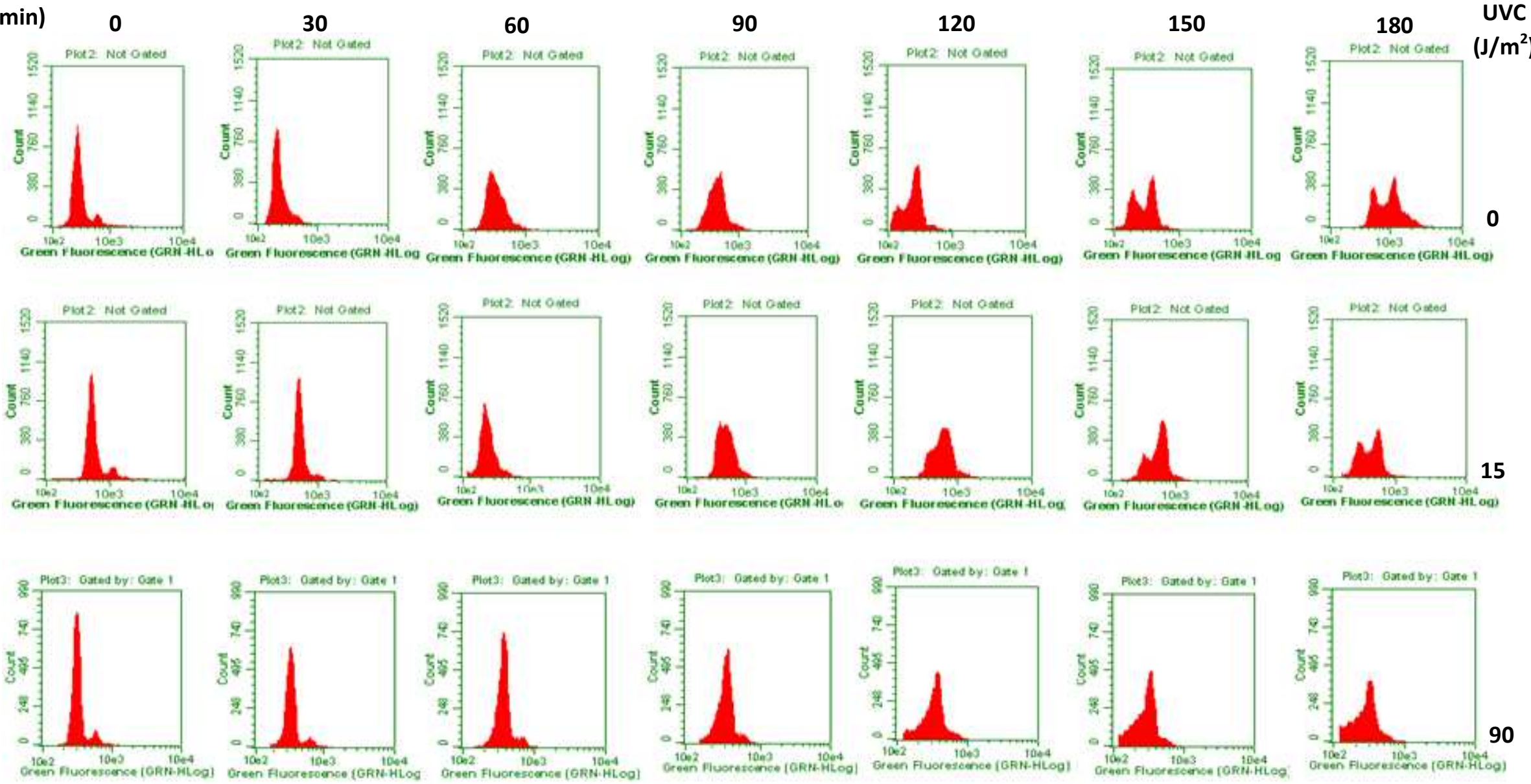

Figura 37 -

Exemplos demonstrativos do perfil de progressão do ciclo celular da cepa dnaE2 sincronizada e irradiada ou não com luz UVC. $A$ irradiação foi realizada no tempo zero após a sincronização e amostras foram coletadas em tempos crescentes após a sincronização celular; os tempos após a sincronização estão indicados na figura. As células foram irradiadas com $0 \mathrm{~J} / \mathrm{m}^{2}, 15 \mathrm{~J} / \mathrm{m}^{0}$ e $90 \mathrm{~J} / \mathrm{m}^{2}$. Eixo das ordenadas: contagem de células, eixo das abscissas: fluorescência verde (escala logarítmica), que indica a quantidade de DNA por célula. 
O bloqueio do ciclo provavelmente é causado pelos fotoproddutos induzidos no DNA, o que nos levou a investigar a presença e o reparo de lesões CPDs no DNA destas bactérias. Os CPDs são o principal tipo de lesão gerado no DNA após a irradiação com luz UV, correspondendo à maioria das lesões geradas após tratamento com UVC (revisto por Friedberg et al., 2006).

Para a quantificação destas lesões no DNA de $C$. crescentus após a irradiação com luz UVC, utilizamos um método semelhante ao realizado por Schuch et al. (2009). Como padrão de freqüência de lesões no genoma, empregamos um plasmídeo de tamanho conhecido (pCMUT, Schuch et al., 2009) irradiado com 15 e $150 \mathrm{~J} / \mathrm{m}^{2}$ de UVC e os sítios sensíveis à enzima T4-endonuclease V (T4-endo SS) foram quantificados pelo ensaio de relaxamento de plasmídeo. Basicamente, a ação da T4-endonuclease $\mathrm{V}$ cliva o DNA na região de CPDs e isso converte o DNA plasmidial super enovelado (forma I) em circular relaxado (forma II) (figura 38 A). A quantificação dos sítios sensíveis nesse DNA de tamanho conhecido foi empregada como padrão para quantificar lesões no genoma de $C$. crescentus, através de imuno slot-blot utilizando anticorpos específicos para a lesão (Figura 38 B). Utilizando o DNA plasmidial irradiado, comparamos a intensidade da banda referente ao anticorpo anti-CPD com o número real de CPDs em células de $C$. crescentus.
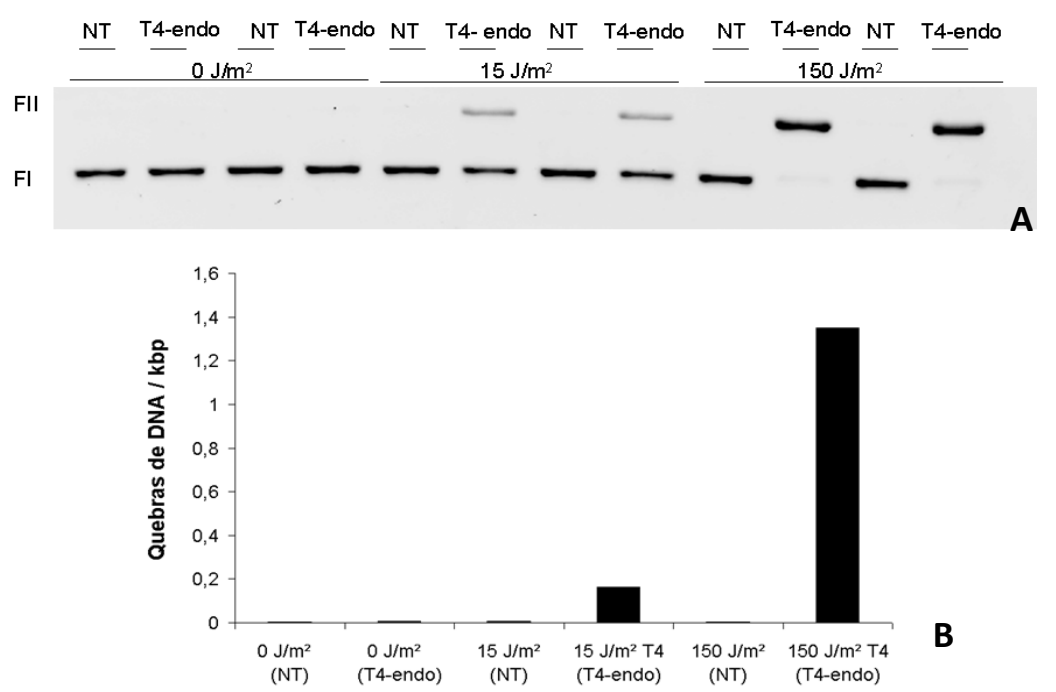

Figura 38 - Determinação do número de lesões CPD no DNA do plasmídeo pCMUT após a irradiação com luz UVC. A: migração eletroforética do DNA plasmidial após o tratamento indicado em gel de agarose; B: quantificação dos sítios sensiveis a T4endonuclease $V$ a partir dos dados de $A$. NT indica não tratado com T4-endonuclease $V$ e T4-endo indica a forma tratada; FI indica a forma superenovelada do plasmídeo $e$ a F II indica a forma circular relaxada. As doses de UVC estão indicadas na figura. 
Foram quantificadas as lesões CPDs presentes nos genomas das cepas bacterianas após sincronização e irradiação (sempre no tempo zero). Analisamos também a remoção das lesões após 60 e 120 minutos. Na figura 39 demonstramos os resultados obtidos com a cepa selvagem NA1000. A primeira observação que nos chama a atenção é a presença de um maior número de lesões CPD no DNA do plasmídeo pCMUT do que no DNA genômico das células irradiados com uma mesma dose de UVC. Isso provavelmente se deve ao fato das irradiações serem realizadas em células íntegras de $C$. crescentus e não em DNA nu como no caso do plasmídeo. Essa observação será verdadeira para todos os experimentos que utilizam o anticorpo. Na quantificação do número de lesões CPDs presentes no genoma da cepa NA1000 observamos, conforme o esperado, que este é menor quando as células são irradiadas com uma dose baixa de luz UVC $\left(15 \mathrm{~J} / \mathrm{m}^{2}\right)$. A irradiação com uma dose maior (150 $\mathrm{J} / \mathrm{m}^{2}$ ) promove um número proporcionalmente maior de CPDs, ou seja, uma dose 10 vezes maior promove o aparecimento de aproximadamente 10 vezes mais CPDs por kbp. O reparo destas lesões é muito eficiente na dose de $15 \mathrm{~J} / \mathrm{m}^{2}$, como podemos observar pela redução do número de lesões após 60 e 120 minutos (cerca de 90\% das lesões foram removidas nesse período); o reparo também ocorre após a irradiação com $150 \mathrm{~J} / \mathrm{m}^{2}$, mas de uma forma bem menos eficiente e lenta (após 120 minutos foram removidos aproximadamente 75\% dos CPDs gerados). Isso provavelmente se deve ao grande número de lesões presentes no genoma, o que poderia saturar a capacidade de reparo da célula. 


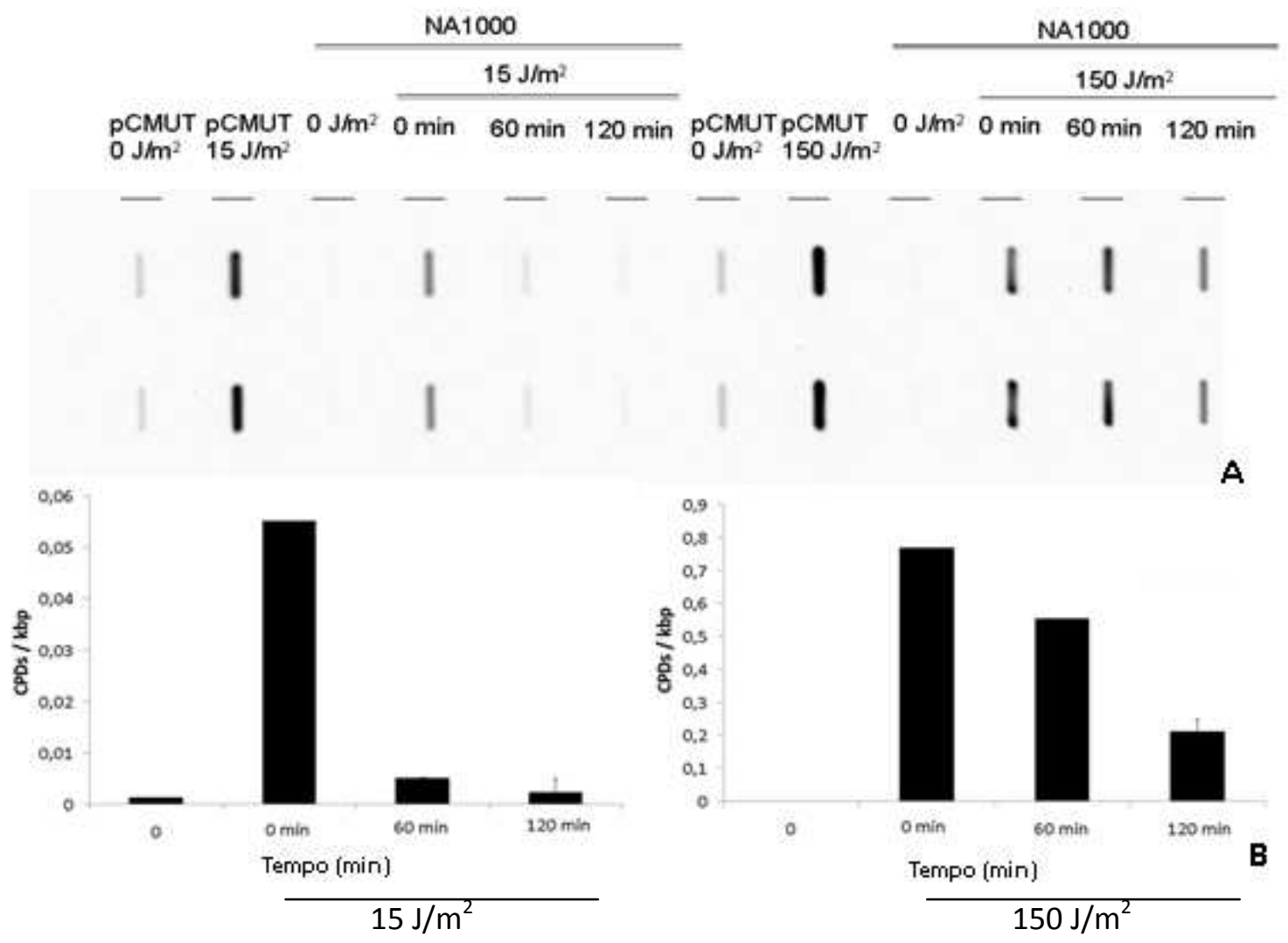

Figura 39 - Determinação imunológica das lesões CPDs presentes no DNA genômico de NA1000 sincronizada e irradiada com luz UVC. As irradiações foram realizadas no tempo zero após a sincronia, e as amostras de DNA foram coletadas nos tempos de 0,60 e 120 minutos após a irradiação. A: Detecção de lesões CPDs através do anticorpo anti-CPD. B: Quantificação das lesões CPDs após a irradiação com as doses e nos tempos indicados.

Nas figuras 40, 41 e 42, apresentamos os resultados referentes a quantificação e reparo de lesões CPDs nas cepas deficiente em NER (uvrA, uvrB e uvrC). Nestes casos existe também um menor número de lesões CPDs após a irradiação com a menor dose de UVC (15 $\mathrm{J} / \mathrm{m}^{2}$ ), conforme observado para a cepa selvagem. A irradiação com $150 \mathrm{~J} / \mathrm{m}^{2}$ gera um número maior de CPDs, sendo a proporcionalidade clara para as cepas uvrA (Figura 40), uvrB (Figura 41) e uvrC (Figura 42. Os desvios podem ser apenas variações experimentais e não ter significado real. O reparo das lesões, apesar das variações, parece ser ineficiente nas três cepas testadas, como era esperado. 

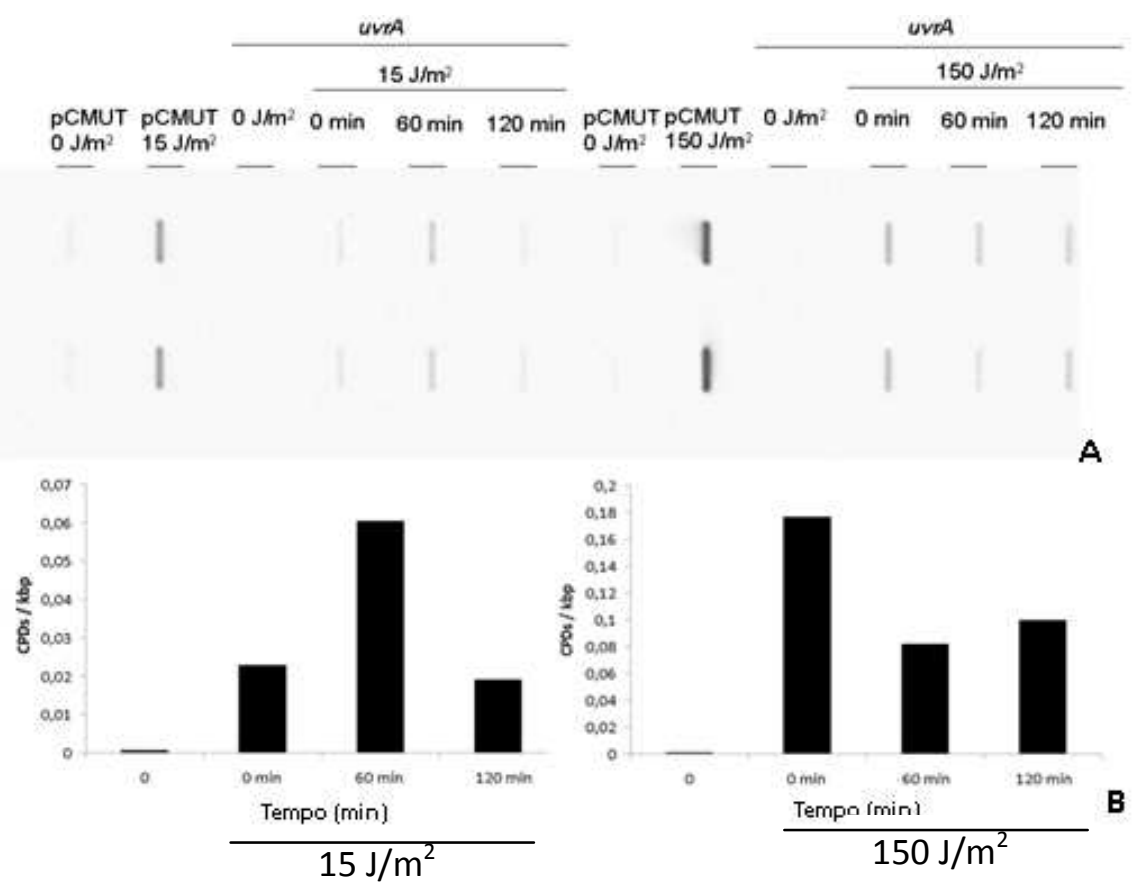

Figura 40 - Determinação imunológica das lesões CPDs presentes no plasmídeo pCMUT e no DNA genômico de uvrA sincronizada e irradiada com luz UVC. As irradiações foram realizadas no tempo zero após a sincronia, e as amostras de DNA foram coletadas nos tempos de 0,60 e 120 minutos após a irradiação. A: Detecção de lesões CPDs através do anticorpo anti-CPD. B: Quantificação das lesões CPDs após a irradiação com as doses e nos tempos indicados.
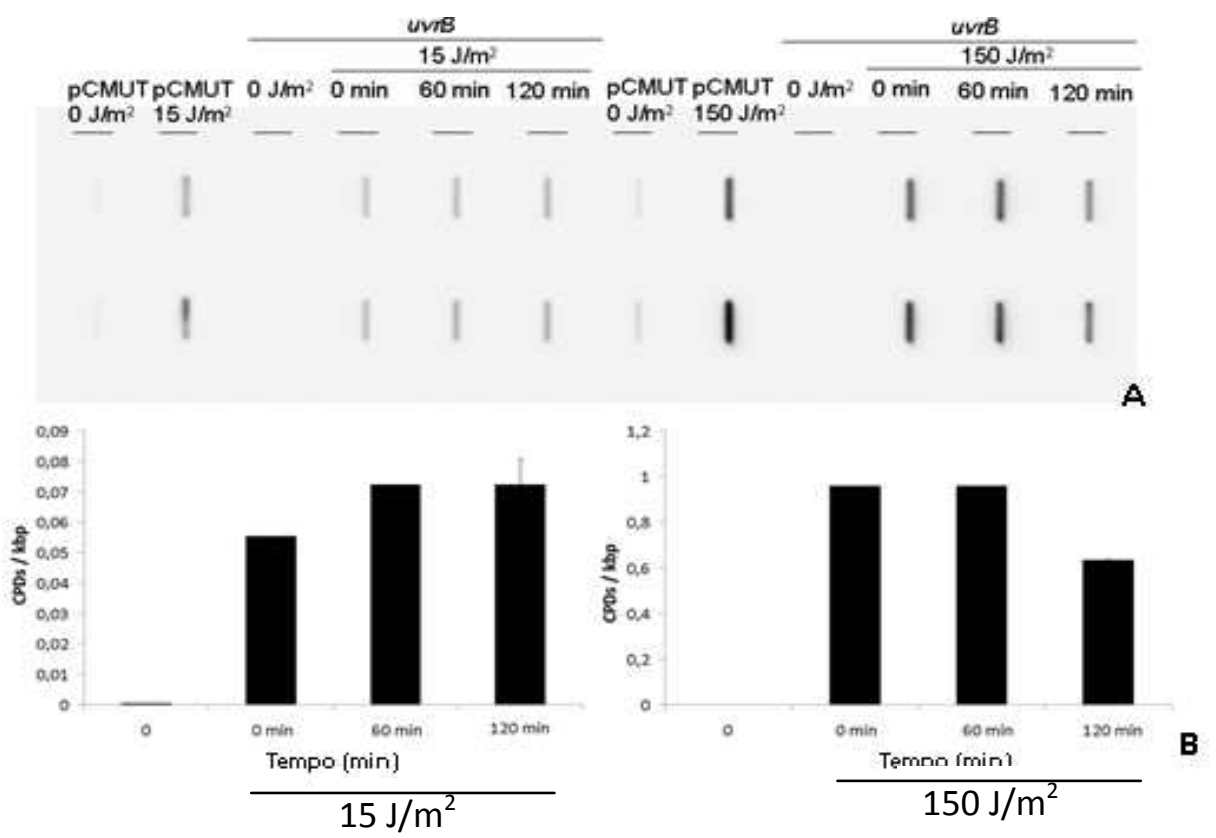

Figura 41 - Determinação imunológica das lesões CPDs presentes no plasmídeo pCMUT e no DNA genômico de uvrB sincronizada e irradiada com luz UVC. As irradiações foram realizadas no tempo zero após a sincronia, e as amostras de DNA foram coletadas nos tempos de 0,60 e 120 minutos após a irradiação. A: Detecção de lesões CPDs através do anticorpo anti-CPD. B: Quantificação das lesões CPDs após a irradiação com as doses e nos tempos indicados. 

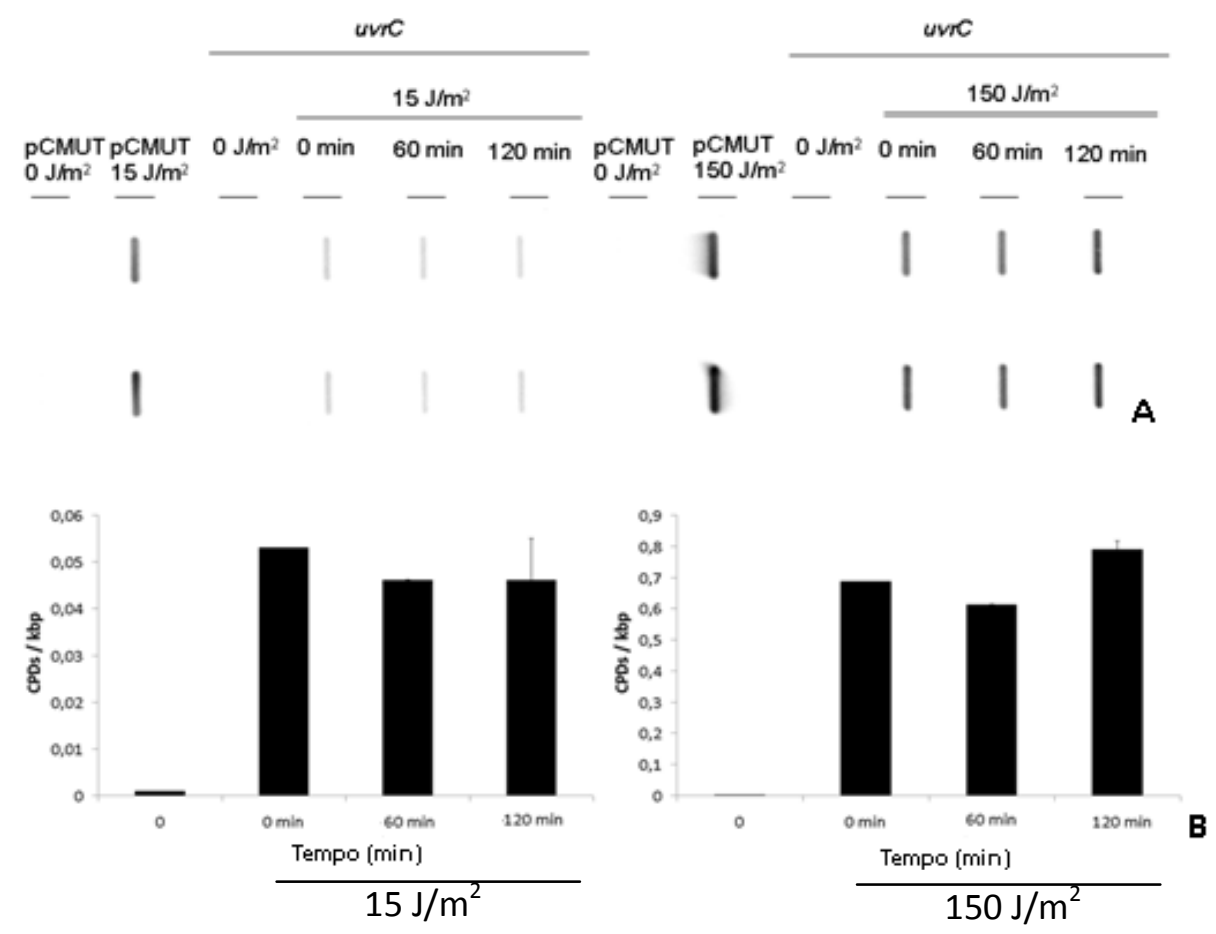

Figura 42 - Determinação imunológica das lesões CPDs presentes no plasmídeo pCMUT e no DNA genômico de uvrC sincronizada e irradiada com luz UVC. As irradiações foram realizadas no tempo zero após a sincronia, e as amostras de DNA foram coletadas nos tempos de 0, 60 e 120 minutos após a irradiação. A: Deteç̧ão de lesões CPDs através do anticorpo anti-CPD. B: Quantificação das lesões CPDs após a irradiação com as doses e nos tempos indicados.

A quantificação das lesões CPDs presentes no genoma das cepas deficientes em TLS (imuA e dnaE2) após a irradiação com diferentes doses de luz UVC se encontra nas figuras 43 e 44. O padrão do número de lesões após a irradiação com $15 \mathrm{~J} / \mathrm{m}^{2}$ e $150 \mathrm{~J} / \mathrm{m}^{2}$ se mantém como nas cepas anteriores, sendo que aqui, assim como nas células deficientes em NER, a proporcionalidade da geração de lesões é tão clara como na NA1000. O que nos chamou a atenção nestas cepas, no entanto, foi o reparo extremamente rápido das lesões nas duas doses, aproximadamente $80 \%$ dos CPDs foram removidos após 60 minutos, sendo que na dose de $150 \mathrm{~J} / \mathrm{m}^{2}$, quase que a totalidade (97\%) havia sido removida após 120 minutos.

Os resultados obtidos até aqui indicam que, pelo menos para as cepas NA1000, imuA e dnaE2, existe outro fator além da presença das lesões CPDs que é responsável pelo bloqueio do ciclo celular após a dose de $150 \mathrm{~J} / \mathrm{m}^{2}$, uma vez que após 2 horas, quase a totalidade destas lesões já foi removida do genoma. 


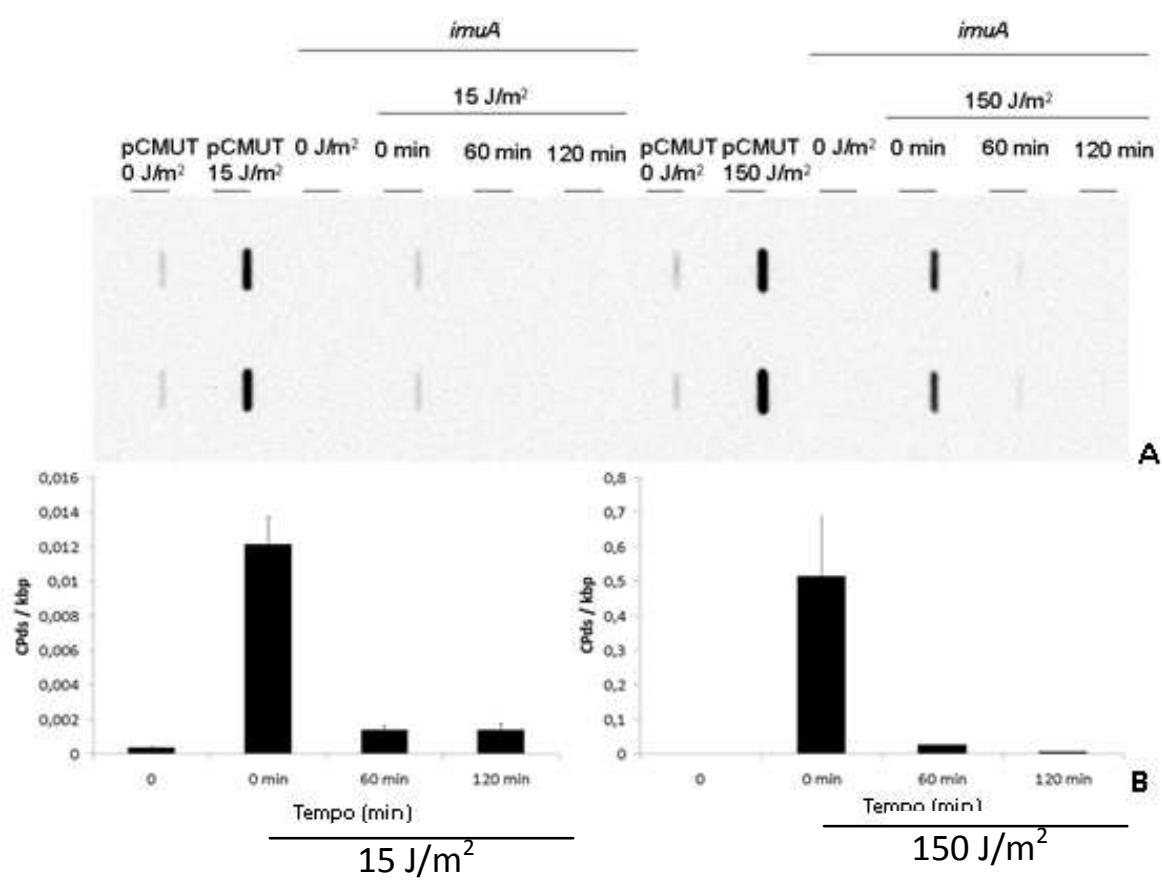

Figura 43 - Determinação imunológica das lesões CPDs presentes no plasmídeo pCMUT e no DNA genômico de imuA sincronizada e irradiada com luz UVC. As irradiações foram realizadas no tempo zero após a sincronia, e as amostras de DNA foram coletadas nos tempos de 0, 60 e 120 minutos após a irradiação. A: Detecção de lesões CPDs através do anticorpo anti-CPD. B: Quantificação das lesões CPDs após a irradiação com as doses e nos tempos indicados.

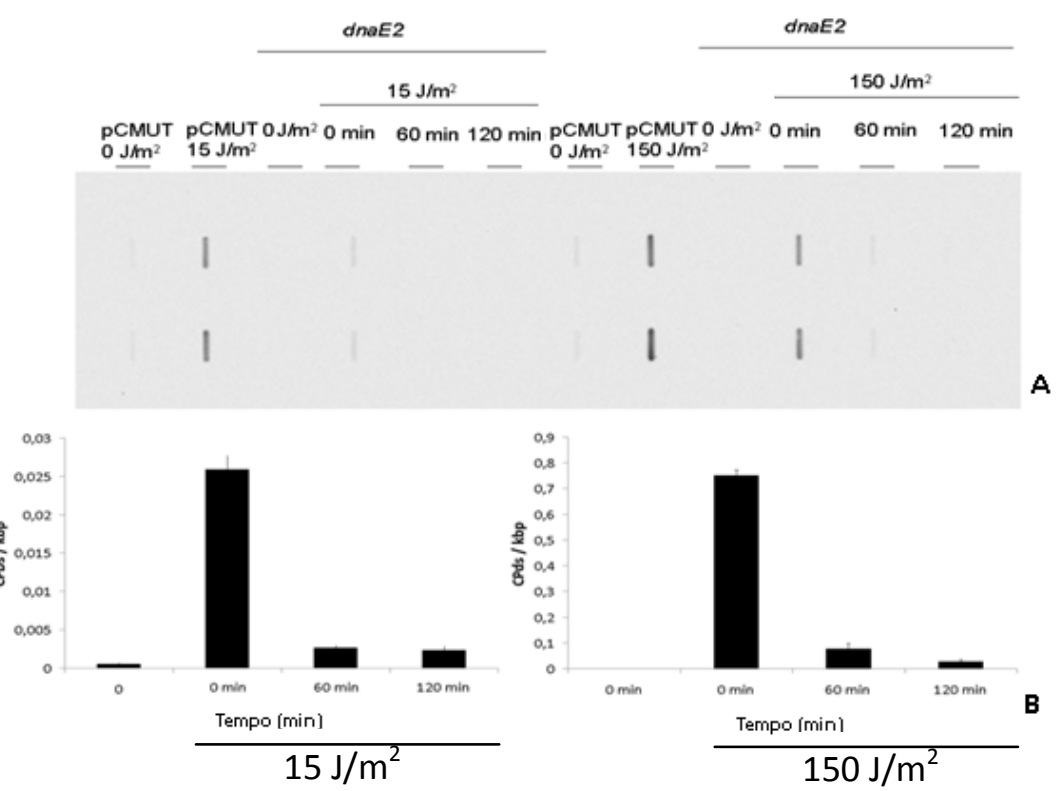

Figura 44 - Determinação imunológica das lesões CPDs presentes no plasmídeo pCMUT e no DNA genômico de dnaE2 sincronizada e irradiada com luz UVC. As irradiações foram realizadas no tempo zero após a sincronia, e as amostras de DNA foram coletadas nos tempos de 0, 60 e 120 minutos após a irradiação. A: Detecção de lesões CPDs através do anticorpo anti-CPD. B: Quantificação das lesões CPDs após a irradiação com as doses e nos tempos indicados. 
A proteína CtrA atua como um dos reguladores de resposta mestres do desenvolvimento de $C$. crescentus. Sua forma ativa é a forma fosforilada, e neste estado, CtrA é capaz de bloquear a replicação do DNA por ser associar a cinco regiões na origem de replicação e bloquear o acesso da proteína iniciadora de replicação DnaA. Além disso, CtrA controla a expressão de 95 genes envolvidos em morfogênese polar, regulação do ciclo celular, biossíntese do flagelo, biossíntese do pilus, montagem do aparato quimiotático e outros processos regulatórios (revisto por Skerker e Laub, 2004). Decidimos, portanto investigar os níveis de RNAm de ctrA após a irradiação com diferentes doses de UVC.

O perfil normal de expressão de ctrA no ciclo celular prevê um aumento de RNAm até 90 minutos após sincronia (maioria das células em início de fase pré-divisional), seguido de queda (Domian et al., 1999). Isso está de acordo com a presença de baixos níveis da proteína no início do ciclo, para que a origem de replicação se encontre livre, e à necessidade de síntese de CtrA antes da divisão celular para que ela seja direcionada ao compartimento móvel para ali bloquear a replicação do DNA. Como podemos observar na figura 45, este perfil foi confirmado em nossos experimentos com células selvagens.

Na cepa NA1000 observamos uma aparente queda nos níveis de transcrição de ctrA após a irradiação com 15 ou $150 \mathrm{~J} / \mathrm{m}^{2}$ (Figura 45). Na dose de $15 \mathrm{~J} / \mathrm{m}^{2}$ a redução é mais significativa até 90 minutos após a sincronização celular. É observado um atraso no máximo de expressão, o que correlaciona bem com o atraso do ciclo observado por citometria de fluxo (Figura 32). Na dose de $150 \mathrm{~J} / \mathrm{m}^{2}$ observamos também que os níveis de ctrA permanecem reduzidos e aproximadamente constantes a partir de 30 minutos, o que indica que a transcrição desse gene não é ativada no ciclo, para as células irradiadas. É importante destacar que estes dados não refletem um bloqueio generalizado de transcrição, uma vez que os dados correspondem a níveis relativos de ctrA em relação ao gene CC_3130, cuja expressão não varia no ciclo (McGrath et al., 2007) e nem é induzida por luz UVC (dados não apresentados). 


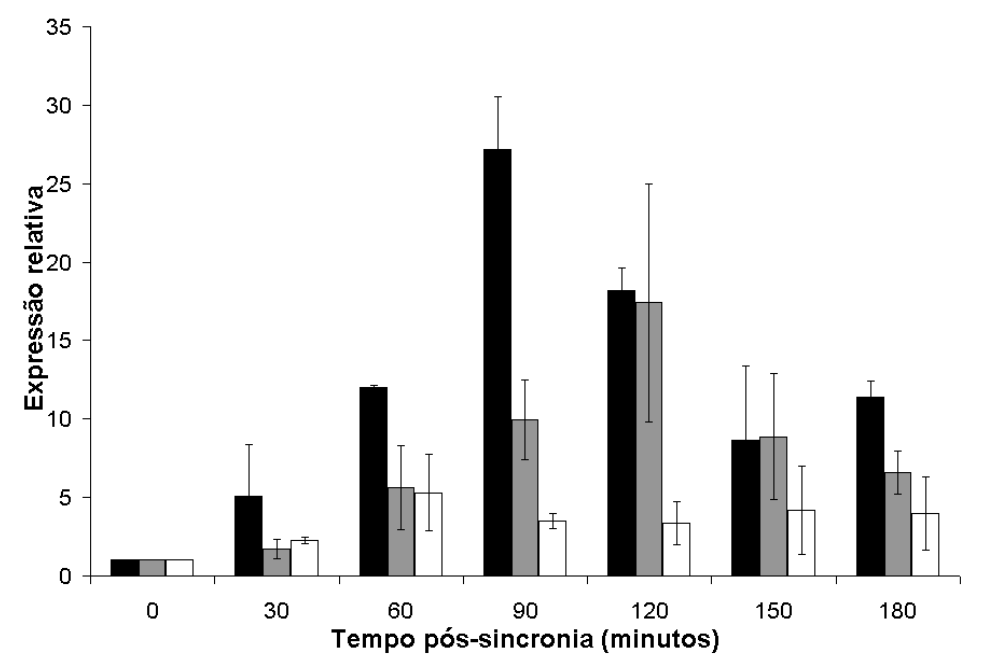

Figura 45 - Expressão do gene ctrA medida por RT-PCR quantitativo na cepa NA1000 em tempos crescentes após a sincronização e tratada ou não com luz UVC. As irradiações foram realizadas no tempo zero e os tempos após a sincronia estão indicados na figura. A figura representa médias e desvios padrões de pelo menos três experimentos diferentes. Barras pretas: NA1000 não irradiada, barras cinzas; NA1000 $15 \mathrm{~J} / \mathrm{m}^{2}$ e barras brancas: NA1000 $150 \mathrm{~J} / \mathrm{m}^{2}$.

Os níveis normais de ctrA na cepa uvrA são ligeiramente diferentes daqueles observados para NA1000 (Figura 46): os valores de expressão relativa são maiores nesta célula e ela parece se elevar até 90 minutos, apresentando redução mais lenta após 120 minutos. Dados preliminares indicam que o tempo de geração de uvrA em meio mínimo é maior do que o observado para NA1000 (dados não mostrados), e isso pode explicar esses dados de transcrição de ctrA entre 90 e 180 minutos. Os níveis deste transcrito após a irradiação sofrem uma queda mais dramática nesta cepa do que em NA1000, e eles se mantém aproximadamente constantes após 15 ou $150 \mathrm{~J} / \mathrm{m}^{2}$. É importante destacar que a regulação pós-traducional é um passo importante na regulação de CtrA (revisto por Curtis e Brun, 2010): além da transcrição, CtrA pode ser regulado por fosforilação e proteólise. Ainda nos resta, portanto, analisar como a proteína, fosforilada ou não, se comporta ao longo do ciclo. 


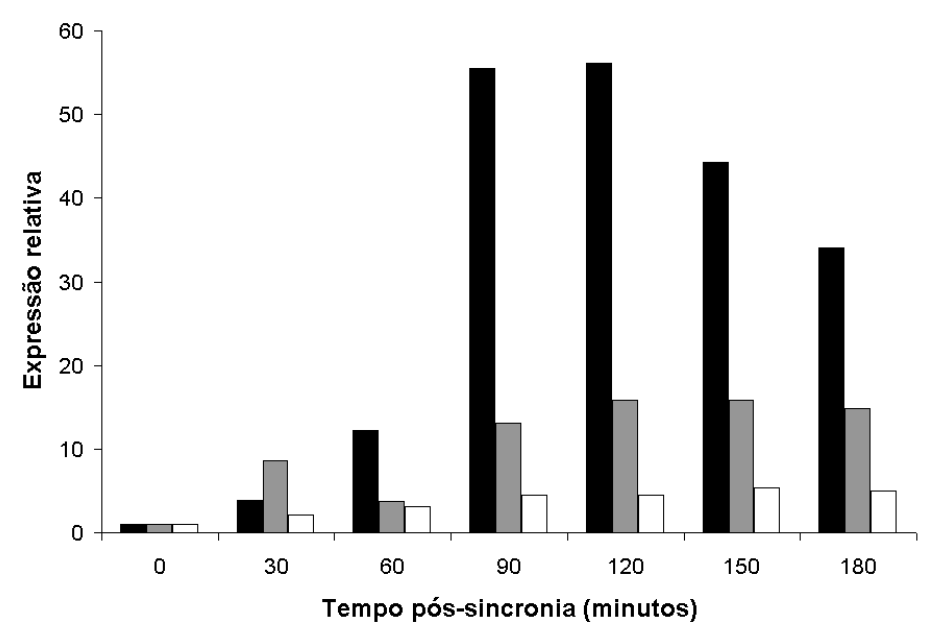

Figura 46 - Expressão do gene ctrA medida por RT-PCR quantitativo na cepa uvrA em tempos crescentes após a sincronização e tratada ou não com luz UVC. As irradiações foram realizadas no tempo zero e os tempos após a sincronia estão indicados na figura. Barras pretas: uvrA não irradiada, barras cinzas; uvrA $15 \mathrm{~J} / \mathrm{m}^{2}$ e barras brancas: uvrA $150 \mathrm{~J} / \mathrm{m}^{2}$.

C. crescentus possui, assim como a maioria dos organismos, o gene phr, que codifica uma enzima chamada fotoliase, capaz de remover os dímeros de pirimidina em uma reação dependente de luz visível e UVA (revisto por Friedberg et al., 2006). A descrição da fotoliase de $C$. crescentus demonstrou que ela é capaz de remover CPDs, mas não 6-4 PPs, sendo, portanto classificada como uma CPD-fotoliase (Öztürk et al., 2008). A presença desta proteína se mostrou então uma importante ferramenta para determinar a importância das lesões CPDs no bloqueio do ciclo celular após irradiação com luz UVC. Para tanto, inicialmente testamos a sobrevivência das cepas NA1000 e uvrA após irradiação e posterior fotorreativação.

Como podemos observar, a sobrevivência das cepas aumenta após a etapa de fotorreativação, sendo a melhora mais expressiva após fotorreativação com o comprimento de onda correspondente a UVA do que com luz visível (Figura 47). Isso está de acordo com dados da literatura que demonstram que a fotoliase de $C$. crescentus absorve comprimentos de onda na faixa entre 300 e 400 nm (Öztürk et al., 2008). 


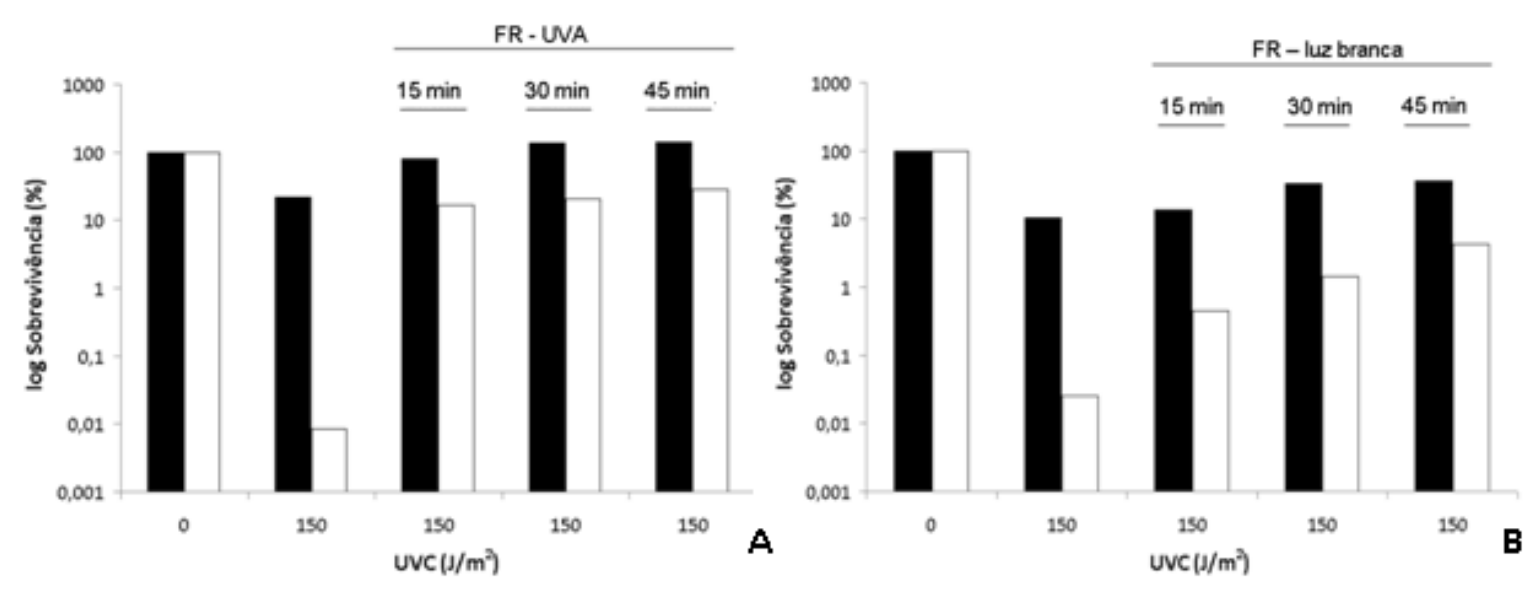

Figura 47 - Sobrevivência das cepas NA1000 e uvrA frente à irradiação com $150 \mathrm{~J} / \mathrm{m}^{2}$ de luz UVC e seqüente fotorreativação com UVA (A) ou luz branca (B). Os tempos de fotorreativação (FR) se encontram indicados na figura. Barras pretas: NA1000, barras brancas: uvrA.

Esse fato também é corroborado pela medição do número de CPDs / kbp presentes no genoma das bactérias após a fotorreativação com luz UVA ou luz visível (figura 48); apesar do reparo de CPDs na cepa NA1000 ser eficiente também na luz visível (compare as figura 48 A e C), observamos a maior eficiência da luz UVA em promover fotorreativação com mais clareza na cepa uvrA, que possui deficiência em uma das vias responsáveis por remover lesões causadas por UVC (compare as figuras 48 B e D). Por esse motivo, decidimos prosseguir com os experimentos de fotorreativação utilizando luz UVA durante 15 minutos. 
NA1000
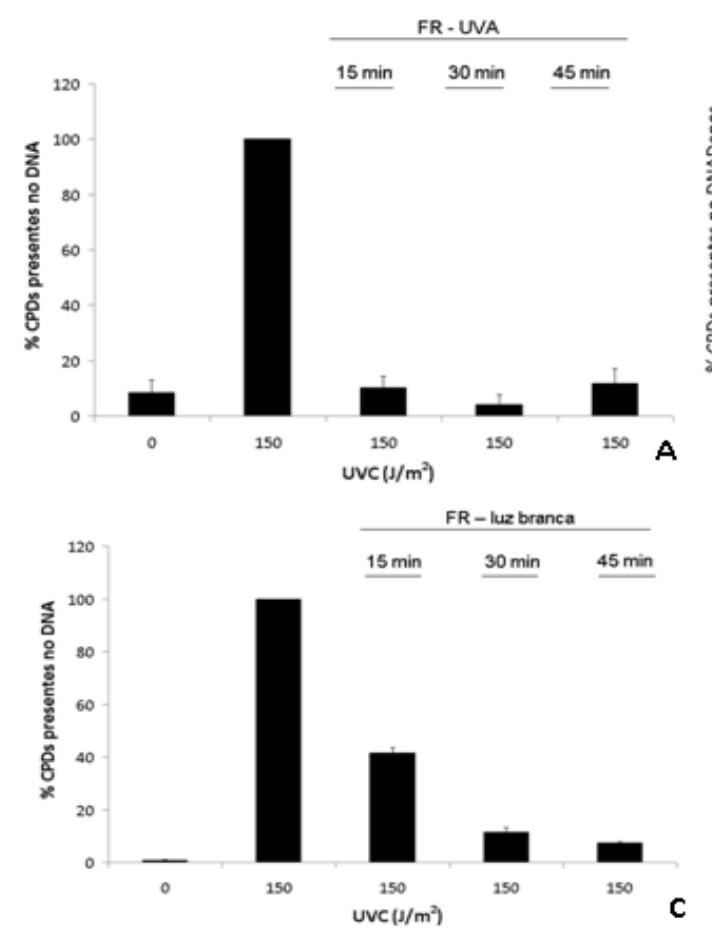

uvrA
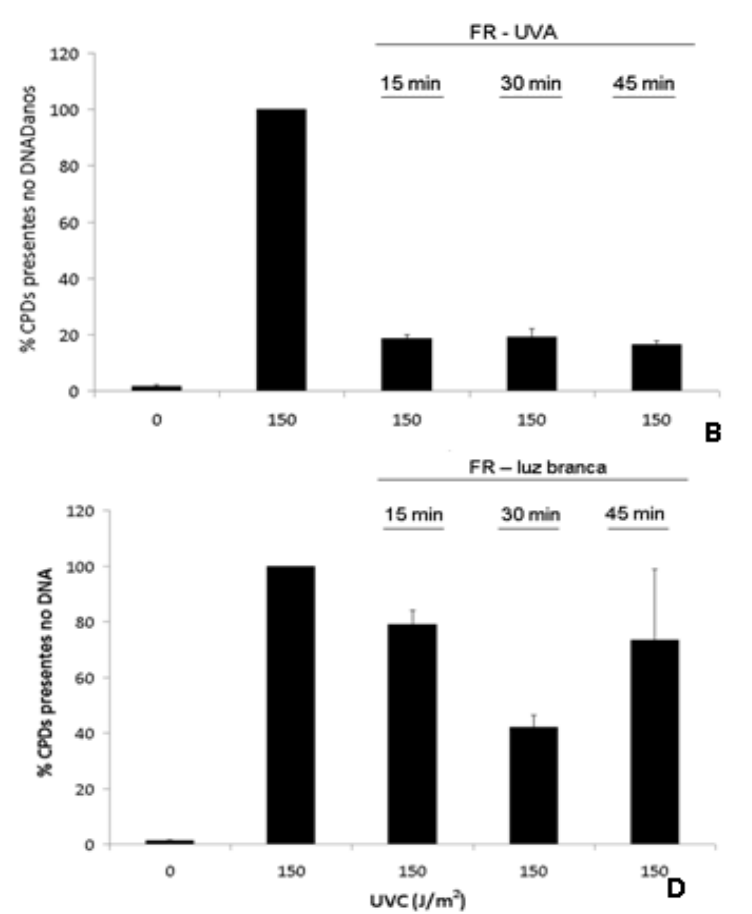

Figura 48 - Quantificação das lesões CPDs no DNA genômico de NA1000 e uvrA irradiadas com $150 \mathrm{~J} / \mathrm{m}^{2}$ de luz UVC e fotorreativadas com luz UVA ou luz branca. Os tempos de fotorreativação se encontram explicitados na figura. Quantificação das lesões CPDs em NA1000 ( $A$ e C C e uvrA ( $B$ e D) após a irradiação e fotorreativação (FR) com luz UVA ou branca a partir dos resultados obtidos com marcação por anticorpo anti-CPD.

Essa estratégia de remoção de lesões por fotorreativação foi empregada para estudar os efeitos da luz UVC no ciclo de C. crescentus. Quando comparamos os perfis do conteúdo de DNA obtidos por citometria de fluxo nas cepas NA1000 e uvrA irradiadas com $150 \mathrm{~J} / \mathrm{m}^{2}$ de UVC e fotorreativadas, podemos observar que a remoção de CPDs não promove recuperação do ciclo celular pelo menos após três horas do processo de sincronização e irradiação em ambas cepas (Figuras 49 e 50). Para a cepa uvrA é possível que a remoção das lesões não seja suficiente para observarmos qualquer efeito (pois $10 \%$ das lesões são suficientes para bloquear o ciclo, ver figura 33). Por outro lado, os dados com NA1000 são curiosos, pois esperávamos uma recuperação da capacidade celular de progredir no ciclo, da mesma forma que observamos recuperação na sobrevivência celular. É possível que as lesões iniciais sejam suficientes para ativar um mecanismo de bloqueio do ciclo celular. 
0

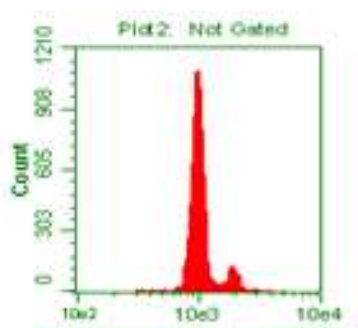

1004
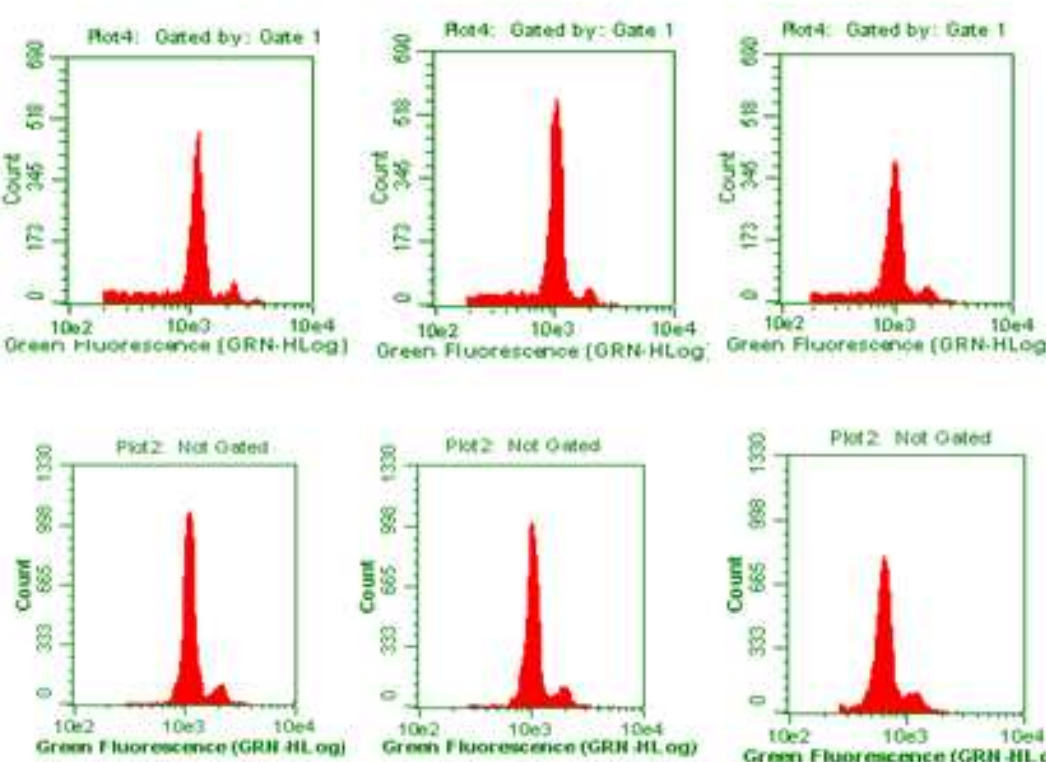

60
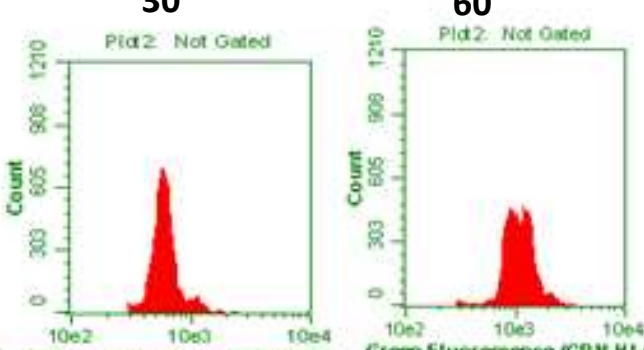

Groen fluarencence paRH-HLoos

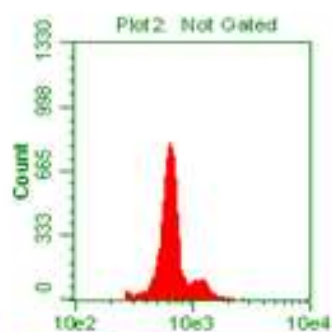

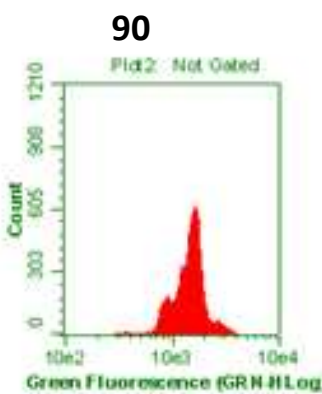
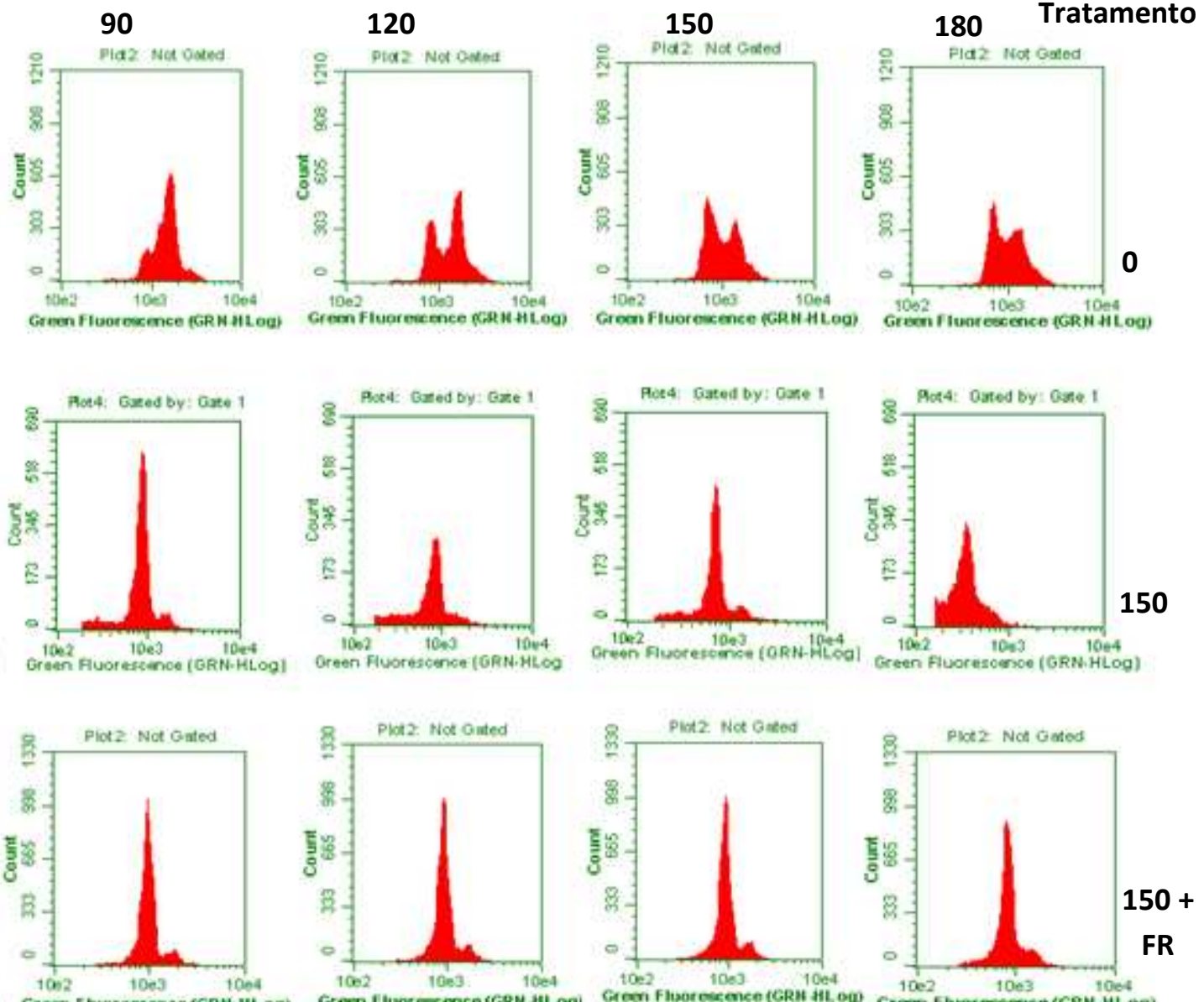

Figura 49 -

Exemplos demonstrativos do perfil de progressão do ciclo celular da cepa NA1000 sincronizada, irradiada ou não com luz UVC e fotorreativada ou não. A irradiação foi realizada no tempo zero após a sincronização e amostras foram coletadas em tempos crescentes após a sincronização celular; os tempos após a sincronização estão indicados na figura. As células foram tratadas com $0 \mathrm{~J} / \mathrm{m}^{2}, 150 \mathrm{~J} / \mathrm{m}^{0}$ sem fotorreativação e $150 \mathrm{~J} / \mathrm{m}^{2}$ e fotorreativação com luz UVA por 15 minutos (FR). Eixo das ordenadas: contagem de células, eixo das abscissas: fluorescência verde (escala logarítmica), que indica a quantidade de DNA por célula. 


\section{Tempo}

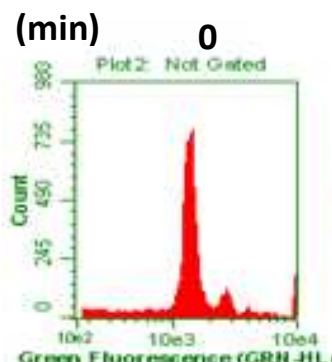

30

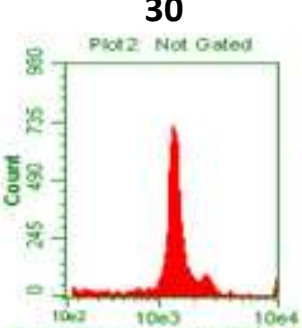

60
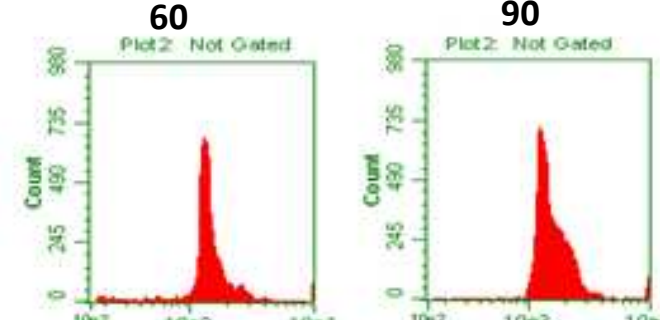

120
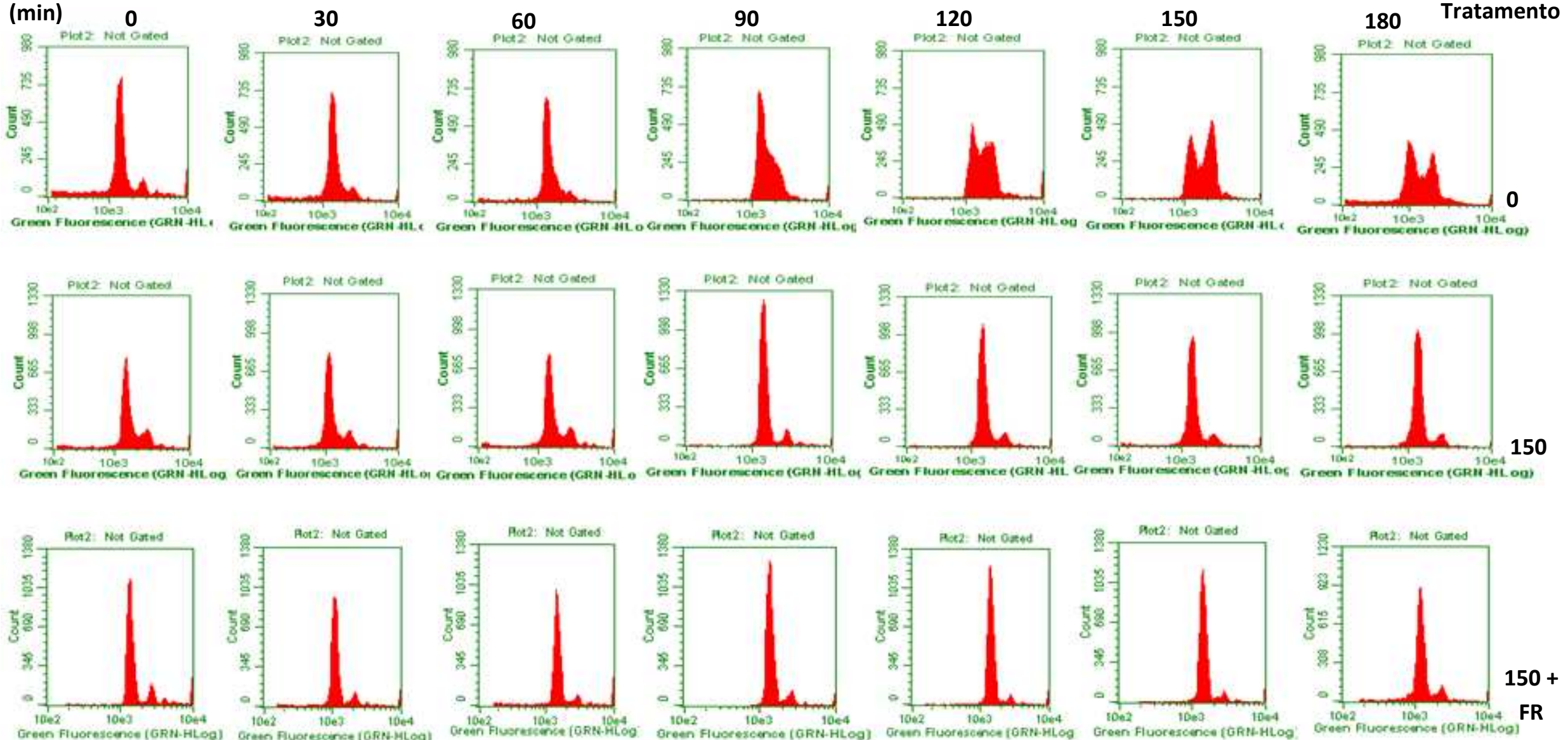

Figura 50 - Exemplos demonstrativos do perfil de progressão do ciclo celular da cepa uvrA sincronizada, irradiada ou não com luz UVC e fotorreativada ou não. A irradiação foi realizada no tempo zero após a sincronização e amostras foram coletadas em tempos crescentes após a sincronização celular; os tempos após a sincronização estão indicados na figura. As células foram tratadas com $0 \mathrm{~J} / \mathrm{m}^{2}, 150 \mathrm{~J} / \mathrm{m}^{0}$ sem fotorreativação e $150 \mathrm{~J} / \mathrm{m}^{2}$ e fotorreativação com luz UVA por 15 minutos (FR). Eixo das ordenadas: contagem de células, eixo das abscissas: fluorescência verde (escala logarítmica), que indica a quantidade de DNA por célula. 
A análise dos níveis de ctrA em NA100 após a fotorreativação indica uma discreta elevação na síntese deste após a remoção de CPDs, mas não o retorno ao perfil observado para a bactéria não irradiada no tempo estudado (Figura 51).

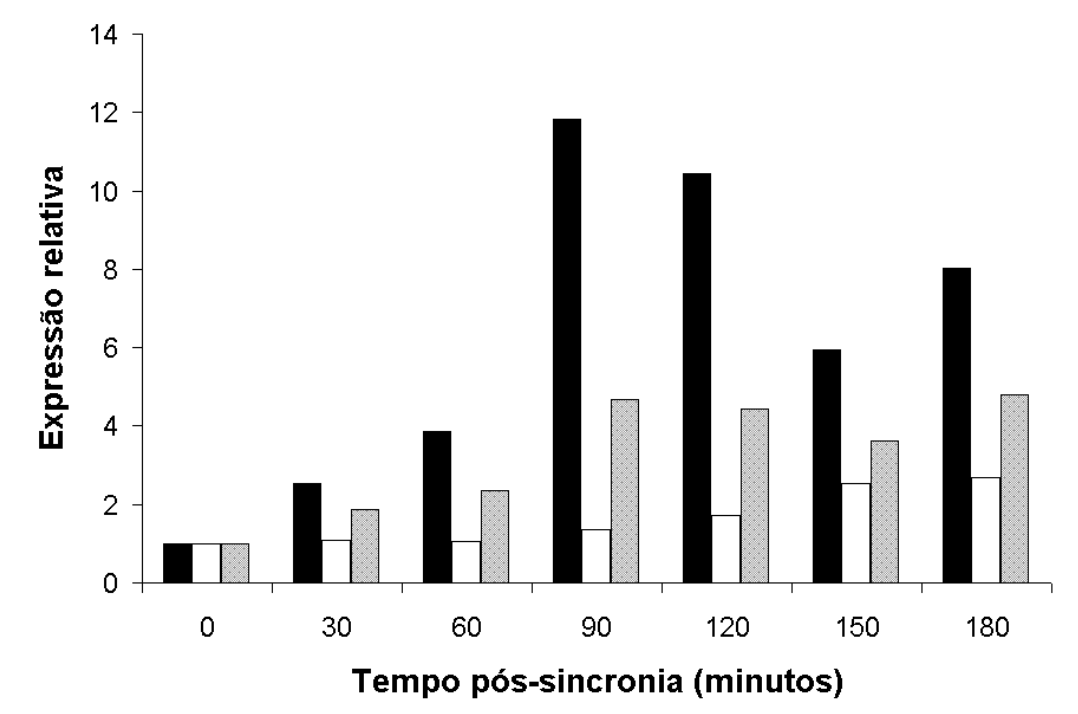

Figura 51 - Expressão do gene ctrA medida por RT-PCR quantitativo na cepa NA1000 em tempos crescentes após a sincronização, tratamento ou não com luz UVC e fotorreativação ou não com luz UVA. Aas irradiação e a fotorreativação foram realizadas no tempo zero e os tempos após a sincronia estão indicados na figura. Barras pretas: NA1000 não irradiada, barras cinzas; NA1000 $150 \mathrm{~J} / \mathrm{m}^{2}$ UVC e barras brancas: NA1000 $150 \mathrm{~J} / \mathrm{m}^{2}$ e fotorreativação com 15 minutos de UVA.

Estamos estudando em mais detalhes os efeitos da fotorreativação na progressão do ciclo celular e nos níveis de transcrição de ctrA nas cepas em questão de $C$. crescentus. Além disso, não investigamos o papel da segunda lesão mais importante gerada pela irradiação com luz UVC, os 6-4 PPs, e tampouco os níveis da proteína CtrA e suas modificações póstraducionais. Estes experimentos estão entre os nossos próximos objetivos. 


\section{DISCUSSÃO}

C. crescentus é uma bactéria notável. A facilidade de cultivo e manipulação genética a tornou um dos grandes modelos no que se refere a estudos fisiológicos e genéticos em procariontes. A compreensão de como este organismo de vida livre interage com o ambiente ao seu redor trouxe novos e importantes conhecimentos para o campo da microbiologia. A maioria dos estudos realizados até agora se focaram na busca da compreensão de como C. crescentus coordena os eventos complexos de seu ciclo e como esses dados podem ser extrapolados para outros organismos. Poucos trabalhos analisaram os mecanismos de reparo de DNA neste organismo (Bender, 1984; Colombi e Gomes, 1997; Galhardo et al., 2005; Martins-Pinheiro et al., 2007) e não existem registros em literatura que relacionem a existência destes com a progressão do ciclo celular nesta bactéria. Como outras bactérias, como E. coli, não são propícias para estudos de ciclo celular, o conhecimento das correlações entre danos ao DNA, reparo e ciclo celular em bactérias é, ao contrário de células de mamíferos, pobre. Neste contexto, nosso trabalho ajuda a estabelecer ferramentas de análise e bases de conhecimentos para futuras explorações nessa área de pesquisa.

Nosso laboratório participa ativamente da elucidação dos mecanismos de reparo de C. crescentus. Dentro deste objetivo maior, podem ser destacados três trabalhos. O primeiro demonstrou que o operon composto pelos genes $i m u A$, imuB e por uma segunda cópia da DNA polimerase replicativa (dnaE2) é responsável pela mutagênese induzida pela irradiação com luz UV (Galhardo et al., 2005). Este papel é realizado em E. coli pelo operon composto por umuDC; estes genes estão restritos apenas a bactérias filogeneticamente próximas a $E$. coli, enquanto o operon descrito por nosso grupo é muito mais amplamente distribuído (presente em outras proteobactérias, como Sinorhizobium meliloti, Bdellovibrio bacteriovorus e Psedomonas aeruginosa, além de $M$. tuberculosis) (Tabela 10). Dentre os trabalhos ainda não publicados, é importante destacar aqueles realizados pela Dra. Marinalva Martins-Pinheiro e pela Dra. Regina Célia Pereira Marques. Através da seleção de uma biblioteca de 5.000 clones de $C$. crescentus contendo inserção aleatória do transpóson Tn5 (gentilmente cedida pela Prof. Dra. Marilis do Valle Marques), a Dra. Marinalva identificou clones com alteração da frequência de mutação espontânea, determinada pela 
análise do gene $r p o B$. Além disso, ela também realizou uma importante busca in silico no genoma de $C$. crescentus de genes de reparo presentes em outras bactérias, trabalho este já publicado (Martins-Pinheiro et al., 2007). A Dra. Regina buscou na mesma biblioteca descrita acima clones sensíveis a diversos agente genotóxicos, como luz UVB e MMS; dessa forma ela identificou cerca de 100 genes potencialmente envolvidos nas respostas de $C$. crescentus a injúrias ao material genético.

Dentro do esforço de nosso laboratório em caracterizar as vias de reparo de DNA, nosso primeiro objetivo foi a elucidação da resposta SOS de C. crescentus. Esta resposta ampla a danos ao DNA capazes de bloquear a progressão da polimerase replicativa foi inicialmente estudada em E. coli e a maioria dos dados hoje disponíveis se referem a este organismo (Courcelle et al., 2001; Khill e Camerini-Otero, 2002; Quillardet et al., 2003). A determinação do regulon em outros organismos (Cirz et al., 2007; Au et al., 2005; Erill et al., 2003; Erill et al., 2004; Campoy et al., 2005) nos levou, no entanto, a questionar a universalidade dos genes regulados por LexA em E. coli. Para tanto, construímos um mutante deficiente para o gene lexA, o repressor do regulon; a comparação da expressão dos genes identificados in silico nas cepas selvagem e lexA permitiu o estabelecimento dos genes pertencentes ao regulon SOS em C. crescentus. Além disto, confirmamos o motivo de ligação de LexA ao DNA em C. crescentus como sendo similar ao descrito anteriormente para as proteobactérias alfa (Erill et al., 2004) e também validamos in vivo esta seqüência pelo mapeamento do início de transcrição de dois genes pertencentes ao regulon (imuA e CC_2272) e pela mutagênese do promotor de imuA, substituindo duas bases importantes para a associação de LexA.

Em relação ao conjunto de genes regulados por LexA, confirmamos a regulação daqueles que são sempre reprimidos nas proteobactérias alfa: $\operatorname{rec} A$, lex $A, s s b, \operatorname{uvr} A$ e $\operatorname{ruv} C A B$ (Erill et al., 2004). O gene mais induzido do regulon foi lexA, seguido de uma JAL hipotética, CC_0627. Para melhor visualizarmos as diferenças entre os genes regulados por LexA em diferentes bactérias, elaboramos uma tabela comparativa. Nesta tabela listamos os principais genes identificados como parte do regulon em $C$. crescentus, além de outros genes identificados em E. coli, mas que não foram confirmados neste trabalho. 
Tabela 10 - Análise comparativa dos genes pertencentes ao regulon SOS. Somente bactérias com genomas completamente sequenciados estão listadas.

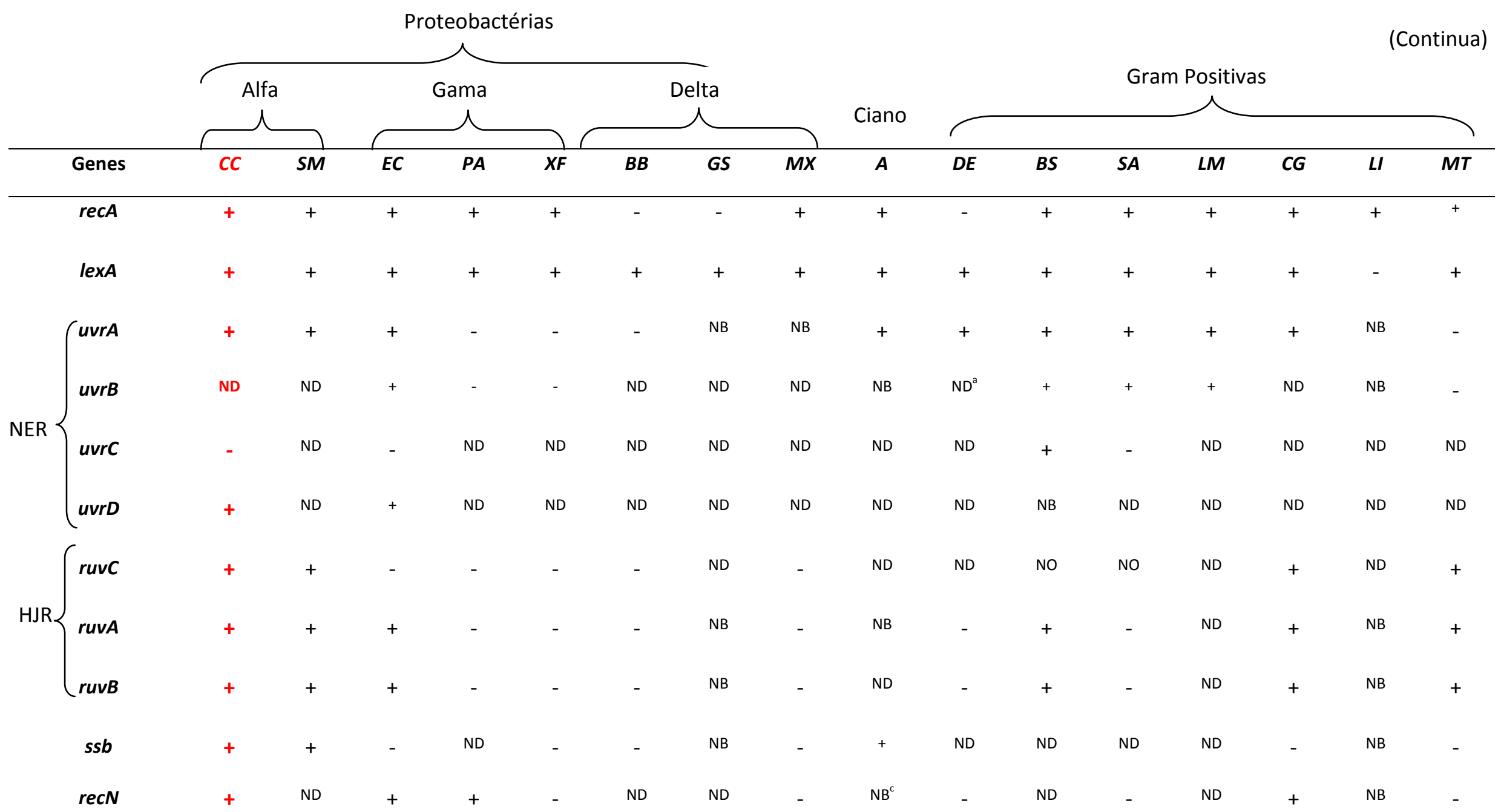


Tabela 10 - Análise comparativa dos genes pertencentes ao regulon SOS. Somente bactérias com genomas completamente sequenciados estão listadas.

(Continuação)

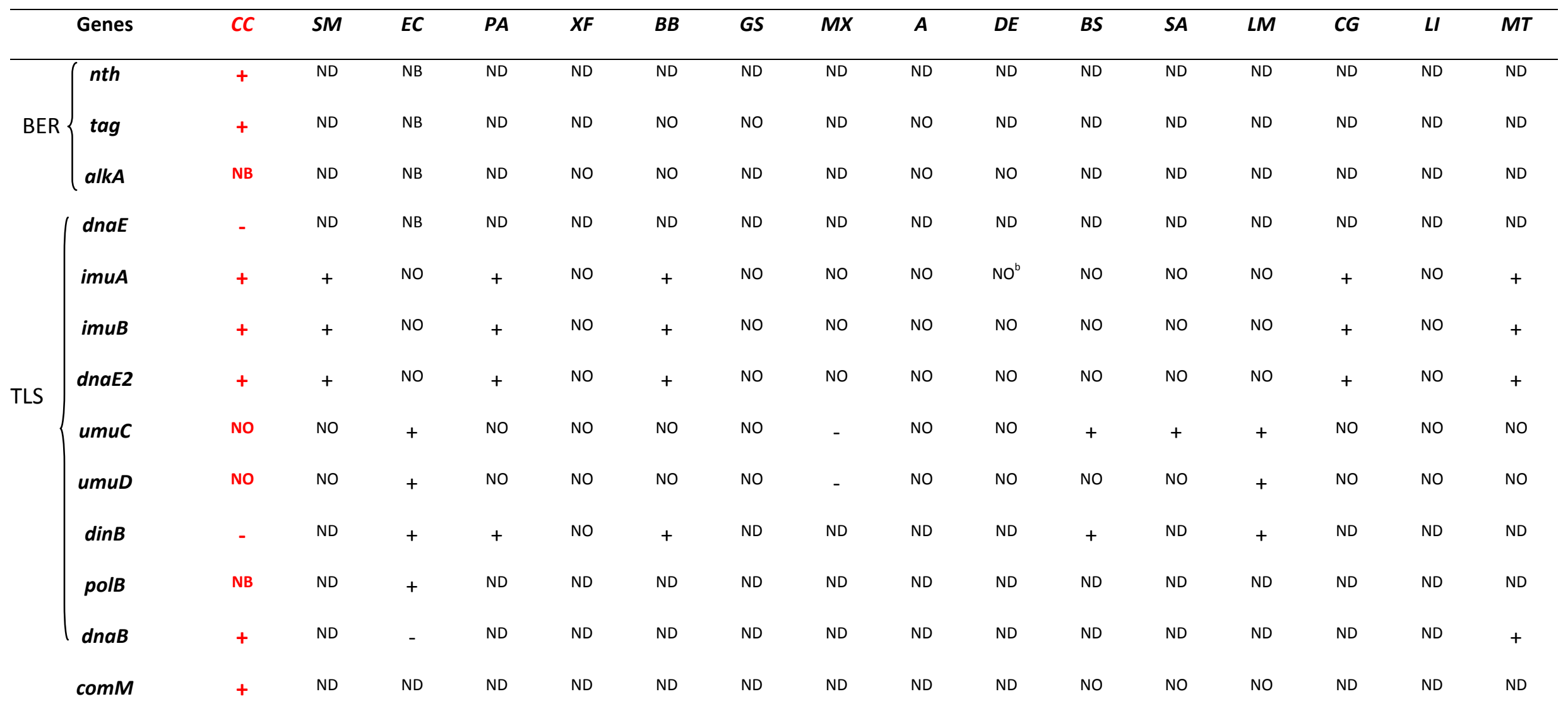


Tabela 10 -

Análise comparativa dos genes pertencentes ao regulon SOS. Somente bactérias com genomas completamente sequenciados estão listadas.

(Conclusão)

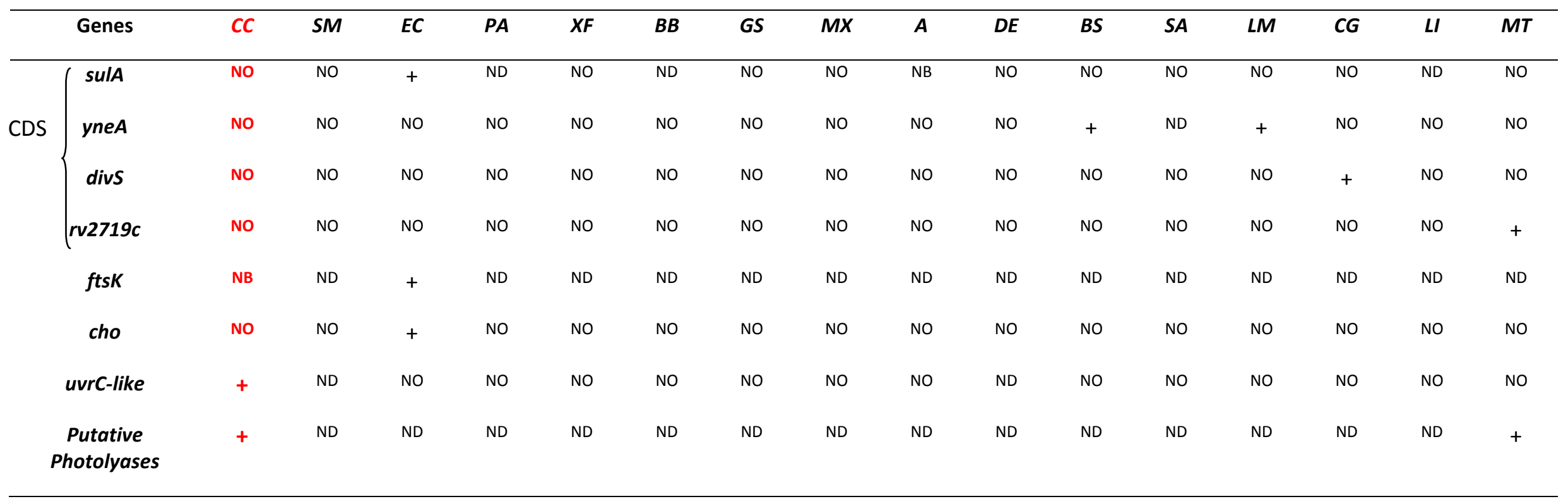

Os símbolos de mais (+) e menos (-) indicam que o gene é ou não é regulado por LexA, respectivamente; ND indica que o gene existe na bactéria, mas não existem dados na literatura sobre sua regulação; NO indica que ortólogos deste gene não estão presentes no genoma da bactéria; NB indica que o gene existe na bactéria, mas análises in silico indicaram que ele não possui um operador SOS em sua região promotora. NER: reparo por excisão de nucleotídeos, HJR: Resolvases de Junção de Holliday, BER: reparo por excisão de bases; TLS: síntese translesão; CDS: supressor da divisão celular.

As abreviações dos nomes dos organismos são: CC, Caulobacter crescentus; SM, Sinorhizobium meliloti; EC, E. coli; PA, Pseudomonas aeruginosa; XF, Xylella fastidiosa; BD, Bdellovibrio bacteriovorus; GS, Geobacter sulfurreducens; MX, Myxococcus xanthus; A, Anabaena sp.; DE, Dehalococcoides ethenogenes; BS, Bacillus subtilis; SA, Staphylococcus aureus; LM, Listeria monocytogenesis; CG, Corynebacterium glutamicum; LI, Leptospira interrogans; MT, Mycobacterium tuberculosis (Rivera et al., 1996; Rivera et al., 1997; Tapiás e Barbe, 1999; Fernandez de Henestrosa et al., 2000; Brooks et al., 2001; Courcelle et al., 2001; Campoy et al., 2002; Davis et al., 2002; Fernandez de Henestrosa et al., 2002; Khill e Cameirin-Otero, 2002; Campoy et al., 2003; Jara et al., 2003; Kawai et al., 2003; Quillardet et al., 2003; Sung et al.,2003; Erill et al., 2004; Mazon et al., 2004; Au et al., 2005, Campoy et al., 2005; Cuñe et al., 2005; Cirz et al., 2006; Cirz et al., 2007, Jochman et al., 2009; van der Veen et al., 2010) 
A tabela indica grande variedade do conjunto de genes regulados por LexA, dependendo do organismo que está sendo analisado. Os dois genes que parecem ser parte do regulon na maioria dos casos são recA e lexA, os reguladores do sistema. A regulação dos demais genes identificados em $C$. crescentus não pode ser confirmada em outros organismos, nem mesmo aqueles descritos acima como sendo sempre regulados por LexA em proteobactérias. Os dados apresentados na tabela 10 também reforçam a ideia de que os genes que são parte do regulon em E. coli não podem ser considerados como modelo para outros organismos. A resposta SOS é uma via coordenada de resposta a danos ao DNA em bactérias, mas variações individuais são importantes e não devem ser menosprezadas.

Dentre os genes interessantes pertencentes ao regulon SOS, podemos destacar inicialmente aqueles envolvidos na via de reparo por excisão de bases (BER). Desconhecemos dados de literatura que façam referencia a estes genes como regulados por LexA, mas nosso trabalho mostrou que três glicosilases de DNA são parte do regulon: $\operatorname{tagA}$, que codifica a 3metiladenina glicosilase I; CC_2333 que é relacionada a uracila DNA glicosilase; e CC_2272, que codifica uma proteína da família das endonucleases III (Martins-Pinheiro et al., 2007). Em E. coli a 3-metiladenina glicosilase I é uma proteína induzida por danos oxidativos (Metz et al., 2007), e os dados que indicam sua regulação por LexA em $C$. crescentus são curiosos, uma vez que as células bacterianas possuem, em geral, duas 3-metiladeninas glicosilases: a codificada pelo gene alkA (CC_2201) é induzida por doses subletais de agentes alquilantes, enquanto tagA é expresso constitutivamente (Bjelland e Seeberg, 1996). A indução de tagA como parte da resposta SOS pode indicar que danos por agentes alquilantes são muito importantes para $C$. crescentus em resposta a problemas encontrados em seu ambiente.

O caso de CC_2272 também é interessante e foi estudado com mais detalhes. $C$. crescentus possui duas proteínas da família das endonucleases III não relacionadas filogeneticamente que são codificadas pelos genes CC_2272 e CC_3731. O primeiro se mostrou regulado por LexA, enquanto o segundo não. Mutantes individuais para estes genes não se mostraram mais sensíveis ao tratamento com $\mathrm{H}_{2} \mathrm{O}_{2}$ ou luz UVC, similar ao fenótipo do mutante para o gene ortólogo nth de E. coli (Cunningham e Weiss, 1985). Contrariando o observado para E. coli (Cunningham e Weiss, 1985), os mutantes não apresentaram freqüência de mutação 
espontânea significativamente alterada. Em E. coli, a função do produto de $n$th pode ser realizada também pelo produto de gene nei, a endonuclease VIII (Saito et al., 1997), de modo que o duplo mutante nth nei é muito sensível ao tratamento com $\mathrm{H}_{2} \mathrm{O}_{2}$. C. crescentus não possui ortólogos de nei, e por isso, nossa hipótese era de que uma das endonucleases III poderia compensar a falta da outra e vice-versa. Quando construímos o mutante duplo deficiente em CC_2272 e CC_3731, percebemos que não era esse o caso. Este duplo mutante não mostrou maior sensibilidade ao tratamento com $\mathrm{H}_{2} \mathrm{O}_{2}$ quando comparado com os mutantes individuais ou com a bactéria selvagem. Os genes de BER são tradicionalmente conhecidos pela grande sobreposição de função, o que em muitos casos dificulta a análise do fenótipo de mutantes de genes individuais. $C$. crescentus ainda apresenta dois genes que codificam proteínas anotadas como Xth (exodeoxirribonuclease III) (Martins-Pinheiro et al., 2007), que é envolvida com reparo de lesões oxidativas em $E$. coli, sendo responsável pela maioria da atividade de APendonuclease observada neste organismo. Dessa forma, uma dessas proteínas pode compensar a deficiência desses mutantes, garantindo a resistência ao tratamento com $\mathrm{H}_{2} \mathrm{O}_{2}$. Esta ainda é uma possibilidade que precisa ser estudada.

No que se refere ao reparo por excisão de nucleotídeos observamos a regulação de uvrA e $u v r D$ como em E. coli, mas uvrB não possui um operador SOS em sua região promotora, contrariando o observado nesse organismo (Courcelle et al., 2001). O gene CC_3518, regulado por LexA, é outro caso interessante. Ele codifica uma proteína com alta similaridade a região Nterminal da endonuclease UvrC. E. coli codifica uma proteína semelhante, também regulada por LexA e denominada Cho (Moolenar et al., 2002), mas esta é distinta daquela codificada por CC_3518, denominada de uvrC-like endonuclease (Martins-Pinheiro et al., 2007). O papel sugerido de Cho é atuar em conjunto com o NER em lesões muito distorcivas e de difícil acesso para UvrC (Van Houten et al., 2002). Uma breve análise de blast (dados não apresentados) revelou que homólogos de CC_3518 estão mais distribuídos nos genomas bacterianos do que Cho, o que sugere sua importância para as bactérias.

Outro grupo de genes que nos chamou muita atenção foi aquele dos pertencentes aos sistemas de toxinas-antitoxinas. Cinco genes identificados como parte do regulon SOS fazem parte deste grupo (CC_1054, CC_2879 e CC_2880, CC_3037 e CC_3038). Estes sistemas foram 
inicialmente descobertos em plasmídeos como parte da estratégia destes para evitar a proliferação de células que eventualmente perdessem o plasmídeo (revisto por Gerdes et al., 2005). Sua presença foi descrita em um grande número de genomas de bactérias de vida livre, e vários sistemas são observados (Pandey e Gerdes, 2005). Sua função nos sistemas bacterianos ainda é motivo de grande debate, sendo que uma das possibilidades é de que atuem na resposta geral a estresses (Buts et al., 2005). Existem alguns trabalhos que questionam esta visão (Tsilibaris et al., 2007) e nosso trabalho vai de encontro a estes. Um mutante para o possível operon codificado por CC_3038-CC_3037-CC_3036 foi construído neste trabalho, antes que percebêssemos que CC_3037 e CC_3038 eram parte do sistema de toxina-antitoxina higBA (Pandey e Gerdes, 2005). A análise do fenótipo deste mutante não revelou quaisquer alterações morfológicas, de crescimento, viabilidade ou sensibilidade a irradiação com luz UVC e $\mathrm{H}_{2} \mathrm{O}_{2}$ (dados não mostrados). A função destes genes para a fisiologia de $C$. crescentus ainda permanece desconhecida.

Alguns outros genes interessantes foram identificados. CC_0140, por exemplo, codifica a proteína comM, uma ATPase similar aquela presente em algumas quelatases de magnésio; ela pode estar envolvida na regulação da fidelidade de polimerases durante a resposta SOS, com foi proposto para membros desta classe de proteínas em E. coli (Yang et al., 2004). Os produtos dos genes CC_1330 e CC_2332 pertencem a superfamília de radicais SAM (S-adenosilmetionina), que engloba também a fotoliase de fotoprodutos de esporos de B. subtilis ( $s p / B$, Nicholson et al., 1997). Foi demonstrado que um homólogo destes genes em M. tuberculosis é parte do regulon SOS dessa bactéria (Davis et al., 2002), reforçando um possível papel destes genes para a resposta a danos ao DNA. CC_3225, por sua vez, codifica uma histidina quinase híbrida, que é parte do sistema de dois componentes de transdução de sinal em procariontes. Este é o sistema mais empregado para a transmissão de informações intra e extracelulares em procariontes, sendo responsável por desencadear respostas aos mais diversos estímulos como deficiência de fosfato, transformação, anaerobiose, virulência e progressão do ciclo celular (revisto por Pirrung, 1999). Em C. crescentus, os sistemas de dois componentes são essenciais para a manutenção da assimetria e para a correta progressão do ciclo celular, como podemos observar pela essencialidade do regulador de resposta CtrA (Quon et al., 1996). A existência, portanto, de 
uma histidina quinase hibrida como parte do regulon SOS adiciona mais um nível de complexidade a ele: apesar de não sabermos seu substrato ou o destino final de sua cadeia de transferências de fosfatos, esta proteína deve ser responsável pela regulação de um ou vários genes. A deleção sistemática das histidinas quinases / reguladores de resposta de $C$. crescentus foi realizada (Skerker et al., 2005), e obtivemos uma cepa mutante para o gene CC_3225, gentilmente cedida pelo Dr. Michael Laub, do grupo que realizou este trabalho. Ela não mostrou quaisquer alterações significativas morfológicas, de crescimento, viabilidade ou sensibilidade a irradiação com luz UVC. Desta forma, não podemos oferecer mais detalhes a cerca de seu papel na resposta de $C$. crescentus a danos ao DNA. Entretanto, recentemente verificamos que os níveis dos RNAs dos genes CC_2433 e dnaB são nitidamente alterados nesse mutante. Estes dados sugerem uma interface na regulação controlada (direta ou indiretamente) por esse quinase e o regulon SOS. Essa interface merece ser melhor investigada.

Nossa análise nos demonstrou que grande parte dos genes identificados não possui função conhecida, sendo que alguns deles sequer possuem similaridades com outras proteínas dos genomas microbiais seqüenciados até a agora. Este é o caso do gene CC_0627, que codifica uma proteína hipotética, e está possivelmente em operon com as JALS CC_0625 e CC-0624, duas transposases. Este é o segundo gene mais induzido na ausência de lexA, e a curiosidade nos levou a construir uma cepa mutante para este gene. A análise microscópica desta não revelou alterações significativas, mas sua sobrevivência frente à luz UVC é significativamente menor do que a das cepas NA1000 e lexA. Isso indica que CC_0627 (ou até mesmo todo o seu operon, que não foi estudado) é importante para a resposta da célula a este agente.

Chamou-nos a atenção os níveis de indução dos genes CC_2433 e dnaB, a DNA helicase replicativa. Estes parecem ser induzidos por LexA, uma vez que sua expressão é drasticamente reduzida na ausência desta. Foram encontradas na literatura três referências a um comportamento semelhante de LexA em outros organismos. Em R. sphaeroides, LexA é capaz de reprimir ou estimular a transcrição de $r e c A$, dependendo de sua concentração protéica (Tapias et al., 2002). Na bactéria Gram positiva C. glutamicum, LexA parece ser capaz de induzir a expressão de pelo menos dois genes envolvidos em transporte e na biossíntese de vitamina $B_{6}$ (Jochmann et al., 2009). Já na cianobactéria Synechocystis, LexA parece induzir a expressão do 
operon hox, que codifica uma hidrogenase de níquel e ferro (Gutekunst et al., 2005); aqui este fato não é surpreendente, pois já foi demonstrado que o gene lexA de algumas cianobactérias foi co-optado para a regulação de outras funções que não a resposta a injúrias ao DNA (Li et al., 2010). A repressão de $d n a B$ na ausência de LexA pode ser explicada talvez como um mecanismo da célula para evitar ou diminuir o ritmo da replicação do DNA, até que as lesões tenham sido removidas. Isso poderia representar um checkpoint associando danos ao DNA a replicação deste. Neste sentido é interessante notar que a expressão de dnaB sofre uma redução ainda mais drástica no mutante para CC_3225, o que pode indicar que esta quinase esteja envolvida na via que leva a repressão de $d n a B$ após injúrias ao material genético. Já foi demonstrado que em E. coli, DnaB está envolvida na reativação da forquilha de replicação após o bloqueio desta por lesões (que, por sinal, também é o sinal indutor do regulon SOS) (Heller e Marians, 2006). Estes fatos apresentam implicações diretas para os possíveis mecanismos de checkpoints presentes em $C$. crescentus que serão discutidos a seguir.

O caso de CC_2433 é mais difícil de ser analisado, uma vez que este codifica uma proteína hipotética e apresenta expressão reduzida nos mutantes lexA e CC_3225. Para descobrir qual o seu papel para a resposta sOS de $C$. crescentus, tentamos construir um mutante nulo para este gene. Até o momento da conclusão deste trabalho não foi possível a obtenção desse mutante, o que pode indicar que este gene seja essencial. No entanto, mais estudos são necessários para nos certificarmos deste fato.

O mutante lexA de $C$. crescentus é viável, mas apresenta severas deficiências de crescimento e viabilidade e sua análise microscópica revelou células de aspecto filamentoso. Em E. coli, o gene responsável pelo bloqueio da divisão celular mediado por SOS é sulA; como já foi dito, ele exerce este papel por bloquear a polimerização do anel de FtsZ no septo divisional. $C$. crescentus não possui homólogos de sulA; $B$. subtilis e $C$. glutamicum também não possuem, mas nestes organismos existem outros genes responsáveis pelo mesmo fenômeno (Kawai et al., 2003; Ogino et al., 2007), cujos ortólogos também não estão presentes no genoma de $C$. crescentus. Tentamos determinar qual gene poderia desempenhar o papel de sulA em $C$. crescentus, através de diversas estratégias diferentes. Construímos duplos mutantes de lexA e outros genes pertencentes ao regulon SOS (CC_3225, CC_0627 e o operon CC_3038-CC_3037- 
CC_3036), sendo que, em nenhum destes casos, o fenótipo filamentoso foi revertido. Decidimos então realizar mutagênese aleatória de lexA, selecionando clones que revertessem do fenótipo não nadador de lexA para o nadador da cepa selvagem NA1000, provando, portanto a inativação do gene responsável pela filamentação em lexA. Mais de 7.000 clones foram analisados, e nenhum deles demonstrou a reversão esperada do fenótipo. Dados de citometria de fluxo obtidos neste trabalho mostraram que a cepa lexA apresenta vários genomas por célula, o que indica que o bloqueio da divisão celular que ocorre nesta não é dependente de bloqueios na síntese de DNA. O mecanismo que causa o impedimento da divisão celular em lexA pode ser dependente da maquinaria de divisão em si, mas isso ainda não pode ser confirmado.

Nosso interesse na existência de mecanismos de checkpoints em bactérias acoplando a existência de danos ao DNA com a progressão do ciclo celular foi explorado com o estabelecimento de duas técnicas importantes em nosso laboratório: a sincronização celular de C. crescentus e análise do conteúdo de DNA através da citometria de fluxo. Como já foi dito, a sincronização permite a obtenção de células móveis em fase G1, que podemos acompanhar então, por um ciclo de divisão celular. Para entender como o ciclo celular de $C$. crescentus se comporta frente a danos ao DNA (exemplificados aqui pelos danos induzidos pela luz UVC, que são principalmente os dímeros de pirimidina ciclobutanos, CPDs), submetemos cepas deficientes nas vias de reparo por excisão de nucleotídeos ( $u v r A$, $u v r B$ e $u v r C$ ) e síntese translesão (imuA e dnaE2) à sincronização celular, seguida da irradiação com luz UVC e análise do perfil de DNA pela incorporação de uma substância fluorescente intercalante da molécula. Como esperado, doses altas de luz UVC (90 e $150 \mathrm{~J} / \mathrm{m}^{2}$ ) são capazes de induzir parada no ciclo celular de todas as células analisadas, aparentemente na fase pré-sintética G1. As cepas deficientes em NER se mostraram mais sensíveis à irradiação com UVC, e por isso a parada no ciclo celular nestes mutantes ocorre em uma dose muito menor $\left(15 \mathrm{~J} / \mathrm{m}^{2}\right)$.

Foi demonstrado em células de mamíferos que as lesões CPDs são as maiores responsáveis pelos efeitos deletérios da luz UV (Lima-Bessa et al., 2008). Avaliamos o nível de lesões CPDs geradas nas cepas de $C$. crescentus, bem como seu reparo. A cepa selvagem NA1000 é capaz de reparar boa parte das lesões CPDs induzidas por UV após 120 minutos, sendo que uma quantidade residual ainda permanece; as cepas deficientes em NER 
apresentaram remoção de CPDs pouco significativa, como esperado. O mais surpreendente foi a remoção de CPDs pelas cepas deficientes em síntese translesão: após 120 minutos, quase o total das lesões havia sido removido (capacidade de remoção superior a da cepa selvagem NA1000). A rápida remoção dos CPDs, no entanto, não se refletiu na recuperação do ciclo celular para estas cepas ou para a selvagem NA1000. A alteração dos níveis de ctrA após a irradiação reforça a idéia de que apenas a remoção das lesões CPDs não é suficiente para a recuperação do ciclo celular. A redução na síntese de ctrA pode resultar em alterações no ciclo celular, não só por sua ação sobre a proteína iniciadora da replicação do DNA, DnaA, mas também pelo efeito que CtrA possui sobre diversos genes essenciais para a progressão do ciclo celular, como genes que controlam a biossíntese do flagelo e do pili. Dentro deste contexto seria também interessante analisar os níveis protéicos de CtrA, bem como seu estado de fosforilação, uma vez que esta proteína é sabidamente sujeita a outros níveis de regulação além do transcricional (revisto por Curtis e Brun, 2010).

Reforçando esta idéia, observamos que a fotorreativação das cepas NA1000 e uvrA após a irradiação com luz UVC promove remoção eficiente das lesões CPDs, mas a progressão do ciclo celular não é retomada até três horas após a irradiação. Apenas com estes dados não podemos descartar a influência das lesões do tipo 6-4 fotoprodutos; dados indicam que a remoção destas lesões em E. coli irradiada com $200 \mathrm{~J} / \mathrm{m}^{2}$ alcança 80\% após 40 minutos (Koehler et al., 1996), mas os dímeros restante representam uma grande distorção para a molécula de DNA (revisto por Friedberg et al., 2006). Os níveis de ctrA, neste caso, também não são recuperados. Contrariando este fato, observamos uma melhora na sobrevivência tanto da cepa selvagem NA1000 quanto de uvrA após a fotorreativação. Isso indica que eventualmente as células são capazes de superar o bloqueio na progressão do ciclo celular e se dividem. Mais experimentos são necessários para determinar quais os fatores que influenciam no bloqueio da progressão do ciclo celular após irradiação, e se estes mecanismos são os mesmos em bactérias proficientes e deficientes em reparo. O que parece certo é que as lesões do tipo CPD são importantes para a morte celular observada após irradiação com luz UVC. A questão da recuperação do ciclo é mais complexa, e depende dos níveis de ctrA, podendo representar um mecanismo canônico de checkpoint, que merece ser melhor estudado. Acreditamos, no entanto, que este trabalho 
apresenta grandes avanços neste sentido e abre novas e interessantes perspectivas para o estudo da biologia de $C$. crescentus. 


\section{CONCLUSÕES}

Os resultados obtidos neste trabalho ajudam a expandir os conhecimentos sobre os mecanismos de reparo em $C$. crescentus. Caracterizamos a resposta SOS deste organismo e observamos que ela possui diferenças significativas em relação ao modelo mais estudado, $E$. coli. Nosso trabalho vai de encontro, portanto, a noção de os genes pertencentes a uma dada via em um organismo modelo nem sempre podem ser extrapolados a todos os demais.

Buscamos a caracterização de alguns mutantes em genes pertencentes ao regulon de LexA, como forma de melhor entender as respostas desta bactéria frente a injúrias a seu material genético. Oferecemos aqui alguns dados iniciais, mas com certeza, muito ainda precisa ser feito para melhor compreendermos como os genes CC_0627 e CC_2433 (que codificam proteínas hipotéticas), CC_2272 e CC_3731 (endonucleases III), CC_3225 (histidina quinase híbrida) e o operon codificado por CC_3038-CC_3037-CC_3036 (relacionado ao sistemas de toxina-antitoxina) se relacionam para auxiliar $C$. crescentus a enfrentar o meio ambiente que a cerca.

Neste trabalho também expandimos significativamente os conhecimentos a cerca dos mecanismos de chekpoints bacterianos. Ainda não fomos capazes de determinar com exatidão o mecanismo responsável pelo bloqueio da divisão celular no mutante lexA. Por outro lado, realizamos importantes avanços na descoberta do mecanismo que gera bloqueio de ciclo celular após irradiação com luz UVC nos mutantes deficientes em diferentes vias de reparo. Descrevemos aqui um mecanismo canônico de checkpoint que relaciona a integridade do material genético à correta progressão do ciclo celular, dependente dos níveis do regulador de resposta mestre CtrA e que não parece ser influenciado pela remoção de lesões CPDs.

Este trabalho estabeleceu importantes bases e métodos para que as relações entre danos ao DNA e seu reparo e a progressão do ciclo celular em $C$. crescentus possam ser mais bem estudadas e aprofundadas. 


\section{REFERENCIAS *}

Alekseyev YO, Hamm ML, Essigmann JM. Aflatoxin B1 formamidopyrimidine adducts are preferentially repaired by the nucleotide excision repair pathway in vivo. Carcinogenesis. 2004;25:1045-51.

Anderson RD, Veigl ML, Baxter J, Sedwick WD. Excision repair reduces doxorubicin-induced genotoxicity. Mutat Res. 1993;294:215-22.

Au N, Kuester-Schoek E, Mandava V, Bothwell LE, Canny SP, Chachu K, Colavito SA, Fuller SN, Groban ES, Hensley LA, O'Brien TC, Shah A, Tierney JT, Tomm LL, O'Gara TM, Goranov Al, Grossman AD, Lovett CM. Genetic composition of the Bacillus subtilis SOS System. J Bacteriol. 2005;187:7655-66.

Autret S, Levine A, Holland IB, Seror SJ. Cell cycle checkpoints in bacteria. Biochemie. 1997;79:549-54.

Bagg A, Kenyon CJ, Walker GC. Inducibility of a gene product required for UV and chemical mutagenesis in Escherichia coli. PNAS. 1961;78:5749-53.

Battista J R, Ohta T, Nohmi T, Sun W, Walker GC. Dominant negative umuD mutations decreasing RecA-mediated cleavage suggest roles for intact UmuD in modulating SOS mutagenesis. PNAS. 1990;87:7190-4.

*De acordo com: International Committee of Medical Journal Editors. Uniform requirements for manuscripts submitted to Biomedical Journal: sample references. Available from: http://www.icmje.org [2007 May 22]. 
Birnboim HC, Doly J. A rapid alkaline extraction procedure for screening recombinant plasmid DNA. Nucleic Acids Res, 1979;7(6):1513-23.

Bjelland S, Seeberg E. Different efficiencies of the Tag and AlkA from Escherichia coli in the removal of 3-methyladenine from single-stranded DNA. FEBS Lett. 1996;397:127-9.

Black C G, Fyfe JAM, Davies JK. Absence of an SOS-like system in Neisseria gonorrhoeae. Gene. 1998;208:61-6.

Brooks K, Clark AJ. Behavior of lamba bacteriophage in a recombination-deficient strain of Escherichia coli. J Virol. 1967;1:283-93.

Brooks PC, Movahedzadeh F, Davis EO. Identification of some DNA damage-inducible genes of Mycobacterium tuberculosis: apparent lack of correlation with LexA binding. J Bacteriol. 2001;183(15):4459-67.

Buts L, Lah J, Dao-Thi MH, Wyns L, Loris R. Toxin-antitoxin modules as bacterial metabolic stress managers. Trends Biochem Sci. 2005;30:672-9.

Campoy S, Mazon G, Fernandez de Henestrosa AR, Llagostera M, Monteiro PB, Barbe J. A new regulatory DNA motif of the gamma subclass Proteobacteria: identification of the LexA protein binding site of the plant pathogen Xylella fastidiosa. Microbiology. 2002;148:3583-97.

Campoy S, Fontes M, Padmanabhan S, Cortes P, Llagostera M, Barbe J. LexA-independent DNA damage-mediated induction of gene expression in Myxococcus xanthus. Mol Microbiol. 2003;49(3):769-81.

Campoy S, Salvador N, Cortes P, Erill I, Barbe J. Expression of canonical SOS genes is not under LexA repression in Bdellovibrio bacteriovorus. J Bacteriol. 2005;187:5367-75. 
Chaney SG, Campbell SL, Temple B, Basset E, Wu Y, Faldu M. Protein interactions with platinumDNA adducts: from structure to function. J Inorg Biochem. 2004;98:1551-9.

Chauhan A, Lofton H, Maloney E, Moore J, Fol M, Madiraju MV, Rajagopalan M. Interference of Mycobacterium tuberculosis cell division by Rv2719c, a cell wall hydrolase. Mol Microbiol. 2006;62:132-47.

Cirz RT, O'Neill BM, Hammond JA, Head SR, Romesberg FE. Defining the Pseudomonas aeruginosa SOS response and its role in the global response to the antibiotic ciprofloxacin. J Bacteriol. 2006;188:7101-10.

Cirz RT, Jones MB, Gingles NA, Minogue TD, Jarrahi B, Peterson SN, Romesberg FE. Complete and SOS-mediated response of Staphylococcus aureus to the antibiotic ciprofloxacin. J Bacteriol. 2007;189:531-9.

Colombi D, Gomes SL. An alkB gene homolog is differentially transcribed during the Caulobacter crescentus cell cycle. J Bacteriol. 1997,179:3139-45.

Cooper S. Checkpoints and restriction points in bacteria and eukaryotic cells. BioEssays. 2006;28(10):1035-9.

Courcelle J, Khodursky A, Peter B, Brown PO , Hanawalt PC. Comparative gene expression profiles following UV exposure in wild-type and SOS-deficient Escherichia coli. Genetics. 2001;158:41-64.

Crowley DJ, Courcelle J. Answering the call: coping with DNA damage at the most inopportune time. J Biomedicine and Biotechnology. 2002;2(2):66-74. 
Cuñe J, Cullen P, Mazon G, Campoy S, Adler B, Barbe J. The Leptospira interrogans lexA gene is not autoregulated. J Bacteriol. 2005;187:5841-5.

Cunningham RP, Weiss B. Endonuclease III (nth) mutants of Escherichia coli. PNAS. 1985;82:4748.

Curtis PD, Brun YV. Getting in the loop: regulation of development in Caulobacter crescentus. Microbiology and molecular biology reviews. 2010;74(1):13-41.

Davis EO, Dullaghan EM, Rand L. Definition of the mycobacterial SOS box and use to identify LexA-regulated genes in Mycobacterium tuberculosis. J Bacteriol. 2002;184:3287-95.

Defais $\mathrm{M}$, Fauquet $\mathrm{P}$, Radman $\mathrm{M}$, Errera $\mathrm{M}$. Ultraviolet reactivation and ultraviolet mutagenesis of lambda in different genetic systems. Virology. 1971;43:495-503.

Domian IJ, Reisenauer A, Shapiro L. Feedback control of a master cell-cycle regulator. PNAS. 1999;96:6648-53.

Ely B. Genetics of Caulobacter crescentus. Methods Enzymol. 1991;204:372-84.

Epe B, Pflaum M, Häring M, Hegler J, Rüdiger H. Use of repair endonucleases to characterize DNA damage induced by reactive oxygen species in cellular and cell-free systems. Toxicology Letters. 1993;67:57-72.

Erill I, Escribano M, Campoy S, Barbe J. In silico analysis reveals substantial variability in the gene contents of the gamma proteobacteria LexA regulon. Bioinformatics. 2003;19:2225-36. 
Erill I, Jara M, Salvador N, Escribano M, Campoy S, Barbe J. Differences in LexA regulon structure among Proteobacteria through in vivo assisted comparative genomics. Nucleic Acids Res. 2004;32:6617-26.

Falnes PO, Johansen RF, Seeberg E. AlkB-mediated oxidative demethylation reverses DNA damage in Escherichia coli. Nature. 2002;419:178-82.

Fernandez de Henestrosa A, Ogi T, Aoyagi S, Chafin D, Hayes JJ, Ohmori H, Woodgate R. Identification of additional genes belonging to the LexA regulon in Escherichia coli. Mol Microbiol. 2000;35:1560-72.

Fernandez de Henestrosa AR, Cune J, Erill I, Magnuson JK, Barbe J. A green nonsulfur bacterium, Dehalococcoides ethenogenes, with the LexA binding sequence found in gram-positive organisms. J Bacteriol. 2002;184:6073-80.

Friedberg E C, Walker GC, Siede W, Wood RD, Ellenberger T. DNA repair and mutagenesis. Washington, D.C.: ASM Press; 2006.

Galhardo RS, Rocha RP, Marques MV, Menck CFM. An SOS-regulated operon involved in damage-inducible mutagenesis in Caulobacter crescentus. Nucleic Acids Res. 2005;33:2603-14.

Garibyan J, Huang T, Kim M, Wollf E, Nguyen A, Nguyen T, Diep A, Hu K, Iverson A, Yang H, Miller $\mathrm{JH}$. Use of the $r p o B$ gene to determine the specificity of base substitution mutations on Escherichia coli chromosome. DNA Repair. 2003;2(5):593-608.

Gerdes K, Christensen SK, Lobner-Olesen A. Prokaryotic toxin-antitoxin stress response loci. Nature Rev Microbiol. 2005;3:371-82. 
Gober JW, Shapiro L. A developmentally regulated Caulobacter flagellar promoter is activated by 3' enhancer and IHF binding elements. Mol Biol Cell. 1992;3:913-6.

Gutenkust K, Phunpruch S, Schwarz C, Schuchardt S, Shulz-Friedrich R, Appel J. LexA regulates the bidirectional hydrogenase in the cyanobacterium Synechocystis sp. PCC 6803 as a transcriptional activator. Mol Microbiol. 2005;58:810-23.

Halliwell B, Gutteridge MC. Free Radicals in Biology and Medicine. 3rd ed. Oxford: Oxford University Press; 2003.

Hanahan D. Studies on transformation of Escherichia coli with plasmids. J Mol Biol. 1983;166(4):557-80.

Hartwell LH, Weinert TA. Checkpoints: controls that ensure the order of cell cycle events. Science. 1989;246:629-34.

Heller RC, Marians KJ. Replication fork reactivation downstream of a blocked nascent leading strand. Nature. 2006;439:557-62.

Helmstetter CE, Pierucci O. Cell division during inhibition of deoxyribonucleic acid synthesis in Escherichia coli. J Bacteriol. 1968;95:1627-33.

Howard-Flanders P, Boyce RP. DNA repair and genetic recombination: studies on mutant of Escherichia coli defective in these processes. Radiat Res Suppl. 1966;6:156.

Howard-Flanders P, Boyce RP, Theriot L. Three loci in Escherichia coli K-12 that control the excision of pyrimidine dimers and certain other mutagen products from DNA. Genetics. 1966;53:1119-36. 
Huismanm O, D'Ari R, Gottesman S. Cell division control in Escherichia coli: specific induction of the SOS function SfiA protein is sufficient to block septation. PNAS. 1984;81:4490-4.

Iba H, Fukuda A, Okada Y. Synchronous cell differentiation in Caulobacter crescentus. Jpn J Microbiol. 1975;19:441-6.

Inagaki F, Takai K, Hirayama H, Yamato Y, Nealson KH, Horikoshi K. Distribution and phylogenetic diversity of the subsurface microbial community in a Japanese epithermal gold mine. Extremophiles. 2003;7:307-17.

Italiani VCS, Marques MV. The transcription termination factor Rho is essential and autoregulated in C. crescentus. J Bacteriol. 2005;187(12):4290-4.

Jara, M, Nuñez C, Campoy S, Fernandez de Henestrosa AR, Lovley D, Barbe J. Geobacter sulfurreducens has two autoregulated lexA genes whose products do not bind the recA promoter: differing responses of lexA and recA to DNA damage. J Bacteriol. 2003;185:2493-502.

Jenal U, Fuchs T. An essential protease involved in bacterial cell-cycle control. EMBO J. 1998;17:5658-69.

Jochmann N, Kurze AK, Czaja LF, Brinkrolf K, Brune I, Hüser AT, Hansmeier N, Pühler A, Borovok I, Tauch A. Genetic makeup of the Corynebacterium glutamicum LexA regulon deduced from comparative transcriptomics and in vitro DNA band shift assay. Microbiology. 2009;155:145977.

Judd EM, Ryan KR, Moerner WE, Shapiro L, McAdams HH. Fluorescence bleaching reveals asymmetric compartment formation prior to cell division in Caulobacter. PNAS. 2003;100:823540. 
Kato T. Effects of chloramphenicol and caffeine on post-replication repair in $u v r A^{-} u m u C^{-}$and uvrA- recF strains of Escherichia coli K-12. Mol Gen Genet. 1997;156:115-20.

Kawai Y, Moriya S, Ogasawara N. Identification of a protein, YneA, responsible for cell division suppression during the SOS response in Bacillus subtilis. Mol Microbiol. 2003;47(4):1113-22.

Kenyon CJ, Walker GC. DNA-damaging agents stimulate gene expression at specific loci in Escherichia coli. PNAS. 1980;77(5):2819-23.

Khill PP, Camerini-Otero RD. Over 1000 genes are involved in the DNA damage response in Escherichia coli. Mol Microbiol. 2002;44:89-105.

Koehler DR, Courcelle J, Hanawalt PC. Kinetics of Pyrimidine (6-4) Pyrimidone photoproduct repair in Escherichia coli. J Bacteriol. 1996;178(5):1347-50.

Kogoma T. Two types of temperature sensitivity in DNA replication of an Escherichia coli dnaB mutant. J Mol Biol. 1976;103(1):197-9.

Kuluncsics Z, Perdiz D, Brulay E, Muel B, Sage E. Wavelength dependence of ultraviolet-induced DNA damage distribution: involvment of direct and indirect mechanisms and possible artifacts. J Photochem Photobiol. 1999;49(1):71-80.

Kunkel T A. DNA replication fidelity. J Biol Chem. 2004;279(17):16895-8.

Laub MT, McAdams HH, Feldblyum T, Fraser CM, Shapiro L. Global analysis of the genetic network controlling a bacterial cell cycle. Science. 2000;290:2144-8.

Laub MT, Chen SL, Shapiro L, McAdams HH. Genes directly regulated by CtrA, a master regulator of the Caulobacter cell cycle. PNAS. 2002;99(7):4632-7. 
Li S, Xu M, Su Z. Computational analysis of LexA regulons in Cyanobacteria. BMC Genomics. 2010;11:527-43.

Lima-Bessa KM, Armelini MG, Chiganças V, Jacysyn JF, Amarante-Mendes GP, Sarasin A, Menck CFM. CPDs and 6-4PPs play different roles in UV-induced cell death in normal and NER-deficient human cells. DNA Repair. 2008;7:303-12.

Maaloe O, Hanawalt PC. Thymine deficiency and the normal DNA replication cycle. J Mol Biol. 1961;3:144-55.

MacRae JD, Smit J. Characterization of caulobacter isolated from wastewater treatment systems. Appl Environ Microbiol. 1991;57:751-8.

Malakooti J, Ely B. Principal sigma subunit of the Caulobacter crescentus RNA polymerase. J Bacteriol. 1995;177:6854-60.

Mannisto MK, Tiirola MA, Salkinoja-Salonen MS, Kulomaa MS, Puhakka JA. Diversity of chlorophenol-degrading bacteria isolated from contaminated boreal groundwater. Arch Microbiol. 1999;171:189-97.

Marks ME, Castro-Rojas CM, Teiling C, Du L, Kapatral V, Walunas TL, Crosson S. The genetic basis of laboratory adaptation in Caulobacter crescentus. J Bacteriol. 2010;192(14):3678-88.

Marques RCP. Identificação de genes de reparo de DNA em Caulobacter crescentus através de seleção de clones sensíveis a agentes genotóxicos. [Tese (Doutorado em Microbiologia)]. São Paulo: Instituto de Ciências Biomédicas da Universidade de São Paulo; 2008. 
Martins-Pinheiro M. Busca por genes relacionados a fenótipos mutadores em Caulobacter crescentus. [Tese (Doutorado em Microbiologia)]. São Paulo: Instituto de Ciências Biomédicas da Universidade de São Paulo; 2007.

Martins-Pinheiro M, Marques RC, Menck CFM. Genome analysis of DNA repair genes in the alpha proteobacterium Caulobacter crescentus. BMC Microbiology. 2007;12:7-17.

Mazon G, Lucena JM, Campoy S, Fernandez de Henestrosa AR, Candau P, Barbe J. LexA-binding sequences in Gram-positive and cyanobacteria are closely related. Mol Gen Genomics. 2004;271:40-9.

McCullough AK, Dosdon ML, Lloyd RS. Initiation of base excision repair: glycosylase mechanisms and structures. Annu Rev Biochem. 1999;68:255-85.

McGrath PT, Lee H, Zhang L, Iniesta AA, Hottes AK, Tan MH, Hillson NJ, Hu P, Shapiro L, McAdams HH. High-throughput identification of transcription start sites, conserved promoter motifs and predicted regulons. Nat Biotechnol. 2007;25(5):584-92.

Melamede RJ, Hatahet Z, Kow YW, Ide H, Wallace S. Isolation and characterization of endonuclease VIII from Escherichia coli. Biochemie. 1994;33(5):1255-64.

Metz AH, Hollis T, Eichman BF. DNA damage recognition and repair by 3-methyladenine DNA glycosilase I (TAG). EMBO J. 2007;26:2411-20.

Michel B. After 30 years of study, the bacterial SOS response still surprises us. PLos Biology. 2005;3(7):1174-6. 
Miller JH. A short course in Bacterial Genetics - A laboratory manual and handbook for Escherichia coli and related bacteria. California: Cold Spring Harbor Laboratory Press; 1992. 3 vol.

Moolenar GF, van Rossum-Fikkert S, van Kesteren M, Goosen N. Cho, a second endonuclease involved in Escherichia coli nucleotide excision repair. PNAS. 2002;99:1467-72.

Moriwaki S, Takahashi Y. Photoaging and DNA repair. J Dermatol Sci. 2008;50(3):169-76.

Mount DW. A mutant of Escherichia coli showing constitutive expression of the lysogenic induction and error-prone DNA repair pathways. PNAS. 1977;74:300-4.

Mukherjee A, Cao C, Lutkenhaus J. Inhibition of FtsZ polymerization by SulA, an inhibitor of septation in Escherichia coli. PNAS. 1998;95:2885-90.

Nicholson WL, Chooback L, Fajardo-Cavazos P. Analysis of spore photoproduct lyase operon (sp/AB) function using targeted deletion-insertion mutations spanning the Bacillus subtilis operons ptsHI and splAB. Mol Gen Genet. 1977;255(6):587-94.

Nierman WC, Feldblyum TV, Laub MT, Paulsen IA, Nelson KE, Eisen J, Heidelberg JF, Alley MRK, Ohta N, Maddock JR, Potocka I, Nelson WC, Newton A, Stephens C, Phadke ND, Ely B, DeBoy RT, Dodson RJ, Durkin AS, Gwinn ML, Haft DH, Kolonay JF, Smit J, Craven MB, Khouri H, Shetty J, Berry K, Utterback T, Tran K, Wolf A, Vamathevan J, Ermolaeva M, White O, Salzberg SL, Venter JC, Shapiro L, Fraser CM. Complete genome sequence of Caulobacter crescentus. PNAS. 2001;98(7):4136-41.

North NN, Dollhopf SL, Petrie L, Istok JD, Balkwill DL, Kostka JE. Change in bacterial community structure during in situ biostimulation of subsurface sediment cocontaminated with uranium and nitrate. Appl Environ Microbiol. 2004;70:4911-20. 
Ogino $\mathrm{H}$, Teramoto $\mathrm{H}$, Inui M, Yukawa H. DivS, a novel SOS-inducible cell-division suppressor in Corynebacterium glutamicum. Mol Microbiol. 2007;67(3):597-608.

Öztürk N, Kao YT, Selby CP, Kavakh IH, Partch CL, Zhong D, Sancar A. Purification and characterization of a type III photolyase from Caulobacter crescentus. Biochemistry. 2008;47:10255-61.

Pandey DP, Gerdes K. Toxin-antitoxin loci are highly abundant in free-living but lost from hostassociated prokaryotes. Nucleic Acids Research. 2005;33(3):966-76.

Pfaffl MW. A new mathematical model for relative quantification in real-time RT-PCR. Nucleic Acids Res. 2001;29:c45.

Pirrung MC. Histidine kinases and two-component signal transduction systems. Chem Biol. 1999;6:167-75.

Poindexter JS. Biological properties and classification of the Caulobacter group. Bacteriol Rev. 1964;28:231-95.

Prenkti $\mathrm{P}$, Krisch HM. In vitro insertional mutagenesis with a selectable DNA fragment. Gene. 1984;29:303-13.

Quillardet P, Rouffaud MA, Bouige P. DNA array analysis of gene expression in response to UV irradiation in Escherichia coli. Res Microbiol. 2003;154:559-72.

Quon KC, Marczynski GT, Shapiro L. Cell cycle control by an essential bacterial two-component signal transduction protein. Cell. 1996;84(1):83-93. 
Radman M. An Endonuclease from Escherichia coli that introduces single polynucleotide chain scissions in ultraviolet-irradiated DNA. J Biol Chem. 1976;251(5):1438-45.

Ramaswamy M, Yeung AT. Sequence-specific interaction of UvrABC endonuclease with psoralen interstrand crossslinks. J Biol Chem. 1994;269:485-92.

Ribeiro DT, Madzak C, Sarasin A, Di Mascio P, Sies H, Menck CFM. Singlet oxygen induced DNA damage and mutagenicity in a single-stranded SV40-based shuttle vector. Photochem Photobiol. 1992;55(1):39-45.

Rivera E, Vila L, Barbe J. The uvrB gene of Pseudomonas aeruginosa is not DNA damage inducible. J Bacteriol. 1996;178(18):5550-4.

Rivera E, Vila L, Barbe J. Expression of the Pseudomonas aeruginosa uvrA gene is constitutive. Mutat Res. 1997;377(1):149-55.

Roberts RC, Toochinda C, Avedissian M, Baldini RL, Gomes SL, Shapiro L. Identification of a Caulobacter crescentus operon encoding hcrA, involved in negatively regulating heat-inducible transcription and the chaperone gene grpE. J Bacteriol. 1996;178:1829-41.

Rocha RP, Paquola ACM, Marques MV, Menck CFM, Galhardo RS. Characterization of the SOS regulon of Caulobacter crescentus. J Bacteriol. 2008;190(4):1209-18.

Saito Y, Uraki F, Nakajima S, Asaeda A, Ono K, Kubo K, Yamamoto K. Characterization of endonuclease III (nth) and endonuclease VIII (nei) mutants of Escherichia coli K-12. J Bacteriol. 1997;179(11):3783-5.

Sancar GB, Sancar A. Structure and function of DNA photolyases. Tends Biochem. 1987;12:25961. 
Sassanfar M, Roberts JW. Nature of the SOS-inducing signal in Escherichia coli: the involvement of DNA replication. J Mol Biol. 1990;212:79-96.

Schuch AP, Galhardo RS, Lima-Bessa KM, Schuch NJ, Menck CFM. Development of a DNAdosimeter system for monitoring the effects of solar-ultraviolet radiation. Photochem Photobiol. Sci. 2009;8(1):111-20.

Simon R, Priefer U, Pühler A. A Broad Host Range Mobilization System for In Vivo Genetic Engineering: Transposon Mutagenesis in Gram Negative Bacteria. Nature Biotechnology. 1983;1:784-91.

Skerker JM, Laub MT. Cell-cycle progression and the generation of asymmetry in Caulobacter crescentus. Nature Reviews Microbiology. 2004;2:325-37.

Skerker JM, Prasol MS, Perchuk BS, Biondi EG, Laub MT. Two-component signal transduction pathways regulation growth and cell cycle progression in a bacterium: a system-level analysis. PLoS Biol. 2005;3:e334.

Steinborn G. Uvm mutants of Escherichia coli K12 deficient in UV mutagenesis. I. Isolation of uvm mutants and their phenotypical characterization in DNA repair and mutagenesis. Mol Gen Genet. 1978;165:87-93.

Sung HM, Yeamans G, Ross CA Yasbin RE. Roles of YqjH and YqjW, Homologues of the Escherichia coli UmuC/DinB or $\mathrm{Y}$ Superfamily of DNA polymerases, in stationary-phase mutagenesis and UV-induced mutagenesis in Bacillus subtilis. J Bacteriol. 2003;185(7):2153-60.

Tapias A, Barbe J. Regulation of divergent transcription from the uvrA-ssb promoters in Sinorhizobium meliloti. Mol Gen Genet. 1999;262:121-30. 
Tapias A, Fernandez S, Alonso JC, Barbe J. Rhodobacter sphaeroides LexA has dual activity: optimizing and repressing recA gene transcription. Nucleic Acids Res. 2002;30(7):1539-46.

Todo T. Functional diversity of the DNA photolyase / blue light receptor family. Mutat Res. 1999;434:89-97.

Tsai JW, Alley MR. Proteolysis of the McpA chemoreceptor does not require the Caulobacter major chemotaxis operon. J Bacteriol. 2000;182:504-7.

Tsilibaris V, Maenhaut-Michel G, Mine N, Van Melderen L. What is the benefit to Escherichia coli of having multiple toxin-antitoxin systems in its genome? J Bacteriol. 2007;189(17):6101-8.

University of Yale, Jacobs Wagner Lab. Caulobacter crescentus cell cycle. 2007. Available from: www.yale.edu/jacobswagner/images/cell_cycle.gif. [2009 Dec. 14].

Van der Veen S, van Schalkwijk S, Molenaar D, de Vos WM, Abee T, Wells-Bennik MHJ. The SOS response of Listeria monocytogenesis is involved in stress resistance and mutagenesis. Microbiology. 2010;156:374-84.

Van Houten B, Eisen JA, Hanawalt PC. A cut above: Discovery of an alternative excision repair pathway in bacteria. PNAS. 2002;99(5):2581-3.

Van Houten B, Croteau DL, DellaVecchia MJ, Wang H, Kisker C. "Close fitting sleeves": DNA damage recognition by the UvrABC nuclease system. Mutat Res. 2005;577:92-117.

Van Steeg H, Kraemer KH. Xeroderma pigmentosum and the role of UV-induced DNA damage in skin cancer. Mol Med Today. 1996;5:86-94. 
Viollier PH, Thanbichler M, McGrath PT, West L, Meewan M, McAdams HH, Shapiro L. Rapid and sequential movement of individual chromosomal loci to specific subcellular locations during bacterial DNA replication. PNAS. 2004;101(25):9257-62.

Voloshin ON, Ramirez BE, Bax A, Cameirini-Otero RD. A model for the abrogation of the SOS response by an SOS protein: a negatively charged helix in Dinl mimics DNA in its interaction with RecA. Genes. Dev. 2001;15(4):415-27.

Weigle JJ. Induction of mutation in bacterial virus. PNAS. 1953;39:628-36.

Wortinger M, Sackett MJ, Brun YV. CtrA mediates a DNA replication checkpoint that prevents cell division in Caulobacter crescentus. EMBO J. 2000;19(17):4503-12.

Yang L, Arora K, Beard WA, Wilson SH, Schlick T. Critical role of magnesium ions in DNA polymerase $\beta$ s closing and active site assembly. J Am Chem Soc. 2004;126:8441-53.

Yasuda T, Morimatsu K, Horii T, Nagata T, Ohmori H. Inhibition of Escherichia coli RecA coprotease activities by Dinl. EMBO J. 1998;17(11):3207-16. 
ANEXOS 
ANEXO A: Oligonucleotídeos utilizados neste trabalho.

(Continua)

\begin{tabular}{|c|c|c|}
\hline Oligonucleotídeo & Seqüência $\left(5^{\prime} \rightarrow 3^{\prime}\right)$ & Características e finalidade \\
\hline $0041-112 \mathrm{~F}$ & TGCGCCTATCTCGGCTTAC & qRT-PCR (CC_0041) \\
\hline 0041-164R & GGCGTGTTCATCCAGATCAC & qRT-PCR (CC_0041) \\
\hline 0085-593F & TCGGCGACTACGACTTCCT & qRT-PCR (CC_0085) \\
\hline 0085-660R & GATCGCTGCGATGTCGATC & qRT-PCR (CC_0085) \\
\hline 0088-1047R & TTCATTGTGGCTGCCCG & qRT-PCR (CC_0088) \\
\hline 0088-997F & GTGGCGAGAATCATGCGC & qRT-PCR (CC_0088) \\
\hline 0140-530F & CGGGCCCGATCATTGAG & qRT-PCR (CC_0140) \\
\hline 0140-580R & CTTTGACGTCGCGCAGG & qRT-PCR (CC_0140) \\
\hline $0271-505 F$ & GGCGAGCAGACTCTCCGTA & qRT-PCR (CC_0271) \\
\hline 0271-582R & GACGCTGAACTGTTCCTGGA & qRT-PCR (CC_0271) \\
\hline $0382-474 \mathrm{~F}$ & CAAGTTCTGCGGACCGGT & qRT-PCR (CC_0382) \\
\hline 0382-537R & GTGGTCGTTGACCAGCCC & qRT-PCR (CC_0382) \\
\hline $0383-22 F$ & TCTTGCGCGTGGAGTCTG & qRT-PCR (CC_0383) \\
\hline 0383-75R & CATCGGCGCGTTTTCC & qRT-PCR (CC_0383) \\
\hline $0392-455 F$ & GGTTCCCGTTCAAGACCGT & qRT-PCR (CC_0392) \\
\hline 0392-506R & TCCGAGACCACGAACATCAG & qRT-PCR (CC_0392) \\
\hline $0398-304 F$ & CGCCGCATCGACATCCT & qRT-PCR (CC_0398) \\
\hline 0398-354R & CAGCGGACTGGCCATGAC & qRT-PCR (CC_0398) \\
\hline $0420-171 \mathrm{~F}$ & GGCGCTATTAGAGATGGCG & qRT-PCR (CC_0420) \\
\hline $0420-276 R$ & CTGATTGACCGTTCCCAGG & qRT-PCR (CC_0420) \\
\hline $0510-422 F$ & CCATGATCAAGGACGGCCT & qRT-PCR (CC_0510) \\
\hline 0510-473R & TGACCCATGTGGTAACCGTG & qRT-PCR (CC_0510) \\
\hline 0539-1830F & GTCGTACCGCGCCAATATC & qRT-PCR (CC 0539) \\
\hline
\end{tabular}


ANEXO A: Oligonucleotídeos utilizados neste trabalho.

(Continuação)

\begin{tabular}{|c|c|c|}
\hline Oligonucleotídeo & Seqüência $\left(5^{\prime} \rightarrow 3^{\prime}\right)$ & Características e finalidade \\
\hline 0539-1928R & CGGACCTCGGTGTTCTGAG & qRT-PCR (CC_0539) \\
\hline 0550-369F & CACCAACGTGGTGGCCTAT & qRT-PCR (CC_0550) \\
\hline $0550-424 R$ & CGGTGAAGAACATCTGCTCG & qRT-PCR (CC_0550) \\
\hline 0575-330F & CTCAGACGACGTACGGCAAC & qRT-PCR (CC_0575) \\
\hline 0575-381R & GCGCACGAGATTGTCATACC & qRT-PCR (CC_0575) \\
\hline 0627-171F2 & TGCGGCCCGAAAGCT & qRT-PCR (CC_0627) \\
\hline 0627-229R2 & TGAAGGCTCCACGCTCG & qRT-PCR (CC_0627) \\
\hline 0686-123R & GACGACTTCGCCTTCTTGC & qRT-PCR (CC_0686) \\
\hline $0686-72 F$ & GATCATCATCCCCGACACC & qRT-PCR (CC_0686) \\
\hline $0692-265 F$ & CTGTGCATGCTGACCTTCG & qRT-PCR (CC_0692) \\
\hline 0692-318R & GGTGGTGAACTTCAGGACCTG & qRT-PCR (CC_0692) \\
\hline $0781-171 \mathrm{~F}$ & CCAGTCCGCCAACCTCTC & qRT-PCR (CC_0781) \\
\hline 0781-237R & CTGCATCGTTTCGATCGC & qRT-PCR (CC_1781) \\
\hline 0782-139F & CGCCATATGAGCTCCAAGG & qRT-PCR (CC_0782) \\
\hline $0782-214 R$ & CCTTGTCCAGGTGCCAGTC & qRT-PCR (CC_0782) \\
\hline $0975-352 F$ & ACGCTGACCTACGAGGAAGC & qRT-PCR (CC_0975) \\
\hline $0975-422 R$ & GCTTGGTCAGGCACAGTGAG & qRT-PCR (CC_0975) \\
\hline 1054-146R & TCGACGAAGTCGCGCAA & qRT-PCR (CC_1054) \\
\hline $1054-96 F$ & GGACCAGCCCAAGACGG & qRT-PCR (CC_1054) \\
\hline 1086-793F & GAGGGCCTGAAGGAAACCC & qRT-PCR (CC_1086) \\
\hline $1086-843 R$ & TCGGTTCATCGCCTCCG & qRT-PCR (CC_1086) \\
\hline $1087-503 F$ & GCGAGATGGGCGACAGC & qRT-PCR (CC_1087) \\
\hline
\end{tabular}


ANEXO A: Oligonucleotídeos utilizados neste trabalho.

(Continuação)

\begin{tabular}{|c|c|c|}
\hline Oligonucleotídeo & Seqüência $\left(5^{\prime} \rightarrow 3^{\prime}\right)$ & Características e finalidade \\
\hline $1087-553 R$ & CCTGGCTCATCAGACGGG & qRT-PCR (CC_1087) \\
\hline \multicolumn{3}{|l|}{$1272-782 F$} \\
\hline $1272-841 R$ & CGCCGATGTAGACGATGTTG & qRT-PCR (CC_1272) \\
\hline $1330-494 \mathrm{~F}$ & TCATCACCAAGTCGGCGC & qRT-PCR (CC_1330) \\
\hline 1330-544R & TGCGGCTCAGCACATCC & qRT-PCR (CC_1330) \\
\hline $1468-212 F$ & ATCTGCGCAAGGGCTCG & qRT-PCR (CC_1468) \\
\hline $1468-262 R$ & TGCGGGTCTGCAGCG & qRT-PCR (CC_1468) \\
\hline $1528-727 F$ & CTGGACGAGTTCCAGCAGC & qRT-PCR (CC_1528) \\
\hline 1528-784R & TGGTGTCCTGGTACTCGTCG & qRT-PCR (CC_1528) \\
\hline $1531-355 F$ & TTCGTTCGCGAGAAACGC & qRT-PCR (CC_1531) \\
\hline 1531-405R & CAGGGTCCCGCCACCTT & qRT-PCR (CC_1531) \\
\hline $1532-175 F$ & GTGGTCGGTTCTGACGGC & qRT-PCR (CC_1532) \\
\hline $1532-225 R$ & GCCGGCGATATGGTCCA & qRT-PCR (CC_1532) \\
\hline $1543-565 F$ & GACAAGATGGACGAGGCGA & qRT-PCR (CC_1543) \\
\hline 1543-618R & CAGCAGGTTATGGTGGCGA & qRT-PCR (CC_1543) \\
\hline 1665-611F2 & TCTCGACCGACCTGATGGA & qRT-PCR (CC_1665) \\
\hline 1665-671R2 & ATCAAGTCGGACGGGTGC & qRT-PCR (CC_1665) \\
\hline 1729-1048R & TGCTGATCGAGAAGGTGCC & qRT-PCR (CC_1729) \\
\hline 1729-990F & CGCCAAGGACA AGAAGCTG & qRT-PCR (CC_1729) \\
\hline $1836-101 \mathrm{~F}$ & TCTCGCAGAAGATGCTGACC & qRT-PCR (CC_1836) \\
\hline $1836-151 R$ & ATCCGTTCTGCTCCAGATCC & qRT-PCR (CC_1836) \\
\hline 1926-1689F & CCTCAAGACGCTGACGGTG & qRT-PCR (CC_1926) \\
\hline $1926-1741 R$ & TGGACTGGGCGATGACGTGC & qRT-PCR (CC_1926) \\
\hline
\end{tabular}


ANEXO A: Oligonucleotídeos utilizados neste trabalho.

(Continuação)

\begin{tabular}{|c|c|c|}
\hline Oligonucleotídeo & Seqüência $\left(5^{\prime} \rightarrow 3^{\prime}\right)$ & Características e finalidade \\
\hline 1927-110R & TTGGCCACCGTGCACAT & qRT-PCR (CC_1927) \\
\hline $1927-60 F$ & CGCGTTTCTTGAGGTGCTTC & qRT-PCR (CC_1927) \\
\hline 1928-310F & GTGGATGAGCTGGTGCGC & qRT-PCR (CC_1928) \\
\hline 1928-360R & CAGGGTGATCTCGCCGG & qRT-PCR (CC_1928) \\
\hline 1983-66R3 & CTCGCCGATGGCAAGGT & qRT-PCR (CC_1983) \\
\hline 1983-7F3 & ATCGGCCTTTTCCATCCG & qRT-PCR (CC_1983) \\
\hline 2017-110F & ACAGCGTTGCAGAGGCTGT & qRT-PCR (CC_2017) \\
\hline 2017-166R & CCTGCGAGTCGTAGTTCGG & qRT-PCR (CC_2017) \\
\hline $2025-136 F$ & АTCTGGTTCTCCCTGCGTGT & qRT-PCR (CC_2025) \\
\hline 2025-191R & CATGCCGCCTGGAGACTAG & qRT-PCR (CC_2025) \\
\hline $2040-898 F$ & ACGGCGCTGGTATTCGTC & qRT-PCR (CC_2040) \\
\hline 2040-960R & CTCCCACAGTCGCTGGAAG & qRT-PCR (CC_2040) \\
\hline $2111-275 F$ & TGAGCCACCTGCTAATCGC & qRT-PCR (CC_2111) \\
\hline $2111-351 R$ & CAGCTGCAGGTCTTTGATGG & qRT-PCR (CC_2111) \\
\hline $2272-301 F$ & ATCGAGGAGAAGGTCGGCTG & qRT-PCR (CC_2272) \\
\hline $2272-352 R$ & CCTCAAGCGTCTTGAGGTGG & qRT-PCR (CC_2272) \\
\hline $2332-566 F$ & AGGACCCCACCGACATCAA & qRT-PCR (CC_2332) \\
\hline $2332-616 R$ & CGATGGCCAGTCGCATG & qRT-PCR (CC_2332) \\
\hline 2333-615F & GATCTTCAATCCGGCCCG & qRT-PCR (CC_2333) \\
\hline 2333-665R & GGCATTTCCTGGCGCAT & qRT-PCR (CC_2333) \\
\hline $2433-118 F$ & GCGCCGCTGGACTATGTG & qRT-PCR (CC_2433) \\
\hline $2433-168 R$ & CATGGCGGCCAGATTGAA & qRT-PCR (CC_2433) \\
\hline $2469-184 \mathrm{~F}$ & ACCAAGGCCGAGCTTAAGG & qRT-PCR (CC_2469) \\
\hline
\end{tabular}


ANEXO A: Oligonucleotídeos utilizados neste trabalho.

(Continuação)

\begin{tabular}{|c|c|c|}
\hline Oligonucleotídeo & Seqüência $\left(5^{\prime} \rightarrow 3^{\prime}\right)$ & Características e finalidade \\
\hline $2469-234 R$ & CCTGACCAGAGCGATCTCGT & qRT-PCR (CC_2469) \\
\hline 2498-169R & CCGGTCTTCTGTTGCTGGTC & qRT-PCR (CC_2498) \\
\hline $2498-81 F$ & ACAAGTCCGATGGCCGAAC & qRT-PCR (CC_2498) \\
\hline $2589-187 \mathrm{~F}$ & ATCGCGCCGGGTGAAG & qRT-PCR (CC_2589) \\
\hline $2589-237 R$ & CGTAAAGAGCGGCGGGTATA & qRT-PCR (CC_2589) \\
\hline $2590-1637 F$ & ACCTGGGCAATTCGGTGC & qRT-PCR (CC_2590) \\
\hline $2590-1689 R$ & GGTGAGGATGGCTTCCTCGT & qRT-PCR (CC_2590) \\
\hline $2630-768 F$ & TCACCAGTGGAACACCTCGT & qRT-PCR (CC_2630) \\
\hline $2630-822 R$ & CAGATAGGACGTGCCCTCG & qRT-PCR (CC_2630) \\
\hline $2878-252 F$ & CTTCGCCAAGACCCTTTTGC & qRT-PCR (CC_2878) \\
\hline $2878-302 R$ & TCCATCACCAGCTTGCCC & qRT-PCR (CC_2878) \\
\hline 2879-120F2 & AGAGGCCGAAGGCAAGGAT & qRT-PCR (CC_2879) \\
\hline 2879-174R2 & CATCACGTGGAGGGCGTC & qRT-PCR (CC_2879) \\
\hline 2880-140R & GAATGCTGGGCAAGCTGC & qRT-PCR (CC_2880) \\
\hline $2880-90 F$ & CCGGGCCATCGACCTTA & qRT-PCR (CC_2880) \\
\hline 2881-1025F & TCCTGGCCAATGTCCAGC & qRT-PCR (CC_2881) \\
\hline 2881-1089R & GCCGCTCTTCAGGGCG & qRT-PCR (CC_2881) \\
\hline 3036-FOW & ACTGGGTCTGTAGCGTCGCT & qRT-PCR (CC_3036) \\
\hline 3036-REV & GCGTCAGGGTCCCGAAC & qRT-PCR (CC_3036) \\
\hline 3037-FOW & GACACGGGTGACGCCG & qRT-PCR (CC_3037) \\
\hline 3037-REV & GCGAGCGATCAGACCCAG & qRT-PCR (CC_3037) \\
\hline 3038-FOW & CGGTGGCGACAAGAGCTCT & qRT-PCR (CC_3038) \\
\hline 3038-REV & ATCACCCTGGCCTTCTCGA & qRT-PCR (CC_3038) \\
\hline
\end{tabular}


ANEXO A: Oligonucleotídeos utilizados neste trabalho.

(Continuação)

\begin{tabular}{|c|c|c|}
\hline Oligonucleotídeo & Seqüência $\left(5^{\prime} \rightarrow 3^{\prime}\right)$ & Características e finalidade \\
\hline $3039-541 \mathrm{~F}$ & GGCCACTGCCTCAAGCAC & qRT-PCR (CC_3039) \\
\hline 3039-594R & GCGATTGGCGGTCAGCT & qRT-PCR (CC_3039) \\
\hline $3109-150 F$ & CTTCAAGCCCAACAGCTGG & qRT-PCR (CC_3109) \\
\hline $3109-214 R$ & TGACCGAGAACACGAAGTCG & qRT-PCR (CC_3109) \\
\hline $3130-822 F$ & CATGCACATCCACCAGTCG & qRT-PCR (CC_3130) \\
\hline $3130-885 R$ & CCCGTCCTCATCCGAGAA & qRT-PCR (CC_3130) \\
\hline $3164-223 F$ & TACGAGATCGCCAAGACCCT & qRT-PCR (CC_3164) \\
\hline $3164-274 R$ & GGCCGTCGAAGAAGAATGAC & qRT-PCR (CC_3164) \\
\hline 3214-1384F & ACCACGGCGAGCGTCAC & qRT-PCR (CC_3214) \\
\hline $3214-1439 R$ & GCAACGACAGGCTCGGC & qRT-PCR (CC_3214) \\
\hline $3225-1671 \mathrm{~F}$ & GATGGTGTACGGCTTTGCC & qRT-PCR (CC_3225) \\
\hline $3225-1743 R$ & GTGGCCCACCTCGGAAT & qRT-PCR (CC_3225) \\
\hline $3284-173 F$ & AGGCCGGTTACAAGGTGATC & qRT-PCR (CC_3284) \\
\hline $3284-312 R$ & CGAAAGCAGGCTATCGAGG & qRT-PCR (CC_3284) \\
\hline $3356-430 F$ & CAAACCCGCCTCACCCTC & qRT-PCR (CC_3356) \\
\hline $3356-482 R$ & AGCACCCGGCCCAAAG & qRT-PCR (CC_3356) \\
\hline $3370-150 F$ & CGATTACGACAAGCCCGAG & qRT-PCR (CC_3370) \\
\hline $3370-212 R$ & ATCAGCAGCAGCACATCGAC & qRT-PCR (CC_3370) \\
\hline $3380-328 \mathrm{~F}$ & GAGGTCTATCGCAAGGTGCTG & qRT-PCR (CC_3380) \\
\hline 3380-378R & GGTGAAGAACACCCCGTCC & qRT-PCR (CC_3380) \\
\hline $3424-123 F$ & CTTCGAGGGCCAGGGAAC & qRT-PCR (CC_3424) \\
\hline $3424-173 R$ & GACCCCTCCTGCGGCTT & qRT-PCR (CC_3424) \\
\hline $3467-160 \mathrm{~F}$ & GGCGACGTGCTGATCGT & qRT-PCR (CC_3467) \\
\hline
\end{tabular}


ANEXO A: Oligonucleotídeos utilizados neste trabalho.

(Continuação)

\begin{tabular}{|c|c|c|}
\hline Oligonucleotídeo & Seqüência $\left(5^{\prime} \rightarrow 3^{\prime}\right)$ & Características e finalidade \\
\hline $3467-216 R$ & CCGATCGACCCGGAAAT & qRT-PCR (CC_3467) \\
\hline $3514-468 F$ & CTCTGCCCAGCACGAACATA & qRT-PCR (CC_3514) \\
\hline $3514-518 R$ & GCGGTGGCATAGTCGTCAC & qRT-PCR (CC_3514) \\
\hline $3515-156 F$ & AGCGCCCCCTTGTAAACG & qRT-PCR (CC_3515) \\
\hline $3515-206 R$ & TGAACTGGCCCGAATTTCC & qRT-PCR (CC_3515) \\
\hline $3518-202 F 2$ & ATGCTGATGACCGAGGCG & qRT-PCR (CC_3518) \\
\hline $3518-256 R 2$ & GACGCGGCCAACGCT & qRT-PCR (CC_3518) \\
\hline $3620-200 F$ & ACGGCTCGATGCTGCTCTA & qRT-PCR (CC_3620) \\
\hline $3620-286 R$ & CCCACTGACGGAAGTTCTCG & qRT-PCR (CC_3620) \\
\hline ruvA-148F & GAGAGCCAGTGGAGCGAGAG & qRT-PCR (ruvA - CC_3237) \\
\hline ruvA-201R & GCGAGTGAGGAAGCCGTAGA & qRT-PCR (ruvA - CC_3237) \\
\hline ruvB-303F & TCTCGAAGCCAACGACGTTC & qRT-PCR (ruvB - CC_3236) \\
\hline ruvB-353R & GACGACAGGCGGTGGATCT & qRT-PCR (ruvB - CC_3236) \\
\hline ruvC-119F & TGATCACGCCTGACGAGAAG & qRT-PCR (ruvC-CC_3238) \\
\hline ruvC-172R & CGAACAGGTGCAGTAGCCG & qRT-PCR (ruvC-CC_3238) \\
\hline lexA5-6F & GTTTGTTCCGCGCTCCAG & qRT-PCR (lexA - CC_1902) \\
\hline lexA5-60R & CAGTTCGTGCTGCTTGCG & qRT-PCR (lexA - CC_1902) \\
\hline Rhofow & GTCGAGAACGCCAACTCCAT & qRT-PCR (rho-CC_3760) \\
\hline Rhorev & CGAGGGTCTTCAGGATCGC & qRT-PCR (rho-CC_3760) \\
\hline ctrAfowrt & CCGTCGTTCGAAGGGTCA & qRT-PCR (ctrA - CC_3035) \\
\hline ctrArevrt & ACGATGTCGCCGGTCTTG & qRT-PCR (ctrA - CC_3035) \\
\hline
\end{tabular}


ANEXO A: Oligonucleotídeos utilizados neste trabalho.

(Continuação)

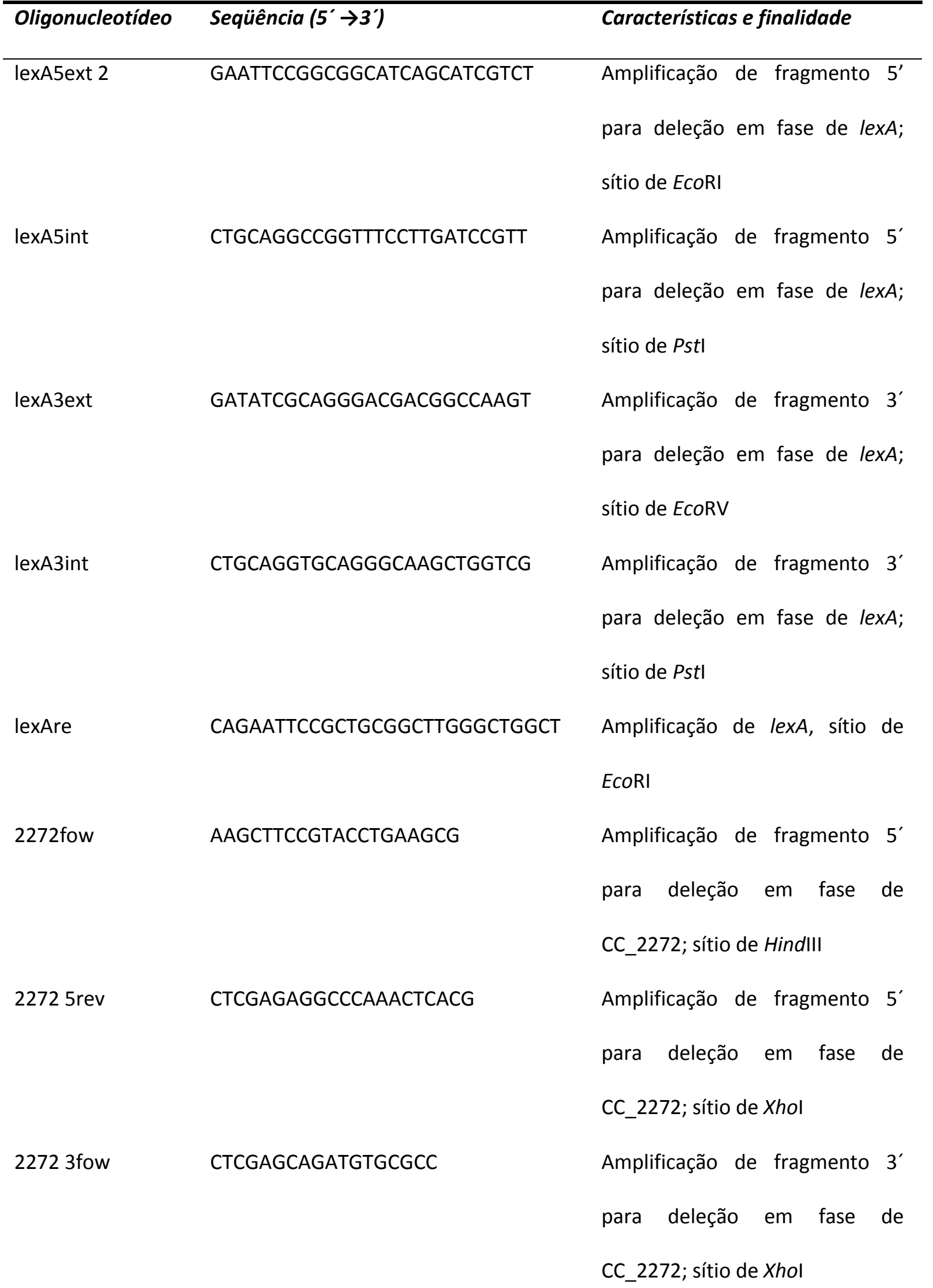


ANEXO A: Oligonucleotídeos utilizados neste trabalho.

(Continuação)

\begin{tabular}{|c|c|c|}
\hline Oligonucleotídeo & Seqüência $\left(5^{\prime} \rightarrow 3^{\prime}\right)$ & Características e finalidade \\
\hline 2272rev & GAATTCGGATGAGCTTCCAGC & $\begin{array}{l}\text { Amplificação de fragmento 3' para } \\
\text { deleção em fase de CC_2272; sítio de } \\
\text { EcoRI }\end{array}$ \\
\hline 3731 fow & AAGCTTGACCCGCGTGAAGGC & $\begin{array}{l}\text { Amplificação de CC_3731; sítio de } \\
\text { HindIII }\end{array}$ \\
\hline 3731rev & GAATTCCGCCCATGACAAGGG & $\begin{array}{l}\text { Amplificação de CC_3731; sítio de } \\
\text { EcoRI }\end{array}$ \\
\hline 3038delext & GAATTCGCCGGCTTCGGCCAGGGC & $\begin{array}{l}\text { Amplificação de fragmento } 5^{\prime} \text { para } \\
\text { deleção em fase de CC_3038- } \\
\text { CC_3037-CC_3036; sítio de EcoRI }\end{array}$ \\
\hline 3038delint & CTCGAGACGCAGATCGCCCGGCAG & $\begin{array}{l}\text { Amplificação de fragmento } 5^{\prime} \text { para } \\
\text { deleção em fase de CC_3038- } \\
\text { CC_3037-CC_3036; sítio de Xhol }\end{array}$ \\
\hline 3036delext & AAGCTTCTCGATCAACAGTACGCG & $\begin{array}{l}\text { Amplificação de fragmento 3' para } \\
\text { deleção em fase de CC_3038- } \\
\text { CC_3037-CC_3036; sítio de HindIII }\end{array}$ \\
\hline 3036delint & CTCGAGGTGGCCAAGCTGCGAGCG & $\begin{array}{l}\text { Amplificação de fragmento 3' para } \\
\text { deleção em fase de CC_3038- } \\
\text { CC_3037-CC_3036; sítio de Xhol }\end{array}$ \\
\hline 06275 ext2 & ACTAGTGCGCGCTCAGGTTGCATG & $\begin{array}{l}\text { Amplificação de fragmento } 5^{\prime} \text { para } \\
\text { deleção em fase de CC_0627; sítio de } \\
\text { Spel }\end{array}$ \\
\hline
\end{tabular}


ANEXO A: Oligonucleotídeos utilizados neste trabalho.

(Continuação)

\begin{tabular}{|c|c|c|}
\hline Oligonucleotídeo & Seqüência $\left(5^{\prime} \rightarrow 3^{\prime}\right)$ & Características e finalidade \\
\hline 0627 5int & TCTAGAGGCGGACATACCAAGCCC & $\begin{array}{l}\text { Amplificação de fragmento 5' para } \\
\text { deleção em fase de CC0627; sítio } \\
\text { de Xbal }\end{array}$ \\
\hline 0627 3int & TCTAGAGTCGCCTGCTGGTCG & $\begin{array}{l}\text { Amplificação de fragmento 3' para } \\
\text { deleção em fase de CC0627; sítio } \\
\text { de Xbal }\end{array}$ \\
\hline 06273 ext2 & GAATTCACGCGAAGGGTGTGC & $\begin{array}{l}\text { Amplificação de fragmento 3' para } \\
\text { deleção em fase de CC_0627; sítio } \\
\text { de EcoRI }\end{array}$ \\
\hline $24335 \mathrm{ext}$ & CTGCAGCGCACCTGAAGGCGT & $\begin{array}{l}\text { Amplificação de fragmento 5' para } \\
\text { deleção em fase de CC_2433; sítio } \\
\text { de Pstl }\end{array}$ \\
\hline $24335 \mathrm{int}$ & TCTAGAGGCCGGCGGTTCATT & $\begin{array}{l}\text { Amplificação de fragmento 5' para } \\
\text { deleção em fase de CC_2433; sítio } \\
\text { de Xbal }\end{array}$ \\
\hline $24333 e x t$ & GAATTCTTCCGCGACCTGCTG & $\begin{array}{l}\text { Amplificação de fragmento 3' para } \\
\text { deleção em fase de CC_2433; sítio } \\
\text { de EcoRI }\end{array}$ \\
\hline 2433 3int & TCTAGAGAGTGGCTGGCCCAC & $\begin{array}{l}\text { Amplificação de fragmento 3' para } \\
\text { deleção em fase de CC_2433; sítio } \\
\text { de Xbal }\end{array}$ \\
\hline imuArace1 & ACAGCGCGTCCTCCAG & $\begin{array}{l}\text { Oligonucleotídeo GSP1 para } 5^{\prime} \\
\text { Race de imuA }\end{array}$ \\
\hline
\end{tabular}


ANEXO A: Oligonucleotídeos utilizados neste trabalho.

(Conclusão)

\begin{tabular}{|c|c|c|}
\hline Oligonucleotídeo & Seqüência $\left(5^{\prime} \rightarrow 3^{\prime}\right)$ & Características e finalidade \\
\hline imuArace2 & AGCGACAGGGTTTCAG & $\begin{array}{l}\text { Oligonucleotídeo GSP2 para 5’ } \\
\text { Race de imuA }\end{array}$ \\
\hline imuArace3 & GCTGGGTGACAAAGGCGG & $\begin{array}{l}\text { Oligonucleotídeo GSP3 para 5' } \\
\text { Race de imuA }\end{array}$ \\
\hline 2272race1 & CAGGGCTTGCAGCTC & $\begin{array}{l}\text { Oligonucleotídeo GSP1 para 5' } \\
\text { Race de CC_2272 }\end{array}$ \\
\hline 2272race 2 & GCCAGCCGACCTTCTC & $\begin{array}{l}\text { Oligonucleotídeo GSP2 para 5' } \\
\text { Race de CC_2272 }\end{array}$ \\
\hline 2272 race 3 & CCAGATCCTCCCAGCTCT & $\begin{array}{l}\text { Oligonucleotídeo GSP3 para 5' } \\
\text { Race de CC_2272 }\end{array}$ \\
\hline p3213fo & GGTACCAACGTCGTCAGGTGCTC & $\begin{array}{l}\text { Oligonucleotídeo externo para } \\
\text { mutagênese sítio dirigida de } \\
\text { PimuA e clonagem }\end{array}$ \\
\hline p3213re & AAGCTTCCCGGAAAGCACCCGTC & $\begin{array}{l}\text { Oligonucleotídeo externo para } \\
\text { mutagênese sítio dirigida de } \\
\text { PimuA e clonagem }\end{array}$ \\
\hline PimuAmutfow & CAGAACAAAAGTGCGACATGGAGTTGGG & $\begin{array}{l}\text { Oligonucleotídeo para } \\
\text { mutagênese sítio dirigida de } \\
\text { PimuA }\end{array}$ \\
\hline PimuAmutrev & CCCAACTCCATGTCGCACTTTTGTTCTG & $\begin{array}{l}\text { Oligonucleotídeo para } \\
\text { mutagênese sítio dirigida de } \\
\text { PimuA }\end{array}$ \\
\hline
\end{tabular}




\title{
Characterization of the SOS Regulon of Caulobacter crescentus ${ }^{\nabla} \ddagger$
}

\author{
Raquel Paes da Rocha, Apuã César de Miranda Paquola, Marilis do Valle Marques, \\ Carlos Frederico Martins Menck, ${ }^{*}$ and Rodrigo S. Galhardo $\dagger$ \\ Department of Microbiology, Institute of Biomedical Sciences, São Paulo University, São Paulo, Brazil
}

Received 31 August 2007/Accepted 5 December 2007

\begin{abstract}
The SOS regulon is a paradigm of bacterial responses to DNA damage. A wide variety of bacterial species possess homologs of $\operatorname{lex} A$ and $\operatorname{rec} A$, the central players in the regulation of the SOS circuit. Nevertheless, the genes actually regulated by the SOS have been determined only experimentally in a few bacterial species. In this work, we describe 37 genes regulated in a LexA-dependent manner in the alphaproteobacterium Caulobacter crescentus. In agreement with previous results, we have found that the direct repeat GTTCN GTTC is $_{7}$ the SOS operator of $C$. crescentus, which was confirmed by site-directed mutagenesis studies of the imu $A$ promoter. Several potential promoter regions containing the SOS operator were identified in the genome, and the expression of the corresponding genes was analyzed for both the wild type and the lexA strain, demonstrating that the vast majority of these genes are indeed SOS regulated. Interestingly, many of these genes encode proteins with unknown functions, revealing the potential of this approach for the discovery of novel genes involved in cellular responses to DNA damage in prokaryotes, and illustrating the diversity of SOSregulated genes among different bacterial species.
\end{abstract}

The prototypical cellular response to DNA damage in prokaryotes is the SOS response. Best characterized in Escherichia coli, it can be viewed as a global stress response system, which controls the expression of several genes in response to a wide variety of environmental challenges (reviewed in reference 24). In a noninduced state, the genes belonging to the SOS network are repressed by the LexA protein, which binds in a dimeric conformation to an operator located in the regulatory region of target genes, termed the SOS box. The SOS regulon is activated in response to single-stranded DNA regions, which can be a result of DNA replication inhibition or the processing of broken ends in this molecule (53). The RecA protein is able to associate with such regions, acquiring an activated conformation $\left(\mathrm{Rec}^{*}\right)$. This active form can act as a coprotease in the cleavage of the $\mathrm{Ala}^{84}$-Gly ${ }^{85}$ bond of the LexA repressor (reviewed in reference 63). This cleavage, similar to that mediated by serine proteases, prevents LexA from binding to the SOS operator sequences. Once freed from the repression imposed by LexA, the genes belonging to the SOS regulon can be transcribed, helping the cell to manage the DNA damage. After the DNA lesions have been repaired, the RecA protein activation ceases, and LexA can regain the transcriptional control of the SOS genes. Besides contributing to cell survival after DNA injury, the SOS response has also been proposed to play an important role in bacterial evolution, by up-regulating mutation rates in growth-inhibiting environments $(11,36,40)$.

The SOS response is extremely important for prokaryotic cells, and therefore, it is widespread among the Bacteria. How-

\footnotetext{
* Corresponding author. Mailing address: Department of Microbiology, ICB, USP, Av. Prof. Lineu Prestes, 1374, 05508-900 São Paulo, Brazil. Phone: 55113091 7499. Fax: 55113091 7354. E-mail: cfmmenck@usp.br.

\$ Supplemental material for this article may be found at http://jb .asm.org/.

$\dagger$ Present address: Department of Molecular and Human Genetics,

Baylor College of Medicine, Houston, TX.

${ }^{\nabla}$ Published ahead of print on 14 December 2007.
}

ever, two interesting features have been demonstrated to be highly variable among different bacterial species: the sequence recognized by LexA as the SOS operator and the actual set of genes subject to LexA control $(2,11,18)$. The structure of the regulon can vary depending on the organism, but still, a canonical set of genes has been proposed to be LexA regulated in all Proteobacteria studied to date. It is comprised of lex $A$, recA, ssb, uvrA, and ruvCAB (19).

Several different strategies have been used to identify the genes directly regulated by RecA-LexA. Microarray technology has extensively been used for $E$. coli $(13,31,48)$ to compare the level of induction in noninduced and induced states (UV-mediated DNA damage, lex $A$ Ind $^{-}$versus lex $A$ Def strains, and mitomycin C-mediated DNA damage). Another successful strategy has been the in silico identification of LexAregulated genes based on algorithms devoted to the identification of the SOS operator and/or the search of the genome sequence for promoters containing the conserved motif. This strategy helped to expand the array of $E$. coli genes known to be SOS regulated $(21,33)$. The use of this type of approach has prompted the in silico characterization of the SOS regulatory circuit in several bacterial species $(16,18,19)$ and is constantly expanding our knowledge about the SOS response in models other than E. coli. Nevertheless, most of the in silico analyses of SOS regulons done to date lack extensive biological validation, making the assumptions of gene content less robust and missing important information about differential levels of SOS induction for different genes.

The characterization of the SOS response in other bacteria led to the conclusion that the E. coli SOS genes cannot be assumed to be universally LexA regulated in all bacterial species. In the deltaproteobacteria Bdellovibrio bacteriovorus, for example, some genes considered to be part of the core of the proteobacterial SOS genes $(\operatorname{rec} A, u v r A, \operatorname{ruvCAB}$, and $s s b)$ are not repressed by the LexA protein (9). Likewise, dissection of the SOS regulon in other species may show different genes involved in the DNA damage response which are not present 
TABLE 1 . Bacterial strains and plasmids

\begin{tabular}{|c|c|c|}
\hline Strain or plasmid & Description & Reference or source \\
\hline \multicolumn{3}{|l|}{ Strains } \\
\hline NA1000 & Parental strain, C. crescentus CB15 derivative & 20 \\
\hline $\operatorname{lex} A$ & NA1000 $(\Delta l e x A)$ & This study \\
\hline \multicolumn{3}{|l|}{ Plasmids } \\
\hline pGEM-T Easy & Cloning vector & Promega \\
\hline pNPTS138 & pNPTS129 derivative, oriT $\operatorname{sacB} \mathrm{Kan}^{\mathrm{r}}$ & 61 \\
\hline pMR20 & Broad-host-range, low copy vector, Tet ${ }^{\mathrm{r}}$ & 52 \\
\hline pRKlacZ290 & pRK2-derived vector with a promoterless $l a c Z$ gene, Tet $^{\mathrm{r}}$ & 26 \\
\hline pP3213 & imuA promoter cloned in the pLacZ290 vector & 25 \\
\hline pP3213Oc & $\begin{array}{l}\text { imu } A \text { promoter fragment containing the } \mathrm{O}^{\mathrm{c}} \text { mutation in the SOS operator, } \\
\text { cloned in the pLacZ290 vector }\end{array}$ & This study \\
\hline pPLEXA & lexA promoter cloned in the pRKlacZ290 & This study \\
\hline pLEXDEL & $\begin{array}{l}\text { In-frame deletion of the lex } A \text { gene and flanking regions cloned in } \\
\text { pNPTS138 }\end{array}$ & This study \\
\hline pMRLEXA & $\operatorname{lex} A$ gene plus promoter region cloned in the pMR20 vector & This study \\
\hline
\end{tabular}

in the E. coli genome. Recently, we have demonstrated that a three-gene operon encoding a hypothetical protein (ImuA), a protein similar to members of the $\mathrm{Y}$ family of DNA polymerases (ImuB), and a second copy of dnaE (DnaE2) is responsible for the DNA damage-inducible mutagenesis in $\mathrm{Cau}$ lobacter crescentus, a function performed by the UmuDC proteins in E. coli. (25). This SOS-regulated operon is widespread in Bacteria (1) and was recently shown to be part of the SOS-mediated response to the antibiotic ciprofloxacin in Pseudomonas aeruginosa (11), demonstrating the relevance of expanding the knowledge about the SOS regulatory circuit in other models.

In the present work, we report the characterization of the SOS regulon of Caulobacter crescentus. We have performed a computational screening for the LexA binding motif in the whole genome of this organism and found that the SOS operator is in good agreement with the direct repeat $\mathrm{GTTCN}_{7} \mathrm{G}$ TTC, the same repeat suggested previously to be universal among alphaproteobacteria (19). We have confirmed the functionality of this operator with site-directed mutagenesis experiments of the LexA-regulated imuA promoter and by mapping its position relative to the actual transcriptional start site of two SOS genes. The expression of several genes identified in silico as potentially SOS regulated, by means of the presence of the operator in their putative regulatory regions, was investigated. The assays were performed by comparing the levels of expression of the selected genes in a $C$. crescentus lex $A$ strain and its parental counterpart. We have been able to identify some unreported genes that are part of the SOS regulon, as well as confirm the inducibility of previously described LexA-regulated genes.

\section{MATERIALS AND METHODS}

Bacterial strains, plasmids, and primers. The bacterial strains and plasmids used in this study are shown in Table 1; for a list of all primers cited in this article, see Table S1 in the supplemental material. The $C$. crescentus strains were grown in PYE medium (17) at $30^{\circ} \mathrm{C}$ with constant shaking. Plasmids were introduced into $C$. crescentus by conjugation with $E$. coli strain S17-1. When appropriate, the culture medium was supplemented with kanamycin $(50 \mu \mathrm{g} / \mathrm{ml})$, nalidixic acid $(25$ $\mu \mathrm{g} / \mathrm{ml})$, spectinomycin $(50 \mu \mathrm{g} / \mathrm{ml})$, or tetracycline $(2 \mu \mathrm{g} / \mathrm{ml})$. E. coli strain DH10B (Invitrogen, CA) was used for cloning purposes. The $E$. coli strain was grown at $37^{\circ} \mathrm{C}$ in LB medium supplemented with ampicillin $(100 \mu \mathrm{g} / \mathrm{ml})$, kanamycin (50 $\mu \mathrm{g} / \mathrm{ml})$, or tetracycline $(15 \mu \mathrm{g} / \mathrm{ml})$, when necessary.
The construction of gene-targeting plasmids was performed with PCR products amplified with the appropriate primers. These products were cloned in the pGEM-T Easy vector (Promega) and sequenced to ensure sequence integrity. For the disruption of $l e x A$, fragments were amplified with primers lexA5ext 2 and lexA5int and primers lexA3int and lexA3ext and fused in the pNPTS138 vector by use of the restriction sites introduced in the oligonucleotides. This strategy generated a 1,824-bp fragment containing the first $96 \mathrm{bp}$ fused to the last $42 \mathrm{bp}$ of lexA plus flanking regions, leading to a $600-\mathrm{bp}$ in-frame deletion of $l e x A$. The resulting plasmid, pLEXDEL, was introduced into $C$. crescentus NA1000 by conjugation with $E$. coli S17-1. Genetic disruption was achieved by two consecutive recombination events. The vector contains the $n p t I$ gene, conferring kanamycin resistance, and the $s a c B$ gene, conferring sucrose sensitivity. First, Kan conjugants of $C$. crescentus were selected in the screening for plasmid integration. The loss of the plasmid after the second recombination was selected in PYE media containing $3 \%$ sucrose. Strains generated in this way were analyzed by diagnostic PCR to confirm gene disruptions.

In order to promote complementation of the phenotypes of the lexA strain, a full-length gene, including the promoter region, was amplified with the lexA5ext2 and lexAre oligonucleotides and cloned in the low-copy-number pMR20 vector, using the restriction sites introduced in the primers. The resulting fragment contains $1,481 \mathrm{bp}$ and includes the whole lexA gene plus $597 \mathrm{bp}$ before the transcription initiation codon and 146 bp after the gene stop codon.

Growth determination experiments. Overnight cultures of the C. crescentus strains were diluted to an initial optical density at $600 \mathrm{~nm}\left(\mathrm{OD}_{600}\right)$ of 0.1 in PYE medium and incubated with constant shaking at $30^{\circ} \mathrm{C}$. At each indicated time interval, two aliquots of the cultures were removed. The first one was utilized for the optical density determination, and the other one was subjected to serial dilutions and plated on solid PYE medium for CFU counting, which was carried out 2 days after the plating.

In silico analysis. $\mathrm{Ab}$ initio searches for overrepresented DNA motifs were done with the Gibbs Motif Sampler program (60) in regions from -250 bp to $+50 \mathrm{bp}$ of the predicted start codons of the current set of known LexA-regulated genes in C. crescentus. A motif width of 19 bp was used as a parameter in these searches to account for the previously reported 15-bp alphaproteobacterial LexA binding motif (19) and to allow for additional conserved positions in its vicinity. A position weight matrix derived from the most abundant motif found in each search was used to score candidate LexA binding sites. This matrix is given by $m_{b i}=-\ln \left(f_{b i} / p_{b}\right)$, where $f_{b i}$ is the frequency of the base $b$ in position $i$ of the motif and $p_{b}$ is the frequency of base $b$ in the whole genome (55). Genome sequence and gene annotations were obtained from the TIGR database (http: //www.tigr.org/cmr/).

Real-time analysis of gene expression. The relative expression levels of the genes belonging to the SOS regulon in $C$. crescentus were determined by quantitative reverse transcription (RT)-PCR experiments comparing the level of expression in the wild-type strain with that of the strain containing the lex $A$ gene disruption. RNA from exponentially growing cells was extracted with Trizol reagent (Invitrogen) and treated with DNase I to eliminate contaminant DNA. An aliquot of $2 \mu \mathrm{g}$ of RNA pretreated with DNase I was used as a template for total cDNA synthesis in $20-\mu l$ reaction mixtures with random hexamers by use of the Superscript First-Strand synthesis system for RT-PCR (Invitrogen). For 
quantitative PCR, an amount of cDNA corresponding to $25 \mathrm{ng}$ of input RNA was used in each reaction. Reactions were performed with the Sybr green PCR master mix (Applied Biosystems) and analyzed in the ABI 7500 real-time system. Relative expression levels were calculated as described previously (47), using the rho gene as an endogenous control.

Site-directed mutagenesis of the imu $A$ promoter and $\beta$-galactosidase assays. PCR-mediated mutagenesis of the imuA promoter was accomplished using primers with the desired mutation. The introduced mutations led to two base substitutions in PimuA. Two complementary mutagenic primers (see Table S1 in the supplemental material) were used with external primers to amplify fragments of PimuA containing the desired mutation. Both fragments were used in a further reaction with only the external primers to generate full-length fragments containing the mutation. All the PCRs were carried out with the high-fidelity Pfx enzyme (Invitrogen), using the cloned PimuA (pP3213) (25) as a template. After the full-length mutant promoter fragment was produced, it was subcloned in the pGEM-T Easy vector (Promega) and sequenced to ensure that the correct mutation was introduced and that no additional mutations were generated during amplification. The fragment was then subcloned in the pRKLacZ290 plasmid to create a transcriptional fusion with lacZ. Measurements of promoter activity with lac $Z$ transcriptional fusions were performed as described previously (25), both before and $60 \mathrm{~min}$ after UV irradiation in exponentially growing cells in PYE medium.

UV irradiation. All the cell irradiations were carried out in rich medium (PYE). A germicidal lamp that preferentially emits UVC (254 nm, dose rate of $3.26 \mathrm{~J} / \mathrm{m}^{2} / \mathrm{s}$ ) was used. The UV dose was monitored by a VLX $3 \mathrm{~W}$ radiometer with a CX-254 monochromatic sensor (Vilber Lourmat, Marne-la-Vallée, France). A UVC dose of $45 \mathrm{~J} / \mathrm{m}^{2}$ was used in the $\beta$-galactosidase assays described above. This dose was shown previously to yield about $6,000 \beta$-galactosidase units in a $l a c Z$ gene fusion with the $i m u A$ gene promoter in a wild-type background (25).

Determination of transcriptional start sites by $5^{\prime}$ RACE experiments. RNA was extracted from exponentially growing lexA cells with the Trizol reagent. 5' rapid amplification of cDNA ends (RACE) experiments using the $5^{\prime}$ RACE system (Invitrogen) were conducted as follows: three primers (GSP1 to GSP3) were designed for each gene. GSP1 was used for gene-specific cDNA synthesis. A poly $(\mathrm{T})$ tail was added to the $5^{\prime}$ end of the cDNA with terminal deoxynucleotidyl transferase (Tdt). The tailing reactions were used as templates for PCR with the primers GSP2 and 3' RACE. A nested PCR was performed to increase specificity, using primers GSP3 and AUAP, and the amplification products were cloned in the pGEM-T Easy vector (Promega). Nine clones were sequenced for the CC $22725^{\prime}$ RACE reactions, and 10 for the imuA 5' RACE reactions. The transcriptional start site was then identified as the base adjacent to the poly(T) tail represented more among the sequenced clones, which meant $70 \%$ of the clones for $i m u A$ and $66.7 \%$ of the clones for CC_2272.

\section{RESULTS}

Construction of a lexA-deficient strain of Caulobacter crescentus. The open reading frame (ORF) CC 1902 was annotated in the $C$. crescentus genome as lexA. BLAST analysis using the E. coli LexA protein as a probe showed the gene product of this ORF as the single significant hit, confirming its annotation (E value of 8.9e-25). A strain containing an internal deletion of 600 base pairs in the lex $A$ gene was constructed by double recombination (61). The deletion of this gene disruption caused a severe growth defect in the lexA strain in rich medium at $30^{\circ} \mathrm{C}$. Its growth rate was approximately half of that observed for the wild-type NA1000 strain (generation time of about $240 \mathrm{~min}$, contrasted with the $120 \mathrm{~min}$ observed for NA1000) (Fig. 1A). A decrease in cell viability in the lexA strain was observed compared to the wild-type strain (Fig. 1B); although both cultures started from the same $\mathrm{OD}_{600}$, the lexA strain always exhibited fewer CFU per ml. When observed under light microscopy, the cells exhibited a filamentous aspect, as expected for lex $A$ null strains (Fig. $1 \mathrm{C}$ and D). In $E$. coli, an SOS-induced filamentation is mediated by the sulA gene product, which inhibits cell division by blocking FtsZ ring formation $(4,54)$. lexA knockouts are not viable in $E$. coli, unless a sulA mutation is present. As mentioned above, although viable, the $C$. crescentus lex $A$ mutant presents a severe filamentous phenotype. Interestingly, sul $A$ homologs are not present in $C$. crescentus, as noted previously (25), indicating that a distinct mechanism of a divisional checkpoint might be responsible for the SOS-mediated cell division suppression in this organism. Although this mutant strain could have accumulated suppressor mutations which might have allowed its survival, we were able to consistently obtain independent lex $A$ knockouts, suggesting that this gene is not essential in $C$. crescentus. The filamentous phenotype of the lexA strain is complemented by a low copy vector expressing the wild-type lex $A$ gene (Fig. 1E), indicating that no additional mutations are responsible for this phenotype of the lex $A$ strain.

In silico determination of the LexA operator and identification of the SOS regulon of $\boldsymbol{C}$. crescentus. We adopted an iterative approach, combining the in silico prediction of LexA binding sites and gene expression measurements to successively augment the set of known LexA-regulated genes and improve the current LexA binding site model. Each iteration consisted of the following steps. (i) The promoter regions of the current set of known LexA-regulated genes are used in an ab initio search for overrepresented DNA motifs with the Gibbs Motif Sampler program (60). The set of genes used in the first iteration consisted of $\operatorname{lex} A, \operatorname{rec} A$, and $\operatorname{rec} N$, whose orthologs are part of the SOS regulon in several different bacterial species, and also imuA and $u v r A$, which are known to be LexA regulated in $C$. crescentus (25). (ii) The positionspecific nucleotide frequency matrix corresponding to the most abundant motif found in step 1 is taken as the current LexA box model and is used to scan the $C$. crescentus genome sequence in search of candidate binding sites. (iii) The expression levels of genes immediately downstream of high-score sites are measured in the lex $A$ and wild-type strains by realtime PCR experiments. Genes whose expression levels changed at least twofold in the lex $A$ strain are added to the set of LexA-regulated genes and are used in step 1 of the next iteration.

After a number of iterations of the procedure described above, we obtained the set of genes regulated by LexA shown in Table 2. The promoter regions of the 32 genes that have a twofold expression change in the lex $A$ strain and that are in the first position of the respective putative operon were used in the construction of the final LexA binding site model, whose logo (14) is shown in Fig. 2. See Fig. S1 in the supplemental material for the genomic regions comprising the highest scoring putative LexA sites, obtained in a whole-genome scan of the final box model.

As shown in Fig. 2, the LexA binding site model is in good agreement with previously described alphaproteobacterial

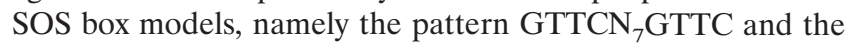
matrix model obtained previously (19). However, due to the larger number of sequences used in model construction, it was possible to detect new positions in the box with a partial degree of conservation, as in the vicinity of each GTTC block shown in Fig. 2. Such positions may also contribute to the binding of LexA.

Gene expression analysis of the SOS regulon. To ascertain which of the genes identified in silico as potentially belonging to the SOS regulon were actually regulated by LexA in vivo, we 

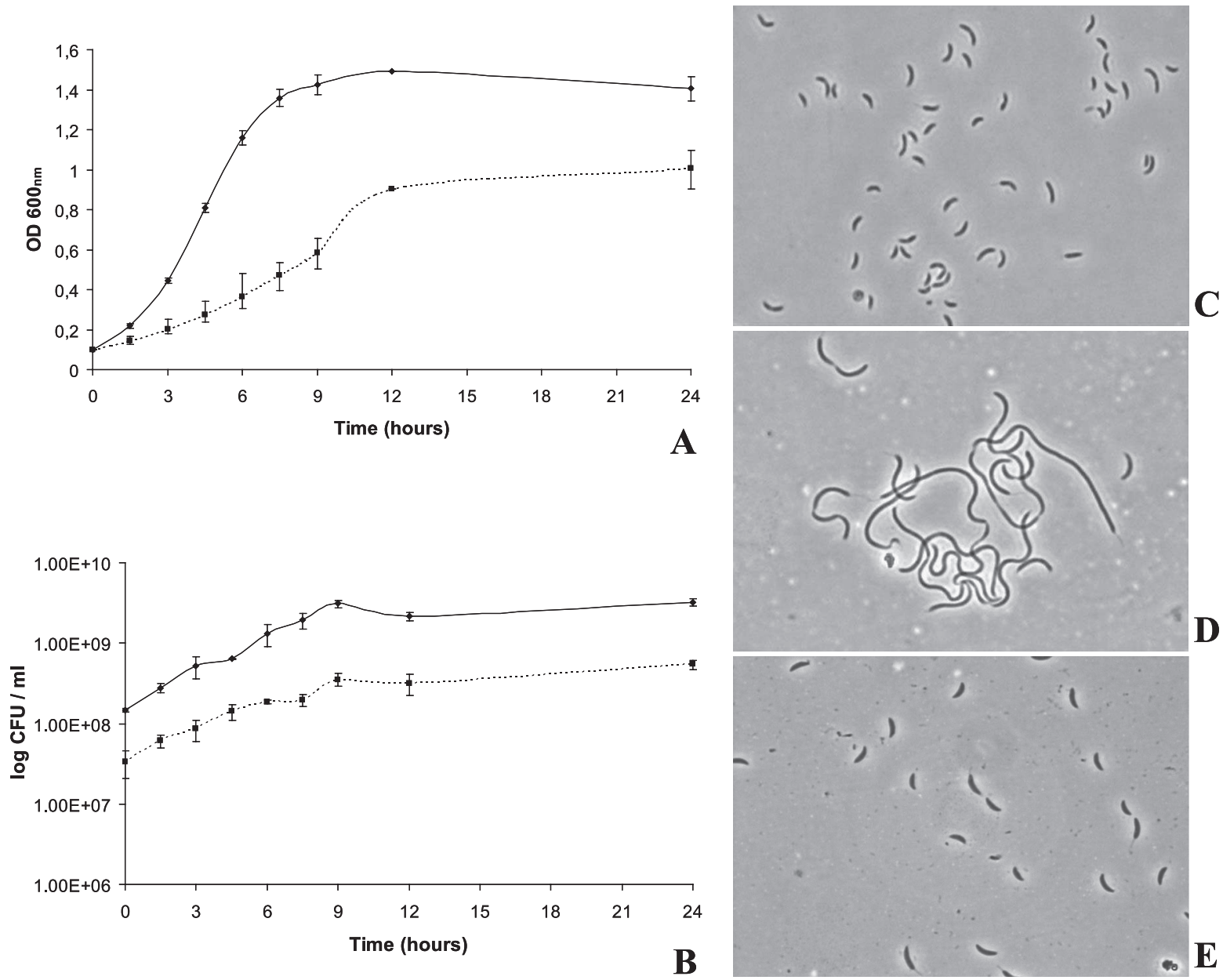

FIG. 1. Phenotypic characterization of the C. crescentus lexA strain. (A and B) Growth curve of the wild-type NA1000 and lexA strains. Cells were grown in PYE medium at $30^{\circ} \mathrm{C}$ and monitored for up to $9 \mathrm{~h}\left(\mathrm{CFU}\right.$ counting) and $24 \mathrm{~h}\left(\mathrm{OD}_{600}\right)$. $\mathrm{OD}_{600}$ determination $(\mathrm{A})$ and $\mathrm{CFU}$ determination (B). Error bars indicate standard errors. Solid lines, wild-type NA1000 strain; dotted lines, the lexA strain. (C to E) Light microscopy of $C$. crescentus strains using a $100 \times$ objective. Wild-type NA1000 strain (C), the lexA strain (D), and the lexA strain after genotypic complementation with a low-copy-number vector containing the wild-type allele of lexA (E).

conducted quantitative RT-PCR assays during each of the iteration steps. The assays were performed by measuring the relative expression levels of the selected genes in the lex $A$ null strain versus the wild-type strain. We used as the endogenous control the rho gene, which encodes the transcription terminator Rho and is not induced in a LexA-dependent fashion, as determined by $\beta$-galactosidase assays (data not shown).

We performed the quantitative RT-PCR assays for 44 genes (Table 2). Among these, there were four putative operons, for which we tested all the genes possibly cotranscribed (CC 1926CC_1927, CC_2332-CC_2333, CC_2879-CC_2880-CC_2881, and CC_3238-CC_3237-CC_3236, the ruvCAB operon). On the other hand, when an SOS operator was found in the noncoding region between two divergently transcribed genes, we performed the assay for both of them in order to establish if the same box could repress both promoters. This was the case for genes CC_1086 and CC_1087, CC_1531 and CC_1532, CC_1927 and CC_1928, CC_2589 and CC_2590, CC_2878.1 and CC_2879, CC__3038 and CC_3039, and CC_0382 and CC_ 0383 (Table 2; see Fig. S1 in the supplemental material).
Among the divergently transcribed genes, we found that CC 3039 and the putative operon CC 3036-CC 3037CC_3038, CC_1531 and CC_1532, and CC_0382 and CC_- 0383 were induced in a lex $A$ null background. Some of the putative operons (CC 2332-CC 2333, CC 2879-CC 2880, CC 3036CC_3037-CC_3038, and the ruvCAB operon) had similar variations of transcriptional levels, supporting the idea that they are arranged in operons that are part of the SOS regulon. In other cases, some of the putative operons presented clearly different levels of transcript (CC 1926 and CC 1927; CC 2879 and CC_2881), suggesting that they are not transcribè as operons.

In total, of the 44 genes tested, 35 showed increased expression in the lexA strain (Table 2), exhibiting at least twofold increased expression in the lex $A$ strain compared to the wild type. Among them, there were some genes known to be part of the canonical SOS response in other proteobacteria, such as recA (CC_1087), lexA (CC_1902), uvrA (CC_2590), ssb (CC_1468), and recN (CC_1983). The ruvCAB operon was proposed to be part of the SOS regulon in all alphaproteobac- 
TABLE 2. Genes identified by in silico analyses as belonging to the SOS regulon of Caulobacter crescentus and comparison of in vivo expression of these genes in the $\operatorname{lex} A$ and wild-type strains

\begin{tabular}{|c|c|c|c|c|c|c|}
\hline $\mathrm{ORF}^{c}$ & Gene name/annotation & Box or description & Strand $^{a}$ & $\begin{array}{c}\text { Box } \\
\text { score }\end{array}$ & $\begin{array}{c}\text { Box } \\
\text { position }^{b}\end{array}$ & $\begin{array}{c}\text { Relative expression level } \\
\text { (lex } A \text { mutant/wild-type) }\end{array}$ \\
\hline CC_1902* & $\operatorname{lex} A$ & AATGTTCTCCTGGTGTTCC & - & 14.3 & -51 & $43.2 \pm 9.3$ \\
\hline CC_-0627* & Hypothetical protein & AAAGTTCGCGTTATGTTCT & - & 18.8 & -9 & $40.3 \pm 11.8$ \\
\hline $\mathrm{CC}_{-}^{-} 3467^{*}$ & $\begin{array}{l}\text { Conserved hypothetical } \\
\text { protein }\end{array}$ & CATGTTCCAGCTTTGTTCG & - & 13.6 & -20 & $37.5 \pm 10.5$ \\
\hline CC_3518* & $\begin{array}{l}\text { Conserved hypothetical } \\
\text { protein }\end{array}$ & GATGTTCATGTATTGTTCT & + & 18.8 & -3 & $27.4 \pm 4.8$ \\
\hline CC_2332* & $\begin{array}{l}\text { Conserved hypothetical } \\
\text { protein }\end{array}$ & ATCGTTCTTGATTTGTTCT & - & 18.7 & -13 & $18.8 \pm 6.8$ \\
\hline CC_2333 & $\begin{array}{l}\text { Uracil DNA } \\
\text { glycosylase-related } \\
\text { protein }\end{array}$ & Putative operon with CC_2332 & & & & $8.3 \pm 1.2$ \\
\hline \multirow[t]{3}{*}{ CC_1926 } & dnaE/DNA polymerase & CATATTCCGGTTTTGTTCT & - & 16.4 & -165 & \multirow[t]{3}{*}{$1.6 \pm 0.6$} \\
\hline & \multirow[t]{2}{*}{ III, alpha subunit } & AGATTTCTTGTTTTGTTCC & - & 11.4 & -181 & \\
\hline & & TCTGTTCACAAGATGTTCC & - & 11.1 & -147 & \\
\hline CC_1927* & Hypothetical protein & Putative operon with CC_1926 & & & & $17.7 \pm 6.2$ \\
\hline CC_-3213* & $\begin{array}{l}\text { imu } A \text { /inducible } \\
\text { mutagenesis protein } \\
\mathrm{A} \text {; in operon with } \\
\text { ImuB, a Y family } \\
\text { polymerase, and } \\
\text { DnaE2, a C family } \\
\text { DNA polymerase }\end{array}$ & CATGTTCCACTTTTGT̄TCT & - & 17.9 & -73 & $16.2 \pm 4.7$ \\
\hline CC_2272* & $\begin{array}{l}\text { Endonuclease III family } \\
\text { protein }\end{array}$ & AATGTTCTTGTTATGTTCT & + & 23.2 & -26 & $14.7 \pm 3.1$ \\
\hline CC_3424* & $\begin{array}{l}\text { Conserved hypothetical } \\
\text { protein }\end{array}$ & AATGTTCCTGAATTGTTCT & - & 20.7 & -26 & $13.62 \pm 5.5$ \\
\hline CC_1330* & $\begin{array}{l}\text { Radical SAM domain } \\
\text { protein }\end{array}$ & TATGTTCTTGTTATGTTCG & + & 20.6 & -33 & $11.7 \pm 3$ \\
\hline CC_1054* & Hypothetical protein & TTTGTTCTCGGCTTGTTCT & + & 16.3 & -3 & $11.3 \pm 5.5$ \\
\hline CC_-2040* & $\begin{array}{l}\text { ATP-dependent RNA } \\
\text { helicase, } \\
\text { DEAD/DEAH family }\end{array}$ & CATGTTCCCTTTCTGTTTC & - & 14.0 & -24 & $9.1 \pm 3.4$ \\
\hline CC_1087* & $\begin{array}{l}r e c A / \mathrm{DNA} \\
\text { recombination } \\
\text { protein } \mathrm{A}\end{array}$ & CATGTTCGCAAGATGTTCC & - & 15.5 & -114 & $9.0 \pm 1.5$ \\
\hline CC_2879* & Hypothetical protein & CATGTTCTGACTATGTTCC & - & 14.3 & 56 & $8.0 \pm 1.6$ \\
\hline CC_-2880* & Hypothetical protein & Putative operon with CC_2879 & & & & $9.74 \pm 3.7$ \\
\hline CC_2881 & $\begin{array}{l}\text { uvrC/exinuclease } \mathrm{ABC} \\
\text { subunit } \mathrm{C}\end{array}$ & Putative operon with $\mathrm{CC}_{-} 2879$ & & & & $1.7 \pm 0.3$ \\
\hline CC_3038* & $\begin{array}{l}\text { Conserved hypothetical } \\
\text { protein }\end{array}$ & AATGTTCCTATAATGTTCT & + & 21.5 & -160 & $5.3 \pm 0.8$ \\
\hline CC_3037 & $\begin{array}{l}\text { Conserved hypothetical } \\
\text { protein }\end{array}$ & Putative operon with CC_3038 & & & & $7.7 \pm 1.9$ \\
\hline CC_3036 & Hypothetical protein & Putative operon with CC_3038 & & & & $7.3 \pm 1.2$ \\
\hline CC_-3039* & Hypothetical protein & AATGTTCCTATAATGT̄TCT & - & 21.5 & -159 & $4.4 \pm 0.2$ \\
\hline CC_-3356* & Hypothetical protein & CATGTTCTCGTATTGTTCG & - & 18.1 & -52 & $6.3 \pm 2.5$ \\
\hline $\mathrm{CC}_{-}^{-} 1531^{*}$ & Hypothetical protein & ATTGTTCTTGATATGTTCC & + & 20.2 & -31 & $5.9 \pm 1.1$ \\
\hline & & TATGTTCCAACTTCGTTTG & & 11.3 & -20 & \\
\hline CC_1983* & $\operatorname{recN}$ & GATGATCCCGTTTCGTTCC & + & 11.9 & -56 & $5.6 \pm 1.6$ \\
\hline CC_0140* & $\begin{array}{l}\text { com } M / \text { competence } \\
\text { protein ComM }\end{array}$ & AACGTTCGTTTTTCGTTCT & + & 15.7 & -72 & $4.7 \pm 0.1$ \\
\hline CC_0383* & Hypothetical protein & TATGTTCCTGAAAAGTTCT & - & 18.5 & -14 & $5.0 \pm 2.7$ \\
\hline $\mathrm{CC}_{-}^{-} 3238^{*}$ & ruvC & CGCGTTCATCATGTGTTCT & - & 10.4 & 2 & $5.1 \pm 1.9$ \\
\hline $\mathrm{CC}_{-}^{-} 3237$ & $\operatorname{ruv} A$ & Putative operon with CC_3238 & & & & $5.0 \pm 0.8$ \\
\hline $\mathrm{CC}_{-}^{-} 3236$ & $\operatorname{ruvB}$ & Putative operon with $\mathrm{CC}_{-} 3238$ & & & & $3.4 \pm 0.4$ \\
\hline $\mathrm{CC}_{-}^{-} 3225^{*}$ & $\begin{array}{l}\text { Sensory box sensor } \\
\text { histidine } \\
\text { kinase/response } \\
\text { regulator }\end{array}$ & TTTGTTCGCCAGATTT̄TTT & + & 12.9 & 8 & $4.8 \pm 1.9$ \\
\hline CC_0382* & $\begin{array}{l}\text { tag/DNA-methyladenine } \\
\text { glycosylase I }\end{array}$ & TATGTTCCTGAAAAGTTCT & + & 18.5 & -44 & $3.4 \pm 1.2$ \\
\hline CC_2590* & $u v r A$ /exinuclease $\mathrm{ABC}$ & TTTGTTCGCATCTTGTTCT & + & 17.7 & -87 & $3.5 \pm 1.0$ \\
\hline & subunit A & CTTGTTCTCGCGACGTTCG & - & 10.6 & -268 & \\
\hline CC_1532* & Conserved hypothetical & ATTGTTCTTGATATGTTCC & - & 20.2 & +32 & $3.1 \pm 0.7$ \\
\hline & protein & TATGTTCCAACTTCGTTTG & & 11.3 & +21 & \\
\hline
\end{tabular}


TABLE 2-Continued

\begin{tabular}{|c|c|c|c|c|c|c|}
\hline $\mathrm{ORF}^{c}$ & Gene name/annotation & Box or description & Strand $^{a}$ & $\begin{array}{l}\text { Box } \\
\text { score }\end{array}$ & $\begin{array}{c}\text { Box } \\
\text { position }^{b}\end{array}$ & $\begin{array}{l}\text { Relative expression level } \\
\text { (lexA mutant/wild-type) }\end{array}$ \\
\hline CC_3515* & $\begin{array}{l}\text { Conserved hypothetical } \\
\text { protein }\end{array}$ & AGAGTTCGCATTATGTTCT & + & 15.7 & -79 & $3.1 \pm 0.6$ \\
\hline CC_1468* & $\begin{array}{l}s s b / \text { single-stranded } \\
\text { binding protein }\end{array}$ & TTTGTTCTCATAACGTTCT & - & 18.6 & -93 & $2.1 \pm 1.0$ \\
\hline CC_3130* & $\begin{array}{l}\text { Glutamine synthetase } \\
\text { family protein }\end{array}$ & $\begin{array}{l}\text { TTTGTTCTCGAAAGGTTTC } \\
\text { GTTTTTCCGGATTTGTTCT }\end{array}$ & $\begin{array}{l}- \\
-\end{array}$ & $\begin{array}{l}14.4 \\
11.7\end{array}$ & $\begin{array}{l}-52 \\
-41\end{array}$ & $2.1 \pm 0.9$ \\
\hline CC_2878.1 & $\begin{array}{l}\text { Conserved hypothetical } \\
\text { protein }\end{array}$ & CATGTTCTGACTATGTTCC & + & 14.3 & -55 & $1.4 \pm 0.7$ \\
\hline CC_2589 & Hypothetical protein & $\begin{array}{l}\text { TTTGTTCGCATCTTGTTCT } \\
\text { CTTGTTCTCGCGACGTTCG }\end{array}$ & $\begin{array}{l}- \\
+\end{array}$ & $\begin{array}{l}17.7 \\
10.6\end{array}$ & $\begin{array}{l}-154 \\
+27\end{array}$ & $0.9 \pm 0.3$ \\
\hline CC_1928 & $\begin{array}{l}\text { Inosine-uridine- } \\
\text { preferring nucleoside } \\
\text { hydrolase }\end{array}$ & $\begin{array}{l}\text { CATATTCCGGTTTTGTTCT } \\
\text { AGATTTCTTGTTTTGTTCC } \\
\text { TCTGTTCACAAGATGTTCC }\end{array}$ & $\begin{array}{l}+ \\
+ \\
+\end{array}$ & $\begin{array}{l}16.4 \\
11.4 \\
11.1\end{array}$ & $\begin{array}{l}-126 \\
-110 \\
-144\end{array}$ & $0.8 \pm 0.2$ \\
\hline CC_1086 & Sensory box protein & CATGTTCGCAAGATGTTCC & + & 15.5 & -114 & $0.8 \pm 0.2$ \\
\hline $\mathrm{CC}_{-} 3214$ & $\begin{array}{l}\text { Carbamoyl-phosphate } \\
\text { synthase/carboxyl } \\
\text { transferase }\end{array}$ & CATGTTCCACTTTTGTTCT & + & 17.9 & -103 & $0.6 \pm 0.5$ \\
\hline CC_1665* & $\begin{array}{l}\text { dnaB/replicative DNA } \\
\text { helicase }\end{array}$ & GATGTTCTGTGTATGTTTT & - & 14.5 & -73 & $0.3 \pm 0.1$ \\
\hline CC_2433* & $\begin{array}{l}\text { Conserved hypothetical } \\
\text { protein }\end{array}$ & ATTATTTTCATTATGTTTT & + & 16.5 & -105 & $0.1 \pm 0.0$ \\
\hline
\end{tabular}

${ }^{a}+$ indicates the template strand, and - indicates the complementary strand

${ }^{b}$ The box position is relative to the annotated start codon.

${ }^{c}$ An asterisk indicates a gene that was used in the construction of the model shown in Fig. 2.

teria (19), and all three genes (CC 3238, CC 3237, and CC_3236) are in fact induced in the lex $\bar{A}$ null background. We also observed that imuA, the first gene in the operon devoted to mutagenic DNA repair in $C$. crescentus, is among the most highly expressed in the lex $A$ strain, confirming our previous results (25). Some of the genes identified in the approach have putative functions related to DNA metabolism, such as CC_2272 (encoding an endonuclease III family protein), CC_0382 (tag gene, DNA methyladenine glycosylase I), CC_2332 and CC_1330 (which exhibit a photolyase domain), and CC_3518 (UvrC-like domain). Most of the genes encode proteins of previously uncharacterized function, here determined for the first time to be involved in the proteobacterial DNA damage response. One of the surprises of this study was the finding that $d n a B$ (a replicative helicase) and the ORF CC_2433 (encoding a conserved hypothetical protein) were downregulated in the strain containing the lex $A$ deletion, in spite of containing SOS boxes with significant scores. This is indicative of a positive direct or indirect regulation of these genes by the LexA protein, a feature that is not commonly found in the SOS regulon of other bacteria, and highlights the importance of gene expression data in the validation of in silico predictions.

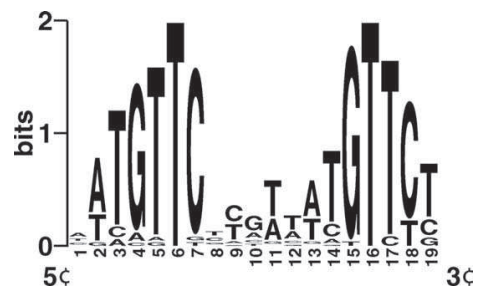

FIG. 2. Caulobacter crescentus LexA binding site model. The sequence logo was generated using the WebLogo program (14).
In our analysis, we did not observe any significant correlation between the box score and the relative expression obtained from the quantitative RT-PCR experiments (Table 2). This is an indication that, at least in $C$. crescentus, the level of repression of the LexA-regulated genes does not directly reflect the similarity of their SOS operator to the consensus pattern. Other factors, like intrinsic promoter strength and the positioning of the operator relative to sigma factor binding sites, are likely to contribute to the final level of induction.

In vivo functionality of the SOS operator. The in silico analysis identified the model shown in Fig. 2 as the potential LexA binding site in $C$. crescentus, in good agreement with previous studies in several alphaproteobacteria (19). A highscore candidate binding site (Table 2; see Fig. S1 in the supplemental material) is present in the promoter region of the imu $A$ gene, the first gene of an operon involved in mutagenic DNA repair in $C$. crescentus (25). In order to determine the role of the identified operator in the regulation of PimuA, we have conducted site-directed mutagenesis in the promoter region previously shown to drive high levels of expression after UV irradiation. We have introduced two base substitutions in the potential LexA binding site, as shown in Fig. 3, creating an operator-constitutive $\left(\mathrm{O}^{c}\right)$ mutant for the $i m u A$ promoter. The activities of both the wild- type and the mutagenized promoters (PimuA and PimuAO ${ }^{c}$ ) were measured in transcriptional fusions with the lac $Z$ gene, both in the wild-type and $\operatorname{lex} A$ strains. As shown before, PimuA is highly UV inducible. Remarkably, the basal levels of transcription of $\mathrm{Pimu} \mathrm{O}^{\mathrm{c}}$ are much higher than those observed for the wild-type promoter ( $\sim 10$-fold), showing that the operator identified in silico contributes significantly to the repression of imuA expression under physiological conditions (Fig. 3). It is also interesting to note that the levels of $\beta$-galactosidase expression achieved with $\mathrm{Pimu} \mathrm{O}^{\mathrm{c}}$ in nonirradiated cells are even higher than those observed when 
PimuA: 5'GAACAAAAGTGGAAC3' PimuAOc: 5'GAACAAAAGTGCGAC3'

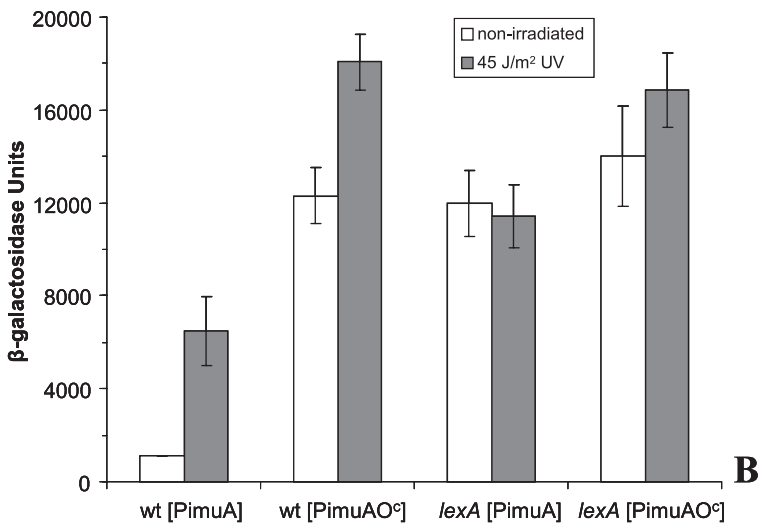

FIG. 3. Site-directed mutagenesis of the $i m u A$ promoter and analysis of promoter activity in $\beta$-galactosidase assays. (A) The SOS box in the promoter of the $i m u A$ gene is shown, with the conserved, directed repeats shown in bold. The underlined bases were altered in $\mathrm{PimuAO}^{\mathrm{c}}$, eliminating the directed repeat. (B) The chart shows the average of three $\beta$-galactosidase assays performed with the wild-type (wt) and lexA strains with plasmids pP3213 and pP3213Oc, containing PimuA and $\mathrm{Pimu} A \mathrm{O}^{\mathrm{c}}$, respectively. Induction of the SOS response was achieved by the irradiation of cells with $45 \mathrm{~J} / \mathrm{m}^{2}$ of UVC.

cells carrying the wild-type promoter fusion are exposed to 45 $\mathrm{J} / \mathrm{m}^{2}$ of UV light. Nonetheless, transcription from Pimu $A \mathrm{O}^{\mathrm{c}}$ is still slightly stimulated by UV light, suggesting that residual binding of the repressor may still occur. These results confirm that the SOS operator identified in silico in this study and previously by others (19) is indeed responsible for the repression of the SOS genes in $C$. crescentus. In the lex $A$ strain, both Pimu $A$ and Pimu $A \mathrm{O}^{\mathrm{c}}$ show similar levels of basal transcriptional activity, which is not significantly modified after UV irradiation of cells.

After the demonstration of the function of the SOS operator in vivo, we determined the positioning of this sequence relative to the RNA polymerase binding sites in the promoters of $i m u A$ and the endonuclease III glycosylase-related gene CC 2272, another tightly SOS-regulated gene (Table 2). For that purpose, 5' RACE experiments were performed to determine the transcriptional start site of these two SOS genes. As shown in Fig. 4, the transcriptional start site for the imu $A$ gene was determined to be located 71 bases upstream from the annotated start codon of this ORF and 23 to 25 bases upstream from the ATG in the case of the CC 2272 gene. In the latter, it was impossible to precisely determine the start site, given that the primer used in the $5^{\prime}$ RACE experiments contains a run of T's (see Material and Methods) and that the 5' RACE products start with the sequence $\mathrm{T}_{(13-20)}$ ATGTTCTCG. Thus, the starting site for the CC 2272 gene can be any of the three bases marked in Fig. 4. Considering these transcriptional start sites, we identified the regions with similarity to the -10 and -35 consensus sequences for the vegetative sigma factor of $C$. crescentus (34). Remarkably, the SOS operator overlaps the transcriptional start site and the end of the -10 region in both promoters, even with the three-base imprecision in mapping the transcriptional start site of the gene CC_2272. The posi-

\begin{abstract}
5' Race CC2272:
AGCCTGTGGACAAACCTCGACGCTGAGCATAATGTTCTTdTTATGTTCTCGCGCGGAGA GGTTCCATGCAGCTGTCCCTAGCCCTGGCCCGGTCACCGCTGGAAAGCGTGCGGGACGC

5' Race imuA:

CAAGCCTTGACTCTCCAGTCCGGGAAGATCAGAACAAAAGTGGAACATGGAGTTGGGAA TGGCCGGATCGCGCGAGGCGCGTCTTGCGGCCCTGAGAGGCCGGATCGCCGCGATGGA GCGGGGACTCGGACTCCGACTCCGGTGCTGTCGTTCGGAGAGCCGTCGATCGACGGGTG

Cnsensus sima 7•: TTGaCS $\mathrm{N}_{(1 \bullet-14)}$ GCtANAWC $\mathrm{N}_{(5-7)}+1$

FIG. 4. Determination of the transcriptional start sites of $i m u A$ and CC_2272. The sequence around the predicted transcriptional start site is shown, with the coding sequence highlighted in bold. The transcriptional start sites are shown inside the black boxes and in italics. The SOS box is shown in gray shading, and the conserved -35 and -10 sequences are underlined. The consensus promoter for the vegetative sigma factor (34) is shown at the bottom.
\end{abstract}

tioning of the operators could clearly impose a block to RNA polymerase access and/or promoter unwinding upon LexA binding, showing that the position of the identified operators is consistent with the proposed function.

\section{DISCUSSION}

In the present work, the SOS regulon of Caulobacter crescentus was elucidated by the combined use of in silico analysis and quantitative RT-PCR assays. We were able to identify 35 genes that are up-regulated in the lex $A$ strain and that are thus part of the SOS regulon in this organism. A previous survey of DNA repair-related genes in $C$. crescentus identified many interesting features of this bacterium concerning the maintenance of genome integrity (35), and this work expanded these studies, revealing genes that are involved in the DNA damage response.

We have confirmed the motif GTTCN $_{7}$ GTTC as the SOS operator in this organism, in good agreement with previous reports (19). In the $i m u A$ promoter, this sequence was shown to be responsible for a high level of repression, as determined by the site-directed mutagenesis experiments. Furthermore, this repression was shown to be mediated by LexA, since the operator is not functional in the lex $A$ strain.

$C$. crescentus displays the core of SOS-regulated genes in proteobacteria, which is comprised of $\operatorname{rec} A, \operatorname{lex} A, s s b, u v r A$, and $r u v C A B(19)$. It is important to highlight that the most induced gene in this analysis was $\operatorname{lex} A$, the negative regulator of the regulon. Among the genes shown to be part of the SOS regulon in this bacterium, some are interesting and reveal potentially new pathways that may be induced by DNA damage.

The CC 2272 gene encodes an endonuclease III family DNA glycosylase, responsible for the removal of pyrimidine adducts other than dimers and (6-4) photoproducts, the most representative of pyrimidine lesions created by UV irradiation (24). Another important gene is CC_0382, which encodes the DNA-methyladenine glycosylase I gene (tag). This protein catalyzes the removal of the cytotoxic lesion 3-methyladenine (3meA), induced by alkylation damage (41). To our knowledge, the induction of these two genes represents the first evidence of base excision repair genes regulated by the SOS response. The case of the tag gene is interesting if we consider that bacteria usually possess two DNA-methyladenine glycosylases, Tag and AlkA. The latter is described as being induced 
by sublethal doses of alkylating agents, while tag is constitutively expressed in E. coli (5). The regulation of tag by the SOS response adds a new layer of complexity in its regulation and in the removal of $3 \mathrm{meA}$ from the genome. Further examination of the SOS regulon in other bacterial species will reveal if this is a specific feature of $C$. crescentus physiology or a more widespread phenomenon.

Some other genes of unknown function, but which are potentially involved in DNA repair activities, were shown to be SOS regulated in C. crescentus. The CC_3518 gene encodes a protein with high similarity to the N-terminal end of UvrC endonucleases. In E. coli, the gene cho ( $y d j Q$ ) encodes a 295amino-acid protein with similarity to the $\mathrm{N}$ terminus of UvrC $(33,43,62)$. Interestingly, the protein encoded by CC_3518, one of the most strongly SOS-upregulated genes in C. crescentus, also bears similarity to UvrC, although it is even smaller than Cho, consisting of only 123 amino acids. A BLAST analysis reveals that CC_3518 orthologs, with similar size, are widespread among bacteria. Another interesting family of genes includes CC_2332 and CC_1330 (35). They are both similar to the radical $S$-adenosylmethionine superfamily of proteins, which includes the $s p l B$ gene of Bacillus subtilis that encodes the spore photoproduct photolyase. Possibly, these genes represent a different class of SOS-regulated bacterial photolyase genes. Interestingly, the Mycobacterium tuberculosis gene Rv2578c encodes a homolog of CC_2332 and CC_1330 and has been shown to be part of the SOS regulon in that organism (16), further supporting a role for these genes in the DNA damage response. CC_2332 is in a putative operon with another SOS-regulated gene, CC_2333, which is related to another base excision repair-related protein, uracil-DNA glycosylase (35).

On the other hand, $d n a B$ and CC_2433 were consistently down-regulated in the $\operatorname{lex} A$ strain, suggesting that they are actually repressed upon SOS induction. For Rhodobacter sphaeroides, LexA has been proposed to both repress and activate transcription of the $\operatorname{rec} A$ promoter (59). It is possible that in these two genes, LexA may act as a transcriptional activator. Since the lexA strain is severely affected in cell division and growth, the down-regulation of these genes might just reflect a pleiotropic effect of this gene disruption. However, it is interesting to note that the operators identified in both promoters are corrupted in the direct repeat, lacking one or both of the GTTC units (Table 2).

The case of $d n a B$ is especially interesting, given that in previous reports it was shown to be damage inducible independently of RecA in E. coli (32); in $C$. crescentus, however, this gene is down-regulated in a LexA-dependent fashion. The implications of this fact are not completely clear. Considering the complex and coordinated cell cycle of $C$. crescentus, it would not be surprising to find a gene involved in replication initiation being repressed in the presence of DNA damage (simulated by the constitutive expression of the SOS-regulated genes in this $\operatorname{lex} A$ background), since it could act as an additional mechanism ensuring that replication initiation would be allowed only after the lesions are removed.

The gene comM (CC_0140), which had already been proposed to be part of the LexA regulon of alphaproteobacteria (19), was also confirmed by this analysis. It was annotated as a $\mathrm{Mg}^{2+}$ chelatase in Brucella suis and Brucella melitensis; thus, this gene could be involved in the regulation of polymerase fidelity synthesis during SOS activation, as has been proposed for members of this class of proteins in E. coli (64). In Haemophilus influenzae, the ComM protein was discovered on the basis of a transformation-deficient mutant that exhibited normal DNA uptake but possessed low transformation and phage recombination efficiencies (27).

Our analysis identified also some genes with known function that have never been associated with the SOS regulon in other organisms. One of these is CC_3225, which encodes a sensory box histidine kinase/response regulator. Two-component signal transduction systems are known to be the major cellular signaling molecules in prokaryotes. They are usually comprised of a sensor histidine kinase and a response regulator that mediates an appropriate cellular response to an endogenous or exogenous signal (46). The CC_2040 gene encodes an ATPdependent RNA helicase, a member of the DEAD/DEAH family. C. crescentus possesses four members of this family of proteins, but only one seems to be LexA-regulated. These proteins are generally energy motors involved in the conformational change of RNAs, and as such, they are involved in many aspects of RNA metabolism, like transcription, ribosome biogenesis, translation, and RNA degradation (28); the term RNA helicase, however, has to be considered carefully, since for the vast majority of proteins, the exact biochemical activity has not been defined yet (57). We also identified the gene CC_3130, responsible for a glutamine synthetase family protein, as being regulated by LexA in $C$. crescentus. This enzyme is involved in nitrogen assimilation through the incorporation of ammonia in bacteria (49). It is still not clear how these genes would be involved in the celullar response to DNA damage, and thus further analyses are needed.

The results also indicated SOS regulation of a large number of hypothetical proteins, some of which did not display significant similarity to any other known protein in the microbial genomes sequenced so far. Representatives of this class of genes are some with highly increased expression in the $\operatorname{lex} A$ mutant, like CC 0627 (the second-most induced gene in the lex $A$ strain [see Table 2]), CC_1927, CC_3356, CC_1531, CC_1532, CC_0383, and the first gene (CC_2879) of a putative operon of two genes. The CC 3467 gene, which encodes a conserved hypothetical protein related to proteins of unknown function in other bacteria, can also be included in this group. Another class of genes controlled by LexA in C. crescentus is that of the putative transcriptional regulators; this analysis identified CC_1054, CC_3036, and CC_3037 belonging to this group. CC 1054 is a member of the $\mathrm{CopG}$ transcriptional repressor family, CC_3036 belongs to the AlgR/AgrA/LytR family of transcriptional regulators, and CC_3037 is a helixturn-helix-containing protein. Therefore, the indirect effects of SOS induction on global gene expression patterns are likely to occur.

Another interesting feature revealed by this work is the potential existence of an SOS-mediated divisional checkpoint in $C$. crescentus. In E. coli, the SulA protein inhibits cell division after SOS induction by blocking FtsZ polymerization (4, 54). As a result of this blockage, lex $A$ knockouts are not viable, unless sulA is also disrupted. In contrast, in Bacillus subtilis, lex $A$ knockouts are viable, although cells do show a filamentous aspect and poor growth; this filamentation is dependent on the 
yne $A$ gene, which is unrelated to sulA (30). The sulA and yneA orthologs are not present in the $C$. crescentus genome (45) or in many other bacterial genomes (data not shown), and it will be of special interest to determine the genes responsible for this lexA-dependent divisional checkpoint in $C$. crescentus.

In total, 37 genes were identified as part of the SOS regulon in $C$. crescentus, including 35 genes that were induced and 2 genes that were repressed. Although the regulons in $E$. coli (13) and $B$. subtilis (2) are substantially bigger, the $C$. crescentus regulon contains more genes than the Pseudomonas aeruginosa (11) and Staphylococcus aureus (12) regulons, which are comprised of 15 and 16 genes, respectively. A table comparing the known SOS regulons of several bacterial species to that of $C$. crescentus is provided (see Table S2 in the supplemental material). Almost all SOS regulons described so far control the rec $A$ and $\operatorname{lex} A$ genes, as well as one or more recombination/ repair functions and one or more $\mathrm{Y}$ family polymerases. We found in this study that $C$. crescentus is not an exception to this rule. However, some exceptions to this fact are known. In the bacteria "Dehalococcoides ethenogenes" (22), Bdellovibrio bacteriovorus (9), a "Magnetococcus" sp. (23), Petrotoga miotherma (38), Acidobacterium capsulatum (39), Deinococcus radiodurans (44), and Geobacter sulfurreducens (29), recA is not regulated by LexA. There are also lex $A$ genes that are not autoregulated, as in Leptospira interrogans (15). The most dramatic situation has been found in Thermotoga maritima, where neither lexA nor rec $A$ is part of the SOS regulon (38); this is not commonly found in bacteria that have not suffered major genome reduction and ended up losing the lexA gene (Chlamydia pneumoniae, Mycoplasma pneumoniae, and Campylobacter jejuni, for example).

In conclusion, this work has further expanded the current knowledge of the prokaryotic responses to DNA damage, revealing a number of new genes which are part of the SOS regulon. These findings are especially relevant in the context of recent efforts focusing on unraveling the SOS response in several different bacteria, since it might play relevant roles in bacterial evolution and the development of antimicrobial resistance $(3,10,11,12,42)$.

\section{ACKNOWLEDGMENTS}

Financial support was obtained from FAPESP (São Paulo, Brazil) and $\mathrm{CNPq}$ (Brasília, Brazil). R.S.G. received a postdoctoral fellowship from FAPESP. R.P.D.R. and R.S.G. received fellowships from FAPESP, and A.C.D.M.P. received a fellowship from CAPES (Brasília, Brazil).

\section{REFERENCES}

1. Abella, M., I. Erill, M. Jara, G. Mazón, S. Campoy, and J. Barbé. 2004 Widespread distribution of a lexA-regulated DNA damage-inducible multiple gene cassette in the Proteobacteria phylum. Mol. Microbiol. 54:212-222.

2. Au, N., E. Kuester-Schoeck, V. Mandava, L. E. Bothwell, S. P. Canny, K. Chachu, S. A. Colavito, S. N. Fuller, E. S. Groban, L. A. Hensley, T. C. O'Brien, A. Shah, J. T. Tierney, L. L. Tomm, T. M. O'Gara, A. I. Goranov, A. D. Grossman, and C. M. Lovett. 2005. Genetic composition of the Bacillus subtilis SOS system. J. Bacteriol. 187:7655-7666.

3. Beaber, J. W., B. Hochhut, and M. K. Waldor. 2004. SOS response promotes horizontal dissemination of antibiotic resistance genes. Nature 427:72-74.

4. Bi, E., and J. Lutkenhaus. 1993. Cell division inhibitors SulA and MinCD prevent formation of the FtsZ ring. J. Bacteriol. 175:1118-1125.

5. Bjelland, S., and E. Seeberg. 1996. Different efficiencies of the Tag and AlkA DNA glycosylases from Escherichia coli in the removal of 3-methyladenine from single-stranded DNA. FEBS Lett. 397:127-129.

6. Reference deleted

7. Reference deleted.
8. Reference deleted.

9. Campoy, S., N. Salvador, P. Cortés, I. Erill, and J. Barbé. 2005. Expression of canonical SOS genes is not under LexA repression in Bdellovibrio bacteriovorus. J. Bacteriol. 187:5367-5375.

0. Cirz, R. T., J. K. Chin, D. R. Andes, V. de Crecy-Lagard, W. A. Craig, and F. E. Romesberg. 2005. Inhibition of mutation and combating the evolution of antibiotic resistance. PLoS Biol. 3:e176.

11. Cirz, R. T., B. M. O'Neill, J. A. Hammond, S. R. Head, and F. E. Romesberg. 2006. Defining the Pseudomonas aeruginosa SOS response and its role in the global response to the antibiotic ciprofloxacin. J. Bacteriol. 188:7101-7110.

12. Cirz, R. T., M. B. Jones, N. A. Gingles, T. D. Minogue, B. Jarrahi, S. N. Peterson, and F. E. Romesberg. 2007. Complete and SOS-mediated response of Staphylococcus aureus to the antibiotic ciprofloxacin. J. Bacteriol. 189: 531-539.

13. Courcelle, J., A. Khodursky, B. Peter, P. O. Brown, and P. C. Hanawalt. 2001. Comparative gene expression profiles following UV exposure in wildtype and SOS-deficient Escherichia coli. Genetics 158:41-64.

14. Crooks, G. E., G. Hon, J. M. Chandonia, and S. E. Brenner. 2004. WebLogo: a sequence logo generator. Genome Res. 14:1188-1190.

15. Cuñé, J., P. Cullen, G. Mazón, S. Campoy, B. Adler, and J. Barbé. 2005. The Leptospira interrogans lexA gene is not autoregulated. J. Bacteriol. 187: 5841-5845.

16. Davis, E. O., E. M. Dullaghan, and L. Rand. 2002. Definition of the mycobacterial SOS box and use to identify LexA-regulated genes in Mycobacterium tuberculosis. J. Bacteriol. 184:3287-3295.

17. Ely, B. 1991. Genetics of Caulobacter crescentus. Methods Enzymol. 204: 372-384.

18. Erill, I., M. Escribano, S. Campoy, and J. Barbé. 2003. In silico analysis reveals substantial variability in the gene contents of the gamma proteobacteria LexA-regulon. Bioinformatics 19:2225-2236.

19. Erill, I., M. Jara, N. Salvador, M. Escribano, S. Campoy, and J. Barbé. 2004. Differences in LexA regulon structure among Proteobacteria through in vivo assisted comparative genomics. Nucleic Acids Res. 32:6617-6626.

20. Evinger, M., and N. Agabian. 1977. Envelope-associated nucleoid from Caulobacter crescentus stalked and swarmer cells. J. Bacteriol. 132:294-301.

21. Fernández de Henestrosa, A., T. Ogi, S. Aoyagi, D. Chafin, J. J. Hayes, H. Ohmori, and R. Woodgate. 2000. Identification of additional genes belonging to the LexA regulon in Escherichia coli. Mol. Microbiol. 35:1560-1572.

22. Fernández de Henestrosa, A. R., J. Cuñé, I. Erill, J. K. Magnuson, and J. Barbé. 2002. A green nonsulfur bacterium, Dehalococcoides ethenogenes, with the LexA binding sequence found in gram-positive organisms. J. Bacteriol. 184:6073-6080.

23. Fernández de Henestrosa, A. R., J. Cuñé, G. Mazón, B. L. Dubbels, D. A Bazylinski, and J. Barbé. 2003. Characterization of a new LexA binding motif in the marine magnetotactic bacterium strain MC-1. J. Bacteriol. 185:4471-4482.

24. Friedberg, E. C., G. C. Walker, W. Siede, R. D. Wood, R. A. Schultz, and T. Ellenberger. 2006. DNA repair and mutagenesis. ASM Press, Washington, DC

25. Galhardo, R. S., R. P. Rocha, M. V. Marques, and C. F. M. Menck. 2005. An SOS-regulated operon involved in damage-inducible mutagenesis in Caulobacter crescentus. Nucleic Acids Res. 33:2603-2614.

26. Gober, J. W., and L. Shapiro. 1992. A developmentally regulated Caulobacter flagellar promoter is activated by $3^{\prime}$ enhancer and IHF binding elements. Mol. Biol. Cell 3:913-916.

27. Gwinn, M. L., R. Ramanathan, H. O. Smith, and J.-F. Tomb. 1998. A new transformation-deficient mutant of Haemophilus influenzae Rd with normal DNA uptake. J. Bacteriol. 180:746-748.

28. Jankowsky, E., and M. E. Fairman. 2007. RNA helicases—one fold for many functions. Curr. Opin. Struct. Biol. 17:316-324.

29. Jara, M., C. Núñez, S. Campoy, A. R. Fernández de Henestrosa, D. Lovley, and J. Barbé. 2003. Geobacter sulfurreducens has two autoregulated lexA genes whose products do not bind the $r e c A$ promoter: differing responses of lexA and recA to DNA damage. J. Bacteriol. 185:2493-2502.

30. Kawai, Y., S. Moriya, and N. Ogasawara. 2003. Identification of a protein, YneA, responsible for cell division suppression during the SOS response in Bacillus subtilis. Mol. Microbiol. 47:1113-1222.

31. Khill, P. P., and R. D. Camerini-Otero. 2002. Over 1000 genes are involved in the DNA damage response in Escherichia coli. Mol. Microbiol. 44:89-105.

32. Kleinsteuber, S., and A. Quiñones. 1995. Expression of the dnaB gene of Escherichia coli is inducible by replication-blocking DNA damage in a recAindependent manner. Mol. Gen. Genet. 248:695-702.

33. Lomba, M. R., A. T. Vasconcelos, A. B. Pacheco, and D. F. de Almeida. 1997. Identification of yebG as a DNA damage-inducible Escherichia coli gene. FEMS Microbiol. Lett. 156:119-122.

34. Malakooti, J., and B. Ely. 1995. Principal sigma subunit of the Caulobacte crescentus RNA polymerase. J. Bacteriol. 177:6854-6860.

35. Martins-Pinheiro, M., R. C. Marques, and C. F. M. Menck. 2007. Genome analysis of DNA repair genes in the alpha proteobacterium Caulobacter crescentus. BMC Microbiol. 12:7-17.

36. Matic, I., F. Taddei, and M. Radman. 2004. Survival versus maintenance of 
genetic stability: a conflict of priorities during stress. Res. Microbiol. 155: 337-341.

37. Reference deleted

38. Mazón, G., S. Campoy, A. R. Fernández de Henetrosa, and J. Barbé. 2006. Insights into the LexA regulon of Thermotogales. Antonie van Leeuwenhoek 90:123-137.

39. Mazón, G., S. Campoy, I. Erill, and J. Barbé. 2006. Identification of the Acidobacterium capsulatum LexA box reveals a lateral acquisition of the Alphaproteobacteria lexA gene. Microbiology 152:1109-1118.

40. McKenzie, G. J., R. S. Harris, P. L. Lee, and S. M. Rosenberg. 2000. The SOS response regulates adaptive mutation. Proc. Natl. Acad. Sci. USA 97:6646-6651.

41. Metz, A. H., T. Hollis, and B. F. Eichman. 2007. DNA damage recognition and repair by 3-methyladenine DNA glycosylase I (TAG). EMBO J. 26: 2411-2420.

42. Miller, C., L. E. Thomsem, C. Gaggero, R. Mosseri, H. Ingmer, and S. N. Cohen. 2004. SOS response induction by $\beta$-lactams and bacterial defense against antibiotic lethality. Science 305:1629-1631.

43. Moolenaar, G. F., S. van Rossum-Fikkert, M. van Kesteren, and N. Goosen. 2002. Cho, a second endonuclease involved in Escherichia coli nucleotide excision repair. Proc. Natl. Acad. Sci. USA 99:1467-1472.

44. Narumi, I., K. Satoh, M. Kikuchi, T. Funayama, T. Yanagisawa, Y. Kobayashi, H. Watanabe, and K. Yamamoto. 2001. The LexA protein from Deinococcus radiodurans is not involved in RecA induction following $\gamma$ irradiation. J. Bacteriol. 183:6951-6956.

45. Nierman, W. C., T. V. Feldblyum, M. T. Laub, I. T. Paulsen, K. E. Nelson, J. A. Eisen, J. F. Heidelberg, M. R. Alley, N. Ohta, J. R. Maddock, I. Potocka, W. C. Nelson, A. Newton, C. Stephens, N. D. Phadke, B. Ely, R. T. DeBoy, R. J. Dodson, A. S. Durkin, M. L. Gwinn, D. H. Haft, J. F. Kolonay, J. Smit, M. B. Craven, H. Khouri, J. Shetty, K. Berry, T. Utterback, K. Tran, A. Wolf, J. Vamathevan, M. Ermolaeva, O. White, S. L. Salzberg, J. C. Venter, L. Shapiro, and C. M. Fraser. 2001. Complete genome sequence of Caulobacter crescentus. Proc. Natl. Acad. Sci. USA 98:4136-4141.

46. Pirrung, M. C. 1999. Histidine kinases and two-component signal transduction systems. Chem. Biol. 6:167-175.

47. Pfaff, M. W. 2001. A new mathematical model for relative quantification in real-time RT-PCR. Nucleic Acids Res. 29:e45.

48. Quillardet, P., M.-A. Rouffaud, and P. Bouige. 2003. DNA array analysis of gene expression in response to UV irradiation in Escherichia coli. Res. Microbiol. 154:559-572.
49. Reitzer, L. 2003. Nitrogen assimilation and global regulation in Escherichia coli. Annu. Rev. Microbiol. 57:155-176.

50. Reference deleted.

51. Reference deleted.

52. Roberts, R. C., C. Toochinda, M. Avedissian, R. L. Baldini, S. L. Gomes, and L. Shapiro. 1996. Identification of a Caulobacter crescentus operon encoding $h c r A$, involved in negatively regulating heat-inducible transcription and the chaperone gene grpE. J. Bacteriol. 178:1829-1841.

53. Sassanfar, M., and J. W. Roberts. 1990. Nature of the SOS-inducing signal in Escherichia coli. The involvement of DNA replication. J. Mol. Biol. 212: 79-96.

54. Schoemaker, J. M., R. C. Gayda, and A. Markovitz. 1984. Regulation of cell division in Escherichia coli: SOS induction and cellular localization of the SulA protein, a key to lon-associated filamentation and death. J. Bacteriol. 158:551-561.

55. Stormo, G. D. 2000. DNA binding sites: representation and discovery. Bioinformatics 16:16-23.

56. Reference deleted.

57. Tanner, N. K., and P. Linder. 2001. DExD/H RNA helicases: from generic motors to specific dissociation functions. Mol. Cell 8:251-262.

58. Reference deleted.

59. Tapias, A. S. Fernández, J. C. Alonso, and J. Barbé, 2002. Rhodobacter sphaeroides LexA has dual activity: optimizing and repressing rec $A$ gene transcription. Nucleic Acids Res. 30:1539-1546.

60. Thompson, W., E. C. Rouchka, and C. E. Lawrence. 2003. Gibbs Recursive Sampler: finding transcription factor binding sites. Nucleic Acids Res. 31: 3580-3585.

61. Tsai, J. W., and M. R. Alley. 2000. Proteolysis of the McpA chemoreceptor does not require the Caulobacter major chemotaxis operon. J. Bacteriol 182:504-507.

62. Van Houten, B., J. A. Eisen, and P. C. Hanawalt. 2002. A cut above: discovery of an alternative excision repair pathway in bacteria. Proc. Natl. Acad. Sci. USA 99:2581-2583.

63. Walker, G. C. 1984. Mutagenesis and inducible responses to deoxyribonucleic acid damage in Escherichia coli. Microbiol. Rev. 48:60-93.

64. Yang, L., K. Arora, W. A. Beard, S. H. Wilson, and T. Schlick. 2004. Critical role of magnesium ions in DNA polymerase $\beta$ s closing and active site assembly. J. Am. Chem. Soc. 126:8441-8453. 